
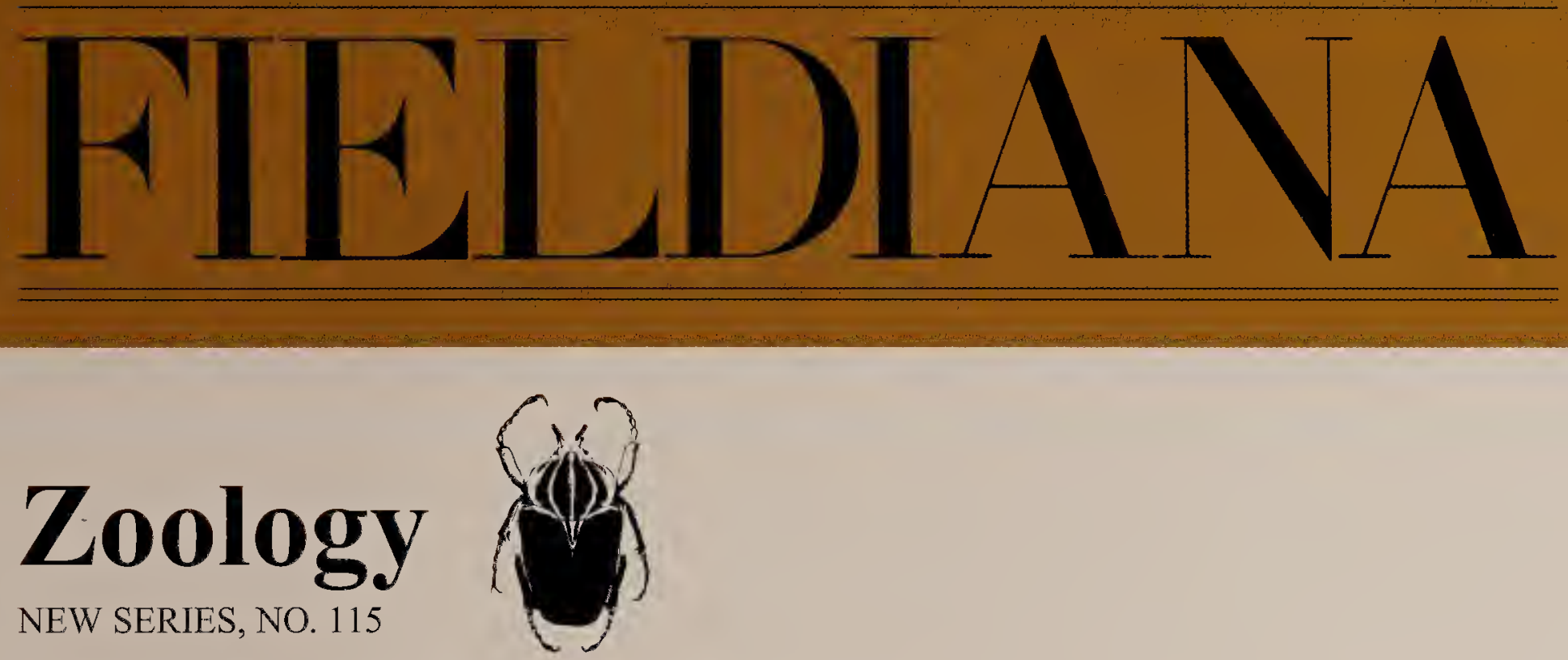

The Fishes of Will County, Illinois

Philip W. Willink

Francis M. Veraldi

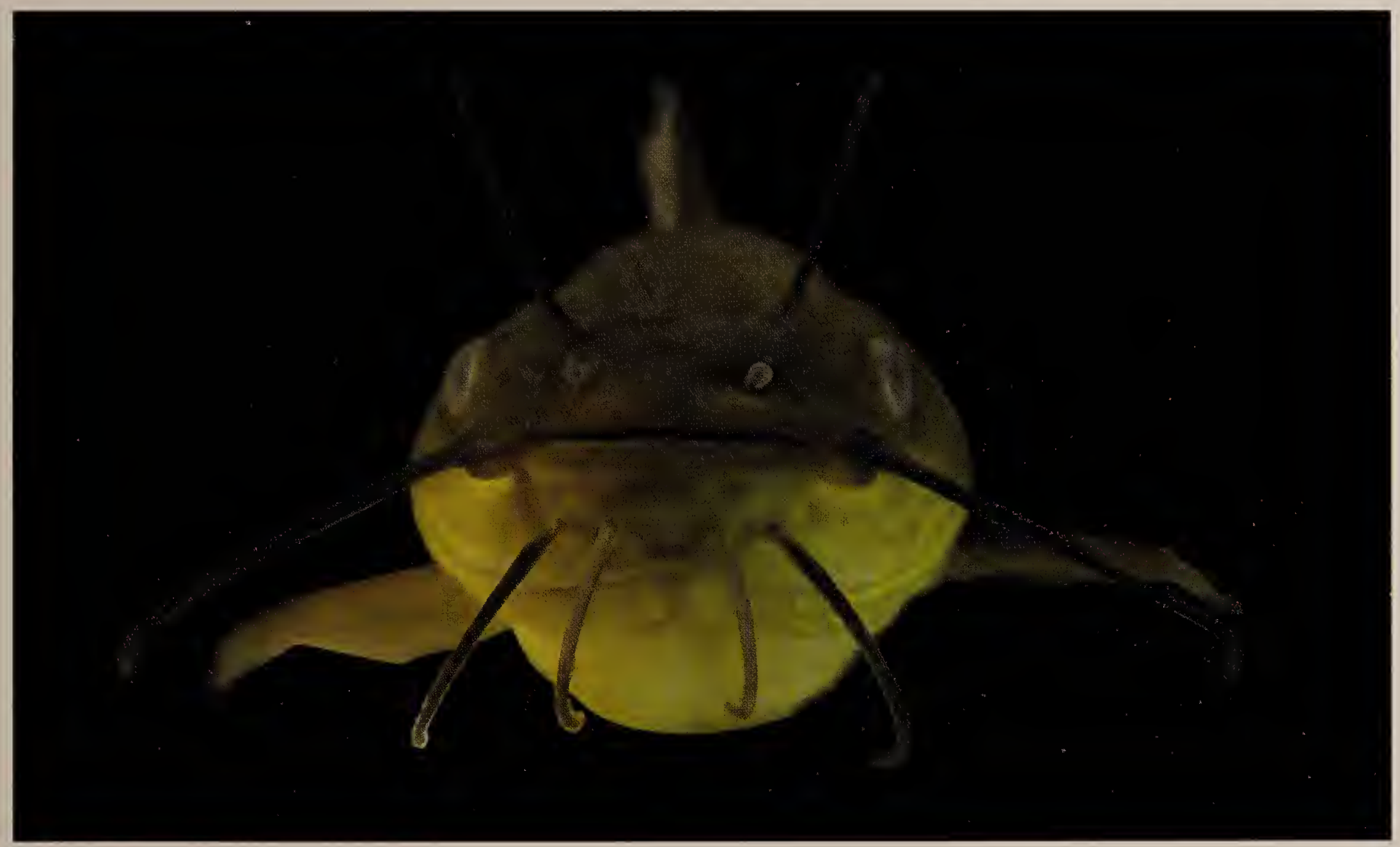

February 24, 2009

Publication 1551

PUBLISHED BY FIELD MUSEUM OF NATURAL HISTORY 


\section{$\overline{\text { FIELIDINIA }}$}

\section{Mission}

Fieldiana is a peer-reviewed monographic series published by the Field Museum of Natural History. Fieldiana focuses on midlength monographs and scientific papers pertaining to collections and research at The Field Museum. The four series pertain to subject matter in the fields of Anthropology, Botany, Geology, and Zoology.

\section{Eligibility}

Field Museum curators, research associates, and full-time scientific professional staff may submit papers for consideration.

Edited volumes pertaining to Field Museum collections may also be submitted for consideration under a subsidy arrangement. The submission and peer review of these chaptered volumes should be arranged well in advance with the managing scientific editor and the appropriate associate editor.

\section{Submission Procedures}

Submission procedures are detailed in a separate document called "SUBMISSIONS PROCEDURES" available on the Fieldiana web site:

(http://www.fieldmuseum.org/research_collections/fieldiana/) under the Author's page. All manuscripts should be submitted to the managing scientific editor.

\section{Editorial Contributors:}

\section{Managing Scientific Editor}

Harold K. Voris (hvoris@fieldmuseum.org)

\section{Editorial Assistant}

Chris Jones (cjones2@fieldmuseum.org)

\section{Anthropology}

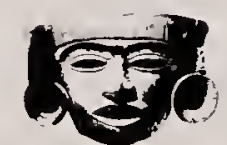

\section{Co-Associate Editors}

Jonathan Haas (jhaas@fieldmuseum.org)

Gary Feinman (gfeinman@fieldmuseum.org)

\section{Geology}

Associate editor

John Bolt (jbolt@fieldmuseum.org)

\section{Acting Editorial Coordinator}

Peter Lowther (plowther@fieldmuseum.org)

\section{Illustration Editor}

Lisa Kanellos (lkanellos@fieldmuseum.org)

\section{Botany}

\section{Associate Editor}

Sabine Huhndorf (shuhndorf@fieldmuseum.org)

\section{Zoology}

Associate Editor

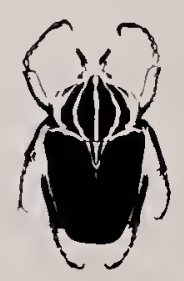

Janet Voight (jvoight@fieldmuseum.org) 


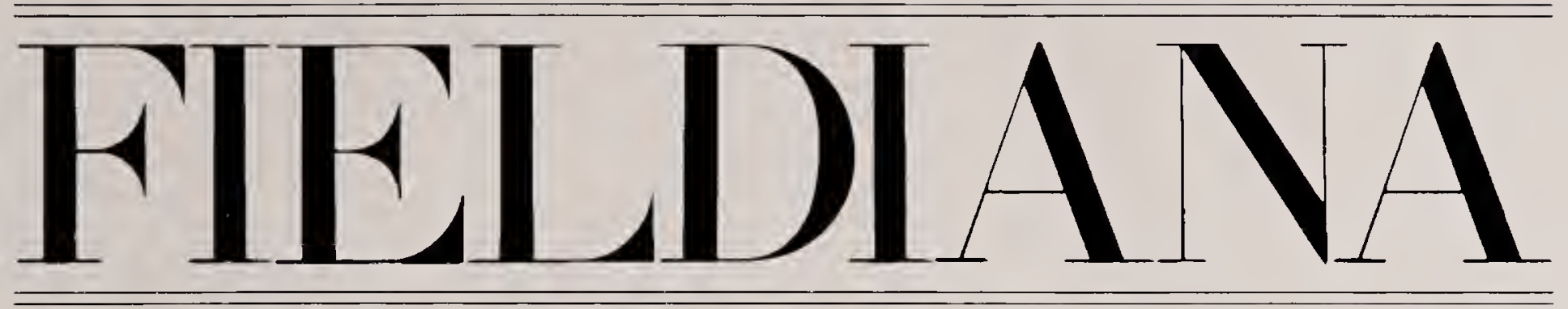

\section{Zoology}

NEW SERIES, NO. 115

\section{The Fishes of Will County, Illinois}

Philip W. Willink

Department of Zoology

The Field Museum

1400 South Lake Shore Drive

Chicago, Illinois 60605-2496

U.S. A. ${ }^{\prime}$

${ }^{I}$ E-mail:pwillink@fieldmuseum.org
Francis M. Veraldi

Environmental Planning Section

U.S. Army Corps of Engineers

111 North Canal Street, Suite 600

Chicago, Illinois 60606-7206

U.S.A.

Accepted September 14, 2008

Published February 24, 2009

Publication 1551 
(c) 2009 Field Museum of Natural History ISSN 0015-0754

PRINTED IN THE UNITED STATES OF AMERICA 


\section{Table of Contents}

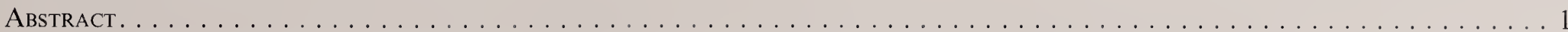

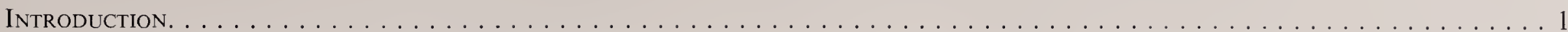

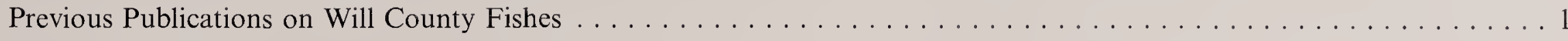

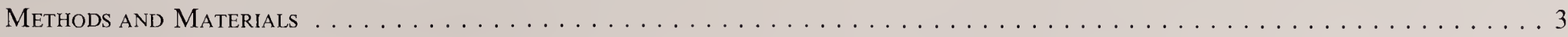

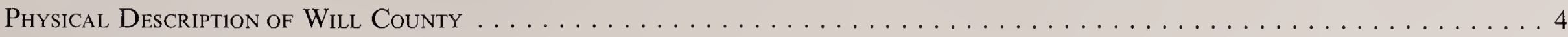

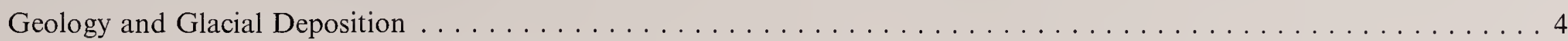

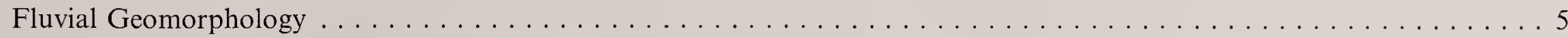

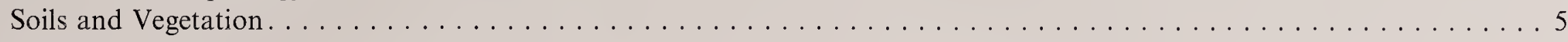

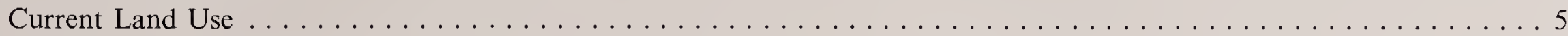

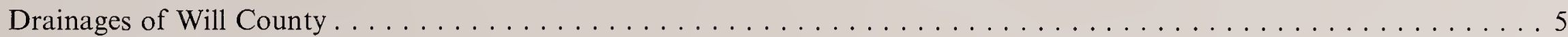

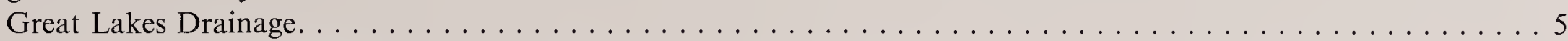

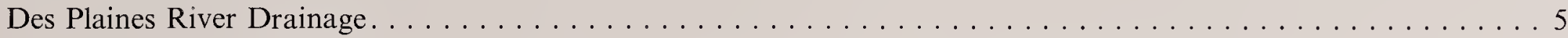

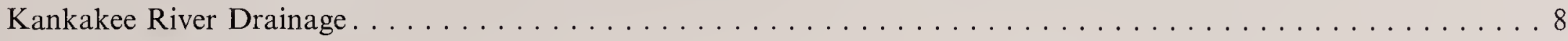

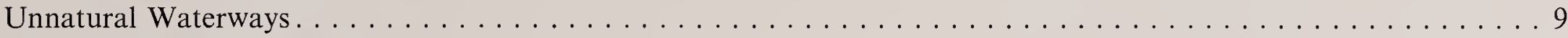

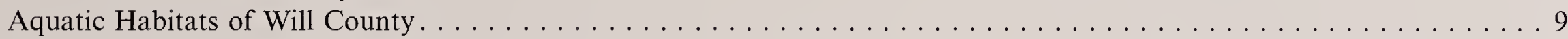

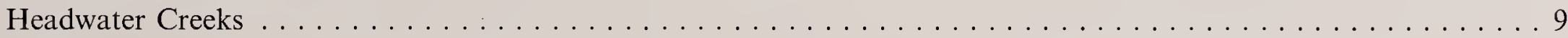

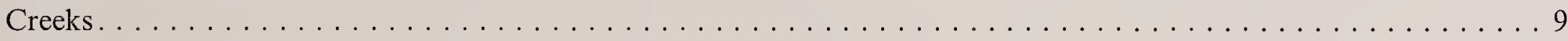

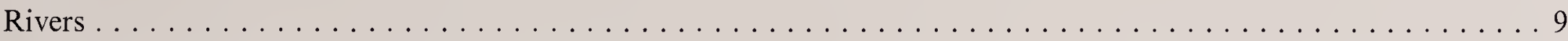

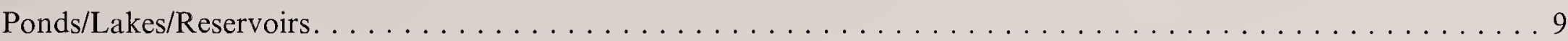

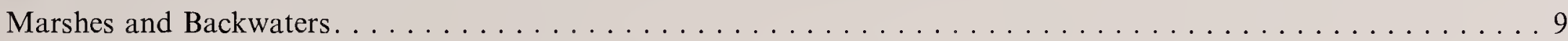

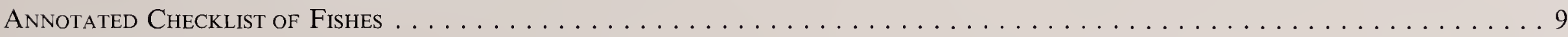

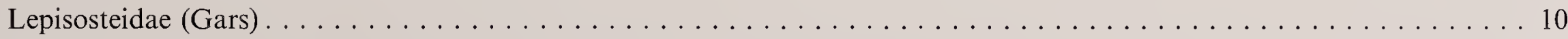

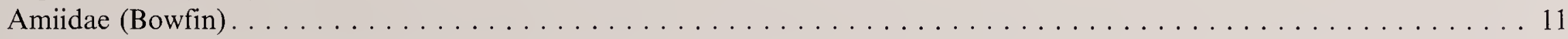

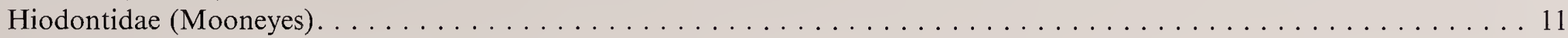

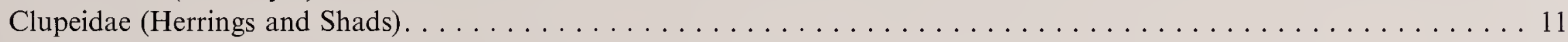

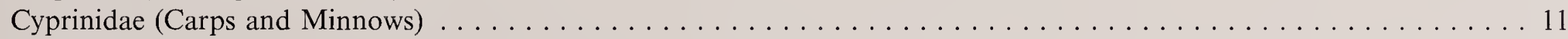

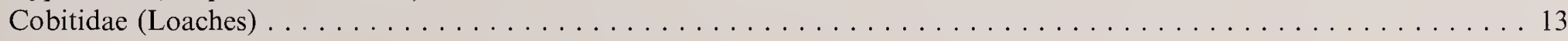

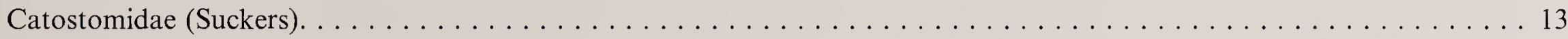

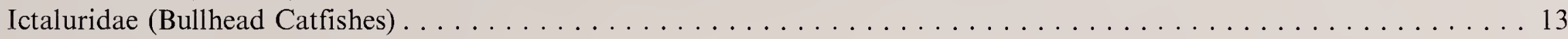

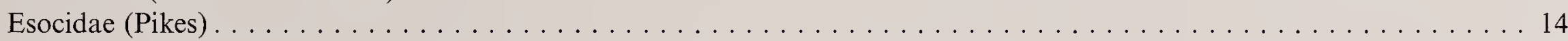

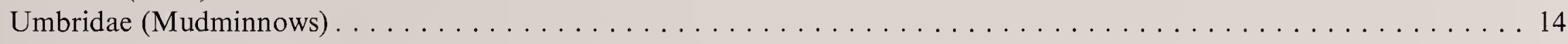

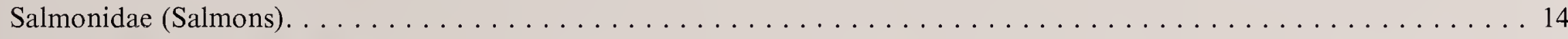

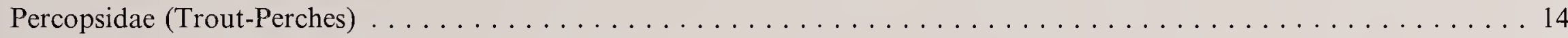

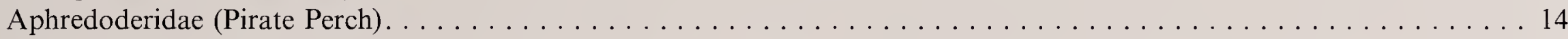

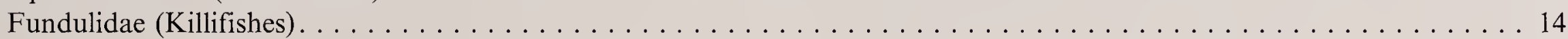

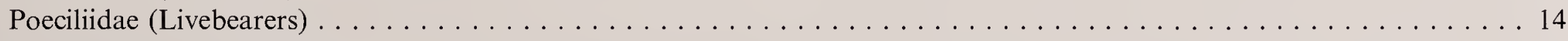

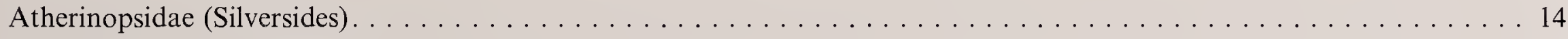

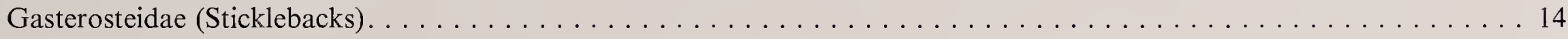

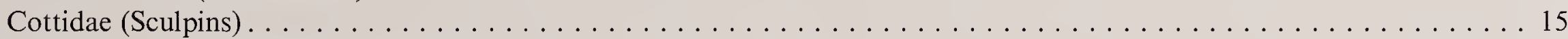

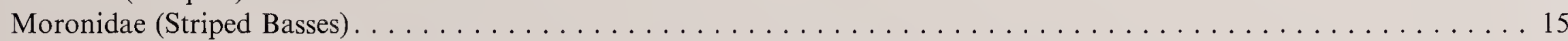

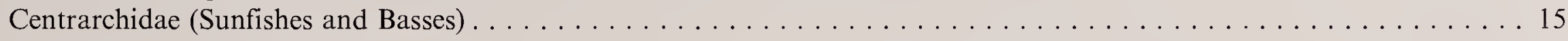

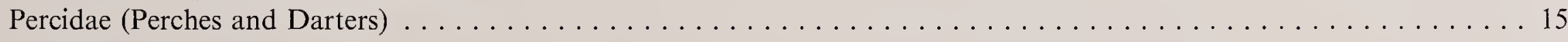

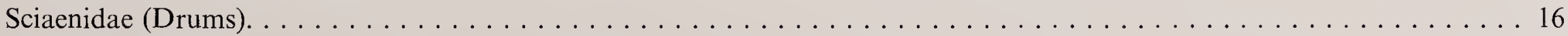

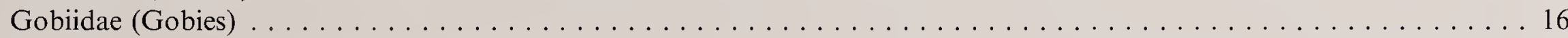

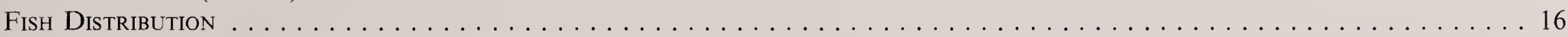

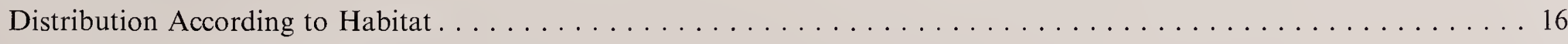

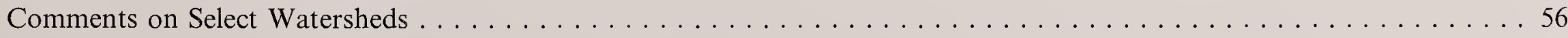

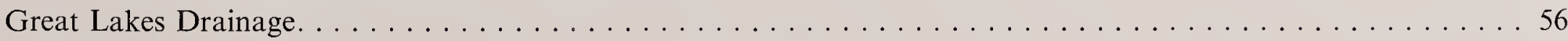

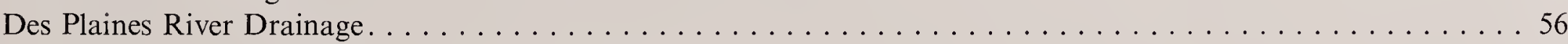

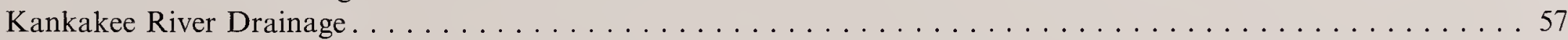

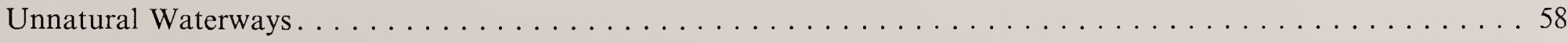

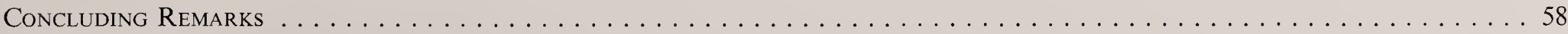

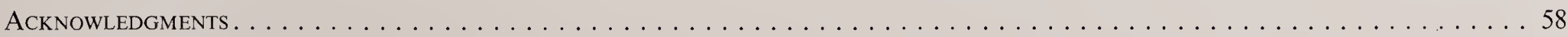

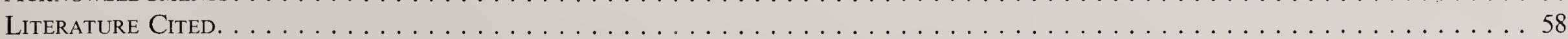

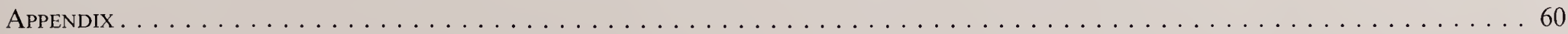




\section{List of Illustrations}

1. Will County in relation to Illinois, Indiana, and major river systems. $\ldots \ldots \ldots \ldots$

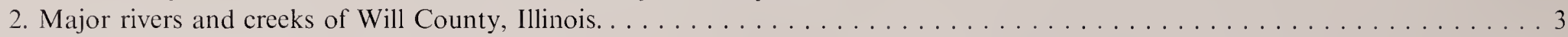

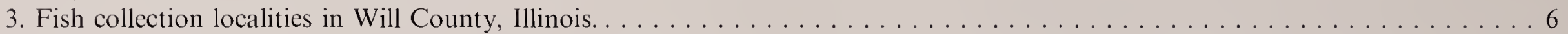

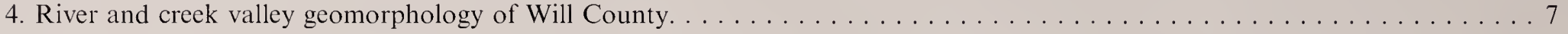

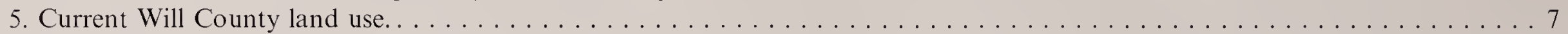

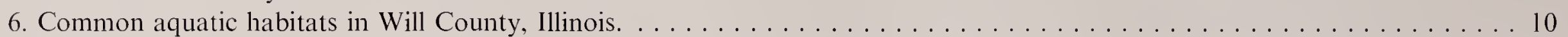

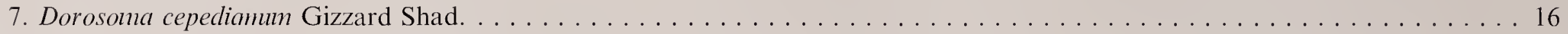

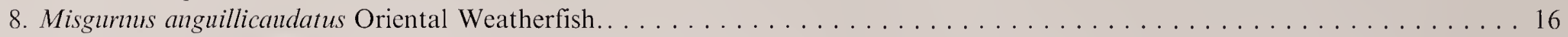

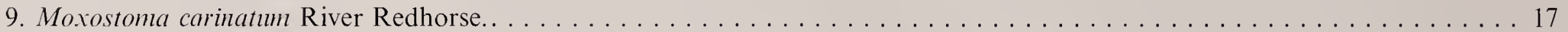

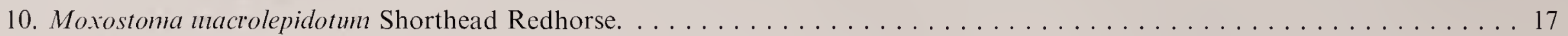

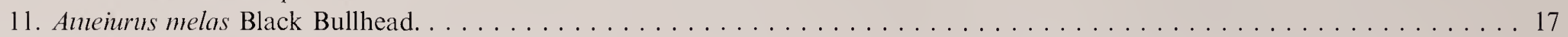

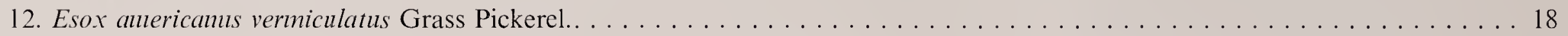

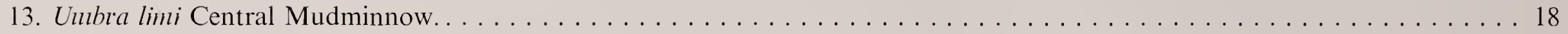

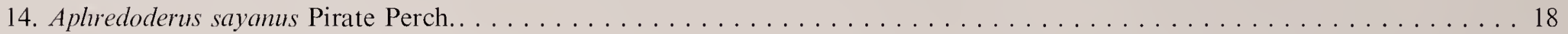

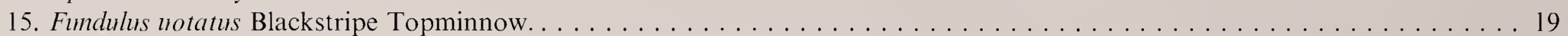

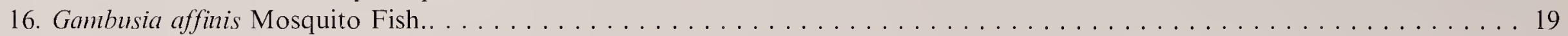

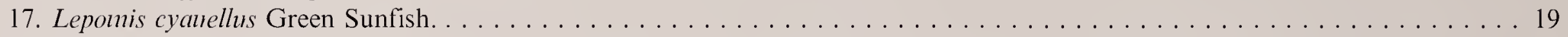

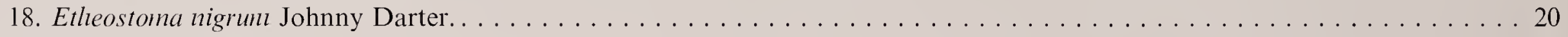

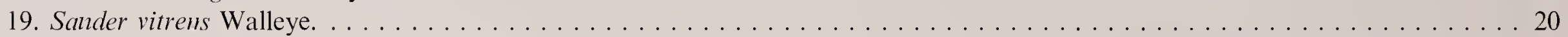

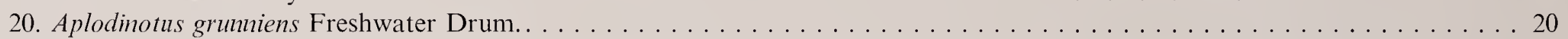

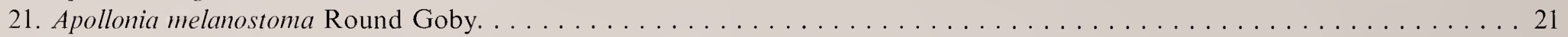

22. Distribution of Lepisosteus osseus (Longnose Gar) and Lepisosteus platostomus (Shortnose Gar). . . . . . . . . . . . . . . . . . 21

23. Distribution of Amia calva (Bowfin), Hiodon alosoides (Goldeye), and Hiodon tergisus (Mooneye).. . . . . . . . . . . . . . . . 22

24. Distribution of Alosa clirysocllloris (Skipjack Herring) and Dorosoma petenense (Threadfin Shad) . . . . . . . . . . . . . . . 22

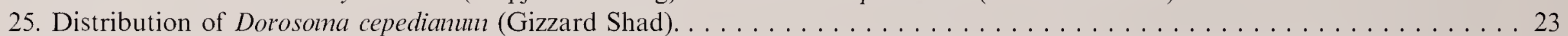

26. Distribution of Canpostoma anomalum (Central Stoneroller) and Campostoma oligolepis (Largescale Stoneroller).......... . 23

27. Distribution of Carassius auratus (Goldfish) . . . . . . . . . . . . . . . . . . . . . . . . . . . . . . 24

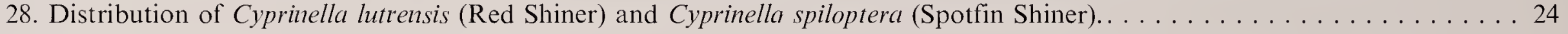

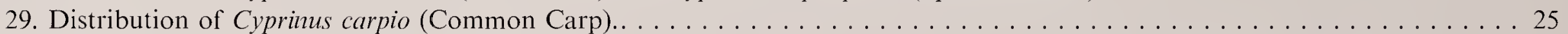

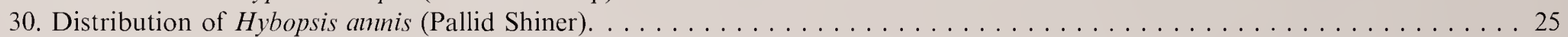

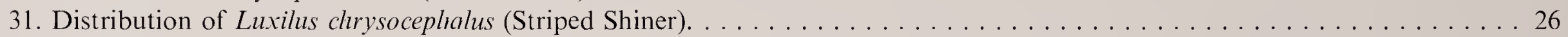

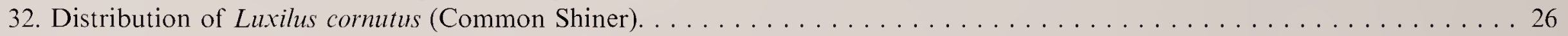

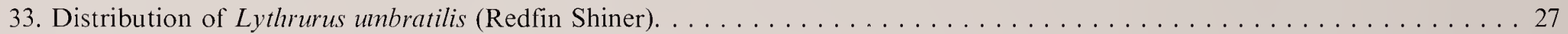

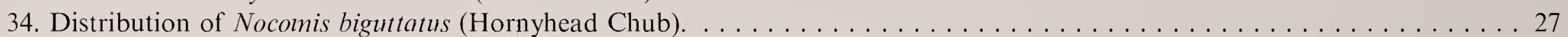

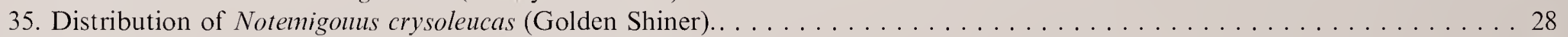

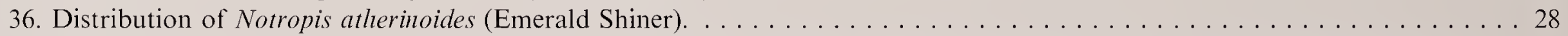

37. Distribution of Notropis blennius (River Shiner), Notropis boops (Bigeye Shiner), and Notropis buccatus (Silverjaw Minnow). . 29

38. Distribution of Notropis bucluanani (Ghost Shiner), Notropis claclybaeus (Ironcolor Shiner), and Notropis dorsalis (Bigmouth Shiner).

39. Distribution of Notropis leterolepis (Blacknose Shiner), Notropis lundsonius (Spottail Shiner), and Notropis rubellus (Rosyface Shiner)..

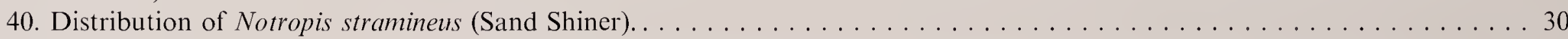

41. Distribution of Notropis texalnus (Weed Shiner) and Notropis volucellus (Mimic Shiner). . . . . . . . . . . . . . . . . 31

42. Distribution of Opsopoeodus emiliae (Pugnose Minnow), Pllenacobius mirabilis (Suckermouth Minnow), and Plioxinus

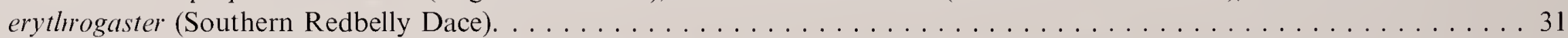

43. Distribution of Pimephales notatus (Bluntnose Minnow) . . . . . . . . . . . . . . . . . . . . . . . . 32

44. Distribution of Pilneplales promelas (Fathead Minnow) and Pimeplales vigilax (Bullhead Minnow). . . . . . . . . . . . . . . 32

45. Distribution of Rlinichtlys atratulus (Blacknose Dace) and Scardinius erytlirophthalmus (Rudd). . . . . . . . . . . . . . 33

46. Distribution of Semotilus atromaculatus (Creek Chub) and Misgurnus anguillicaudatus (Oriental Weatherfish). . . . . . . . 33

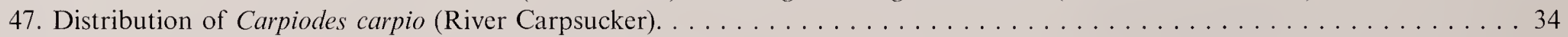

48. Distribution of Carpiodes cyprinus (Quillback) and Carpiodes velifer (Highfin Carpsucker) . . . . . . . . . . . . . . . . 34

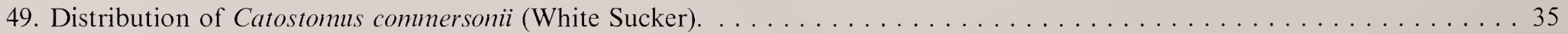

50. Distribution of Erimyzon claviformis (Western Creek Chubsucker) and Hypenteliun nigricans (Northern Hogsucker). . . . . 35

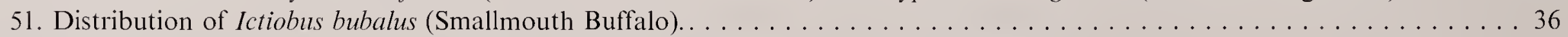

52. Distribution of Ictiobus cyprinellus (Bigmouth Buffalo) and Ictiobus niger (Black Buffalo). . . . . . . . . . . . . . . . . 36

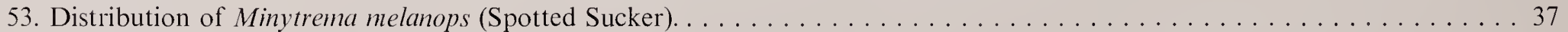

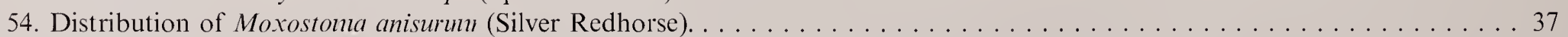

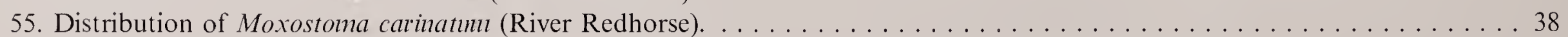

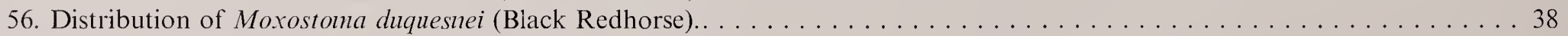

57. Distribution of Moxostoma erytltrurum (Golden Redhorse) . . . . . . . . . . . . . . . . . . . . . . . . . . . 39

58. Distribution of Moxostoma macrolepidotum (Shorthead Redhorse). . . . . . . . . . . . . . . . . . . . . . . . . 39 
59. Distribution of Ameiurns melas (Black Bullhead).. . . . . . . . . . . . . . . . . . . . . . . 40

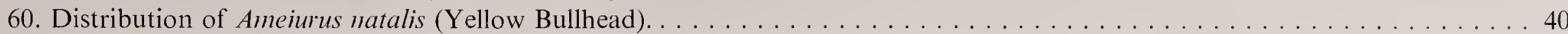

61. Distribution of Ameiurus nebulosus (Brown Bullhead) and Ictalurus punctatus (Channel Catfish) . . . . . . . . . . . . . . . 41

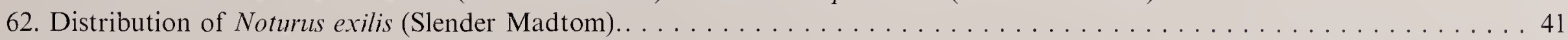

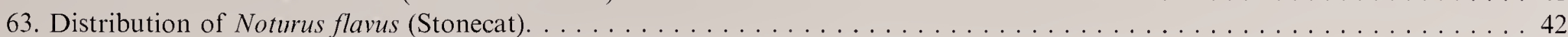

64. Distribution of Noturus gyrinus (Tadpole Madtom) and Noturus nocturnus (Freckled Madtom) . . . . . . . . . . . . . . . 42

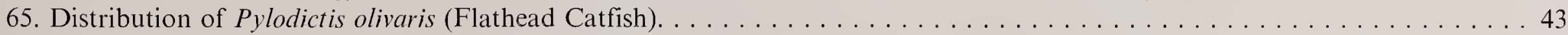

66. Distribution of Esox americanus vermiculatus (Grass Pickerel) and Esox lucius (Northern Pike). . . . . . . . . . . . . . . 43

67. Distribution of Unbra limi (Central Mudminnow) and Oncorlynchus mykiss (Rainbow Trout). . . . . . . . . . . . . . . . 44

68. Distribution of Percopsis omiscomaycus (Trout-Perch), Aplredoderus sayamus (Pirate Perch), Fundulus dispar (Starhead

Topminnow), and Fundulus notatus (Blackstripe Topminnow). . . . . . . . . . . . . . . . . . . . . 44

69. Distribution of Gambusia affinis (Mosquito Fish), Labidestles sicculus (Brook Silverside), Gasterosteus aculeatus (Threespine

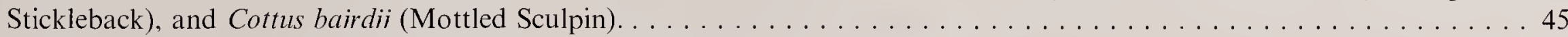

70. Distribution of Morone antericana (White Perch) and Morone chrysops (White Bass). . . . . . . . . . . . . . . . . 45

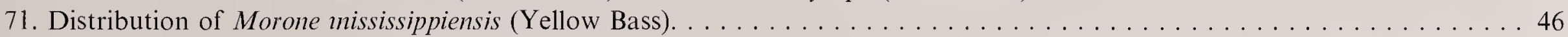

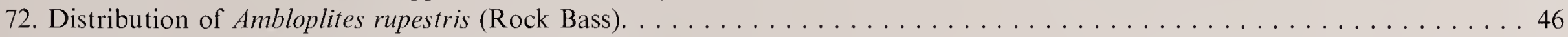

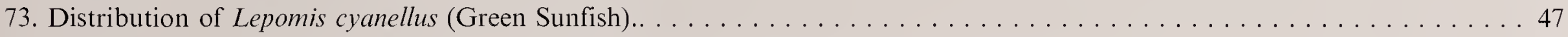

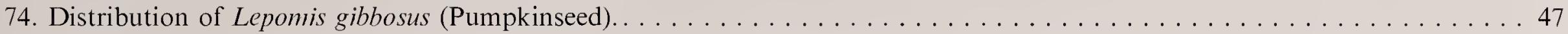

75. Distribution of Lepomis gulosus (Warmouth) and Lepomis humilis (Orangespotted Sunfish) . . . . . . . . . . . . . . . . . 48

76. Distribution of Lepomis macrochirus (Bluegill) and Leponis microlophus (Redear Sunfish). . . . . . . . . . . . . . . . . 48

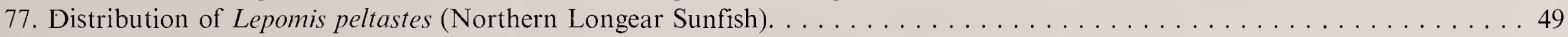

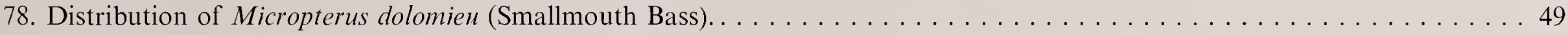

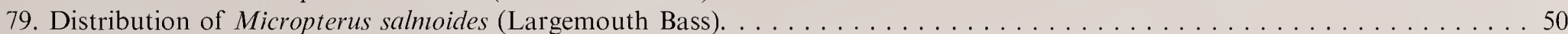

80. Distribution of Pon

81. Distribution of Ammocrypta clara (Western Sand Darter), Etheostonia caeruleum (Rainbow Darter), and Etheostoma exile

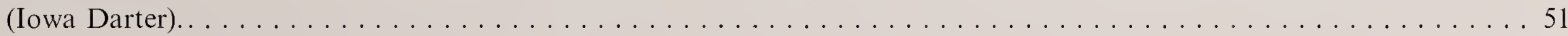

82. Distribution of Etlieostoma flabellare (Fantail Darter) and Etleostoma microperca (Least Darter). . . . . . . . . . . . . . 51

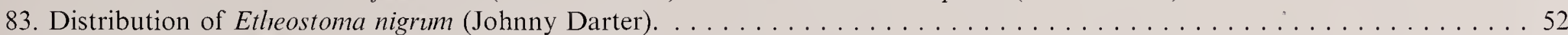

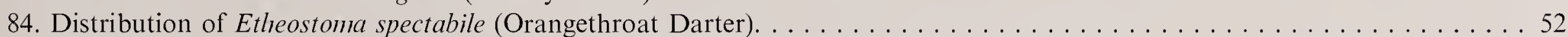

85. Distribution of Etlieostoma zonale (Banded Darter) and Perca flavescens (Yellow Perch). . . . . . . . . . . . . . . . 53

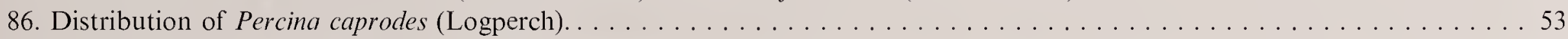

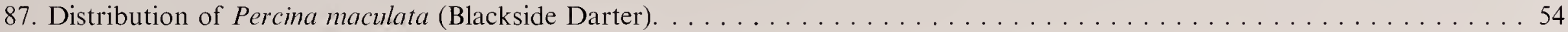

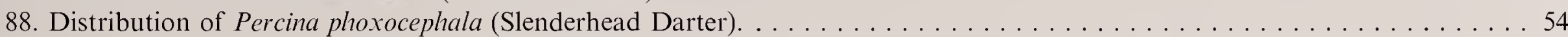

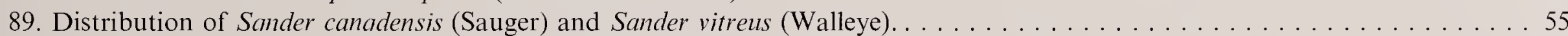

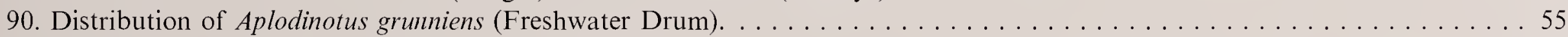

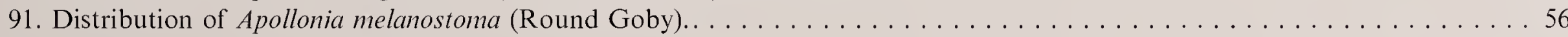

\section{List of Tables}

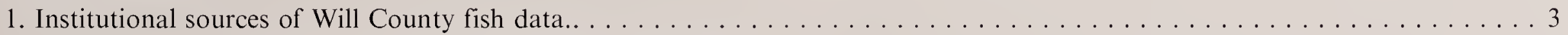

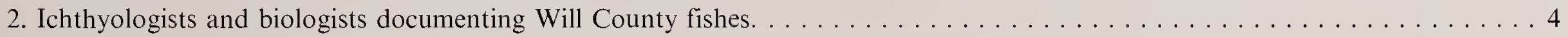

3. Will County land use in hectares, acres, square miles, and percent of aerial coverage.. . . . . . . . . . . . . . 6 



\title{
The Fishes of Will County, Illinois
}

\author{
Philip W. Willink and Francis M. Veraldi
}

\begin{abstract}
A total of 112 fish species has been recorded in Will County over the past 107 years; six species are endangered or threatened in Illinois, and 11 species are nonnative. River and creek ecosystems are the predominant fish habitat within the county. Each watershed has its own individual story. For example, Exline Slough fishes represent what would have been found in regional prairie sloughs and wetlands prior to conversion of natural lands for agriculture. Some creeks, such as Plum Creek, hold an above-average diversity of fishes but are isolated by dams and environmental degradation. If the fishes in these creeks are eliminated, they would not return because of limited opportunities for recolonization. Riparian wetlands along the Des Plaines and Kankakee rivers serve as nurseries for juvenile fishes. Hickory Creek is one of the most studied creeks in the Midwest, but unfortunately loss in biodiversity is what has been documented. Jackson Creek is reminiscent of Hickory Creek historically. Hopefully it will not suffer the same fate. The greatest threat to Will County fishes is urban sprawl from the city of Chicago and its associated habitat degradation. Not only does physical alteration of habitat and water quality pose a threat to native biodiversity, but biological pressures from nonnative species introductions do as well. Populations of the Round Goby Apollonia melanostoma and Oriental Weatherfish Misgurnus anguillicaudatus are established and growing. The Silver Carp Hypophthalmichtlyys molitrix and Bighead Carp Hypophthalmichthys nobilis are anticipated to colonize the larger rivers sometime in the next few years. All is not bad news. Water quality in the Des Plaines River appears to be improving as evidenced by the recent collection of a Freckled Madtom Noturus nocturnus for the first time in over 100 years. Large populations of environmentally sensitive redhorses (Moxostoma spp.) live in the Kankakee River, as does the endangered Pallid Shiner Hybopsis amnis. A variety of quality aquatic habitats in Will County deserve management and protection.
\end{abstract}

\section{Introduction}

Will County fishes have been observed for 107 years, starting in 1901 when Wright, Caton and Howard made two collections from the DuPage River and one from Lily Cache Creek (specimens in the Illinois Natural History Survey collection). This long period of observation has offered an opportunity to evaluate fish faunal changes, first from conversion of natural lands to agriculture and now agriculture to urban development. Located 19 kilometers (12 miles) southwest of Chicago, Illinois (Fig. 1), Will County continues to change as the region's population increases. Hence, it is critical to accurately document the local biodiversity. This information is necessary to identify areas of high diversity and help individuals and organizations make informed decisions regarding scientific studies, management, and conservation of Will County aquatic ecosystems (Fig. 2).

This publication's goal is to present an annotated list of fish species that have been scientifically documented with voucher specimens or reliable reports within Will County over the past century. Dot maps depicting distributions are included. Information on watersheds and habitats is provided because these factors influence fish distributions. This publication does not answer every question about Will County fishes. One could write a separate book on each individual species and each particular drainage. Rather, it is our hope that this publication will provide the context within which future questions can be asked.

\section{Previous Publications on Will County Fishes}

This publication is the most comprehensive analysis of fish distributions within Will County to date, but it is not the only reference. Perhaps the first description is from the $1830 \mathrm{~s}$ (Greenberg, 2003, p. 17): "Hickory Creek was a well behaved stream which never failed to furnish abundant water for cattle farmers and the mills, some of which operated year round. It was a well-defined body of water lasting the whole year. It was well stocked with fish of the pickerel and pike species, with bullhead and catfish." It is a rather vague description, but it does show that water and fishes were important to people at the time and how fish diversity and abundance have declined.

The first scientific publication was probably by Nelson in 1878. His localities were sometimes vague, and it is not always possible to determine which species he was referring to because names have changed. But it does give us insight into what the region was like in the 19th century before major development occurred. This was followed by Meek and Hildebrand (1910), who reviewed the fishes then known to live within 50 miles of Chicago. They included locality information for each species. Some of these localities were within Will County, most notably Hickory Creek.

Shelford (1911) studied a variety of creeks in the Chicago region, including Hickory Creek in Will County. Based on these studies, he formulated his theory of physical creek succession along with its associated succession of fish assemblages. These 


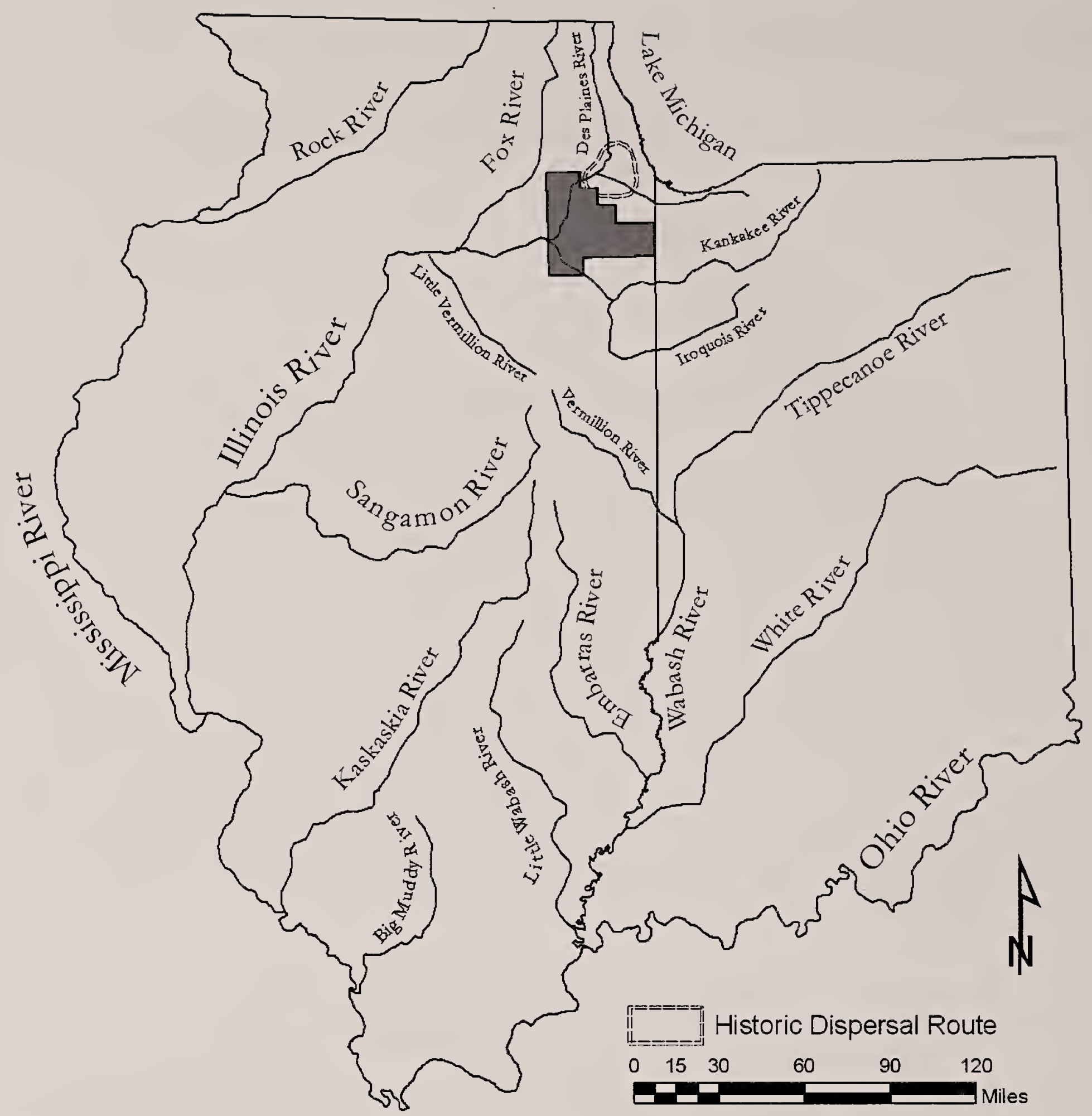

Fig. 1. Will County (shaded gray) in relation to Illinois, Indiana and major river systems. The double-dotted line represents a significant point in North American biogeography, the nexus of the Great Lakes and Mississippi River basins.

ideas were further developed in his 1913 book on animal communities in temperate America. Shelford (1913) included a photo of Hickory Creek in New Lenox. One of Shelford's original localities (rock outcrop near New Lenox) was revisited in 1974 by Molling and Casey (1975). They found a significantly lower biodiversity and attributed the loss to droughts, floods, housing developments, and farm fertilizers.

Woods (1959) wrote about the physical aspects of Hickory Creek and the ecology of the fishes therein. He also lamented the changes he saw from development and pollution. His prediction for the future of Hickory Creek was very bleak. Bland (1976) described some of these changes in more detail and expounded on the long history of collecting in the creek, exhorting people to change.

Hickory Creek was the focus of another study by Dorkin (1980), who extensively reviewed the fishes, both past and present. He also found significant changes in the fish fauna and attributed this to constructional activities (channelization, housing projects, and so on) and the subsequent loss of wetlands.
The latter half of the 20th century saw an increase in papers documenting the fishes of northeastern Illinois. Although they were not explicitly on Will County, they did contain relevant information. For example, the Metropolitan Sanitary District of Greater Chicago (now the Metropolitan Water Reclamation District of Greater Chicago) surveyed creeks and rivers throughout northeastern Illinois to assess water quality. This study collected fishes from 48 localities in Will County (Dennison, 1978). Retzer and Batten (2005) created a checklist of fishes for northeastern Illinois based on Illinois Natural History Survey collections and partially on past (Dennison, 1978) and recent Metropolitan Water Reclamation Distriet of Greater Chicago collections. Smith's The Fishes of Illinois (1979) never explicitly mentions Will County, but the dot maps reveal which species are present.

From 1977 to 1982, Bruner and Resetar (2001) extensively sampled Hickory Creek. Although the results of this study have not been formally published, the specimens were deposited in The Field Museum. They concluded that the 


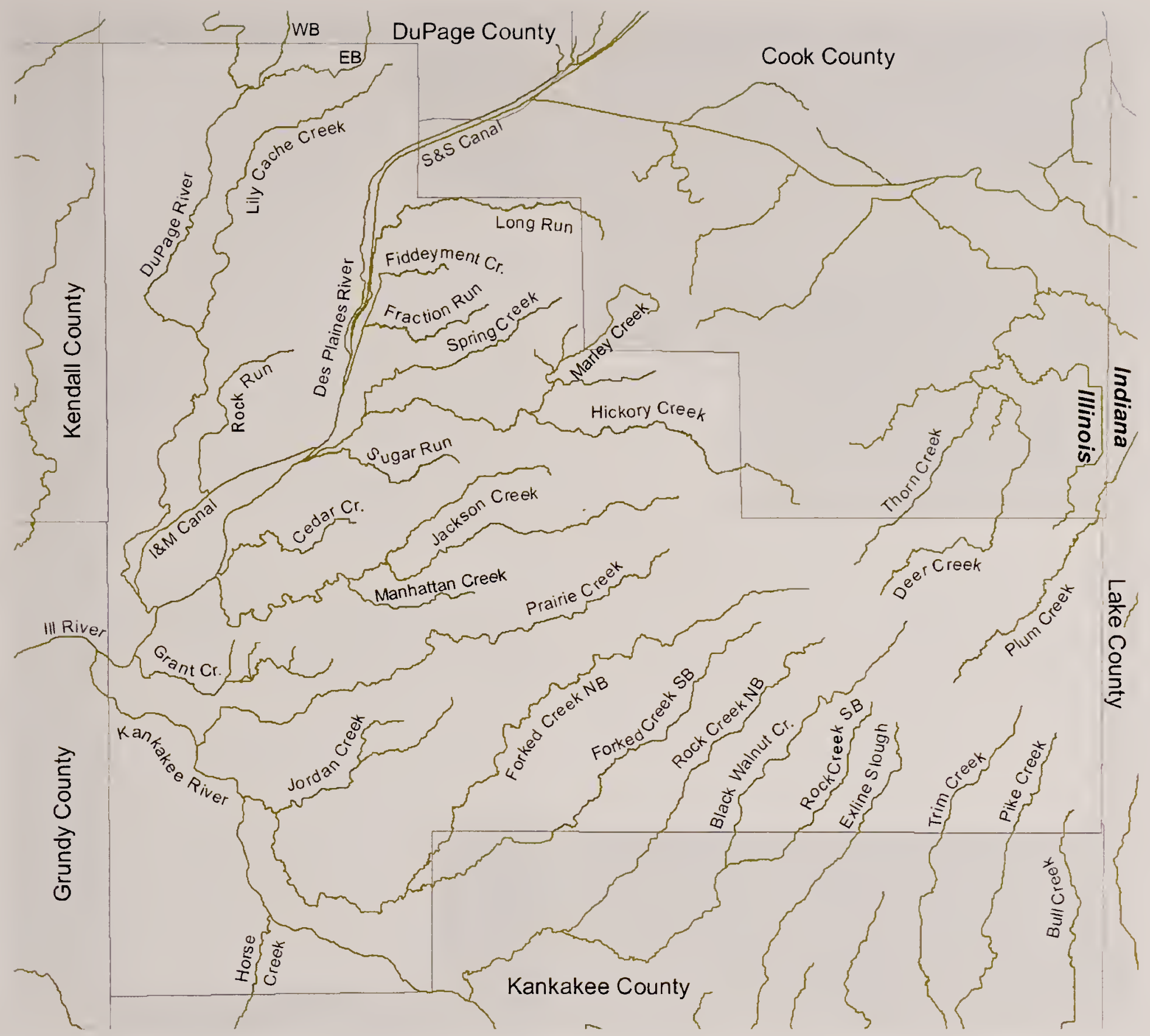

F1G. 2. Major rivers and creeks of Will County, Illinois. S\&S Canal $=$ Chicago Sanitary and Ship Canal, I\&M Canal $=$ Illinois and Michigan Canal, Ill River = Illinois River, EB = East Branch, NB = North Branch, SB = South Branch, WB = West Branch.

number of species has not changed over time; rather, invasive species replaced sensitive species.

Greenberg (2003) wrote a report on Hickory Creek but from a different perspective. Instead of strictly scientific, he reviewed the natural history, people, and past and present conservation activities within the Hickory Creek watershed. This larger context is important in understanding the events and changes that are taking place in the region.

The Illinois Department of Natural Resources routinely samples set localities within Will County and publishes reports on their findings (e.g., Rung, 1996, 1997; Miller, 1998, 1999, 2000, 2002, 2004; Rung \& Pescitelli, 2007). This is but a sample of Will County publications.

\section{Methods and Materials}

Historical data of fish occurrence localities were obtained from fish collections at The Field Museum of Natural History (FMNH), Illinois Natural History Survey, and Southern Illinois University-Carbondale. Unvouchered data were obtained from the Illinois Environmental Protection Agency, Governors State University, and annual basin surveys conducted by the Illinois Department of Natural Resources (Table 1). At least 66 ichthyologists and biologists (Table 2) made a total of 638 collections in Will County from 1901 to 2007,10 having no date associated with them (Fig. 3).

TABLE 1. Institutional sources of Will County fish data. Number of collections per decade is indicated. Institutional abbreviations are as follows: Field Museum of Natural History (FMNH), Illinois Natural History Survey (INHS), Southern Illinois University-Carbondale (SIUC), Illinois Department of Natural Resources (IDNR), Illinois Environmental Protection Agency (IEPA), and Governors State University (GSU).

\begin{tabular}{crrccccc}
\hline Decade & Total & FNNH & INHS & SIUC & IDNR & IEPA & GSU \\
\hline $1901-1909$ & 7 & 4 & 3 & & & & \\
$1910-1919$ & 3 & 3 & & & & & \\
$1920-1929$ & 12 & 12 & & & & & \\
$1930-1939$ & 8 & 8 & & & & & \\
$1940-1949$ & 4 & 4 & & & & & \\
$1950-1959$ & 34 & 30 & 4 & & & 2 & \\
$1960-1969$ & 31 & 3 & 26 & & 5 & & 14 \\
$1970-1979$ & 115 & 83 & 22 & 5 & 45 & & \\
$1980-1989$ & 120 & 19 & 40 & 2 & 45 \\
$1990-1999$ & 106 & & 70 & 11 & 25 & & \\
$2000-2007$ & 188 & 111 & 30 & 14 & 33 & & \\
\hline
\end{tabular}


TABLE 2. Semichronological listing of ichthyologists and biologists who have contributed to documenting Will County fishes.

\begin{tabular}{|c|c|}
\hline Collector(s) & Collection date(s) \\
\hline Howard, Caton and Wright & 1901 \\
\hline C. L. Dewey & 1907 \\
\hline C. M. Barber & 1908 \\
\hline V. E. Shelford & 1909 \\
\hline C. L. Hubbs & 1917,1919 \\
\hline A. C. Weed & 1923 \\
\hline H. Shoemaker & $1936,1937,1938$ \\
\hline L. P. Woods & $1941,1950,1954,1955$ \\
\hline Bradbury & $1950,1954,1955$ \\
\hline R. Inger & 1953,1964 \\
\hline P. W. Smith & $1959,1962,1978$ \\
\hline $\begin{array}{l}\text { R. W. Larimore, W. C. } \\
\text { Starrett, and A. W. Fritz }\end{array}$ & 1959 \\
\hline M. Duever & 1961,1962 \\
\hline D. J. Daleske & 1961 \\
\hline M. E. Braasch & 1962 \\
\hline B. Muench & 1963,1964 \\
\hline P. Vidal & $1964,1967,1970$ \\
\hline L. Berestiansky & 1967 \\
\hline G. J. Tichacek & 1967 \\
\hline G. Zebrun & 1968 \\
\hline $\begin{array}{l}\text { D. Ellis, L. Bernand, and T. } \\
\text { Smith }\end{array}$ & 1971 \\
\hline S. King & 1973 \\
\hline S. G. Dennison & 1973,1976 \\
\hline J. Mendelson & $1974,1990,1994$ \\
\hline B. M. Burr & 1975 \\
\hline M. Sule & 1977,1979 \\
\hline J. C. Bruner & $1977,1978,1980,1982,1983$ \\
\hline A. Resetar & 1978,1980 \\
\hline L. M. Page & $\begin{array}{l}1978,1982,1984,1987,1990,1998 \\
\quad 1999,2000\end{array}$ \\
\hline D. D. Myrick & 1979 \\
\hline K. Leslie & 1980,1989 \\
\hline T. S. Kelly & 1981,1984 \\
\hline K. S. Cummings & $1984,1993,1996$ \\
\hline P. A. Ceas & $1987,1989,1990$ \\
\hline M. J. Wetzel & 1987,1990 \\
\hline T. J. Kwak & 1987 \\
\hline J. T. Peterson & 1987,1990 \\
\hline T. P. Simon & 1988,1989 \\
\hline G. L. Seegert & $1988,1989,1990,1992,1993,1994,1995$ \\
\hline M. A. Morris & 1988 \\
\hline M. E. Retzer & $1990,1997,1998,1999$ \\
\hline T. Bowzer & 1991 \\
\hline B. Kuhl & 1992 \\
\hline C. A. Taylor & 1995,1996 \\
\hline D. Mauger & 1995 \\
\hline R. Rung & $1995,1997,1998,2000,2001,2005$ \\
\hline T. G. Anton & 1995 \\
\hline D. Robson & 1996 \\
\hline S. Pescitelli & $1997,1998,1999,2000,2001,2005$ \\
\hline E. Hammer & 1997,2000 \\
\hline J. H. Knouft & 1998,1999 \\
\hline R. E. DeWalt & 1998 \\
\hline R. Miller & 1998, 1999, 2000, 2002, 2004 \\
\hline T. J. Near & 1999 \\
\hline S. J. Herrington & 1999 \\
\hline J. Steinmetz & 1999,2000 \\
\hline F. M. Veraldi & $2000,2001,2002,2003,2004,2005,2007$ \\
\hline R. Steinberg & 2001 \\
\hline S. Burns & 2001 \\
\hline P. W. Willink & $2004,2005,2007$ \\
\hline
\end{tabular}

Fishes were collected over the past 107 years through various methods that included seining, netting, electrofishing, dipnetting, and angling. Seining, which involves two or more people pulling a net through the water, was the most common method, especially in the early 1900s. Electrofishing began in the mid-20th century and is now widely used. Improvements of equipment and techniques over time have facilitated the capture of elusive fishes and increased surveys of the more difficult-to-reach habitats. Our knowledge of richness, abundance, and distribution of fishes has increased as a result.

Most fish assemblage data collected and preserved concerning Will County is qualitative in nature. Often, ichthyologists and naturalists are simply interested in species occurrence at a particular site and only record the presence of a fish species through a written account or by preserving and depositing a voucher specimen in a museum collection. Quantitative data may be found in specific academic studies (university libraries) or from the Illinois Department of Natural Resources basin surveys that emphasize repeated collections at the same sites on a timely basis to monitor riverine health. These quantitative surveys usually record details such as the relative abundance of species, biomass, specific meristics of certain fish species, and so on.

\section{Physical Description of Will County}

\section{Geology and Glacial Deposition}

Rivers and creeks flow over a variety of substrates in Will County, including bedrock, boulder, cobble, gravel, sand, silts, muck, and clay hardpan. These are derived from the geologic and glacial formations that make up the landscape.

The underlying bedrock is Silurian dolomite formed around 420 million years ago when seas covered the region (Frankie \& Nelson, 2003). The bedrock is generally covered by soil but is exposed by downcutting erosion of several creeks and rivers. Examples include sections of the Des Plaines River, DuPage River, Kankakee River, Forked Creek, Prairie Creek, Jackson Creek, and Hickory Creek (Willman, 1971).

The next several hundred million years of geology in Will County is largely lost because of the actions of erosion. Not until the Pleistocene (1.6 million years ago) is there once again significant deposition. During this epoch, glaciers repeatedly covered and withdrew from the region. Most of the evidence of the older glaciers was erased by subsequent glaciers. Soils were deposited, but it is unclear exactly how. Hence, the most recognizable geological formations in Will County are of the most recent glaciation, the Wisconsinan. This episode started around 25,000 years ago, and the last glacier retreated from Will County around 13,500 years ago. During this time, the region was covered by a couple hundred meters of ice of the Lake Michigan Lobe (Frankie \& Nelson, 2003).

Approximately 15,500 years ago, as the ice was melting and glaciers still covered much of the region, Will County experienced a cataclysmic event known as the Kankakee Torrent. A tremendous amount of glacial meltwater was released in a short amount of time from the glacial Saginaw Lobe in the state of Michigan. This flood followed the presentday course of the Kankakee River, scouring everything in its path, including the southern section of Will County (Wiggers, 1997; Frankie \& Nelson, 2003). For a while after the flood, Lake Wauponsee was formed because floodwaters were impounded by hills and moraines (Willman, 1971; Frankie \& Nelson, 2003). After the floodwaters subsided, the level land became a large wetland known as the Kankakee Marsh, which lasted until agricultural practices drained it in the late 1800 s 
and early 1900s (Greenberg, 2002). Only small vestiges of the marsh remain today.

The most dominant modern glacial feature is the Valparaiso Moraine. It bisects Will County from its southeastern corner to central-northern border. Its elevation forms the drainage divide between the Great Lakes basin and the Mississippi River basin (Figs. 2, 4). Smaller morainal deposits can be found amidst the Valparaiso Moraine.

As the glaciers continued to melt, Lake Chicago formed in the location of present-day Lake Michigan. Because glaciers still existed to the north and east and formed a barrier to water flow, waters from Lake Chicago flowed west into the Mississippi basin through the Chicago Outlet. The scouring and erosion from the Chicago Outlet formed the present-day Des Plaines River valley. This downcutting occurred intermittently as lake levels rose and fell until around 4,000 years ago. At this time an eastward-flowing channel formed in eastern Michigan, lake water levels in the region dropped, the Chicago Outlet dried up, and the modern-day Great Lakes were created (Willman, 1971; Wiggers, 1997).

Following the retreat of the glaciers, fishes recolonized the aquatic habitats of Will County. Most species came from refugia in the Mississippi basin. Some migrated from the north and/or east through proto-Great Lakes connections (Hubbs \& Lagler, 2004).

\section{Fluvial Geomorphology}

Fluvial geomorphic features are landforms that were created by the erosional and depositional processes of rivers. Figure 4 shows how the creeks and rivers in Will County have influenced topography after the glaciers retreated 13,500 years ago. Rivers flowing across the landscape generally increase in size and merge with other rivers. The network of rivers formed is a drainage system that is dendritic in Will County because of the regional topography and underlying geology. Rivers and creeks are conduits not only of water but also of sediment that the water entrains from working the land. As the water flows, it mobilizes sediment from the channel, banks, and floodplain and deposits them downstream. The rate and amount of sediment transport depends on the availability of sediment, particle size, and creek discharge (Brooks et al., 1991). One of the most evident instances of this is where a bank erodes on one side of the creek and a bar forms on the exact opposite side. This process is called cut-and-fill alluviation, and without it the diverse habitat mosaic of the floodplain and river channel would not exist.

\section{Soils and Vegetation}

Soils and vegetation may be considered as the stabilizers of the riverine ecosystem. Soils and vegetation regulate parameters such as water quality, water quantity, erosion rates, habitat, and nutrients. As rainwater falls into a creek's catchment, vegetation, soil, and associated organic matter can absorb great amounts of water and then slowly release it in to the creek or release the water back into the atmosphere. The soil and organic matter can also absorb what would be chemical pollutants to a creek system, such as phosphorus and organic compounds. Vegetation also plays a major role in stabilization of creek banks. Erosion is a completely natural riverine process; however, removal of vegetation or changes in vegetation type within the creek corridor can dramatically increase erosion rates. Vegetation, such as that found in a creekside marsh or riparian zone, directly provide structure for creek fishes and other riverine organisms. Higher elevation areas in Will County were historically covered by forests or savannas, mid-elevation areas were covered by prairies and meadows, and low-elevation areas adjacent to rivers were covered by marshes or forests (Sullivan, 2003).

\section{Current Land Use}

The native vegetation mosaic that existed before the 1700 s has been severely impacted in Will County. A homogenized landscape of agriculture and urbanization now dominates. Natural open space makes up only $11 \%$ of the landscape, while agriculture and urbanization dominate the rest (Table 3). Figure 5 depicts development closer to the city of Chicago, whereas agriculture is more common farther away.

\section{Drainages of Will County}

Will County is part of two continental basins: the Great Lakes and the Mississippi. These were historically separate except for a small seasonal connection between two natural depressions in Cook County: the Saganashkee Slough to the south and Mud Lake to the north. It has been hypothesized that other connections existed between creeks in Will and Cook counties during spring floods, but this has not been verified. There is now a permanent connection between the Great Lakes and Mississippi via the Chicago Sanitary and Ship Canal, although the U.S. Army Corps of Engineers has placed electric cables across the canal near Romeoville in an effort to stop the movement of fishes.

The surface hydrology of Will County is divided into three primary drainages. Creeks in the northern-northwestern part of Will County are part of the Des Plaines Drainage (Mississippi). Creeks in the southern-southeastern part of Will County are part of the Kankakee Drainage (Mississippi), although some creeks flow into Kankakee County before entering the Kankakee River. Creeks in the extreme northeastern part of Will County are part of the Lake Michigan drainage (Great Lakes). About 709 kilometers (443 miles) of river and creek have their borders within Will County (Fig. 2). The following section identifies individual creek systems, river kilometers and miles within the boundary of Will County, and a small account of characterization.

Great Lakes Drainage-Deer Creek (11.8 river kilometers/ 7.4 river miles) - A small creek that starts west of University Park and then flows northeast into Cook County, where it enters Thorn Creek.

Plum Creek (18.2 river kilometers/11.4 river miles)-A medium creek that starts north of Beecher and then flows northeast through the southeast corner of Cook County, then into Lake County, Indiana, where it is channelized and called Hart Ditch before entering the Little Calumet River.

Thorn Creek (4.3 river kilometers/2.7 river miles) - A small creek that starts northwest of University Park and then flows northeast into Cook County, where it enters the Little Calumet River.

Des Plaines River Drainage-Cedar Creek (13.3 river kilometers/8.3 river miles) - A medium creek that starts south of Preston Heights and flows west into the Des Plaines River. Sections of the creek have an exposed bedrock and rubble bottom. 


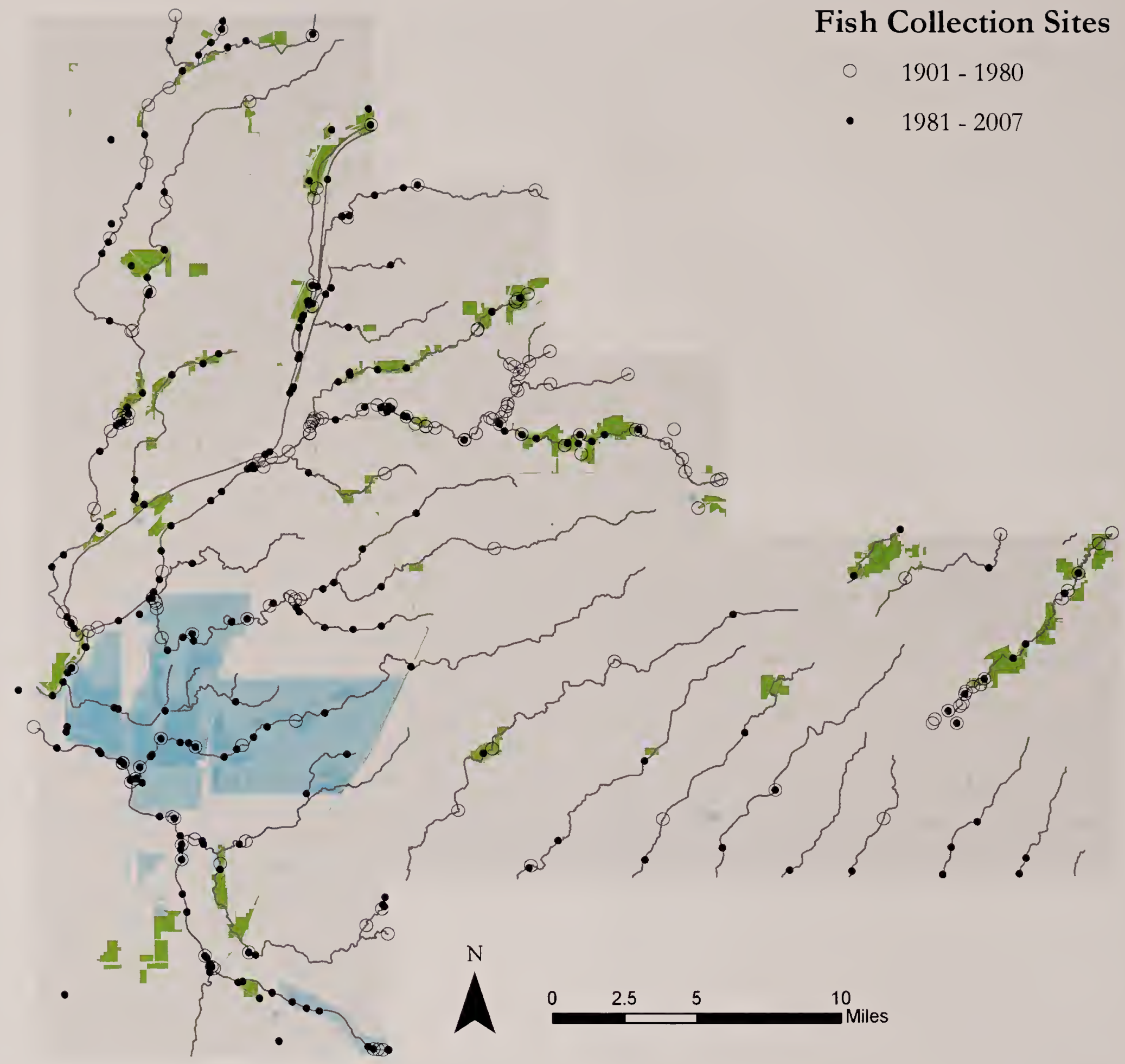

FIG. 3. Fish collection localities in Will County, Illinois. Open dots $(\mathrm{O})$ represent fish collections made 1980 and earlier $(\mathrm{n}=214)$. Solid dots $(\bullet)$ represent fish collections made 1981 and later $(\mathrm{n}=414)$. The 1980 cutoff date was chosen because the major implementations of the Clean Water Act were in 1972 and 1977, and it took a couple years for the first effects to be manifested. Furthermore, the cutoff date conveys the historic and current distribution of fishes. Green-shaded areas are overseen by the Forest Preserve District of Will County. Blue-shaded areas are overseen by Illinois Department of Natural Resources, United States Department of Agriculture / Forest Service, Department of Veteran's Affairs, or the United States Army (National Guard).

Des Plaines River (41.6 river kilometers/26 river miles) - A large river that starts near Union Grove, Racine County, Wisconsin. It then flows south through the center of Kenosha County, Wisconsin; eastern Lake County; the center of Cook County west of Chicago; the very southeast corner of DuPage County; and then south-southwest through western Will County before merging with the Kankakee River to form the Illinois River in Grundy County. Habitats in the Will County stretch of the Des Plaines River are varied. Some reaches are lower gradient and exhibit abundant backwater and side-creek wetland habitats (near Channahon). Some reaches are higher gradient where the channel braids and exhibits swift currents over bedrock, thus forming many riffles (near Romeoville Prairie). The creek channel at Lockport Prairie is artificial because of being moved during canal construction. The Des Plaines River below Lockport is deeper and wider, a result of modification for commercial navigation.
DuPage River (58.4 river kilometers/36.5 river miles)-A medium river. The West Branch starts near Schaumburg, Cook County, and the East Branch starts near Bloomingdale, DuPage County. These two branches meet in northern Will County to form the DuPage River proper, which flows south

TABLE 3. Will County land use in hectares, acres, square miles, and percent of aerial coverage. Based on 2004 United States Army Corps of Engineers aerial photography.

\begin{tabular}{lrrcc}
\hline Land use type & Hectares & \multicolumn{1}{c}{ Acres } & Square miles & \multicolumn{1}{c}{$\%$} \\
\hline Agriculture & $123,957.6$ & $306,302.7$ & 478.6 & 56.6 \\
Urban & $70,593.6$ & $174,438.6$ & 272.6 & 32.2 \\
Open space & $24,104.8$ & $59,563.7$ & 93.1 & 11.0 \\
Strip mine & 484.5 & $1,197.2$ & 1.9 & 0.2 \\
Total & $219,140.5$ & $541,502.2$ & 846.1 & 100 \\
\hline
\end{tabular}




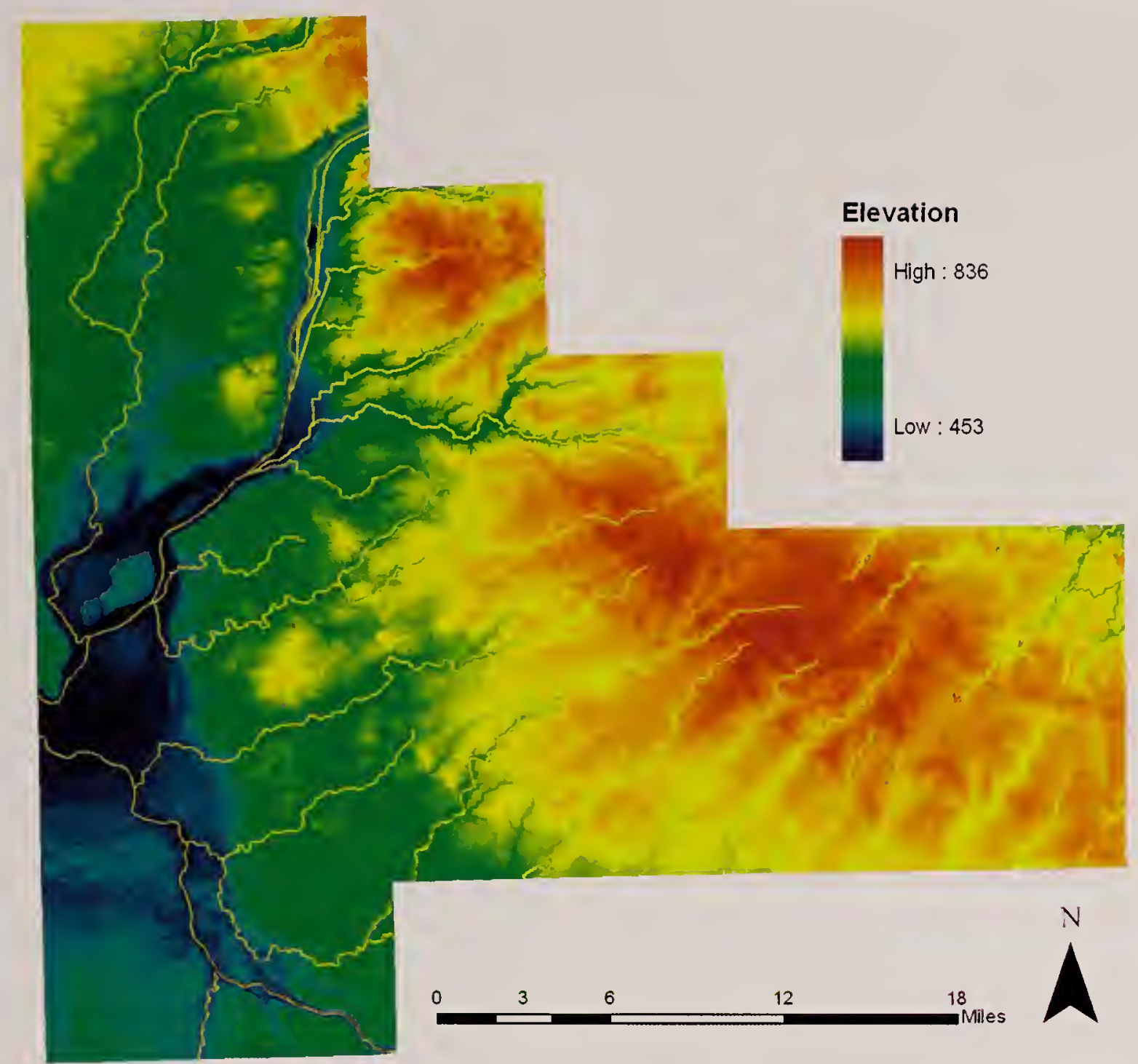

FIG. 4. Digital Elevation Model of Will County showing river and creek valley geomorphology.

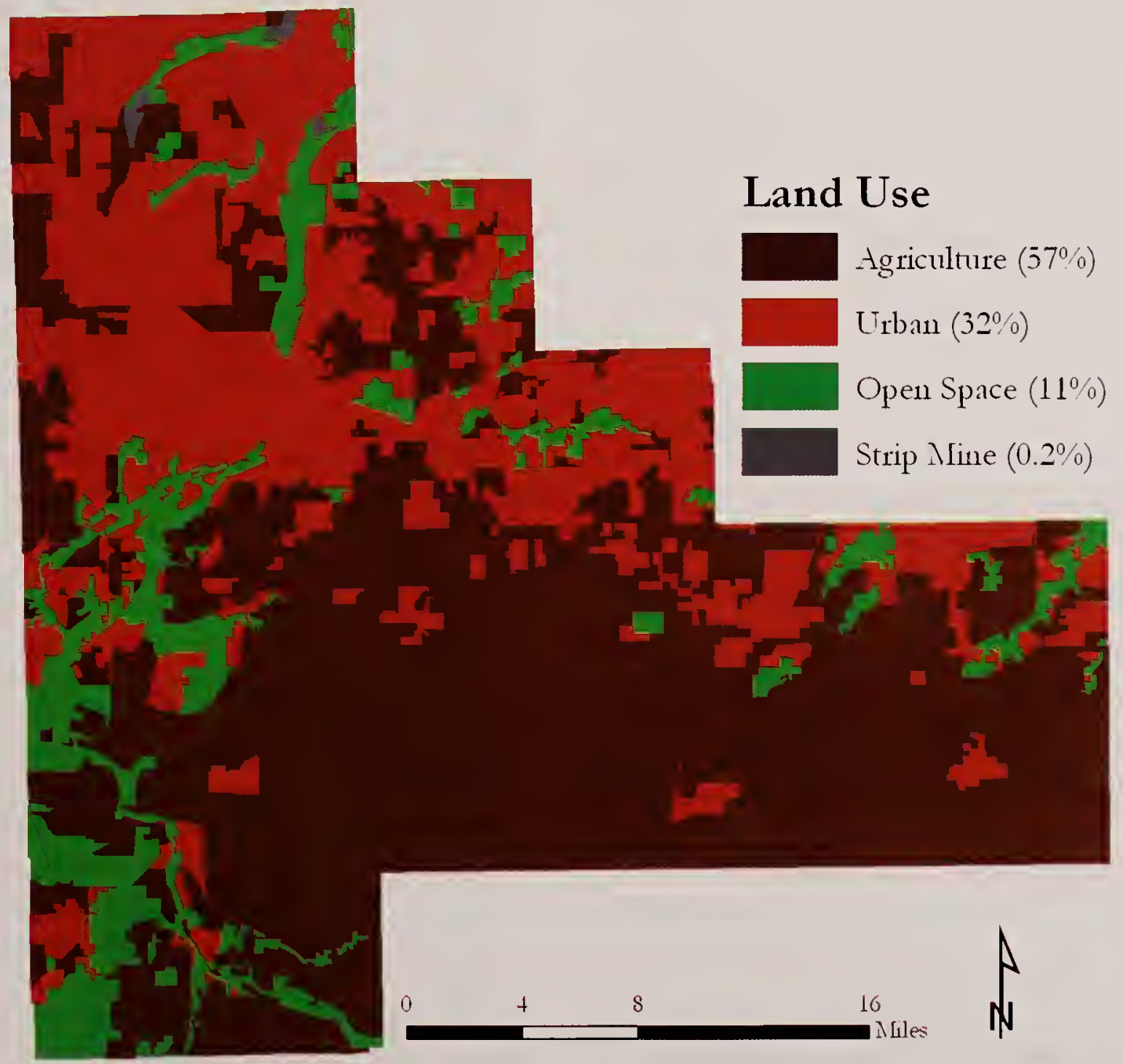

FIG. 5. Current Will County land use (based on 2004 United States Army Corps of Engineers aerial photography). 
into the Des Plaines River near Channahon. There is a dam near its confluence with the Des Plaines River.

Fiddeyment Creek (5.3 river kilometers/3.3 river miles) - A small bedrock and cobble-strewn creek that starts near Homer Glen and flows west through Lockport, where it descends the Des Plaines River valley bluff before joining with the Illinois and Michigan Canal. It shares many characteristics of headwater creeks and dries out to form isolated pools for portions of most years.

Fraction Run (11 river kilometers/6.9 river miles)-A medium creek that starts near Homer Glen and flows west through South Lockport, where it descends the Des Plaines River valley bluff before joining the Illinois and Michigan Canal. It shares many characteristics of headwater creeks and dries out, forming isolated pools for portions of most years.

Grant Creek (25 river kilometers/15.6 river miles)-A small creek that starts southeast of Elwood and flows west into the Grant Creek Cutoff, which is a backwater of the Des Plaines River.

Hickory Creek (34.9 river kilometers/21.8 river miles)-A large creek that starts near Park Forest, Cook County, and flows west into the Des Plaines River. The downstream section flows through Joliet and is highly modified. Spring Creek (17 river kilometers/10.6 river miles) and Marley Creek (18.7 kilometers $/ 11.7$ river miles) are major tributaries that join Hickory Creek from the north. The dam in Pilcher Park (Joliet Park District) is more than 3 meters tall.

Jackson Creek (56.8 river kilometers/35.5 river miles)—A large creek that starts south of Frankfort and flows southwest into the Des Plaines River. Manhattan Creek is a significant tributary of Jackson Creek. Habitat is very diverse; the lower reaches possess many riffles and exposed bedrock, whereas sections of the upper reaches are well vegetated with aquatic plants and slow flowing.

Keepataw Creek (0.8 river kilometers/0.5 river miles)-A headwater creek south of Bolingbrook that flows off the Des Plaines River valley bluff into the wetlands along the Des Plaines River. Essentially, the entire creek dries out when rainfall amounts are low. Not shown in Figure 2.

Lily Cache Creek (25.9 river kilometers/16.2 river miles) - $\mathrm{A}$ medium creek that starts near Bolingbrook and flows southwest and then south into the DuPage River. It is a low-gradient creek with sand and silt substrate.

Long Run (22.9 river kilometers/14.3 river miles)-A medium creek that starts near Orland Park, Cook County and flows west before descending into the Des Plaines River valley and joining the Illinois and Michigan Canal. This creek possesses a low gradient and a vegetated habitat in the upper reaches and bedrock and cobble habitats in the lower reaches.

Rock Run (13.9 river kilometers/8.7 river miles) - A small creek that starts north of Joliet and flows southwest and then south over the bluff into the Des Plaines River valley, where it joins the Illinois and Michigan Canal. Upstream sections are mud, silt, and some sand, but after the creek descends over the bluff and increases in gradient, the substrate converts to sand, gravel, and cobble.

Sugar Run (12.3 river kilometers/7.7 river miles) - A medium creek that starts south of New Lenox and flows west into the Des Plaines River. Also known as Sugar Creek. Substrate is predominantly mud and sand, with some cobble.

Kankakee River Drainage-Black Walnut Creek (19.5 river kilometers/12.2 river miles) - $\mathrm{A}$ medium creek that starts south of University Park and then flows southwest into
Kankakee County, where it enters South Branch Rock Creek. Substrate is usually sand covered by silt, as is common in agricultural areas.

Exline Slough (8.3 river kilometers/5.2 river miles) - A small creek that starts west of Beecher and then flows southwest into Kankakee County, where it transforms into Baker Creek. Exline Slough is quite different from the other creeks in eastern Will County in that it possesses a very soft mud bottom with abundant native vegetation.

Forked Creek (81.8 river kilometers/51.1 river miles)-A large creek that starts northwest of Monee and then flows southwest into the Kankakee River near Wilmington. A small stretch crosses northwest Kankakee County. A major tributary is South Branch Forked Creek, which starts west of Monee and then flows southwest into Forked Creek. A small stretch crosses northwestern Kankakee County. Jordan Creek (20.6 river kilometers/12.9 river miles) is a small tributary creek of Forked Creek that starts south of Manhattan and flows southwest into Forked Creek near Wilmington. Substrate is typically sand mixed with mud in low-gradient stretches and sand mixed with gravel in highgradient stretches.

Horse Creek (5.9 river kilometers/3.7 river miles) - A large creek that starts southeast of Cabery, Ford County, and then flows north through western Kankakee County and southwestern Will County before entering the Kankakee River near Custer Park. Habitat is extremely diverse in this creek with bedrock, cobble, and gravel being the dominant substrate types.

Kankakee River (31.8 river kilometers/19.9 river miles) - A large river that starts near South Bend, Indiana, and then flows west through northwestern Indiana, the center of Kankakee County, and finally through the southwestern corner of Will County before merging with the Des Plaines River in Grundy County to form the Illinois River. The Iroquois River is a major tributary from the south. The habitat in the Will County portion of the river is predominantly clean rubble and gravel bottom with a moderate to swift current.

North Branch Rock Creek (18.1 river kilometers/11.3 river miles)-A medium creek that starts south of Monee and then flows southwest into Kankakee County, where it joins with South Branch Rock Creek to form Rock Creek proper.

Pike Creek (7.4 river kilometers/4.6 river miles) - A small creek that starts east of Beecher and then flows south into Kankakee County, where it enters Trim Creek. This creek has been straightened and dredged for most of its length. Substrate is sand and gravel. Flow is slow, except after significant rain events.

Prairie Creek (40 river kilometers/25 river miles)-A medium creek that starts south of Frankfort and then flows southwest into the Kankakee River. The dam at Kemery Lake splits the creek into upstream and downstream sections.

South Branch Rock Creek (10.2 river kilometers/6.4 river miles)-A small creek that starts northeast of Peotone and then flows southwest into Kankakee County, where it joins with North Branch Rock Creek to form Rock Creek proper.

Terry Creek (3.4 river kilometers/2.1 river miles) - A small, high-gradient tributary of the Kankakee River. Habitat is extremely diverse in this creek with bedrock, cobble, and 
gravel being the dominant substrate types. Not shown on Figure 2.

Trim Creek (9.9 river kilometers/6.2 river miles) - A small creek that starts east of Beecher and then flows northwest and then south to form a fishhook before entering the Kankakee River in Kankakee County. This creek has been straightened and dredged for most of its length.

Unnatural Waterways - Chicago Sanitary and Ship Canal (14.4 river kilometers/9 river miles) - This canal was constructed between 1892 and 1900, with additional work on the Des Plaines River until 1907 (Hill, 2000). The canal flows from Chicago, Cook County, to Lockport, where it merges with the Des Plaines River.

Illinois and Michigan Canal (29.9 river kilometers/18.7 river miles) - This canal was constructed between 1836 and 1848. It begins in Chicago, Cook County, and then largely follows along the southern edge of the Des Plaines River until it reaches Joliet, where it crosses to the northern edge of the Des Plaines River, merging for a time with the DuPage and Des Plaines rivers near Channahon. From there, it used to flow into the Illinois River at La Salle, La Salle County. The Illinois and Michigan Canal was closed to navigation in 1933 and replaced by the Chicago Sanitary and Ship Canal (Hill, 2000). The canal is a highly artificial habitat. The upstream portion (south and east of the Des Plaines River) receives a lot of urban runoff. Significant stretches of the downstream portion (north and west of the Des Plaines River) are stagnant.

\section{Aquatic Habitats of Will County}

Headwater CReeks-These are a particularly harsh environment for fishes because they frequently dry out during summer (Fig. 6A) and are dry or completely frozen during winter. Isolated pools may remain during the summer (Fig. 6B), but oxygen and food quickly become limited. Water fills the creeks in the spring; however, heavy rains cause large pulses of water to scour the streambed and change creek habitat configuration. Only hardy fishes that are superior recolonizers are found consistently in headwater creeks.

The headwaters of all creeks in Will County fit this description, dependent on weather and the surrounding upland hydrology. For example, large portions of some creeks will dry out during drought years, such as during the summer and fall of 2005.

CreEks-These are the most common aquatic habitat in Will County. Water levels may rise and fall seasonally, but there is always some water present (Fig. 6C). Habitats include riffles, pools, runs, vegetation, woody debris, and undercut banks. Current may be fast or slow. Substrates include clay hardpan, detritus, mud, sand, gravel, rubble, or bedrock. In other words, there is a lot of variability both within a single creek and among different creeks.

There is usually riparian vegetation in the form of shrubs and trees along the banks (Fig. 6D). This vegetation shelters the creeks from excessive sunlight. The vegetation also provides allochthonous input of nutrients in the form of falling leaves and insects (i.e., food for fishes). Fallen branches and tree trunks provide habitat, breaks in current, and refuge from predators.

Natural creeks meander, twisting and turning through the landscape. Some creeks have been channelized to form straight ditches. Ditches are most common in agricultural settings and are usually made to facilitate drainage. Riparian vegetation is often minimal under these circumstances. Diversity of fishes is typically lower in channelized creeks because the environment is harsher and habitat heterogeneity lower than in natural creeks.

Rivers-Two large rivers, the Kankakee and the Des Plaines (Fig. 6E, D), cut through western Will County. Habitats are similar to that found in creeks but on a larger scale. Many fish species live in rivers because they hold a lot of water and have a high diversity of habitats. Because fishes can move long distances through rivers, they often act as refuges for their own tributaries when these tributaries dry up or freeze, which is important for colonization and recolonization events.

Like creeks, natural rivers meander but may be channelized, dredged, and dammed to facilitate shipping. Channelized and dammed rivers typically have fewer species of fishes than unmodified rivers because of their lower habitat heterogeneity and fragmentation. Portions of the Des Plaines River fit this description.

Artificial rivers, notably the Illinois and Michigan Canal and the Chicago Sanitary and Ship Canal, are also present in Will County. They usually have fewer species of fishes than natural rivers because of their lower habitat heterogeneity. Pollution also severely limits what fishes can live in these particular canals.

Ponds/LAKEs/REservolRs - Natural standing bodies of water are uncommon in Will County and are manifested mostly as open-water wetlands. Human-constructed reservoirs or flooded mine pits, such as the Dresden Cooling Lake and mine pits in the Braidwood area, are also present. Wetlands are usually associated with the edges of ponds and lakes or the backwaters of large rivers.

Many ponds and lakes are stocked with game fishes for the enjoyment of anglers. Development around ponds usually leads to the removal of riparian vegetation, increased erosion, increased nutrient input from lawns, and so on, resulting in eutrophication. Sensitive species are eliminated by this process. Some ponds dry up during the summer or freeze completely during the winter. If these ponds are not connected to a nearby creek or river, very few fish will be present because there is no opportunity for recolonization when water returns. However, these fishless ponds can become prime habitat for amphibians (i.e., some amphibians avoid spawning in ponds with fishes).

MARSHES AND BACKWATERs-Marshes and backwaters along rivers serve as critical nursery areas during spring high waters. Juvenile fishes have access to an abundance of food and plenty of cover to hide from predators. They are also sheltered from the strong currents in the river proper and hence are not washed into unfavorable habitats or the jaws of a hungry predator. The north end of Romeoville Prairie is a particularly large example of a backwater in Will County. Smaller examples can be found along the edges of every creek, river, pond, and lake. A small patch of flooded vegetation can act as a marsh/backwater.

\section{Annotated Checklist of Fishes}

There are 112 species in 23 families recorded from within the boundaries of Will County. (See Appendix for summary 
A)

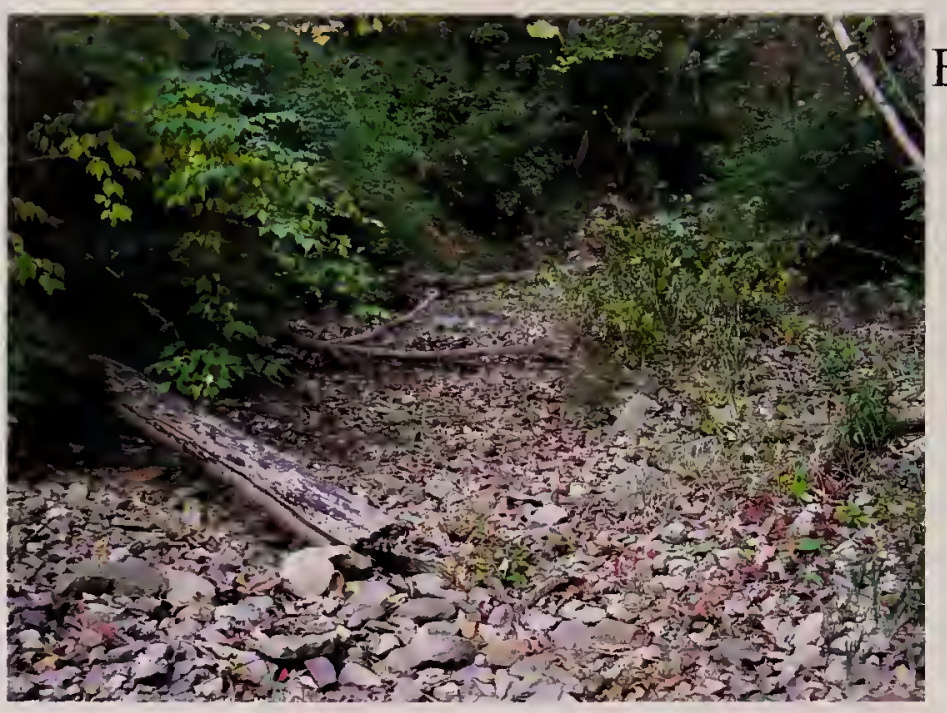

C)

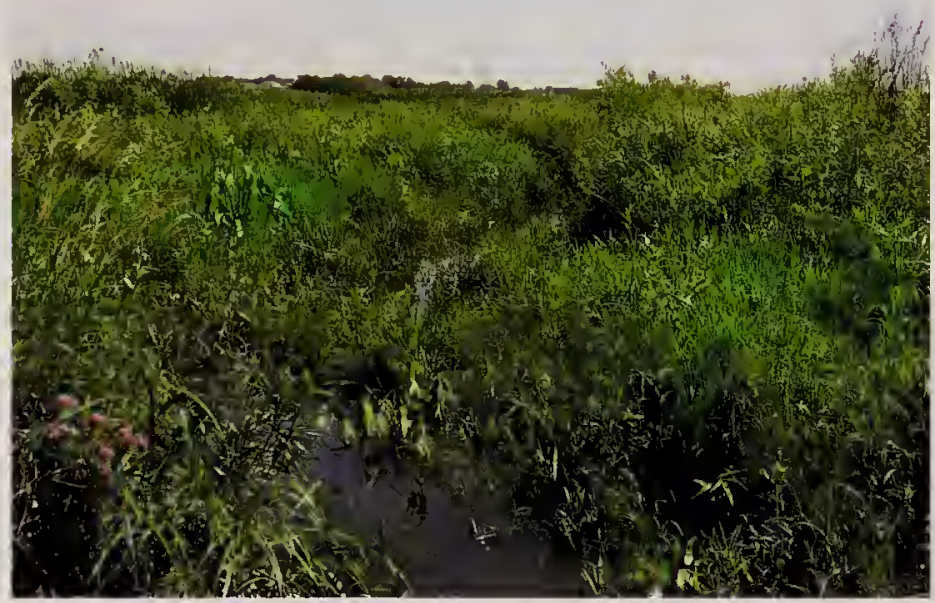

B)

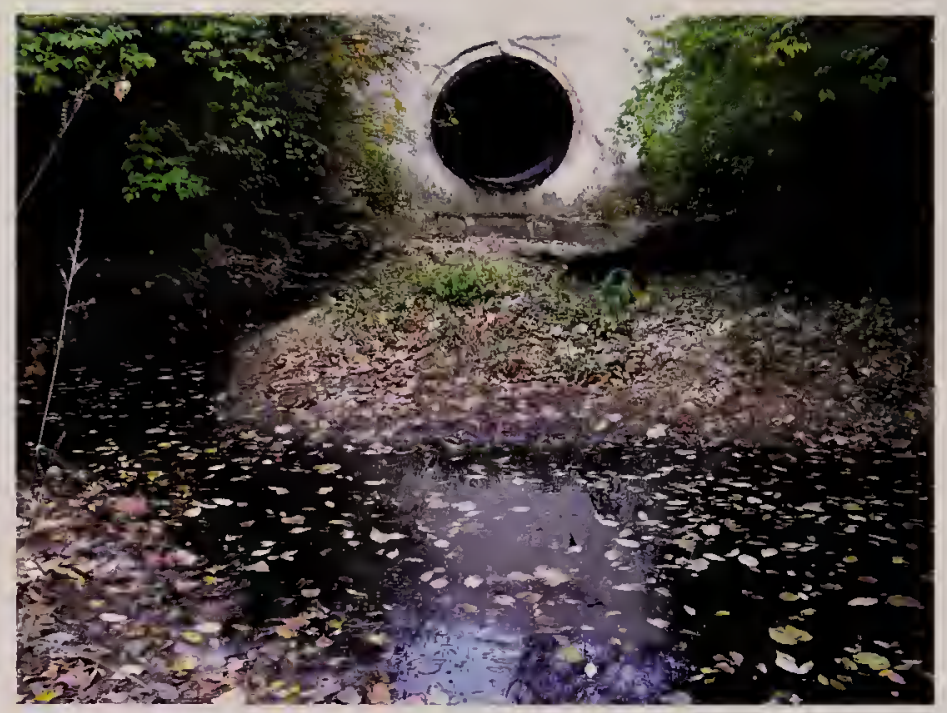

D)

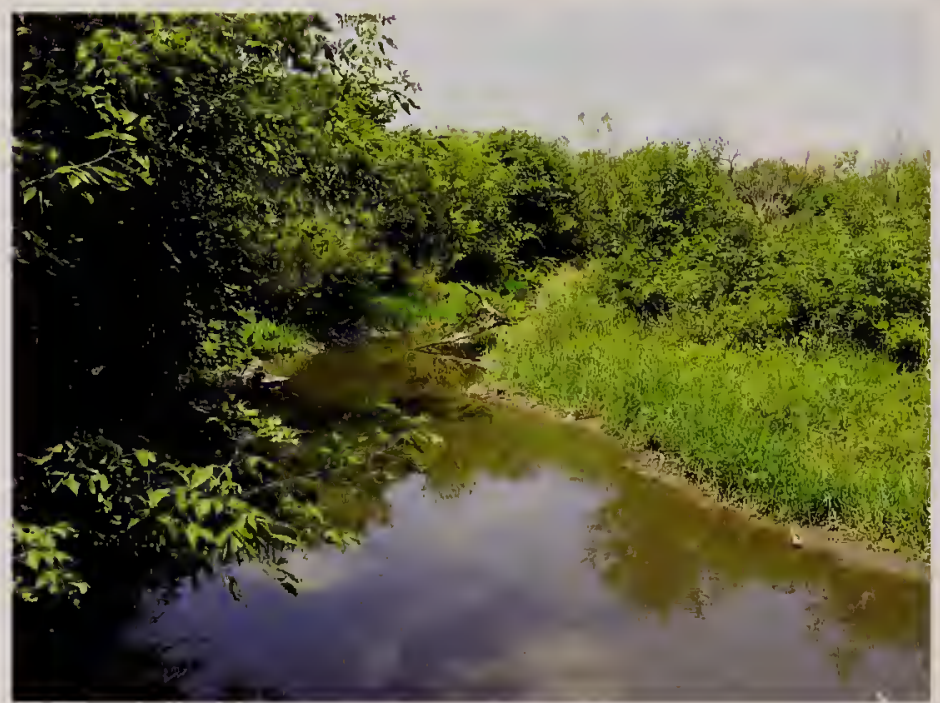

E)
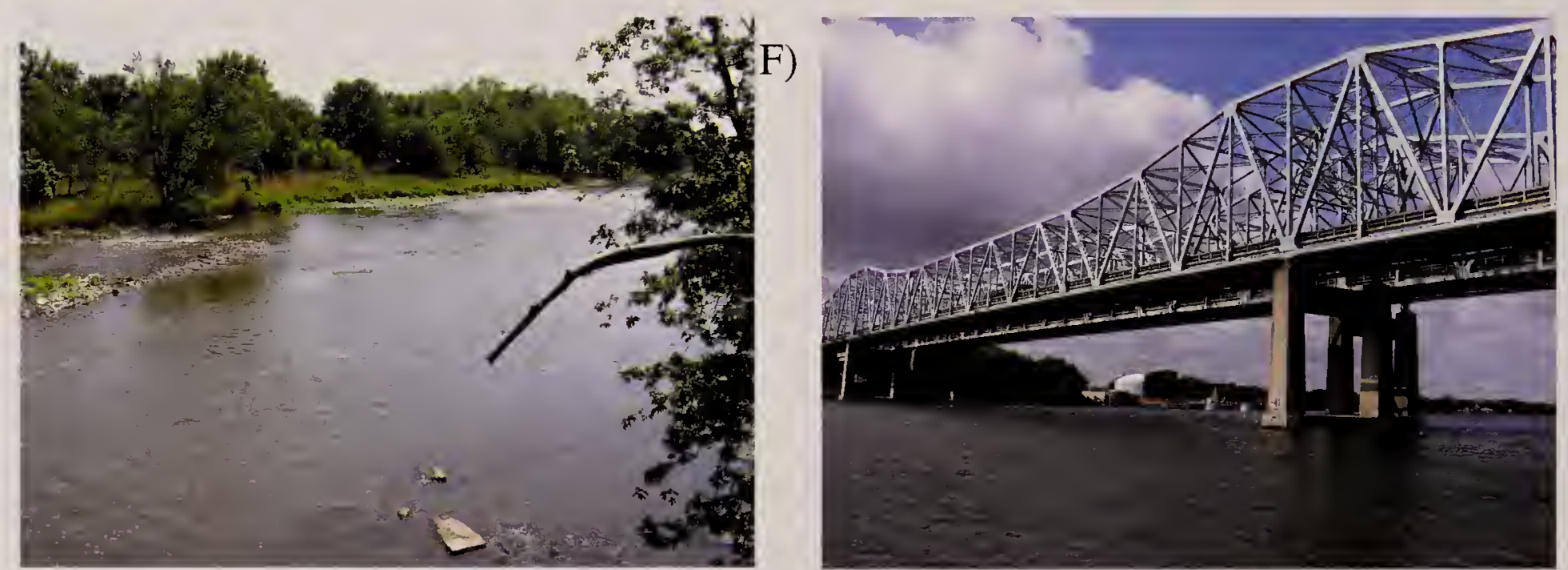

Fig. 6. Common aquatic habitats in Will County, Illinois, 2005. A) Headwater creek - Seasonally dry section of Keepataw Creek, north of Bluff Road; B) Headwater creek - Isolated pool of water in Keepataw Creek, south of Bluff Road; C) Creek - Upper portion of Rock Run flowing through a prairie near Gaylord Road; D) Creek - Rock Run at Mound Road; E) River - Des Plaines River at Lockport Prairie; F) River - Des Plaines River at Interstate 55 crossing.

checklist, Figs. 7-21 for images, and Figs. 22-91 for distribution maps.) Eleven species are introduced or nonnative. Other species not in the annotated checklist are known from adjacent counties and may eventually be found in Will County. These species of hypothetical occurrence include Anguilla rostrata (Lesueur) American Eel, Ctenopharyngodon idella (Valenciennes) Grass Carp, Erimyzon sucetta (Lacépède) Lake Chubsucker, and Morone saxatilis (Walbaum) Striped Bass.

Comments on distribution, habitat preferences, abundance, and so on are based on personal observations and historical records (see Figs. 22-91) within Will County unless otherwise noted. Ecological characteristics may not be true for a given species elsewhere within its range. Threatened and endangered designations are according to 2004 State of Illinois listings.

\section{Lepisosteidae (Gars)}

LEPISOSTEUS OSSEUS (LinNAEUs)-Figure 22-The Longnose Gar is found throughout the Kankakee and lower Des Plaines rivers. It prefers backwaters, sluggish pools, and margins of large rivers and seems to prefer open water.

LePisosteus Platostomus RAFINESQUe-Figure 22-The Shortnose Gar is found in the lower Kankakee River. It prefers backwaters, sluggish pools, and margins of large rivers. 
It is quite rare in Will County and the extreme upper Illinois River.

\section{Amiidae (Bowfin)}

AMIA CALVA Linnaeus-Figure 23-The Bowfin has been collected only from the Kankakee River. It prefers wellvegetated backwaters and side-stream wetlands. It is common upstream in the Kankakee River in Kankakee County and is likely in the Des Plaines River in Will County.

\section{Hiodontidae (Mooneyes)}

Hiodon alosoides (RAFINEsque)-Figure 23-The Goldeye is sporadic in the Kankakee River. It is a big-river species, and Will County is on the northeastern edge of its range (Page \& Burr, 1991).

Hiodon tergisus Lesueur-Figure 23-The Mooneye is sporadic in the Kankakee River. It is a big-river species.

\section{Clupeidae (Herrings and Shads)}

ALOSA CHRYSOCHLORIS (RAFINESQUE) -Figure 24-The Skipjack Herring is in the lower portions of the Des Plaines and Kankakee rivers. It prefers large rivers with sand and gravel beds (Smith, 1979). Smith (1979) notes that this is a schooling fish; however, collections made by the authors included only one individual at three separate sites in the lower Des Plaines River. This is the northern extent of its range (Page \& Burr, 1991). It was quite rare in the past but with water quality improvements and the warming of local waters the number of occurrences has increased.

DOROSOMA CEPEDIANUM (LESUEUR)-Figures 7, 25-The Gizzard Shad is a common species. Larger individuals are in rivers and lakes, but juveniles can be found in creeks. It can be extremely abundant in the Kankakee and Des Plaines rivers.

DOROSOMA PETENENSE (GÜNTHER)-Figure 24-The Threadfin Shad was introduced in the southeastern United States in the 1940s and has been spreading northward (Laird \& Page, 1996). It is from Central America and the southern United States and is often thought to not be cold tolerant; however, it appears to be able to survive local winters.

\section{Cyprinidae (Carps and Minnows)}

CAMPOSTOMA ANOMALUM (RAFINESQUE)-Figure 26-The Central Stoneroller is one of the most common species. It is found in creeks and occasionally rivers, with exposed bedrock or rubble. It uses the cartilaginous ridge on its lower jaw to scrape algae and diatoms off of rocks.

CAMPostoma OLIGOLEPIS HubBs \& Greene-Figure 26-The Largescale Stoneroller has several scattered locality records in Will County, which is along the southeastern edge of its range (Page \& Burr, 1991). It is ecologically similar to C. anomalum.

Carassius aURatus (LinnaEus) - Figure 27-The Goldfish was established in Illinois by 1876 (Nelson, 1876). There are records of it being introduced into Chicago lagoons during the 1893 World's Fair (Woods, 1960). Discarded pets have resulted in countless reintroductions since then. Descendants rapidly lose bright colors in the wild. It is not a good competitor and does not have any apparent impacts on native fishes or habitats. It prefers highly disturbed habitats where competition is limited. It is common in the Chicago Canal
System and lower Des Plaines River, where it can reach up to 30 centimeters in length. Often hybridizes with Cyprinus carpio.

CyPRINELLA LUTRENSIS (BAIRD \& GiRARD)-Figure 28-The Red Shiner is found in the southwestern corner of Will County. This is the eastern edge of its range (Page \& Burr, 1991). It is predominantly a creek species that sometimes lives in smaller rivers.

CYPRINELLA SPILOPTERA (COPE)-Figure 28-The Spotfin Shiner is one of the more common and abundant fishes. It prefers larger creeks and rivers but can be found in other habitats.

Cyprinella whipplei has sporadically been reported throughout the Chicago region. Every specimen that we and others have examined turned out to be misidentified $C$. spiloptera. Cyprinella whipplei should not be considered part of Will County's fauna until there is a professionally identified voucher specimen.

CYPRINUS CARPIO LinNaEUS-Figure 29-The Common Carp was first introduced into Illinois in 1879 (Cole, 1905). It has since spread throughout the region. Larger individuals are in rivers and lakes, but juveniles are found in smaller bodies of water.

Hybopsis amnis (HubBs \& GreENE)—Figure 30-The Pallid Shiner is endangered. One of the largest populations in Illinois is in the lower Kankakee River. It prefers larger rivers with sand or silt bottoms. Its population is currently stable in Will County but is of concern and should be monitored closely.

HYPOPHTHALMICHTHYS MOLITRIX (VALENCIENNES)-No map-The Silver Carp was originally brought into the United States for aquaculture in the 1970s but subsequently escaped into the Mississippi River. It has been moving up the Illinois River and dramatically increasing in numbers (Kolar et al., 2007). There are no vouchered museum specimens at this time, but in 2004 one was found in the Chicago Sanitary and Ship Canal 3 kilometers downstream of Romeoville. It is expected to become more common in Will County in the future. The U.S. Army Corps of Engineers has constructed two electric barriers in the Chicago Sanitary and Ship Canal near Romeoville to prevent the spread of this species and $H$. nobilis into the Great Lakes.

HYPOPHTHALMICHTHYS NOBILIS (RICHARDSON)-No mapThe Bighead Carp was originally brought into the United States for aquaculture in the 1970 s but subsequently escaped into the Mississippi River. It has been moving up the Illinois River and dramatically increasing in numbers (Kolar et al., 2007). There are no vouchered museum specimens at this time, but in 2007 two individuals were caught by fishermen in the Des Plaines River at Channahon. It is expected to become more common in Will County in the future. The U.S. Army Corps of Engineers has constructed two electric barriers in the Chicago Sanitary and Ship Canal near Romeoville to prevent the spread of this species and $H$. molitrix into the Great Lakes.

LUXILUS CHRYSOCEPHALUS RAFINESQUE-Figure 31-The Striped Shiner is in almost every creek and river. It often hybridizes with the common shiner (see Luxilus cornutus for more details). It is likely that the Plum Creek striped shiner record is actually a hybrid.

LuXilus CoRnutus (Mitchill)-Figure 32-The Common Shiner is not as abundant as its congener, the striped shiner $L$. chrysocephalus. There are several populations in Will County, most notably the upper DuPage River, Jackson Creek, and Plum Creek. This is the southern edge of its range (Page \& 
Burr, 1991) as well as the part of its range that overlaps with the distribution of the striped shiner. These two species hybridize (Dowling \& Hoeh, 1991). All individuals from Plum Creek that we examined showed signs of introgression. It is possible that every common shiner in Will County has some degree of genetic exchange with striped shiners.

LythruRUS UMBRATILIS (GIRARD) -Figure 33-The Redfin Shiner is found throughout Will County. It is not usually collected in large numbers but is often present. The Hickory Creek population has apparently been extirpated. It prefers still to slow-moving waters in creeks but can be found elsewhere.

Nocomis bigutTatus (KiRTLAND)-Figure 34 The Hornyhead Chub is found in almost every watershed. It is predominantly a creek fish but also lives in rivers. It is most abundant over rubble or gravel bottoms.

NoteMigonus CRYSOLEUCAS (MitchiLl) - Figure 35-The Golden Shiner is found throughout Will County but not usually in large numbers. It is tolerant of pollution, so it is often collected in degraded habitats as well as relatively unmodified habitats of quiet vegetation.

NOTROPIS ATHERINOIDES RAFINESQUE-Figure 36-The Emerald Shiner is found in the western half of Will County. It is fairly common in lakes, rivers, and larger creeks, usually with clear water.

NotRopIS BLENNIUS (GIRARD) -Figure 37-The River Shiner may be found in Will County, but we are unsure of its exact distribution. There are scores of literature records from $100+$ years ago, but at that time $N$. blennius was a species complex. Subsequent taxonomic revisions split it into several species. Every putative River Shiner examined was reidentified as Notropis stramineus, Notropis dorsalis, or Notropis volucellus; however, there are River Shiners in the Illinois River, so stray individuals may enter Will County. The status of the River Shiner in Will County is uncertain.

NotRoPIS BOOPS GILBERT-Figure 37-The Bigeye Shiner is endangered. There is only one record in Will County, in the Kankakee River. It prefers high-gradient creeks with clear water, clean substrate, and nearby vegetation and hence is sensitive to sedimentation (Smith, 1979). It is highly unlikely that there is currently a viable population.

NotROPIS BUCCATUS (COPE) - Figure 37-The Silverjaw Minnow is found in the southern half of Will County. It prefers creeks with sand bottom and moderate current and is tolerant of slight sedimentation, but excessive sedimentation will cover its habitat. Not usually collected in large numbers.

Notropis bUCHANanI Meek-Figure 38 - The Ghost Shiner is found in the Kankakee River. It is a river species that prefers quieter sections with a sand bottom.

NOTROPIS CHALYBAEUS (COPE) - Figure 38-The Ironcolor Shiner is threatened. There is only one record in Will County, in the Kankakee River. This species prefers creeks to small rivers with a slow to moderate current, clear water, sand bottom, and abundant vegetation. A population resides in the tributaries of the Kankakee River in Kankakee County, and the Will County record is probably an individual that dispersed from there.

Notropis DORSALIS (Agassiz) -Figure 38-The Bigmouth Shiner is found in the western half of Will County, where it is relatively abundant in creeks and small rivers with sand and slightly silty bottoms. It is common to the west of Will County, but populations are rare and decreasing to the east (Page \& Burr, 1991).
Notropis heterolepis EigenMann \& EIgenManN-Figure 39-The Blacknose Shiner is endangered. It prefers ponds and lakes with clear water and abundant native vegetation but can be found in slow-moving creeks with similar conditions. The species has two records in the Hickory Creek watershed, but it has not been seen in years and is believed to have been extirpated (Burr et al., 2005).

Notropis hudsonius (Clinton) - Figure 39-The Spottail Shiner is occasionally in the Des Plaines and Kankakee rivers. It prefers larger rivers and lakes. There are significant populations in Lake Michigan and the Illinois River. Individuals collected in Will County probably dispersed from these larger populations.

NotRopIS RUBELLUS (AgAssiz)-Figure 39-The Rosyface Shiner is found in Hickory Creek, Jackson Creek, Prairie Creek, and the Kankakee River. It prefers flowing water ranging from large creeks to medium-sized rivers.

Notropis StRamineus (COPE) - Figure 40-The Sand Shiner is a common and abundant species, found in essentially every watershed, often in large numbers. It prefers creeks with sand or gravel bottoms and clear water but is tolerant of other conditions.

NotRopIS TEXANUS (GIRARD) - Figure 41-The Weed Shiner is endangered. There are a couple of historical records in the Kankakee River but no recent collections. It prefers creeks to small rivers with a slow to moderate current, clear water, sand bottom, and abundant vegetation. There is a population in the tributaries of the Kankakee River in Kankakee County, and the Will County specimens are probably individuals that dispersed from there.

NotRoPIS VOLUCELLUS (COPE) -Figure 41-The Mimic Shiner is found in the DuPage River, Kankakee River, and some of their larger tributaries. In this part of its range, it prefers larger rivers with clean bottoms and can be very abundant.

Opsopoeodus EmILIAE HaY - Figure 42 - The Pugnose Minnow has been collected three times in the Kankakee River. It is usually found in lakes or backwaters with clear water and abundant vegetation but can also be found in still-water creeks with similar conditions. The Will County localities do not fit this description, so we suspect these individuals dispersed from Indiana or the Kankakee County sections of the Kankakee River.

PHENACOBIUS MIRABILIS (GIRARD)-Figure 42-The Suckermouth Minnow is found in the southwestern corner of Will County but not in large numbers. It appears to have been extirpated from Hickory Creek and other headwater creeks in southeastern Will County. There are no records in the Will County section of Plum Creek, but they are present downstream (J. Mendelson, pers. comm.).

PHOXINUS ERYTHROGASTER (RAFINESQUe)-Figure 42-The Southern Redbelly Dace is found in the headwater creeks of many drainages. It is most abundant over sand or gravel bottoms but can be found in other conditions.

PImephales notatus (RAFinesque)-Figure 43-The Bluntnose Minnow is a common and abundant species, found in every drainage, often in large numbers. It can survive harsh conditions and is one of the first species to recolonize temporarily dried-out creeks. It is also tolerant of pollution and degraded habitats.

PIMEPHALES PROMELAS RAFINESQUE-Figure 44 -The Fathead Minnow is found throughout Will County. It prefers the calmer sections of creeks, ponds, and wetlands. It is able to survive low oxygen levels and other harsh conditions. Tolerant of pollution, it can be found in degraded habitats. 
Pimephales VigilaX (BAIRd \& Girard)-Figure 44 The Bullhead Minnow is found in the Kankakee and Des Plaines rivers. It is a river species that prefers a slow to moderate current and relatively clean bottoms.

RHINICHTHYS ATRATULUS AgAssiz-Figure 45-The Blacknose Dace has been collected only in Pike Creek, Trim Creek, and Terry Creek. It prefers headwater creeks with cool, clear water. Most Will County creeks are too warm.

SCARDINIUS ERYTHROPHTHALMUS (LINNAEUS)-Figure 45The Rudd is an invasive species that has been reported, but whenever we look into these reports, the species in question turns out to be misidentified Golden Shiners $N$. crysoleucas. Some records in Will County probably are valid (Laird \& Page, 1996). If this species is established in Will County, its numbers are not high at this time.

SEMOTILUS ATROMACULATUS (Mitchill) -Figure 46-The Creek Chub is a common and abundant species in every watershed in Will County, often in large numbers. As its name implies, it is a creek species, sometimes collected in only a couple centimeters of water.

\section{Cobitidae (Loaches)}

Misgurnus anguilliCAUDATUS (CANTOR)-Figures 8, 46The Oriental Weatherfish was first recorded in Illinois in 1987 (Laird \& Page, 1996). We knew of its existence in the Chicago Canal System and lower Des Plaines River, usually in severely degraded habitats. We collected additional specimens in Lockport Prairie and Keepataw Creek during the summer of 2005. There are unverified reports of it even further upstream in the Des Plaines River, so it appears to be expanding its range. It is unclear what impact this invasive species will have on aquatic ecosystems. It can survive in low-oxygen environments, and its native habitat is ponds, swamps, and rice paddies (Okada, 1960). We suspect that it will preferentially colonize wetlands, backwaters, and other still-water habitats.

\section{Catostomidae (Suckers)}

CARPIODES CARPIO (RAFINESQUE) Figure 47-The River Carpsucker is found in the Des Plaines and Kankakee rivers. It is a river fish, although it can be found in creeks that are direct tributaries to larger rivers. Will County is the northeastern edge of its range (Page \& Burr, 1991).

CARPIODES CYPRINUS (Lesueur) - Figure 48-The Quillback is a fairly common species. It prefers rivers, lakes, and larger creeks.

CARPIODES VELIFER (RAFINESQUE)-Figure 48-The Highfin Carpsucker has been recorded a few times in the Kankakee River. It is a river species. Will County is the northeastern edge of its range (Page \& Burr, 1991).

Catostomus COMmersonil (LACÉPÈde)-Figure 49-The White Sucker is one of the most common species. It is predominantly a creek species but is also found in rivers, ponds, and lakes. It prefers mud and sand bottoms; however, it utilizes a variety of habitats.

ERIMYZON CLAVIFORMIS (GIRARD)-Figure 50-The Western Creek Chubsucker is uncommon. It prefers clear-water creeks with vegetation and a steady current but is sometimes found in ponds and lakes. There are historical records in Long Run and Marley Creek, but these populations are probably extinct. The only known surviving population is in Jackson Creek, but it is threatened if turbidity and sedimentation increase in the watershed.
HYPENTELIUM NIGRICANS (LESUEUR)-Figure 50-The Northern Hog Sucker can be found in the DuPage and Kankakee rivers. It generally prefers habitats with a significant water flow and clean bottoms. There were once populations in Hickory Creek and other drainages, but these have apparently been extirpated because of sedimentation. The DuPage and Kankakee populations appear to be stable.

ICTIOBUS BUBALUS (RAFINESQUE)-Figure 51-The Smallmouth Buffalo is in the Kankakee, Des Plaines, and DuPage rivers, although juveniles are sometimes found in nearby creeks. It prefers rivers, lakes, and impoundments.

ICTIOBUS CYPRINELLUS (VALENCIENNES)-Figure 52-The Bigmouth Buffalo is occasionally collected in the Kankakee and lower Des Plaines rivers. It is a river species.

ICTIOBUS NIGER (RAFINESQUE)-Figure 52-The Black Buffalo is occasionally collected in the Kankakee and lower Des Plaines rivers. It is a river species, although juveniles can be collected in creeks.

Minytrema MELANOPS (RAFINESQue) -Figure 53-The Spotted Sucker is sporadic in the Des Plaines and Kankakee rivers. It is a river species that prefers moderately clean substrates but can sometimes be found in nearby creeks. It is rarely collected in large numbers.

Moxostoma anisurum (RAFInesque)-Figure 54 -The Silver Redhorse is a large fish found in the DuPage and Kankakee rivers. It prefers rivers and impoundments but can also be collected in lakes that are attached to large rivers.

MoXostona CARINATUM (COPE)-Figures 9, 55-The River Redhorse is threatened. One of the largest populations in the state is in the lower Kankakee River. It is also occasionally collected in the DuPage River (Retzer \& Kowalik, 2002). The River Redhorse is a large fish that forages along the bottom for mussels and other invertebrates that it crushes with massive pharyngeal teeth (Willink, 2002). It lives in large rivers with swift current and clean rubble bottom and is sensitive to sedimentation. This population is currently stable but is of concern and should be monitored closely.

Moxostoma DUQUESNEI (LeSUEUR)_Figure 56-The Black Redhorse is in the Kankakee watershed and a couple other localities. It lives in rivers and larger creeks with swift current and clean rubble bottom. It is moderately sensitive to sedimentation.

MOXOSTOMA ERYTHRURUM (RAFINESQUE)-Figure 57-The Golden Redhorse is found throughout the western half of Will County, although the Hickory Creek population may have been extirpated. It lives in medium creeks to large rivers with flowing water. It is not as sensitive as other redhorses to sedimentation.

MOXOSTOMA MACROLEPIDOTUM (LESUEUR) - Figures 10, 58The Shorthead Redhorse is found in the DuPage, Des Plaines, and Kankakee rivers. It lives in large rivers, medium-sized creeks, impoundments, or lakes connected to large rivers. As with other redhorses, it forages for aquatic invertebrates along the bottom (Willink, 2002) and is moderately sensitive to sedimentation.

\section{Ictaluridae (Bullhead Catfishes)}

Ameiurus Melas (RAFinesque)-Figures 11, 59-The Black Bullhead is found in creeks and rivers. It prefers pools and undercut banks of creeks over mud where there is woody debris or root clumps to hide in. 
A MEIURUS NATALIS (Lesueur) - Figure 60-The Yellow Bullhead is found in large creeks and rivers. It prefers pools and undercut banks of creeks over mud where there is woody debris or root clumps to hide in.

Ameiurus nebulosus (Lesueur)-Figure 61-The Brown Bullhead prefers the well-vegetated backwater areas of large rivers. It is in the backwaters of the lower Des Plaines and Kankakee rivers but is rare.

ICTALURUS PUNCTATUS (RAFINESQÜE)-Figure 61-The Channel Catfish prefers large river channels; however, they frequently ascend smaller creeks and seek out the deeper pools. It is found throughout Will County, especially in the Des Plaines, DuPage, and Kankakee rivers, and is common.

Noturus EXILIS Nelson-Figure 62-The Slender Madtom prefers the fast-moving waters of cobble riffles in medium to large creeks. It is largely restricted to the prairie creeks of Midewin National Tallgrass Prairie and the Joliet Training Area. It formerly occurred in Hickory Creek but is most likely extirpated. Its status is stable, but its small range warrants watching to ensure survival.

Noturus flavUs RAFINESQUE-Figure 63-The Stonecat prefers the fast moving riffles of small creeks to large rivers. It may be found throughout Will County, especially in the DuPage and Kankakee river systems. It is possibly extirpated from Hickory Creek.

Noturus GYRINUS (Mitchill)-Figure 64-The Tadpole Madtom is the smallest catfish in Will County and prefers low-gradient creeks and the well-vegetated backwaters of rivers. It may be found throughout Will County, especially along the quiet margins and backwaters of the DuPage, Des Plaines, and Kankakee rivers.

Noturus nocturnus Jordan \& Gilbert-Figure 64 -A Freckled Madtom was collected in the Des Plaines River in 2005. This was the first time in over 100 years that this fish had been found this close to Chicago (Willink et al., 2006) and was even worthy of media attention (Bowman, 2005; Parker, 2006). It prefers the moving waters of riffles in large rivers. Its status is rare, but with improvements in water quality, its abundance may increase.

PYLODICTIS OLIVARIS (RAFINESQUE)-Figure 65-The Flathead Catfish is the largest catfish in Will County. It prefers undercut banks and deep pools of large rivers; the juveniles prefer cobble riffles that have an abundant supply of macroinvertebrates. It is found predominantly in the Kankakee River downstream of the Wilmington Dam.

\section{Esocidae (Pikes)}

ESOX A MERICANUS VERMICULATUS LESUEUR-Figures 12, 66The Grass Pickerel is a small relative of the pike that prefers slow water with abundant vegetation and cover. It is usually found in creeks or backwaters of rivers.

ESOX LUCIUS LinNaeus-Figure 66-The Northern Pike is a large predatory fish that prefers lakes and large rivers with still water. Because it is a popular sport fish, much of its present distribution is probably a result of stocking programs. It is often found in vegetation.

\section{Umbridae (Mudminnows)}

UMBRA LIMI (KIRTLAND)-Figures 13, 67-The Central Mudminnow tolerates extreme conditions. It can be found in creeks, sloughs, and wetlands, where it prefers abundant vegetation and sluggish water.
Salmonidae (Salmons)

ONCORHYNCHUS MYKISS (WALBAUM)-Figure 67-The Rainbow Trout or Steelhead is native to the Pacific Northwest, where it prefers fast-flowing and cold creeks. It is maintained in the Great Lakes region through stocking programs. It may be found in any creek that is confluent with Lake Michigan, such as Plum Creek or the Chicago Waterway System.

\section{Percopsidae (Trout-Perches)}

PERCOPSIS OMISCOMAYCUS (WALBAUM)-Figure 68-The Trout-Perch is found in the lower portions of the Des Plaines and Kankakee rivers. It prefers deep water flowing over sand and small gravel bottoms with woody debris and detritus (Trautman, 1957).

\section{Aphredoderidae (Pirate Perch)}

Aphredoderus SAYANus (Gilliams)-Figures 14, 68-The Pirate Perch is found in low-gradient creeks and the margins of large rivers of the Kankakee River system. Preferred habitat is abundant vegetation, woody debris, and detritus.

\section{Fundulidae (Killifishes)}

FUNDULUS DISPAR (AgAssiz)-Figure 68-The Starhead Topminnow is threatened. It prefers backwaters and margins of large rivers and glacial lakes and may be found in the Kankakee River system in quiet water with vegetation.

Fundulus notatus (RAFInesque)-Figures 15, 68-The Blackstripe Topminnow is abundant and found along the margins of small and large creeks alike.

\section{Poeciliidae (Livebearers)}

GAMBUSIA AFFINIS (BAIRD \& GIRARD)-Figures 16, 69-The Mosquito Fish is predominantly a southern species that is slowly spreading northward. It prefers sluggish creeks, is tolerant of poor water quality, and is confined to the Des Plaines and DuPage rivers.

The Mosquito Fish is often promoted as an effective means of mosquito control and has recently been considered as a method for combating West Nile virus. However, studies indicate that Mosquito Fish feed primarily on mosquitoes when larval abundances are high and largely ignore them the rest of the time. Furthermore, they are not more effective mosquito predators than most other native fishes, such as sunfishes and topminnows. Introductions of Mosquito Fish have been demonstrated to have a negative impact on native fishes. For reviews and additional references, see Etnier and Starnes (1993), Jenkins and Burkhead (1994), Courtenay and Meffe (1989), and Chipps and Wahl (2004).

\section{Atherinopsidae (Silversides)}

LABIDESTHES SICCULUS (COPE)-Figure 69-The Brook Silverside prefers larger rivers over sand, gravel, and detritus. It is found primarily in the lower Kankakee River.

\section{Gasterosteidae (Sticklebacks)}

Gasterosteus aculeatus LinnaEus-Figure 69-The Threespine Stickleback is native to marine and freshwater envi- 
rons of the Northern Hemisphere. It spread from Lake Ontario to the other four Great Lakes via the Welland Canal, which bypasses the natural barrier of Niagara Falls. The Will County record for this fish is from the Chicago Sanitary and Ship Canal and is probably a transient from Lake Michigan.

\section{Cottidae (Sculpins)}

Cottus BaIRDII Girard-Figure 69-The Mottled Sculpin prefers clear and cold water of small creeks. It is found in headwater creeks near Keepataw Creek Preserve. It was once present in Hickory Creek but has not been seen there in over 20 years. Isolation and destruction of its preferred habitat seems to be the explanation for its decline.

\section{Moronidae (Striped Basses)}

Morone americana (Gmelin) - Figure 70-The White Perch is native to Atlantic slope drainages and Lake Ontario but bypassed Niagara Falls via the Welland Canal. The first record in Illinois was in Lake Michigan, Chicago, in 1988 (Savitz et al., 1989). Since then, it spread down the Chicago Waterway System and now occupies the lower Des Plaines and Kankakee rivers.

MORONE CHRYSOPS (RAFINESQUE)-Figure 70-The White Bass prefers large rivers and is found in the lower Des Plaines and Kankakee rivers.

MORONE MISSISSIPPIENSIS JORDAN \& EIGENMANN-Figure 71-The Yellow Bass prefers large rivers usually in the sluggishly flowing portions. It tolerates poor water quality conditions.

\section{Centrarchidae (Sunfishes and Basses)}

AMBLOPLITES RUPESTRIS (RAFINESQUE)-Figure 72-The Rockbass may found throughout the majority of creeks and rivers. It prefers quiet margins, usually in vegetation, brush, or undercut banks.

LEPOMIS CYANELLUS RAFINESQUE-Figures 17, 73-The Green Sunfish may be found in almost any habitat and is very tolerant of poor water quality and habitat disturbance. It is one of the most common and abundant fishes.

LEPOMIS GIBBosus (Linnaeus)-Figure 74 The Pumpkinseed prefers large creeks and lake habitats where current is sluggish and vegetation abundant.

LEPOMIS GULOSUS (Cuvier) -Figure 75-The Warmouth prefers the well-vegetated backwaters of large rivers and glacial lakes. It has a natural low abundance and is sporadic.

LEPOMIS HUMILIS (Girard)-Figure 75-The Orangespotted Sunfish prefers large creeks and rivers, usually occupying undercut banks, wood jams, and overhanging vegetation. It is moderately tolerant of water quality degradation.

LEPOMIS MACROCHIRUS Rafinesque-Figure 76-The Bluegill is found in almost any habitat. This species is probably the most common sunfish caught by anglers.

LEPOMIS MICROLOPHUS (Günther) -Figure 76-The Redear Sunfish is an introduced species from the south. One occurrence was recorded from Jackson Creek before 1980. This fish is used in aquaculture to control abundance of freshwater snails.

LEPOMIS PELTASTES COPE-Figure 77-The Northern Longear Sunfish may be found in creeks and rivers in the Kankakee and lower Des Plaines watersheds. It prefers pools and undercut banks with woody debris and vegetation.

MICROPTERUS DOLOMIEU LACEPĖDE-Figure 78-The Smallmouth Bass is a highly coveted sport fish that is found in creeks and rivers with high-gradient and rock substrates. Usually, the larger the river, the larger Smallmouth Bass grow.

MICROPTERUS SALMOIDES (LACEPĖDE)-Figure 79-The Largemouth Bass is another sport fish that has a wide and abundant distribution. It is quite tolerant of water quality and habitat degradation.

POMOXIS ANNULARIS RAFINESQUE-Figure 80-The White Crappie is not as abundant as its sister species the Black Crappie $P$. nigromaculatus. It is sporadic in large rivers and lakes and prefers deep pools and backwaters with vegetation.

POMOXIS NIGROMACULATUS (Lesueur)-Figure 80-The Black Crappie prefers the pools and backwaters of large creeks and rivers. It is often targeted by anglers.

\section{Percidae (Perches and Darters)}

AMMOCRYPTA CLARA JORDAN \& MEEK-Figure 81-The Western Sand Darter is endangered. It has been collected in the Kankakee River on three occasions since 1988 and prefers moderate current over a bottom consisting completely of sand. To protect this species, sandbar formation should not be disturbed.

ETHEOSTOMA CAERULEUM STORER-Figure 81-The Rainbow Darter prefers large creeks and rivers where rock and cobble riffles form. It requires water with high oxygen content and abundant macroinvertebrate assemblages for forage. Its status is stable but, like all sensitive species, should be monitored for change.

Etheostoma eXILE (GIRARD)—Figure 81-The Iowa Darter is endangered. It prefers glacial lakes and prairie sloughs and is at the southernmost edge of its range. It is known only from Lake Renwick.

ETHEOSTOMA FLABELLARE RAFINESQUE-Figure 82-The Fantail Darter may be found in headwater to large creeks. It prefers rock and cobble riffles.

ETHEOSTOMA MICROPERCA JORDAN \& GILBERT-Figure 82The Least Darter prefers sluggish creeks, prairie sloughs, and glacial lakes, occupying areas of slow current where vegetation and detritus are abundant. It is uncommon because of lack of suitable habitat.

ETHEOSTOMA NIGRUM RAFINESQUE-Figures 18, 83-The Johnny Darter is probably the most abundant darter. It is found in almost any type of habitat and is the most tolerant of all darter species to water quality and habitat perturbation.

ETHEOSTOMA SPECTABILE (AGASSIZ)_Figure 84-The Orangethroat Darter prefers the cobble riffles of headwater and small creeks. Its status is stable but should be monitored for change.

ETHEOSTOMA ZONALE (COPE)-Figure 85-The Banded Darter is most common in large creeks and rivers in cobble and rock riffles. It spawns in the long strands of dark green filamentous algae, where it is well camouflaged. It is now absent in Hickory Creek.

PERCA FLAVESCENS (Mitchill)-Figure 85-The Yellow Perch is found in sluggish creeks, large rivers, and glacial lakes. It is usually associated with sluggish currents and dense vegetation. It is rare because of lack of suitable habitat. 


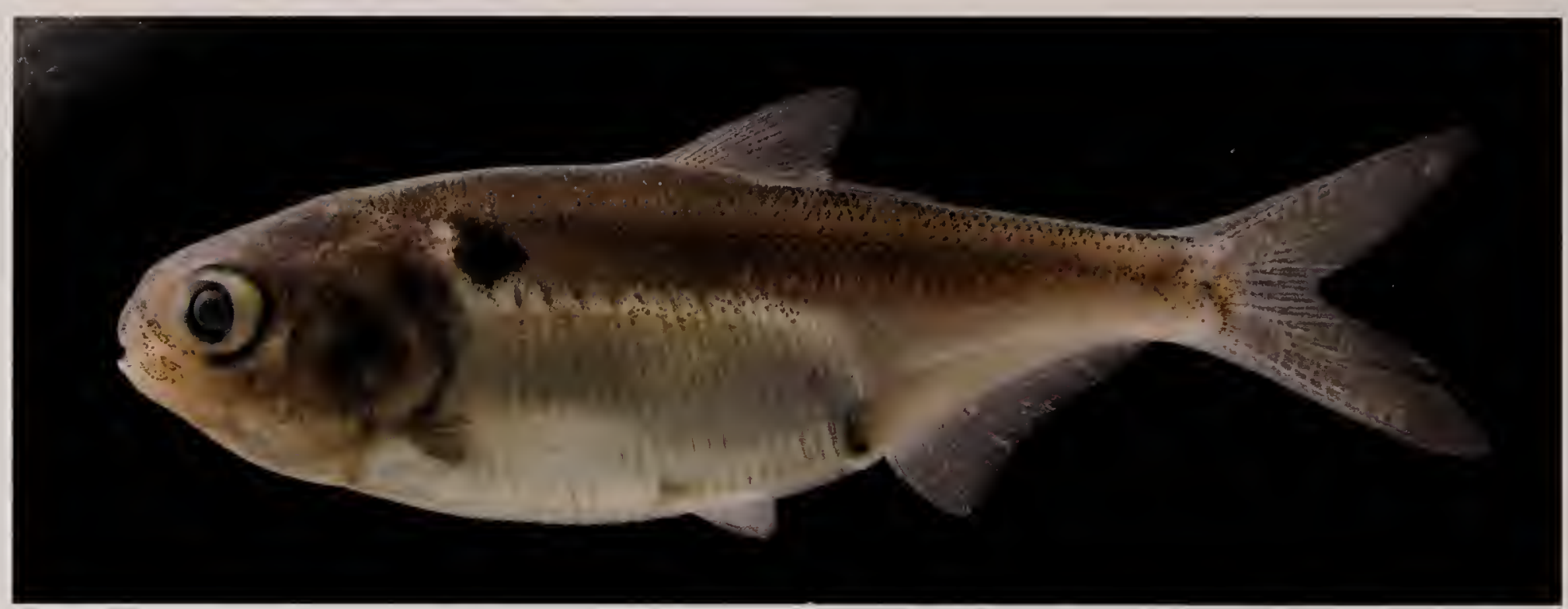

FIG. 7. Dorosoma cepedianum. Gizzard Shad. Des Plaines River at Division Street, August 2005.

PERCINA CAPRODES (DEKAY)-Figure 86-The Logperch prefers large rivers but may be found occasionally in lakes and larger creeks.

PERCINA MACUlata (GIRARD)-Figure 87-The Blackside Darter may be found in small creeks to large rivers. It prefers moderate current over sand and gravel usually with woody debris.

PERCINA PHOXOCEPHALA (NELSON) - Figure 88-The Slenderhead Darter may be found in the Kankakee River, Rock Creek, and a small section of the DuPage River. It prefers rock and cobble riffles with high oxygen content and flow. Its status is stable but should be monitored for change, as it is sensitive to sedimentation.

SANDER CANADENSIS (GRIFFITH \& SMITH)-Figure 89-The Sauger prefers deep pools and rock bars of large rivers. It is unclear if it was naturally present in Will County, but it was certainly not abundant. Its current presence is because of stocking efforts.

SANDER VITREuS (Mitchill)—Figures 19, 89-The Walleye is a coveted sport fish that occurs in large rivers and lakes. It may be found in the deep pools and rock bars of the Kankakee, Des Plaines, and DuPage rivers.

\section{Sciaenidae (Drums)}

A plodinotus gRunniens RAfinesque-Figures 20, 90-The Freshwater Drum is found in large rivers and lakes. It occurs in the DuPage, Des Plaines, and Kankakee rivers. Invasive Zebra Mussels (Dreisenna polymorpha) can make up a significant portion of its diet (pers. observ.).

\section{Gobiidae (Gobies)}

A Pollonia melanostoma (PAllas)-Figures 21, 91-The first Illinois report of the nonnative Round Goby was in the Calumet River in 1993 (Charlebois et al., 1997). It quickly spread and is now one of the most common, if not the most common, fish along the Chicago lakefront. It has been implicated in the population decline of Cottus bairdii Mottled Sculpin in Calumet Harbor (Jansen \& Jude, 2001).

\section{Fish Distribution}

\section{Distribution According to Habitat}

A particular kind of habitat in different localities within a comparatively small geographic area typically harbors the same species because of their ecological affinities. For example, fishes that are well adapted to live among vegetation are not usually found in open water. In Will County, there are five primary types of habitat: headwater creeks, creeks, rivers, ponds/lakes, and marshes/backwaters.

Headwater creeks are small and harsh environments. They often dry up or completely freeze. Only hardy fishes that are superior recolonizers are common. Typical fishes found in headwater creeks are Pimephales notatus Bluntnose Minnow, Semotilus atromaculatus Creek Chub, Catostomus commersonii White Sucker, Lepomis cyanellus Green Sunfish, Lepomis macrochirus Bluegill, Micropterus salmoides

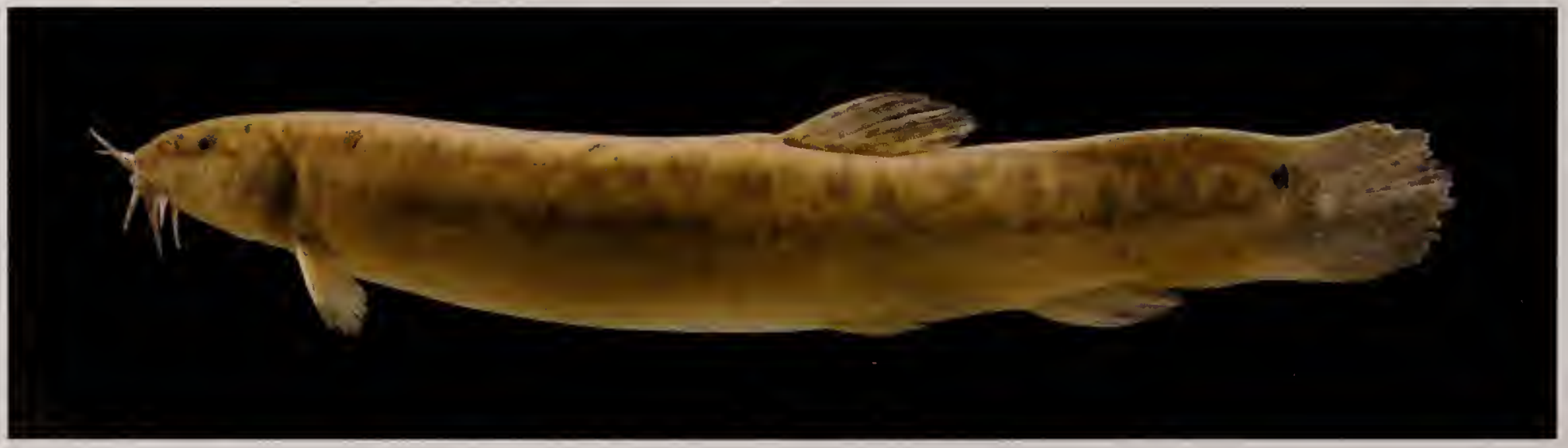

FIG. 8. Misgurnus anguillicandatus. Oriental Weatherfish. Invasive species. Des Plaines River at Division Street, August 2005. 


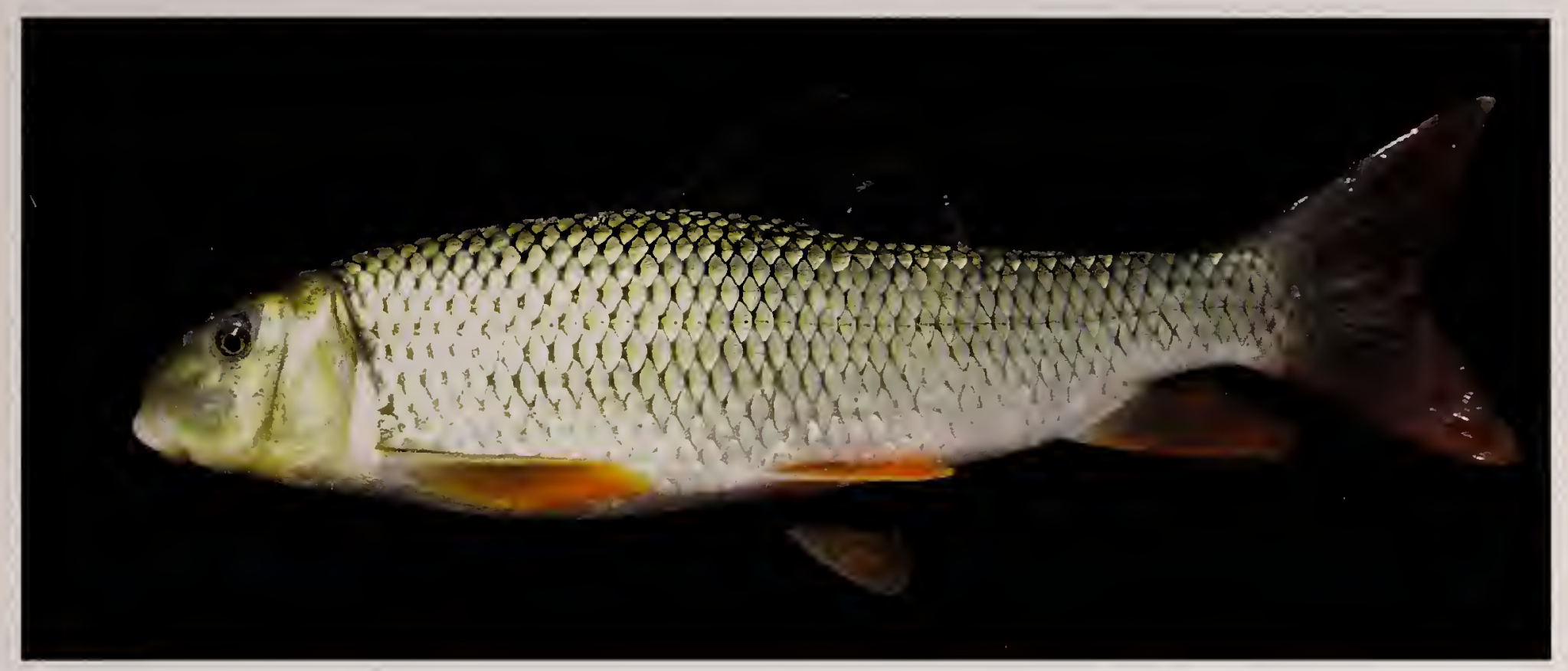

FIG. 9. Moxostoma carinatum. River Redhorse. Threatened species. Kankakee River, June 2006.

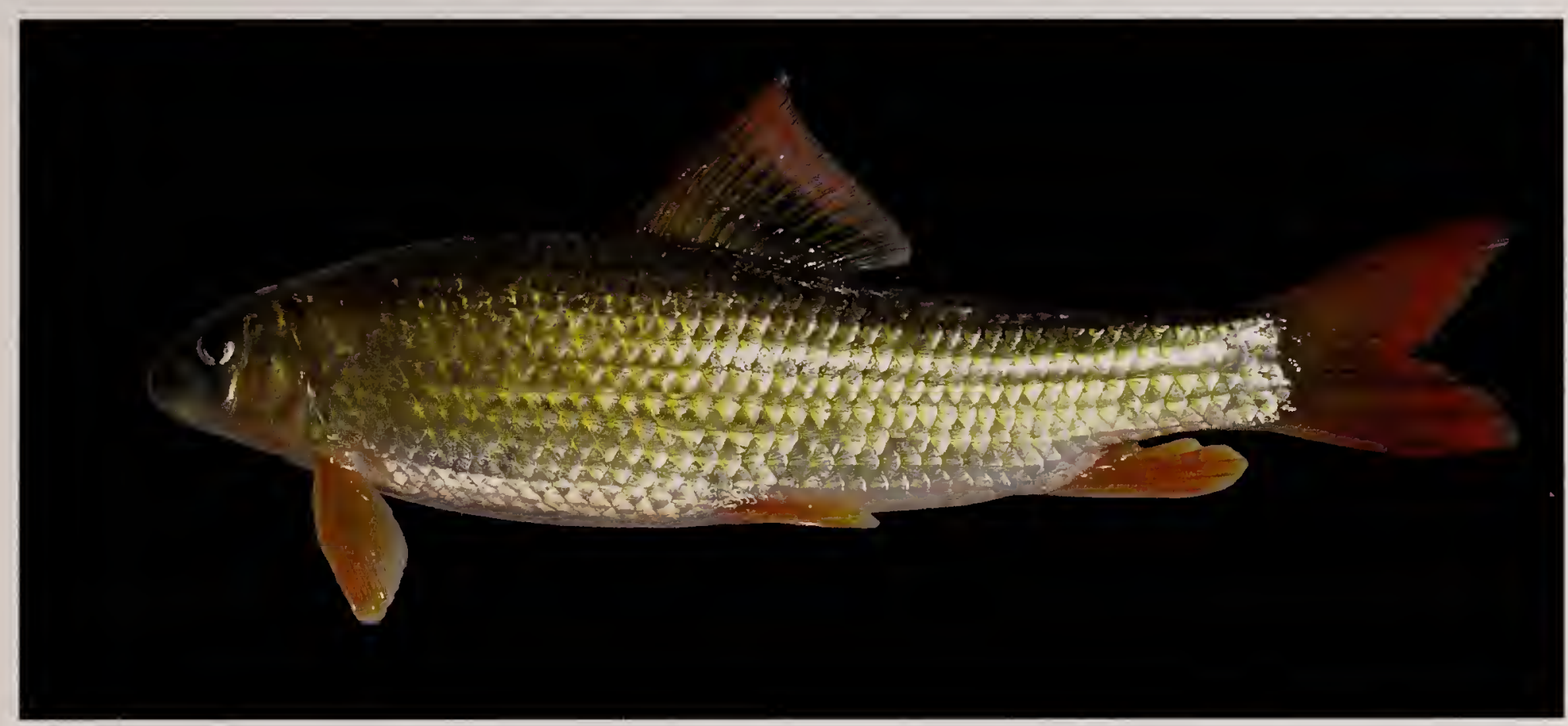

FIG. 10. Moxostoma macrolepidotum. Shorthead Redhorse. Kankakee River, June 2007.

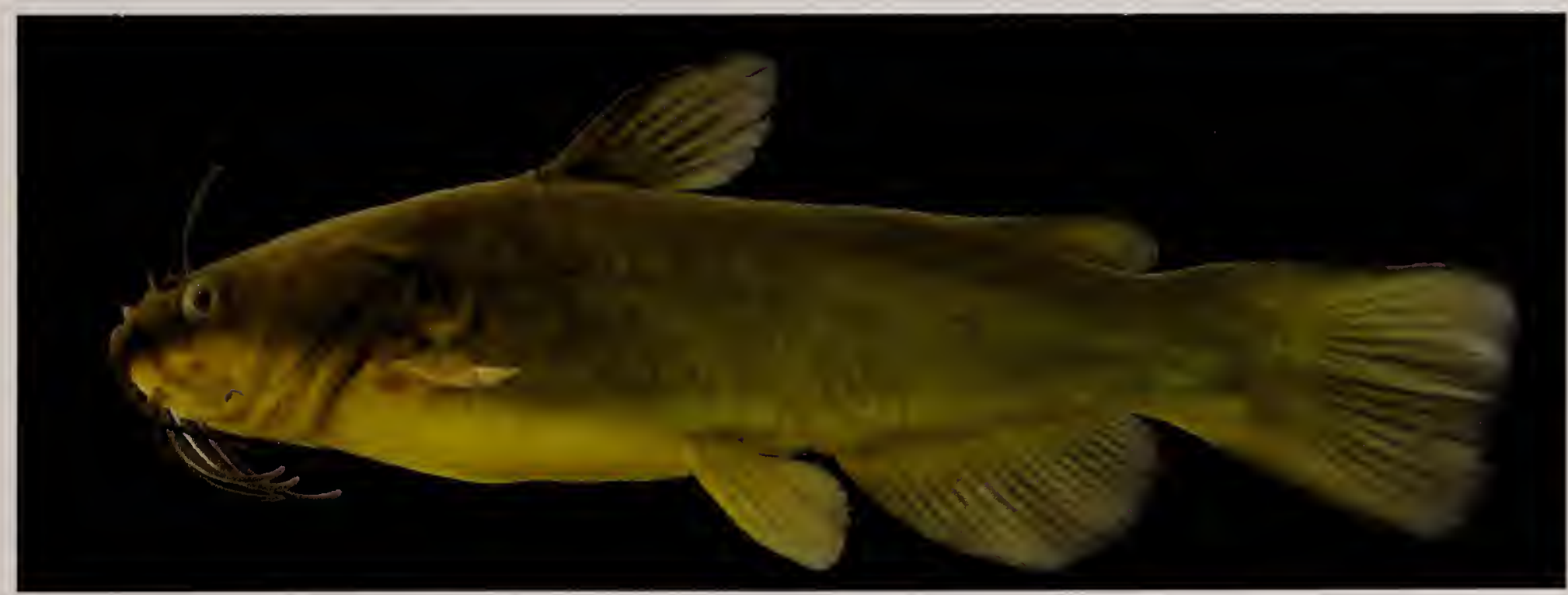

FIG. 11. Ameiurus melas. Black Bullhead. Keepataw Creek at Bluff Road, October 2005. 


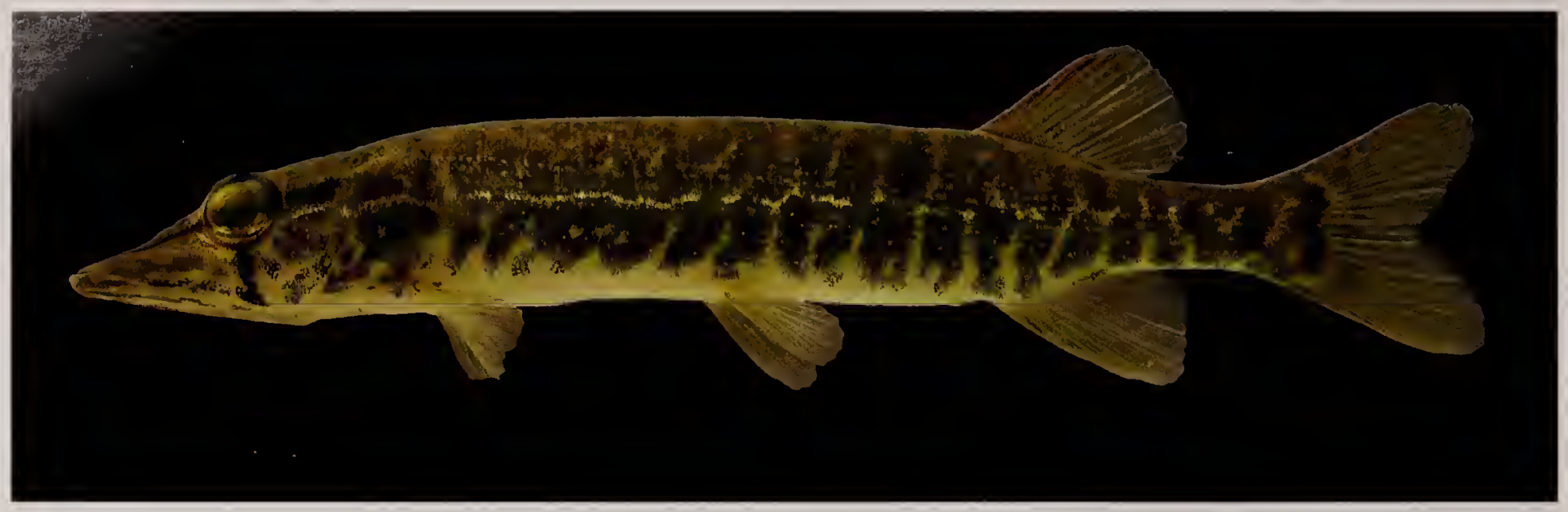

FIG. 12. Esox americanus vermiculatus. Grass Pickerel. Exline Slough at County Line Road, September 2005.

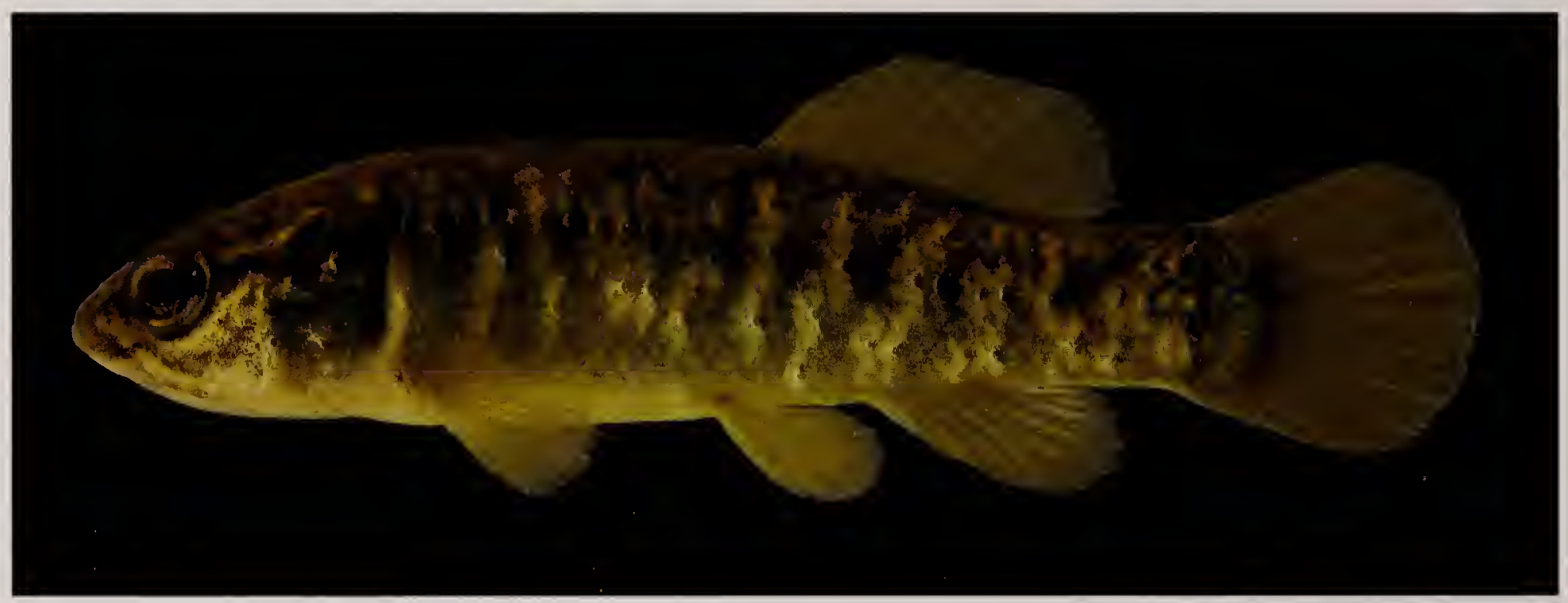

Fig. 13. Umbra limi. Central Mudminnow. Keepataw Creek at Bluff Road, October 2005.

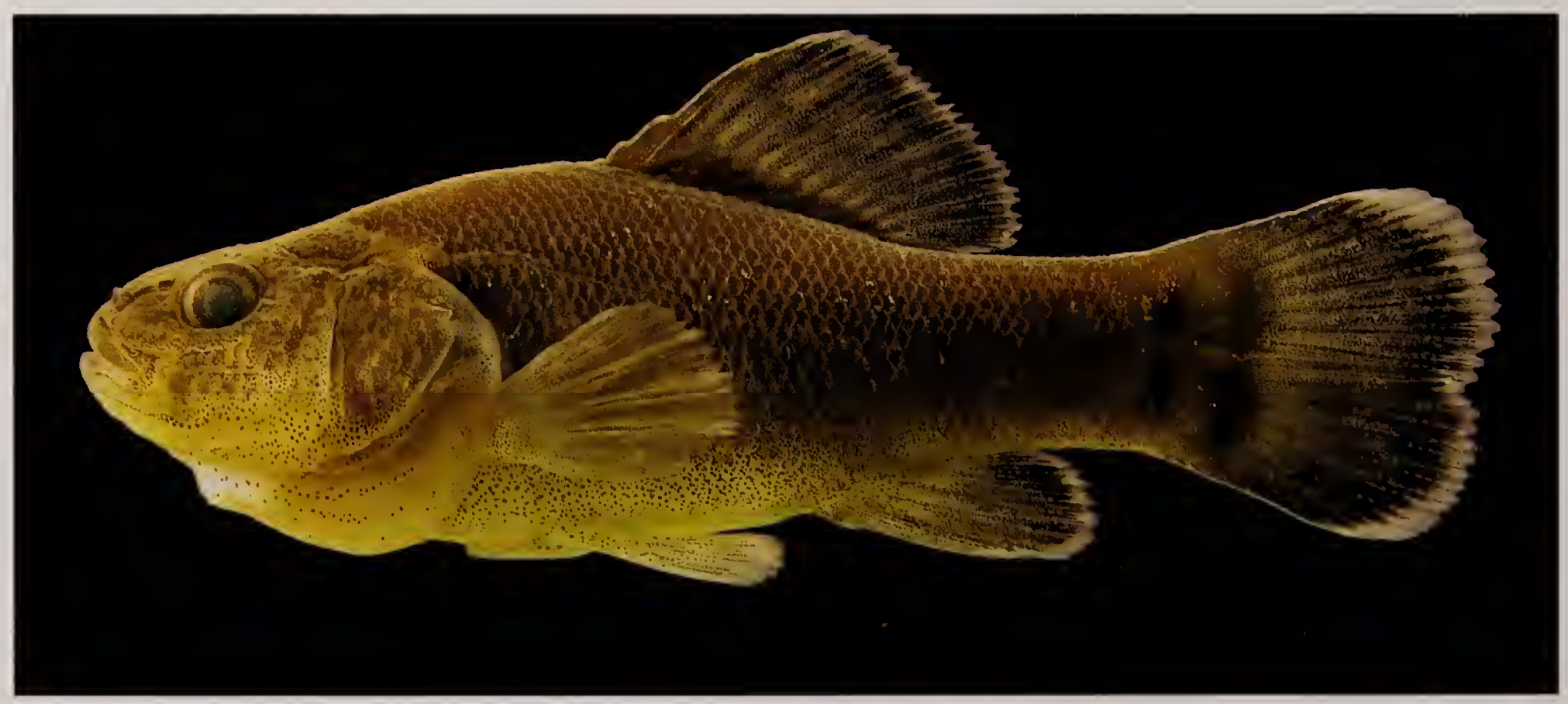

FIG. 14. Apliredoderus sayanus. Pirate Perch. Exline Slough at County Line Road, September 2005. 


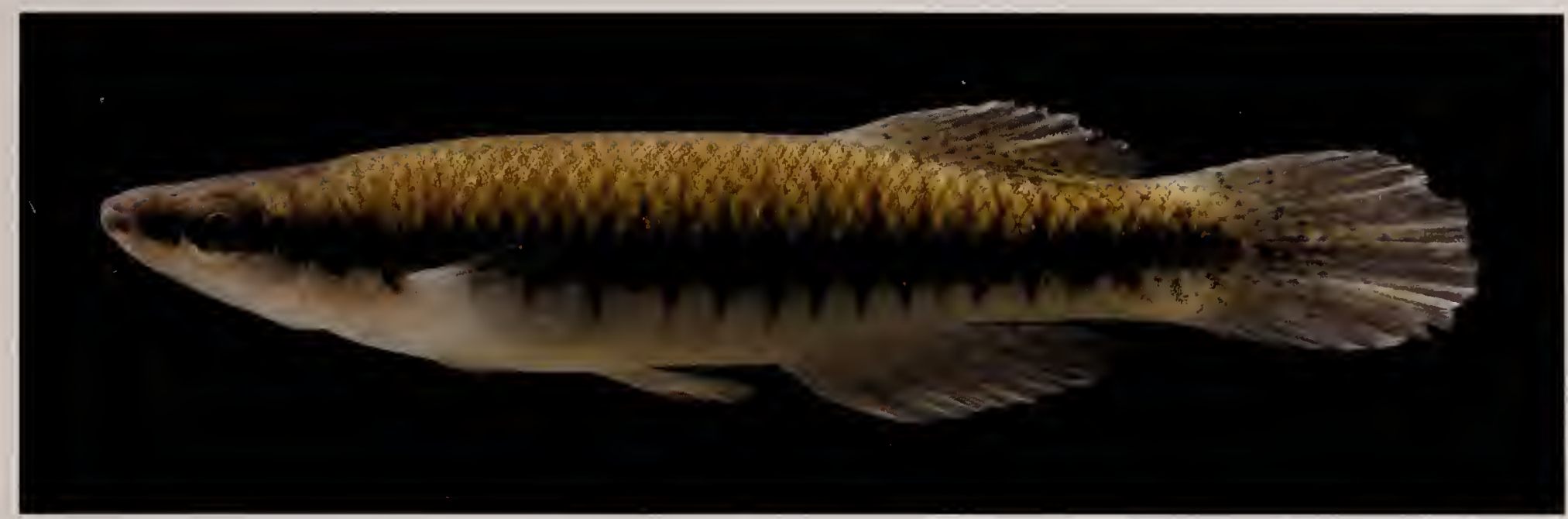

FIG. 15. Fundulus notatus. Blackstripe Topminnow. Des Plaines River at Division Street, August 2005.

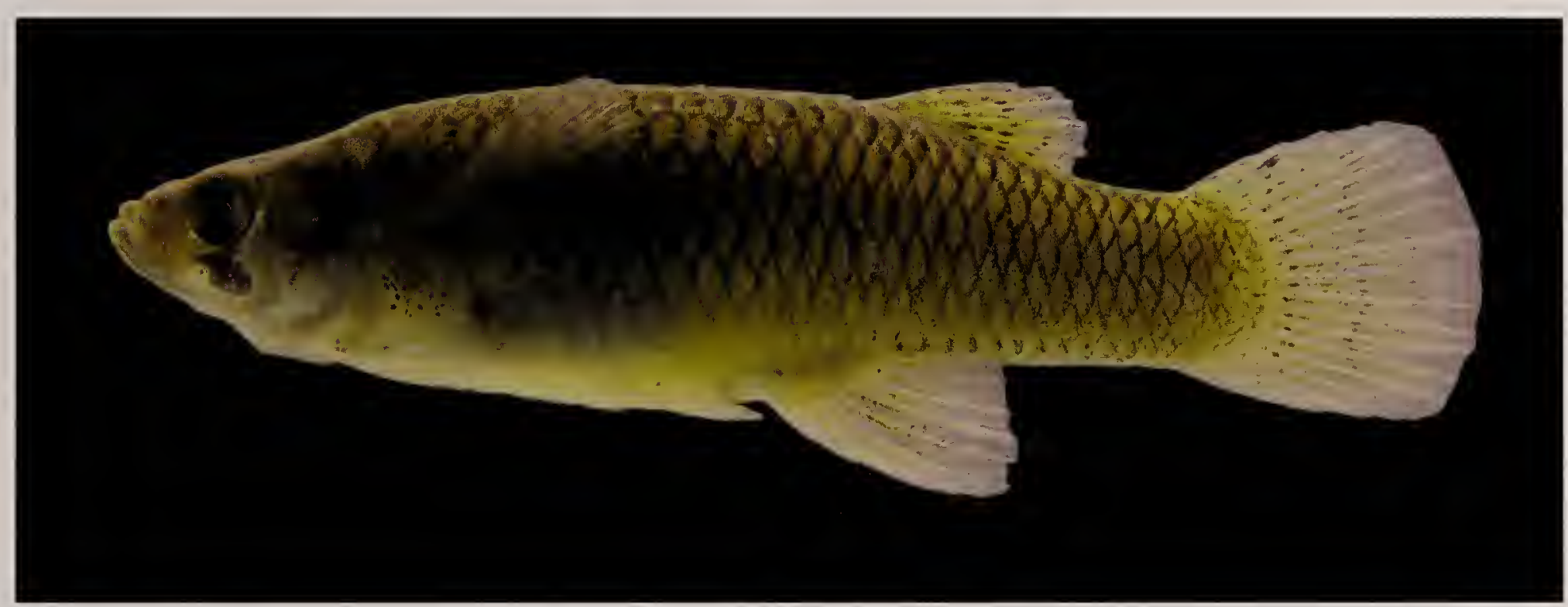

FIG. 16. Gambusia affinis. Mosquito Fish. Illinois and Michigan Canal in Lockport, October 2005.

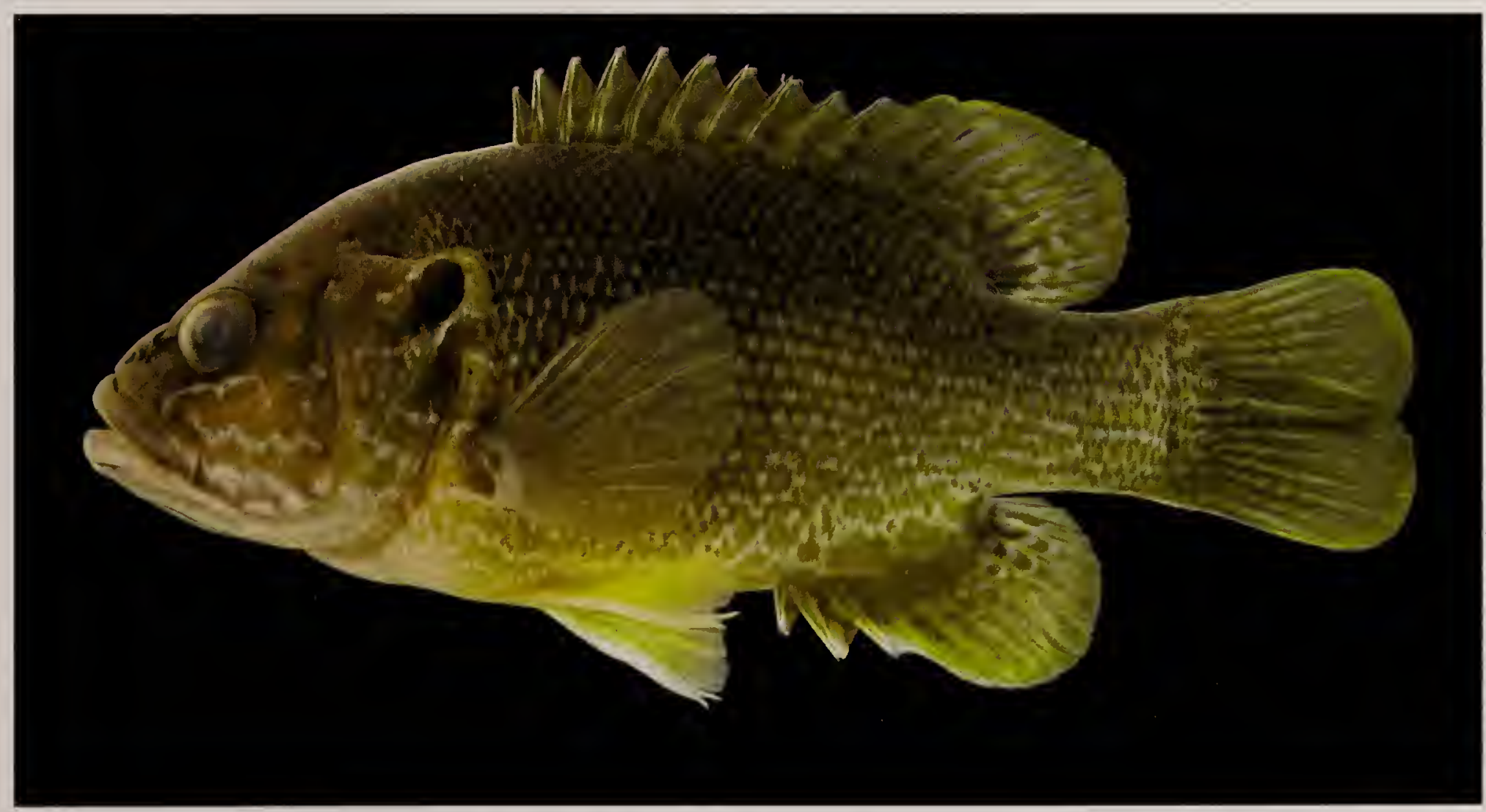

Fig. 17. Leponis cyanellus. Green Sunfish. Keepataw Creek at Bluff Road, October 2005. 


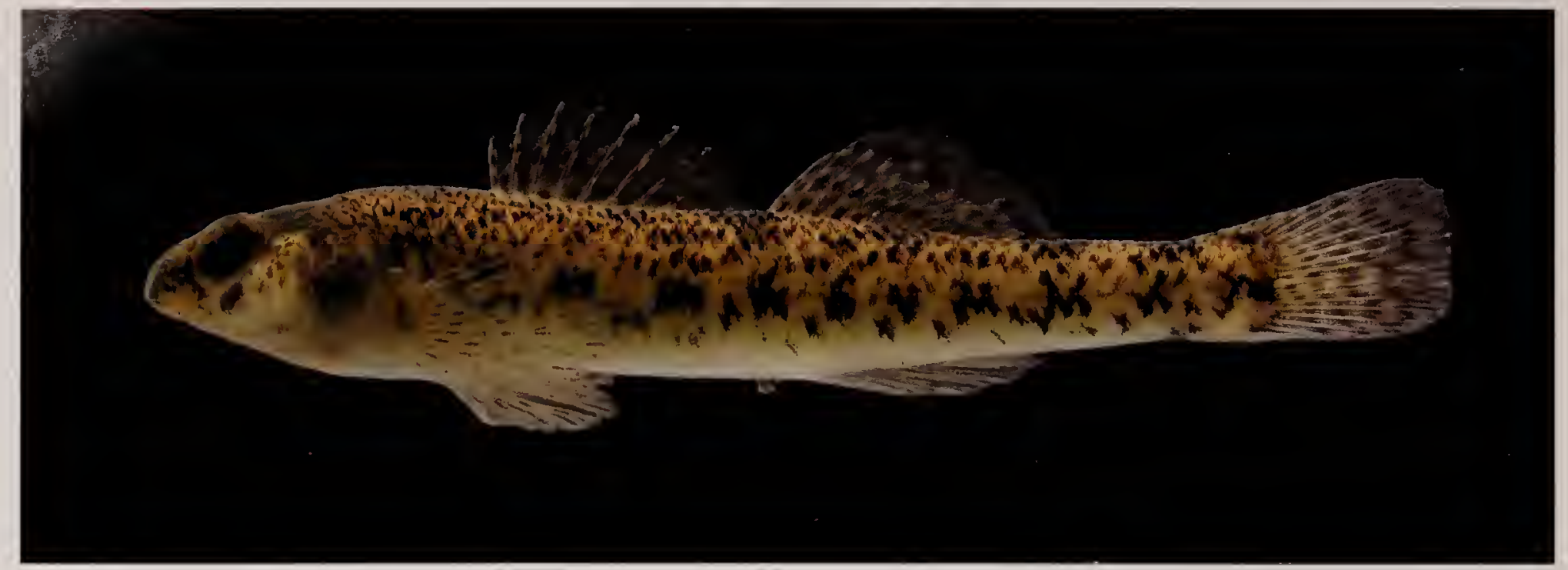

FIG. 18. Etheostoma nigrum. Johnny Darter. Long Run at High Road, August 2005.

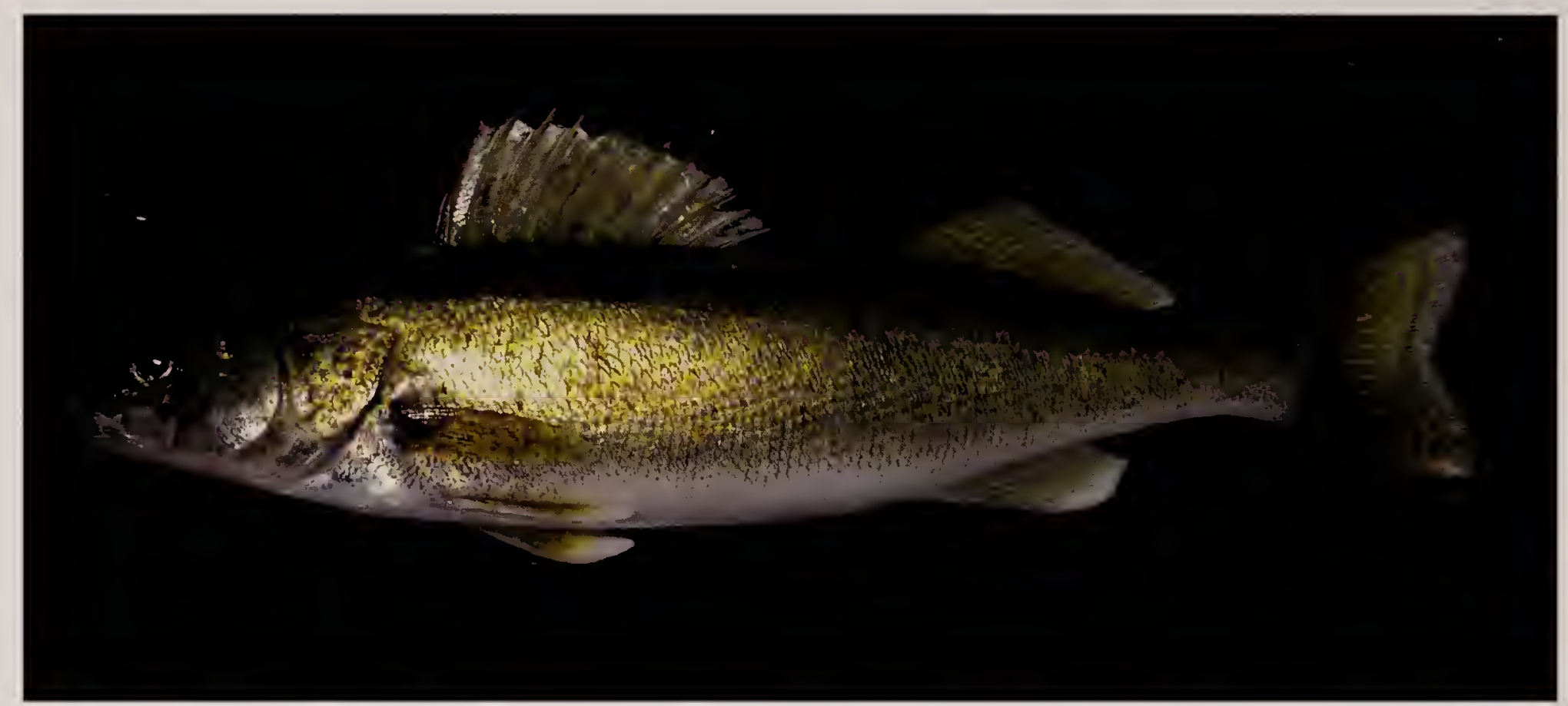

Fig. 19. Sander vitreus. Walleye. Kankakee River, June 2007.

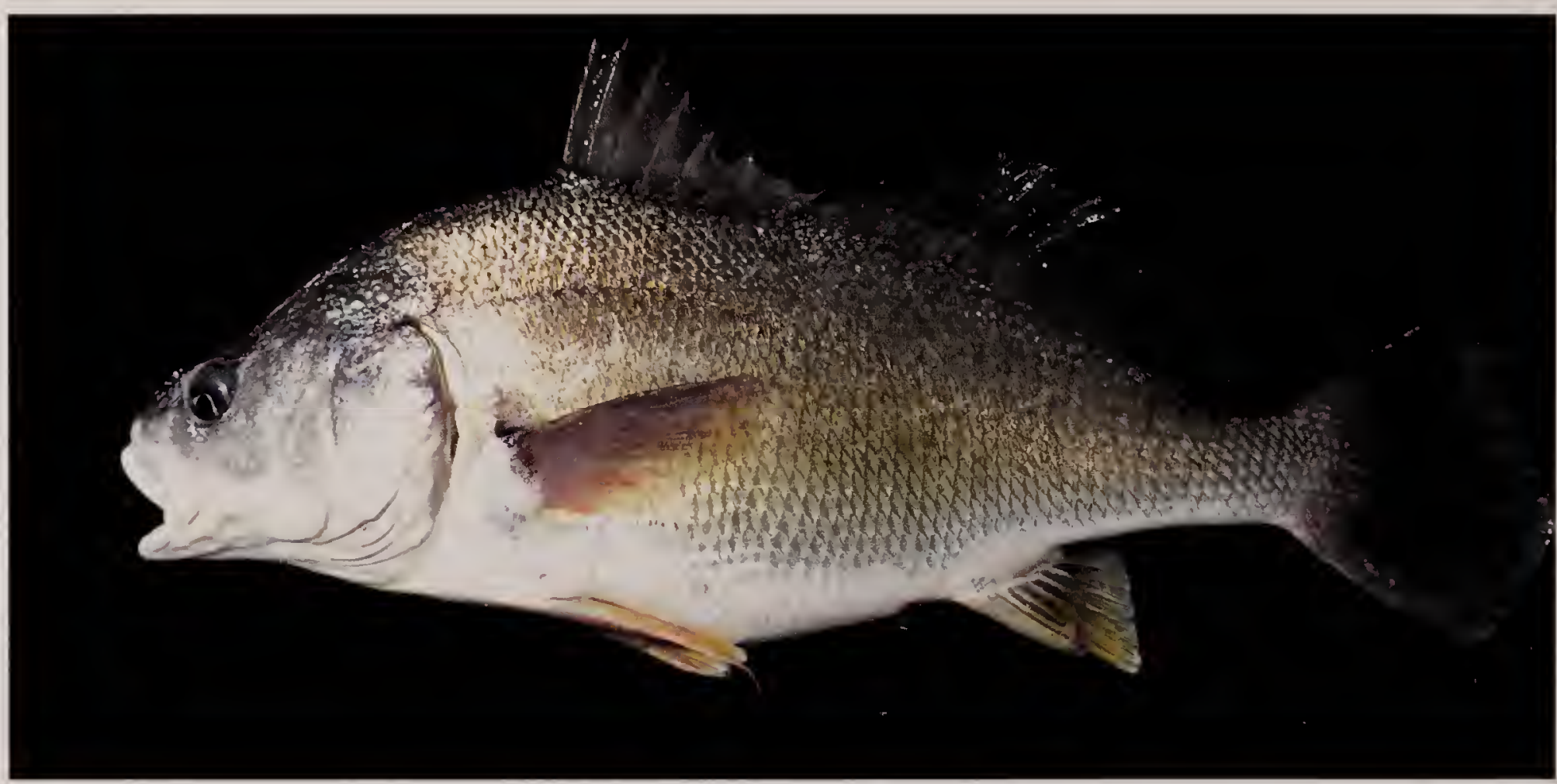

FIG. 20. Aplodinotus grunniens. Freshwater Drum. Kankakee River, June 2006. 


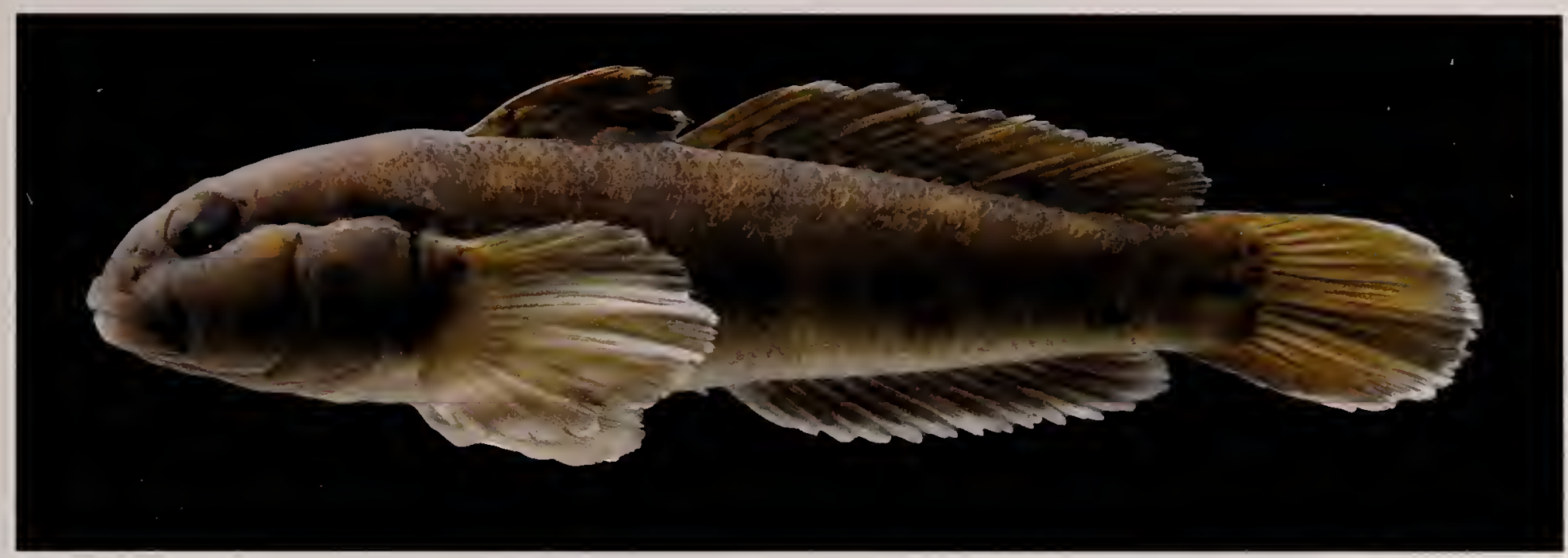

FIG. 21. Apollonia melanostoma. Round Goby. Invasive species. Des Plaines River at Division Street, August 2005.

Largemouth Bass, and Etheostoma spectabile Orangethroat Darter.

Creeks are a moderately sized aquatic habitat, and the fishes found in them are usually small to moderately sized. Microhabitats can vary, from swift flows over rocks to almost stagnant pools. Fishes in creeks can be either microhabitat specialists or generalists. Typical fishes found in creeks are $P$. notatus, L. cyanellus, L. macrochirus, C. commersonii, Ameiurus melas Black Bullhead, Ameinrus natalis Yellow Bullhead, Notropis stramineus Sand Shiner, Notropis dorsalis Bigmouth Shiner, S. atromaculatus, Luxilus chrysocephalus Striped Shiner, Ploxinus erythrogaster Southern Redbelly Dace, Campostoma anomalum Central Stoneroller, Nocomis biguttatus Hornyhead Chub, Etheostoma nigrum Johnny Darter, and E. spectabile.
Rivers provide the largest source of aquatic habitats in Will County. Rivers are where one finds the largest fishes, such as Ictiobus spp. Buffalos, Carpiodes spp. Carpsuckers, Moxostoma spp. Redhorses, Ictalurus punctatus Channel Catfish, Pylodictis olivaris Flathead Catfish, M. salmoides, Micropterus dolomieu Smallmouth Bass, Sander vitreus Walleye, and Aplodinotus grunniens Freshwater Drum, although small to moderately sized fishes are present as well, like Percina caprodes Logperch.

The dominant fishes in ponds and lakes are those that are poorly adapted to swimming against currents. They also spend much of their time in the vegetation, looking for food or hiding from predators. Typical fishes found in ponds and lakes are L. macrochirus, Lepomis gibbosus Pumpkinseed, M. salmoides, Pomoxis nigromaculatus Black Crappie, Pomoxis

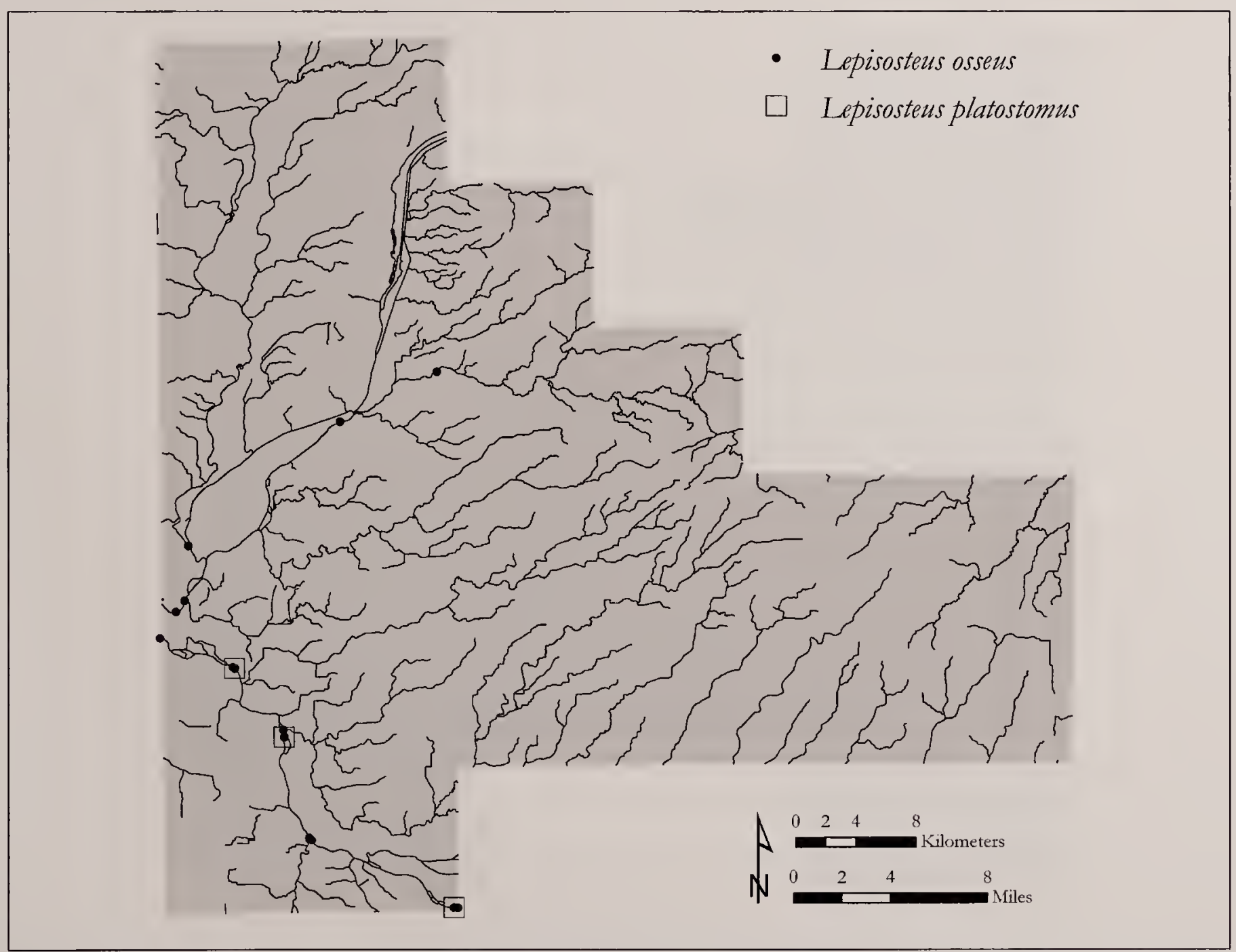

Fig. 22. Distribution of Lepisosteus osseus (Longnose Gar) and Lepisosteus platostomus (Shortnose Gar) in Will County, Illinois. 


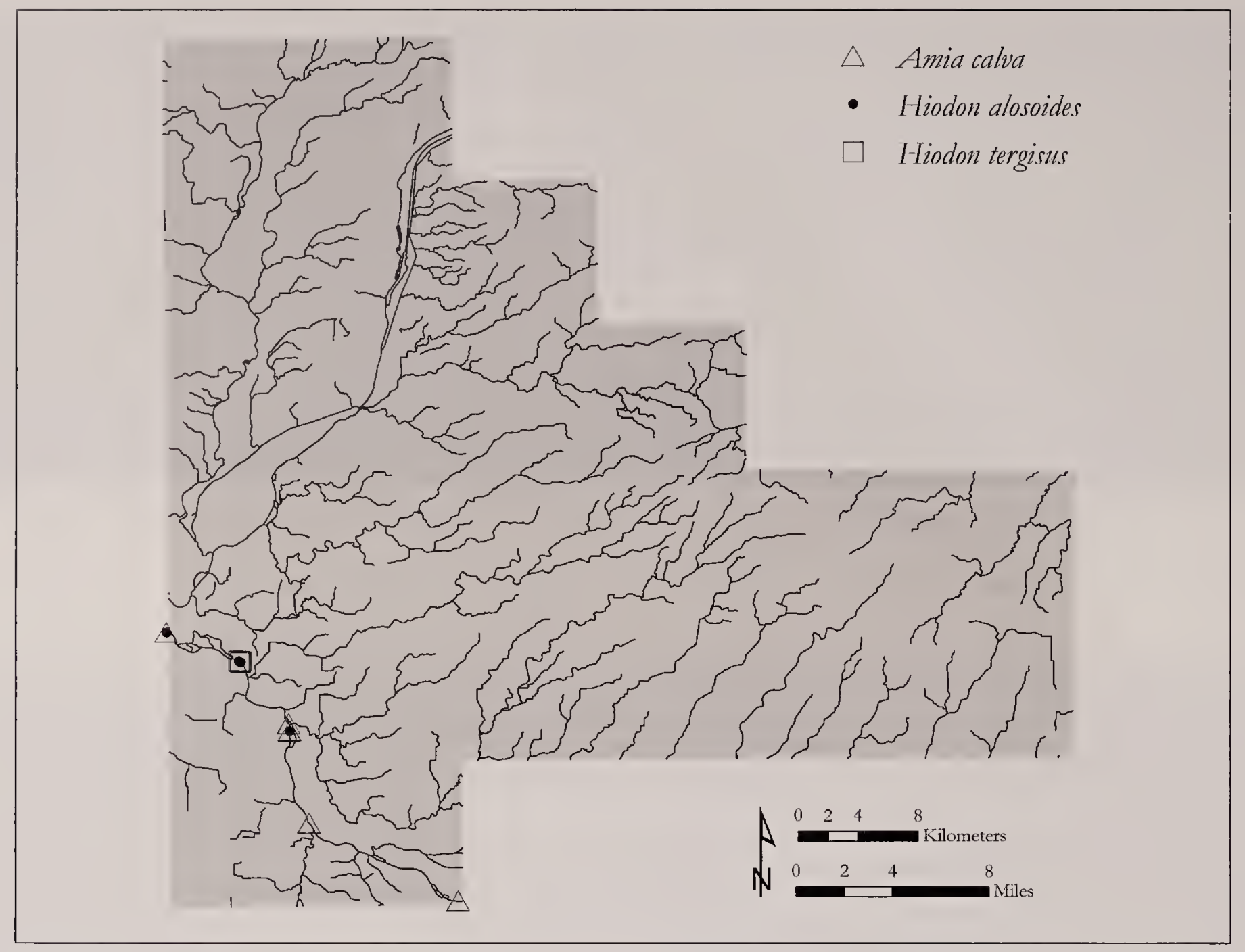

Fig. 23. Distribution of Amia calva (Bowfin), Hiodon alosoides (Goldeye), and Hiodon tergisus (Mooneye) in Will County, Illinois.

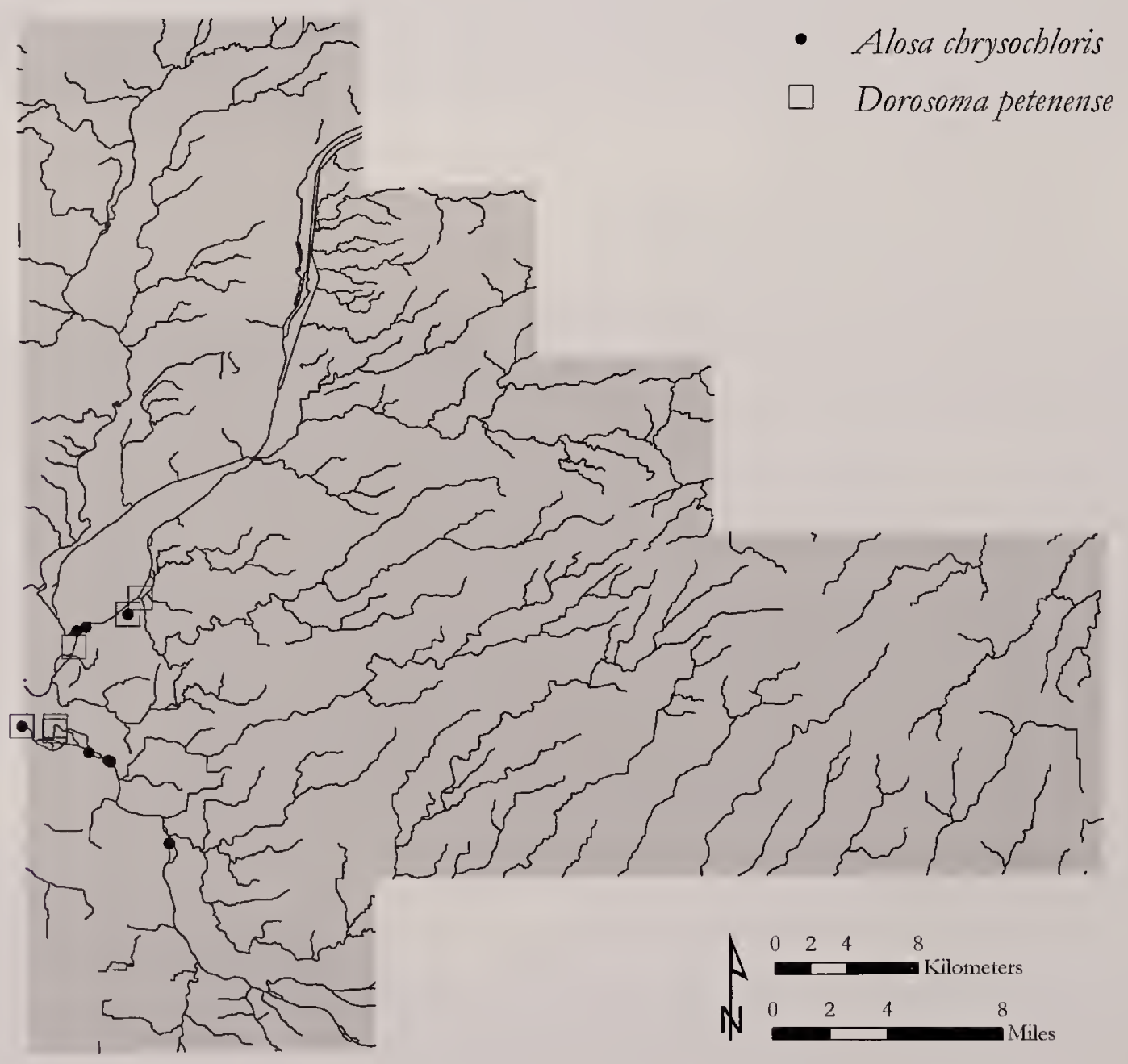

FIG. 24. Distribution of Alosa clirysochloris (Skipjack Herring) and Dorosoma petenense (Threadfin Shad) in Will County, Illinois. 


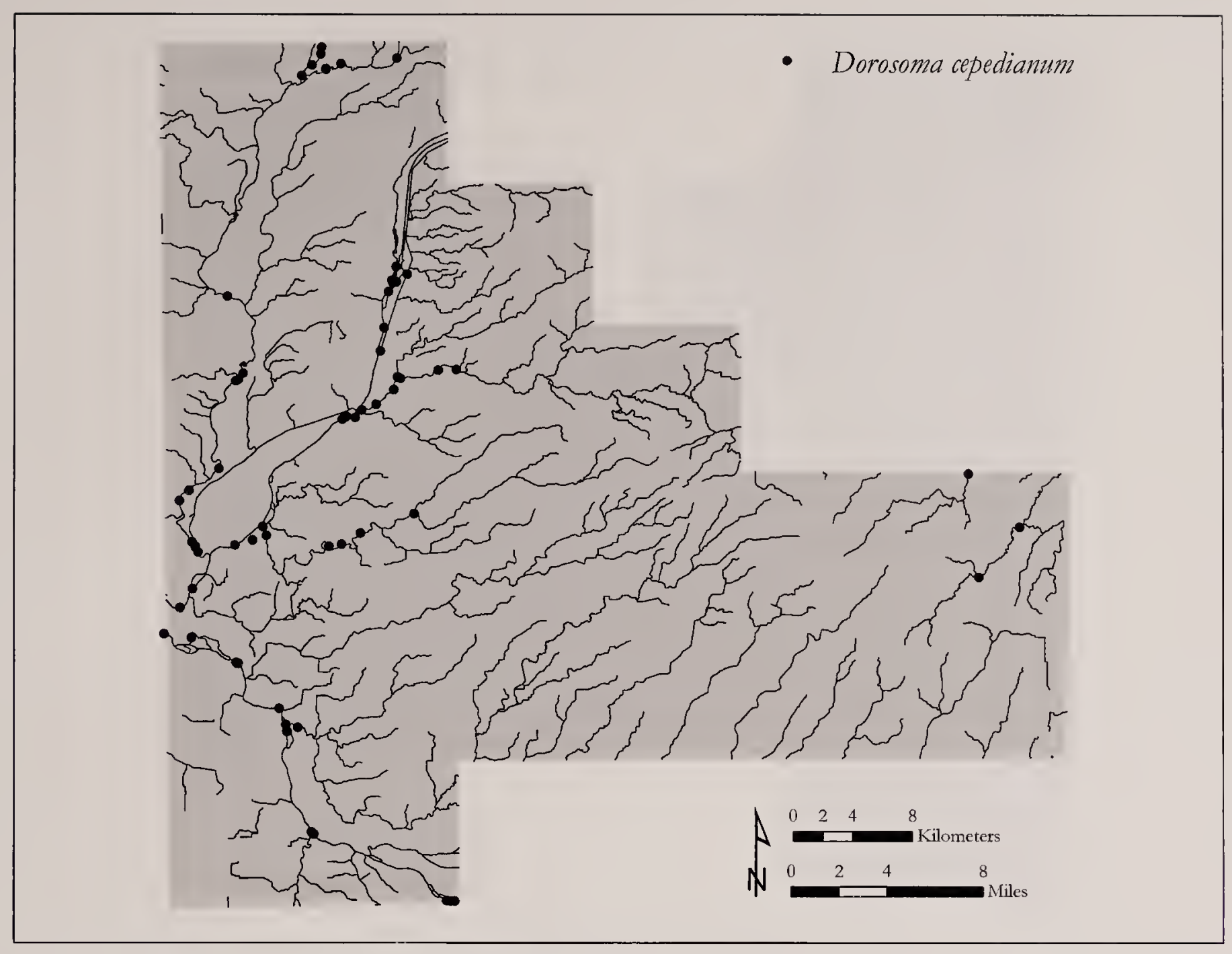

FIG. 25. Distribution of Dorosoma cepedianum (Gizzard Shad) in Will County, Illinois.

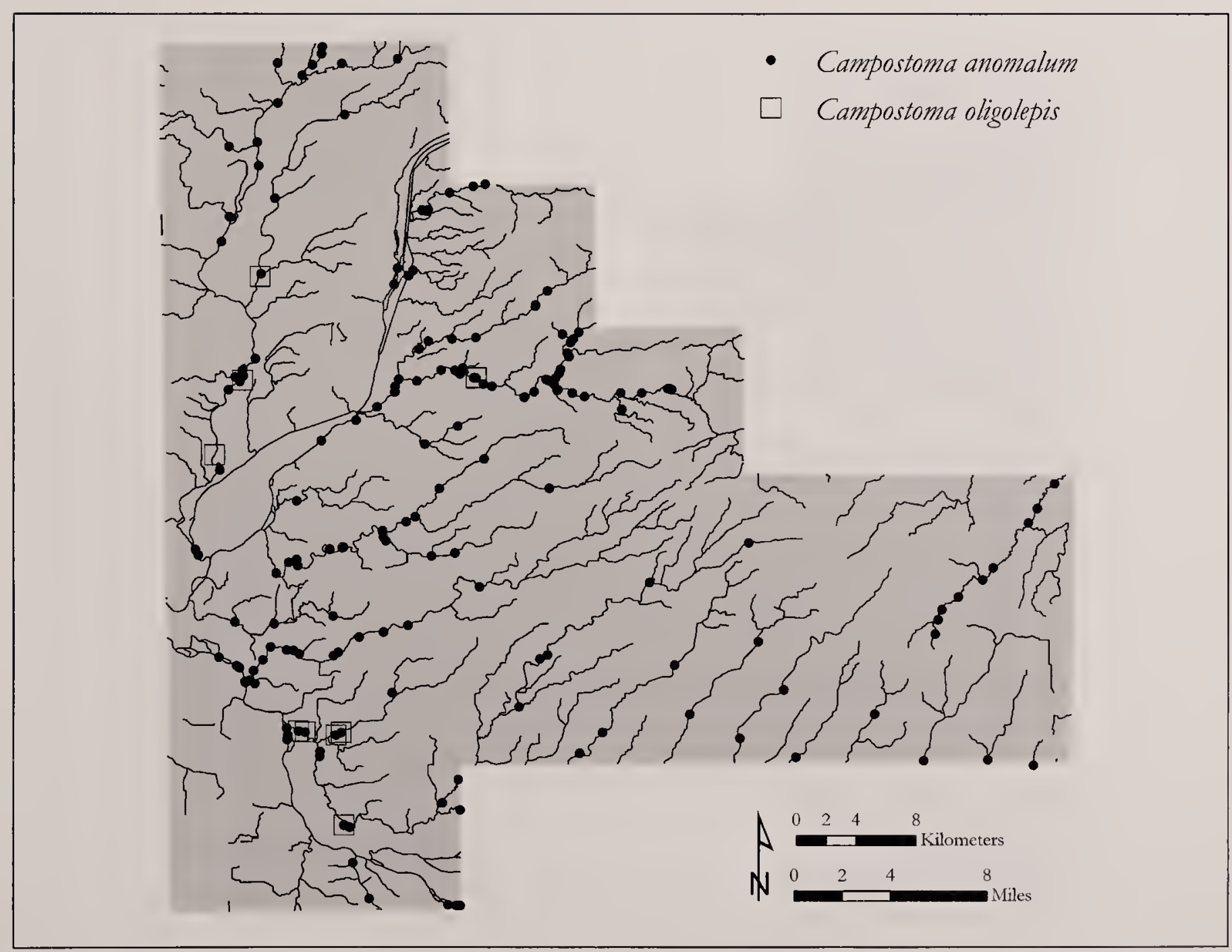

FIG. 26. Distribution of Campostoma anomalum (Central Stoneroller) and Campostoma oligolepis (Largescale Stoneroller) in Will County, Illinois. 


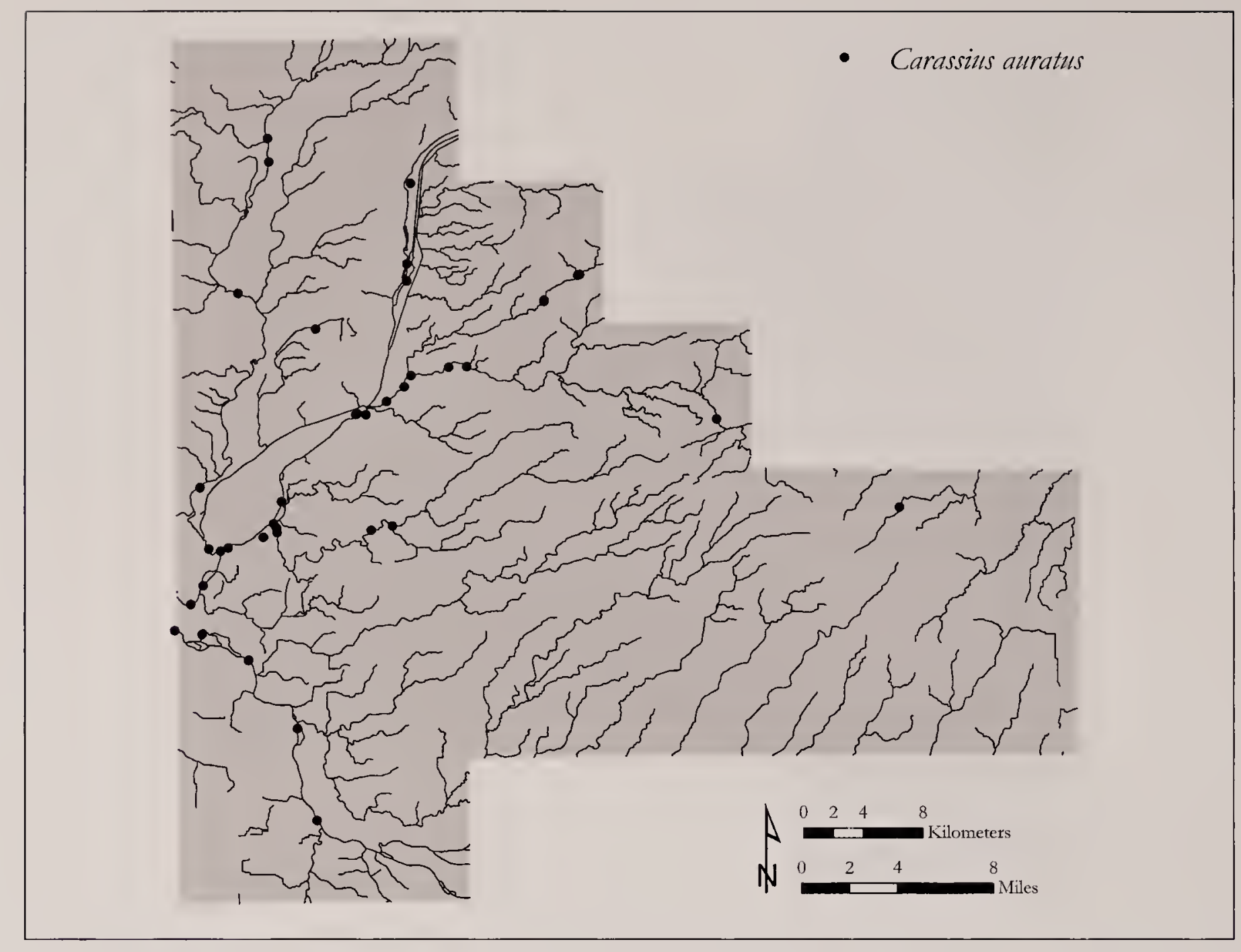

FIG. 27. Distribution of Carassius auratus (Goldfish) in Will County, Illinois.

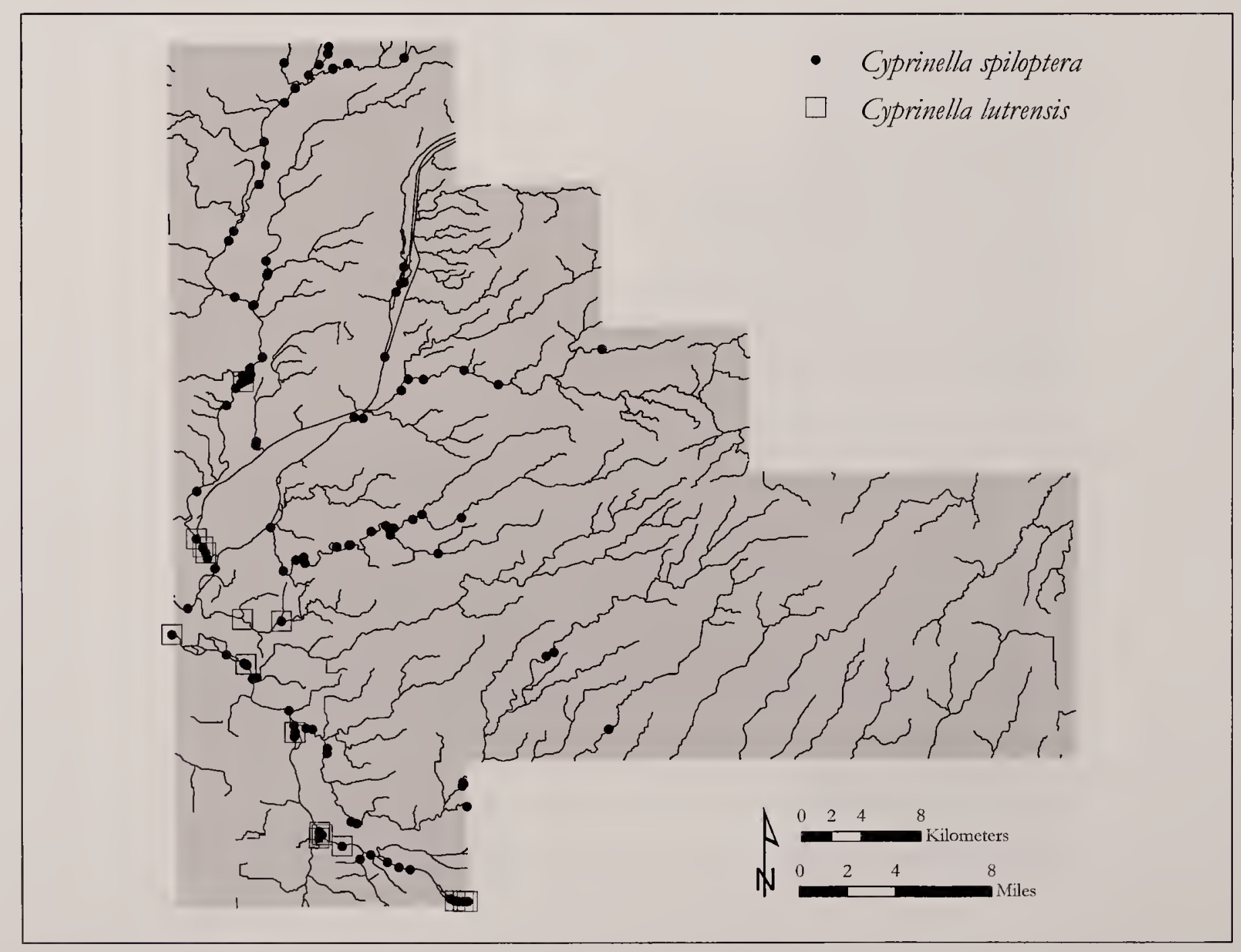

FIG. 28. Distribution of Cyprinella lutrensis (Red Shiner) and Cyprinella spiloptera (Spotfin Shiner) in Will County, Illinois. 


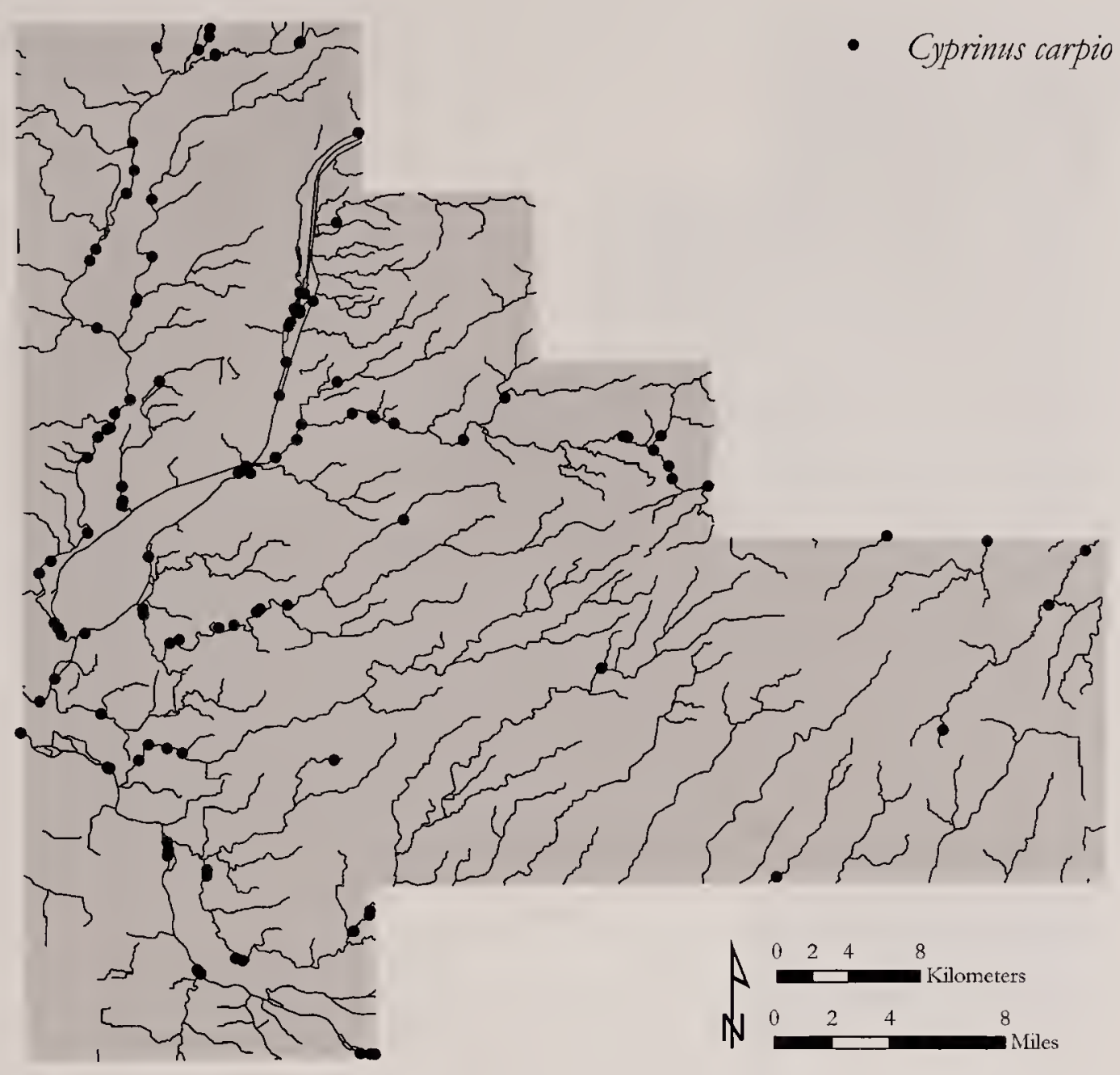

FIG. 29. Distribution of Cyprinus carpio (Common Carp) in Will County, Illinois.

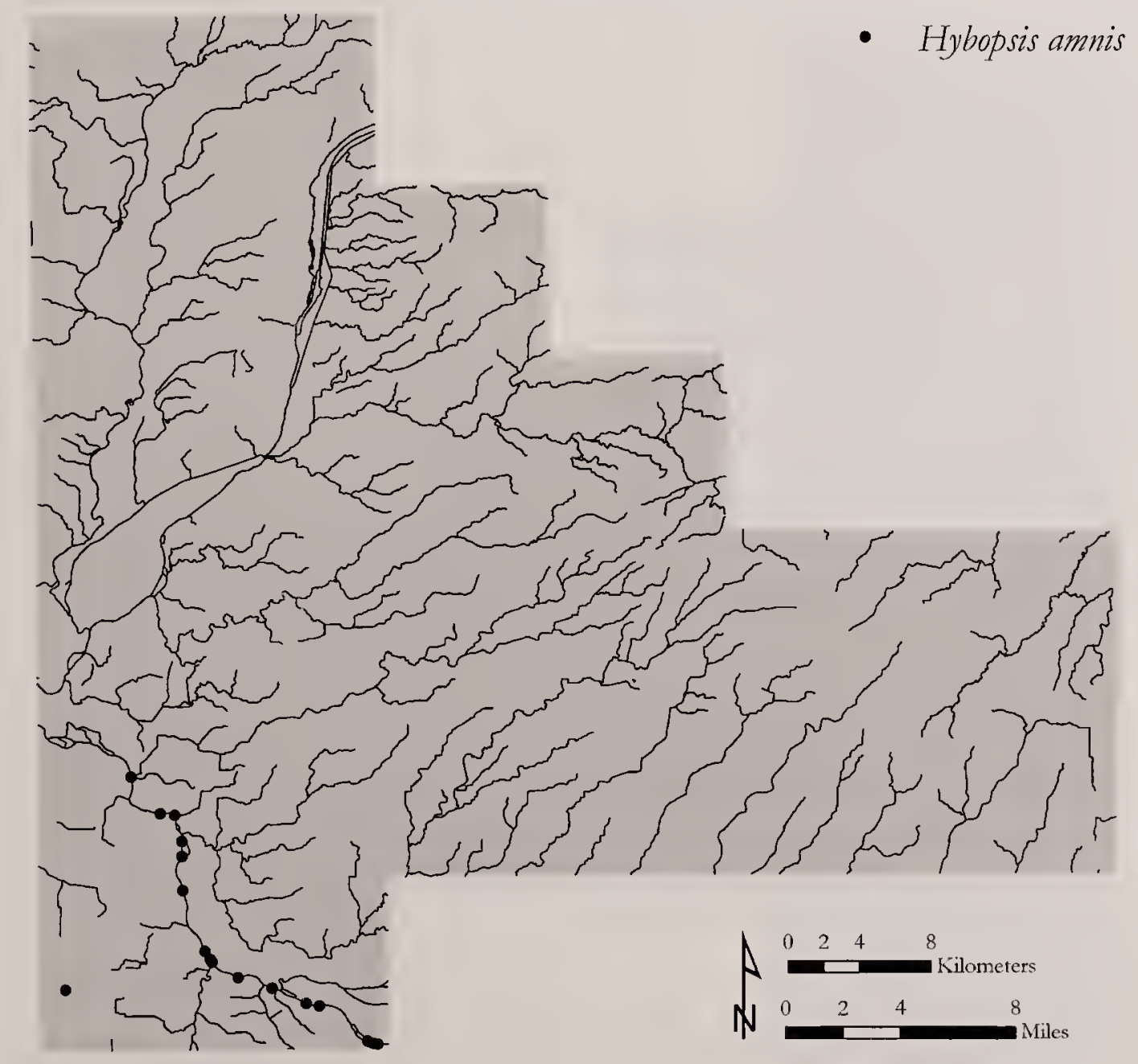

FIG. 30. Distribution of Hybopsis amnis (Pallid Shiner) in Will County, Illinois. 


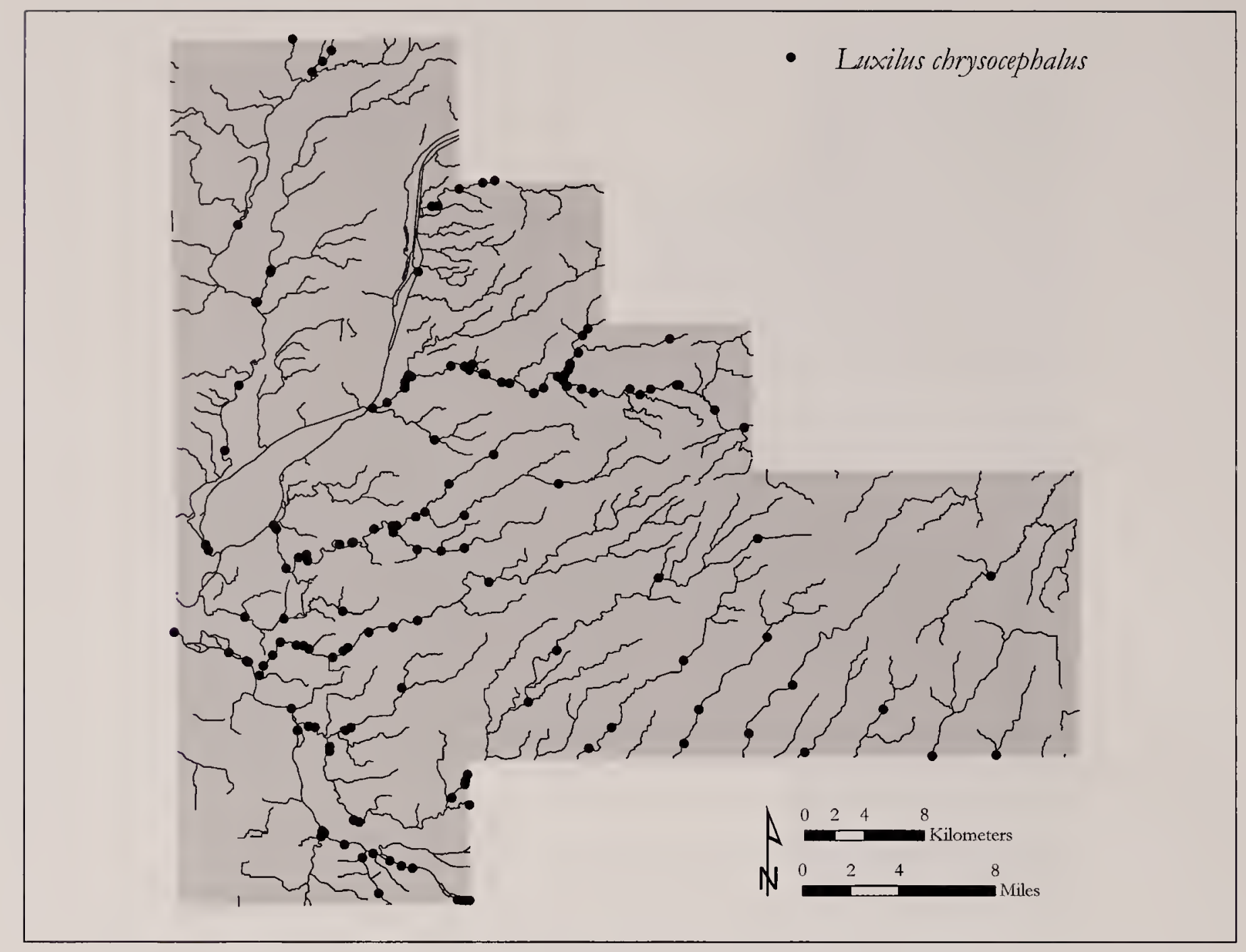

Fig. 31. Distribution of Luxilus chrysocephalus (Striped Shiner) in Will County, Illinois.

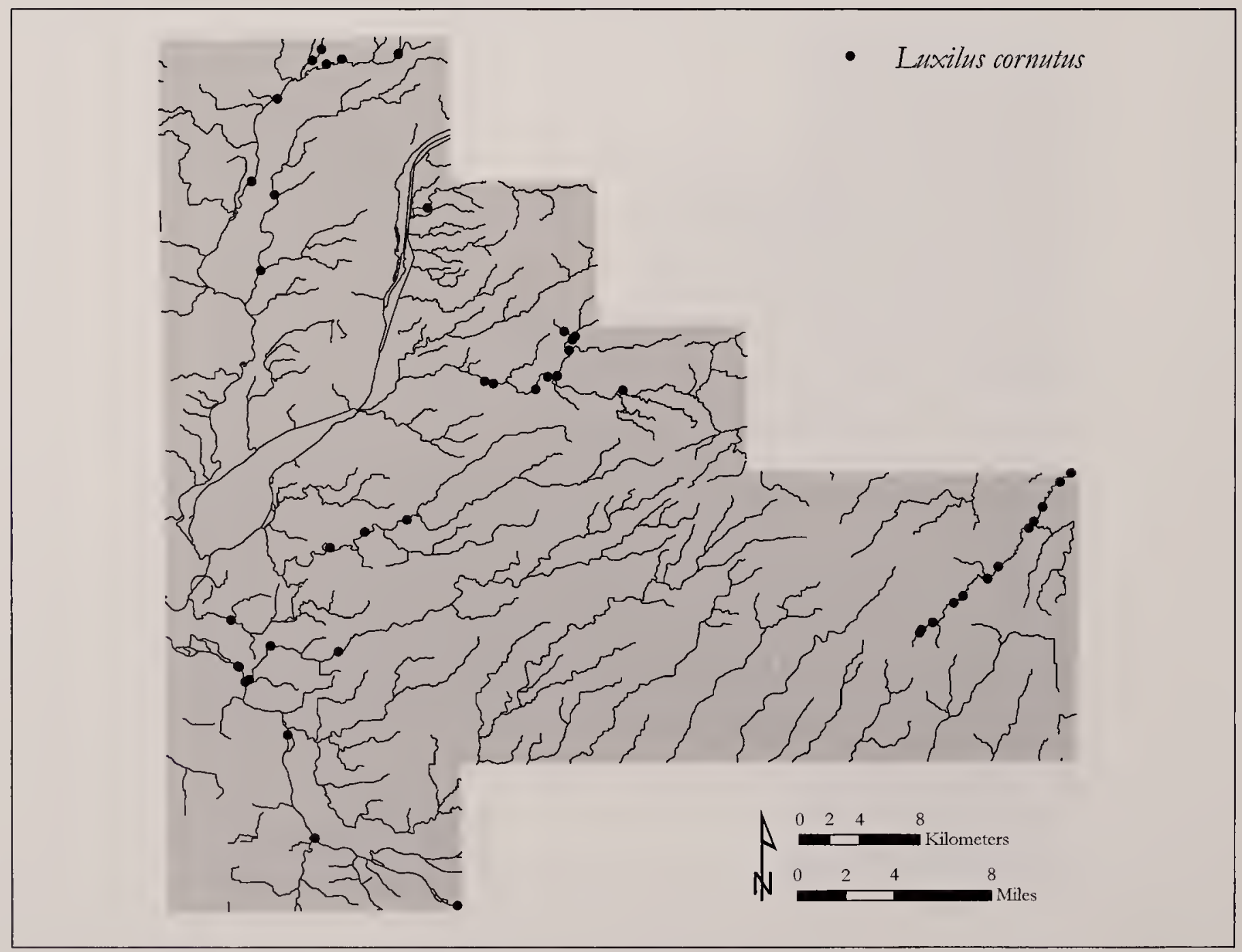

FIG. 32. Distribution of Luxilus cornutus (Common Shiner) in Will County, Illinois. 


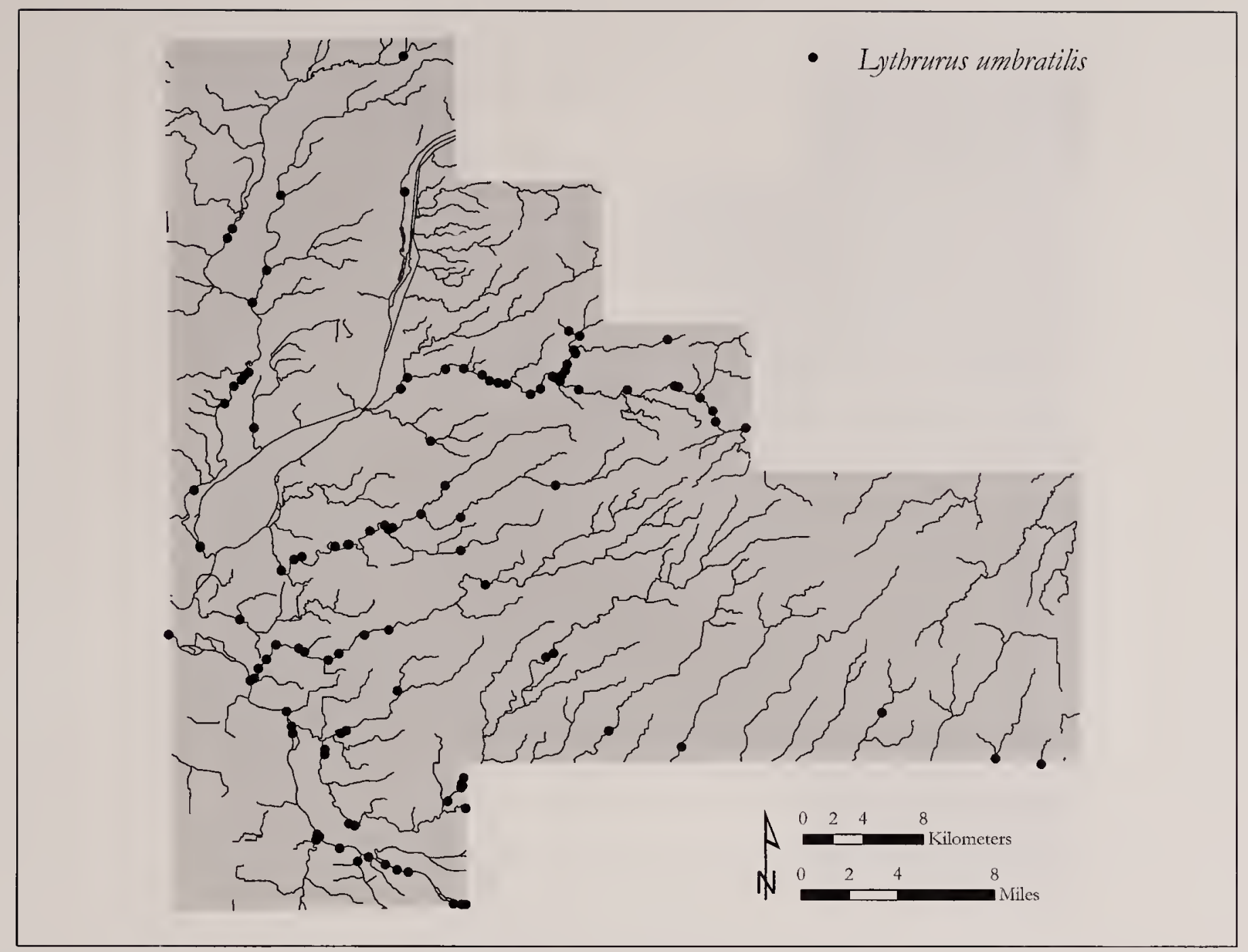

FIG. 33. Distribution of Lythrurus umbratilis (Redfin Shiner) in Will County, Illinois.

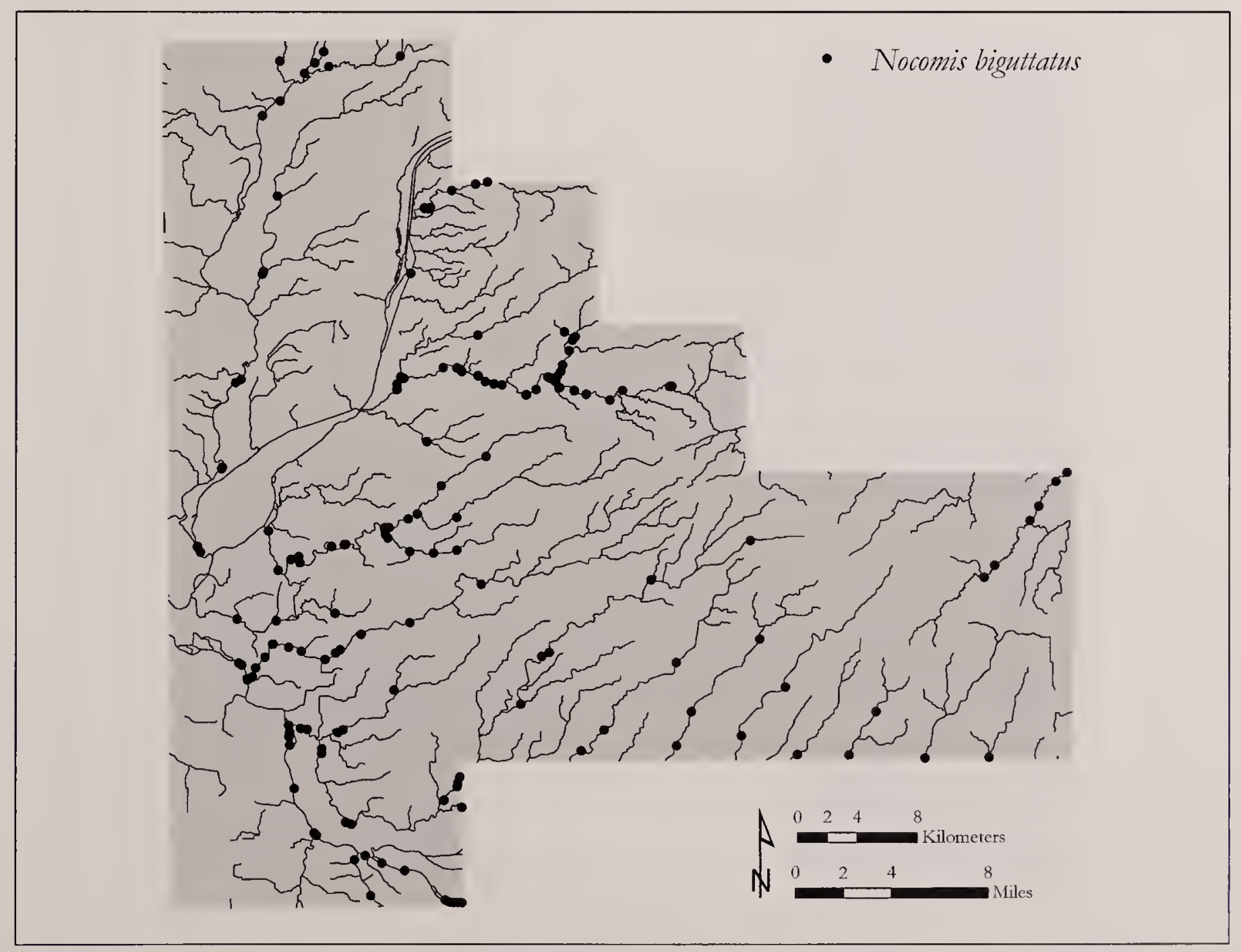

FIG. 34. Distribution of Nocomis biguttatus (Hornyhead Chub) in Will County, Illinois. 


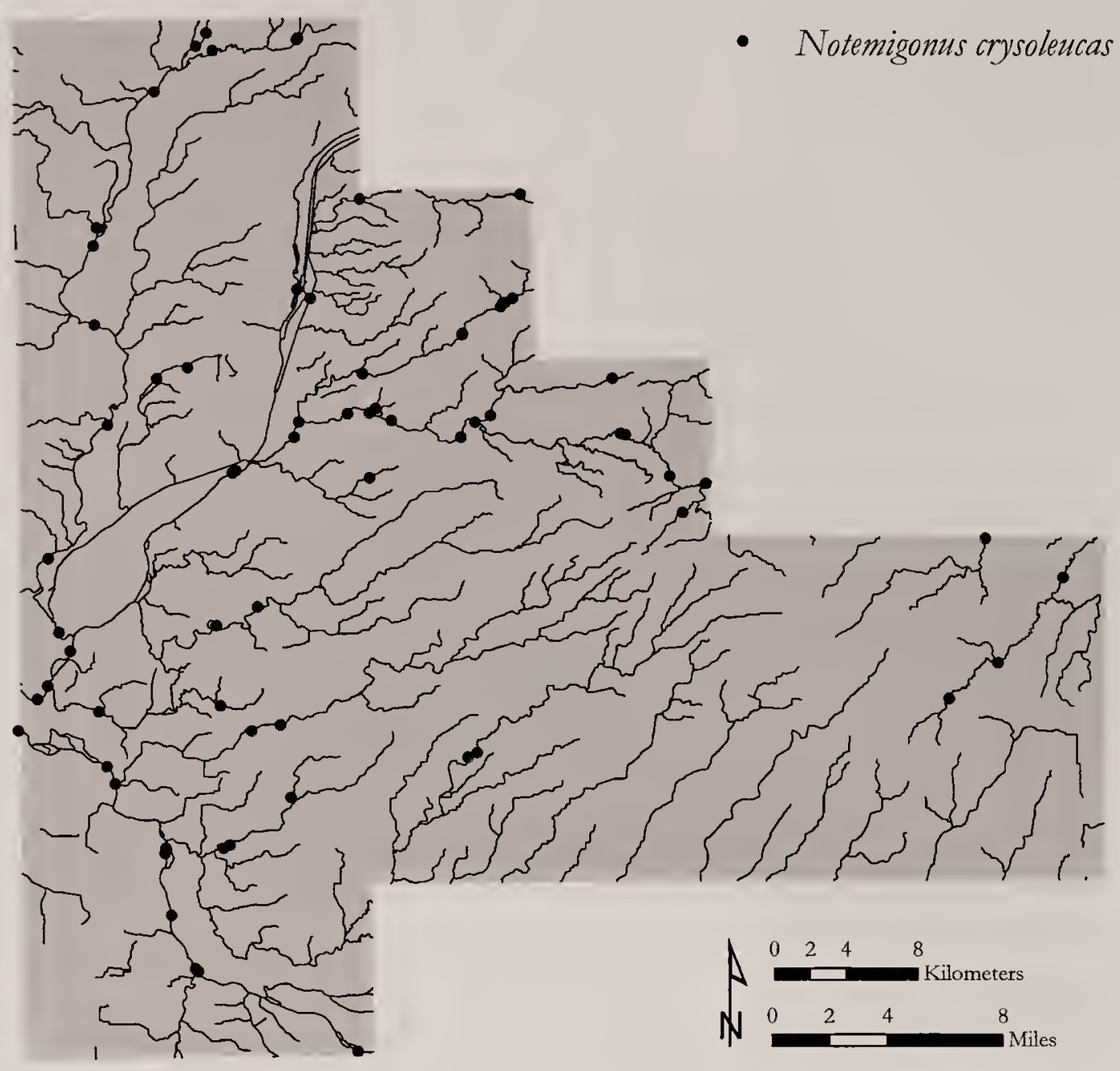

FIG. 35. Distribution of Notemigonus crysoleucas (Golden Shiner) in Will County, Illinois.

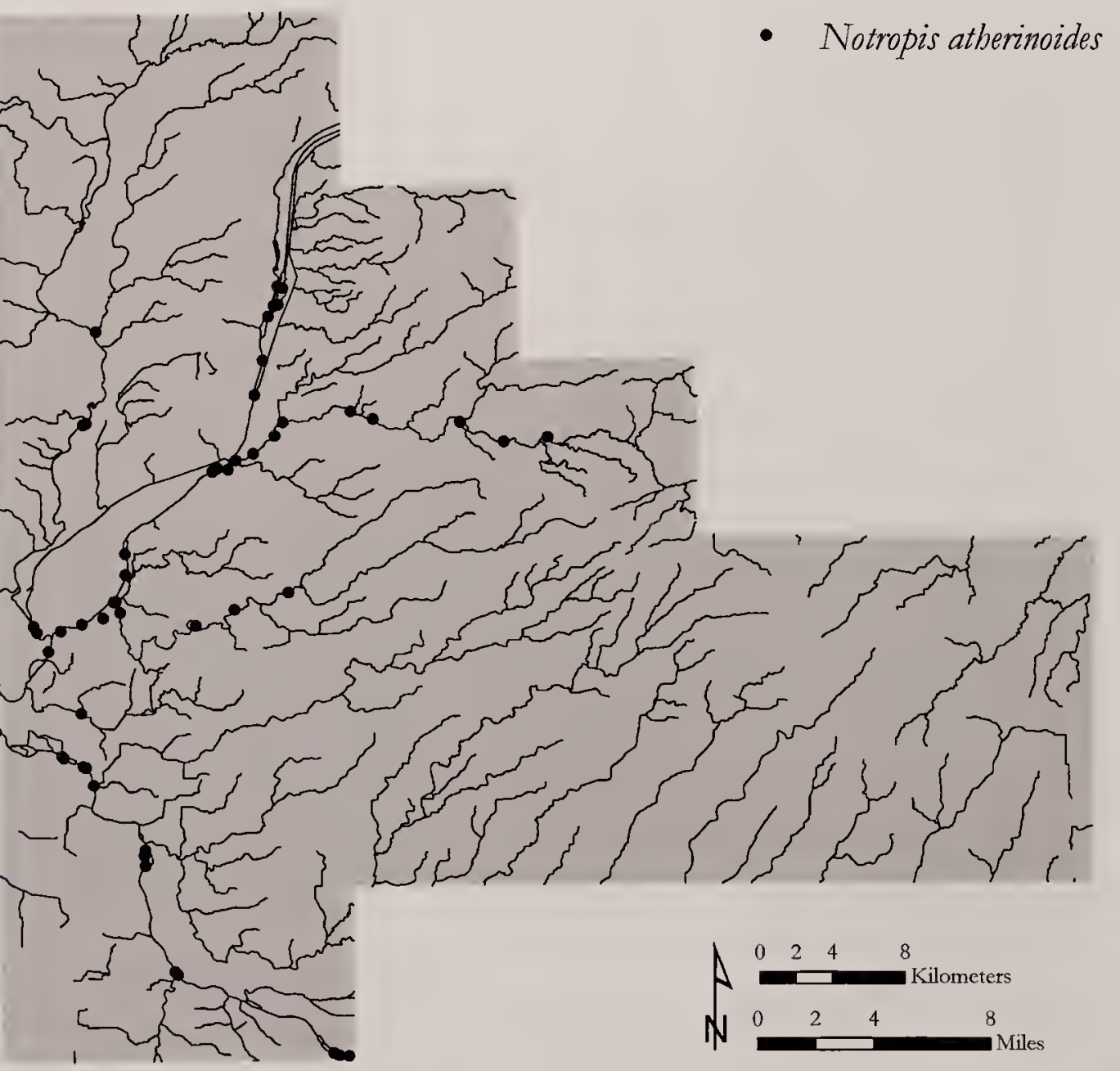

FIG. 36. Distribution of Notropis atherinoides (Emerald Shiner) in Will County, Illinois. 


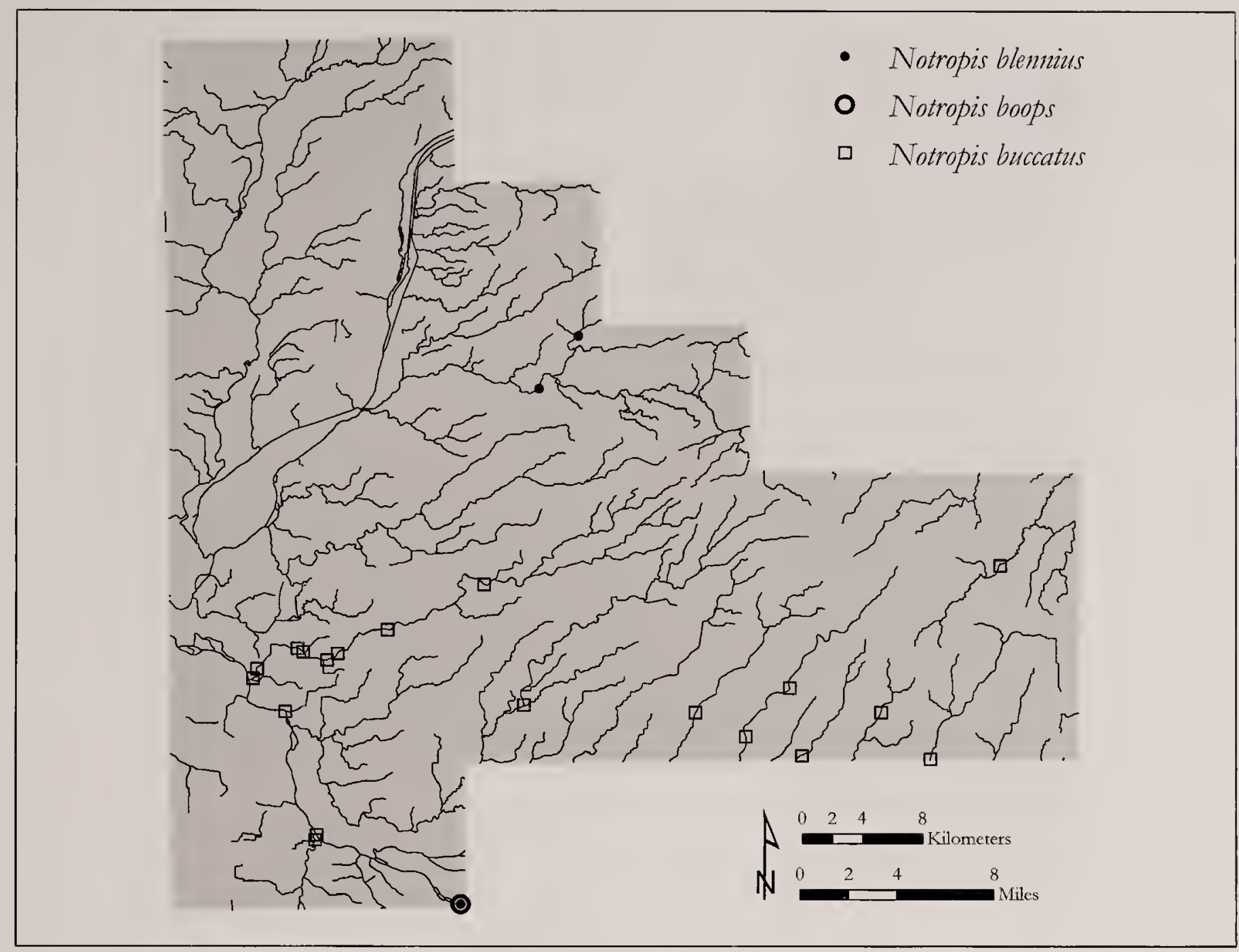

FIG. 37. Distribution of Notropis blennius (River Shiner), Notropis boops (Bigeye Shiner), and Notropis buccatus (Silverjaw Minnow) in Will County, Illinois.

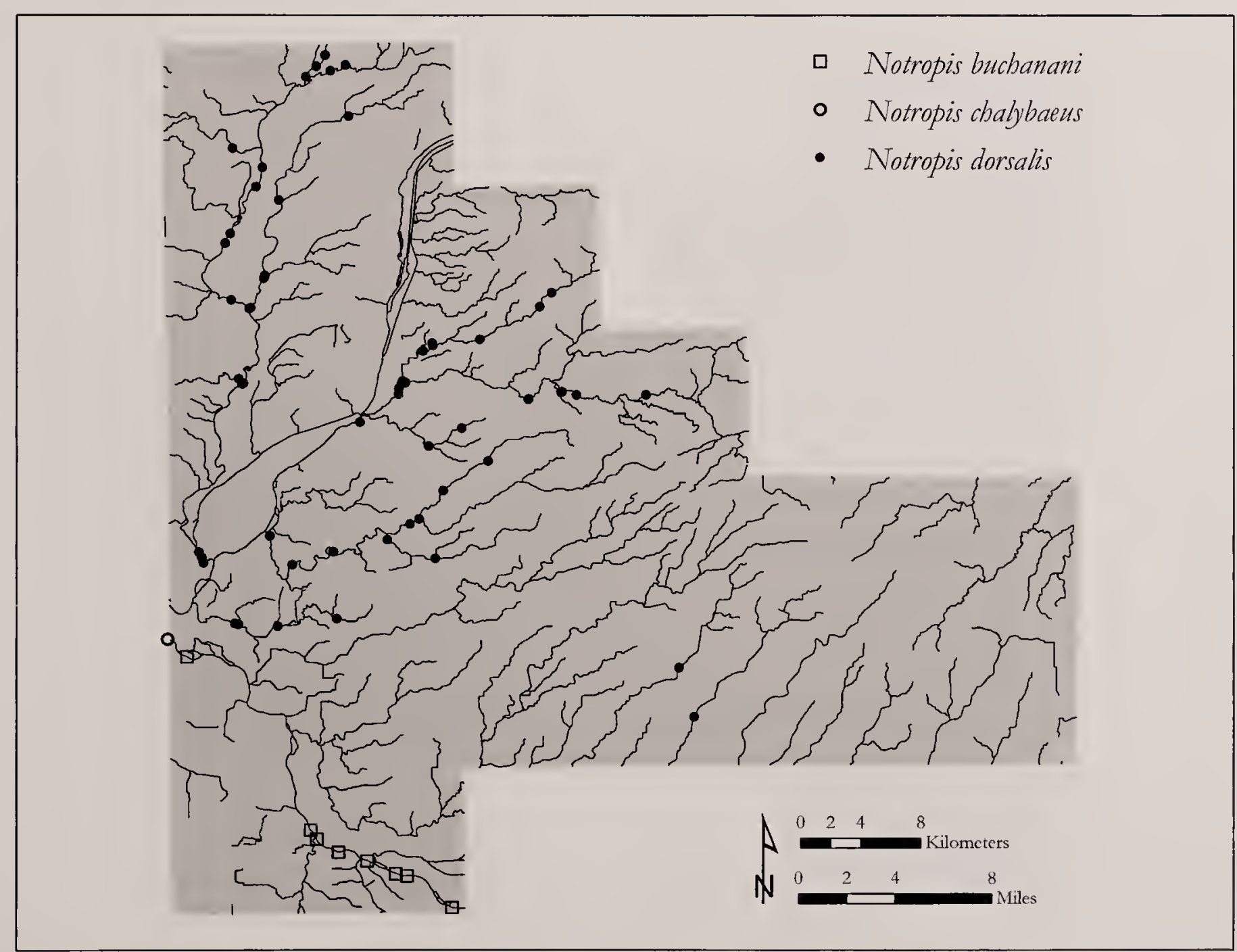

FIG. 38. Distribution of Notropis buchanani (Ghost Shiner), Notropis chalybaeus (Ironcolor Shiner), and Notropis dorsalis (Bigmouth Shiner) in Will County, Illinois. 


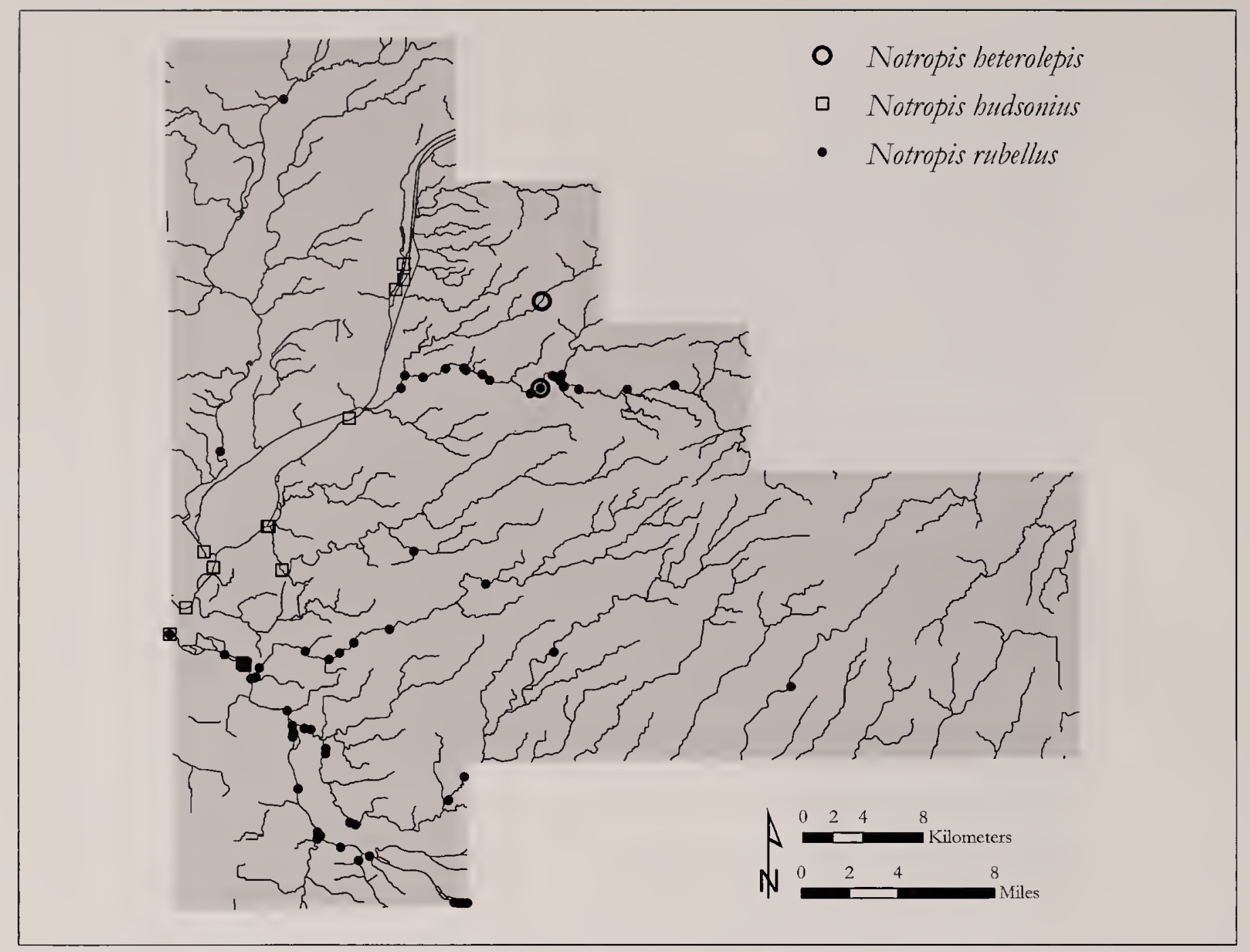

FiG. 39. Distribution of Notropis leterolepis (Blacknose Shiner), Notropis hudsonius (Spottail Shiner), and Notropis rubellus (Rosyface Shiner) in Will County, Illinois.

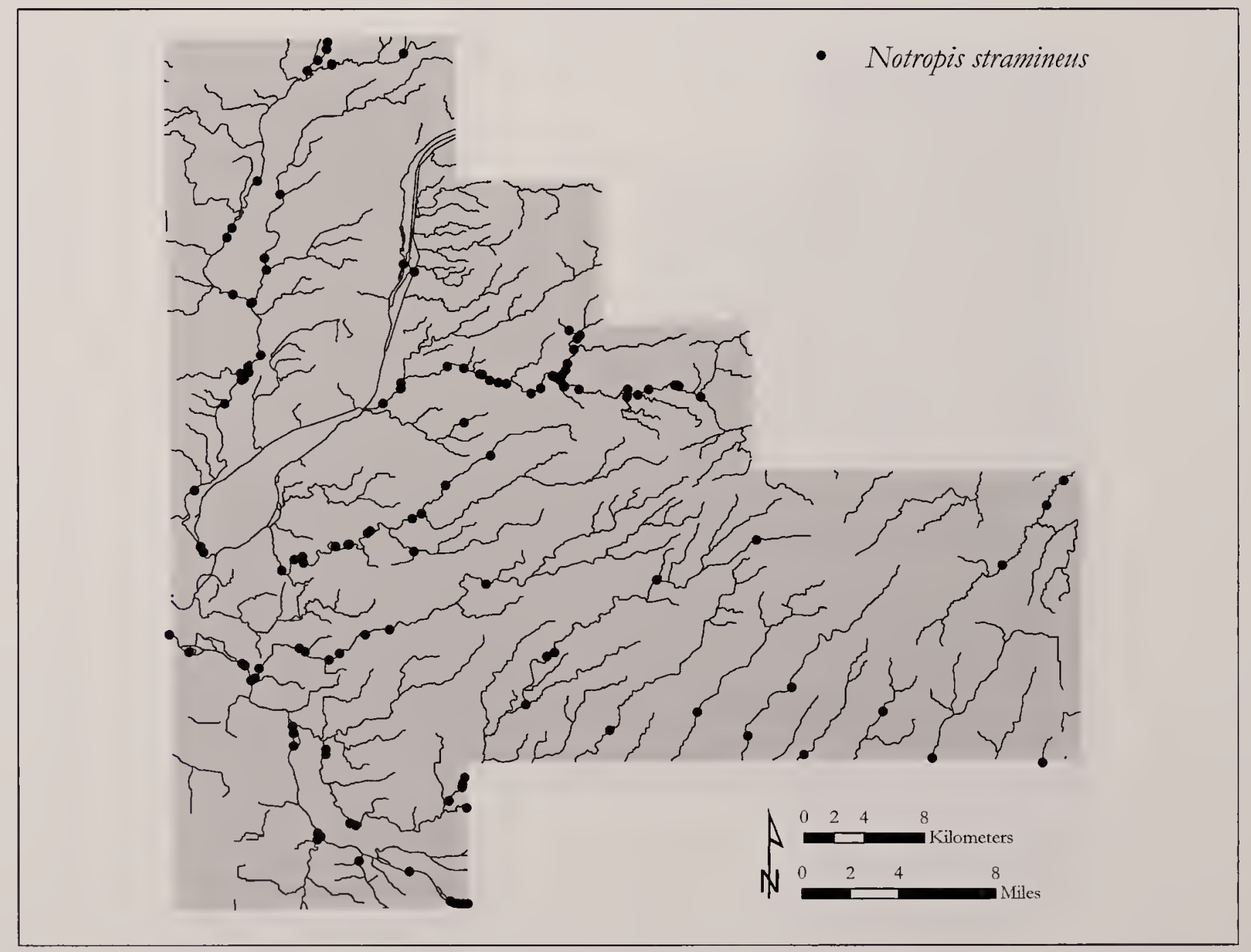

FiG. 40. Distribution of Notropis stramineus (Sand Shiner) in Will County, Illinois. 


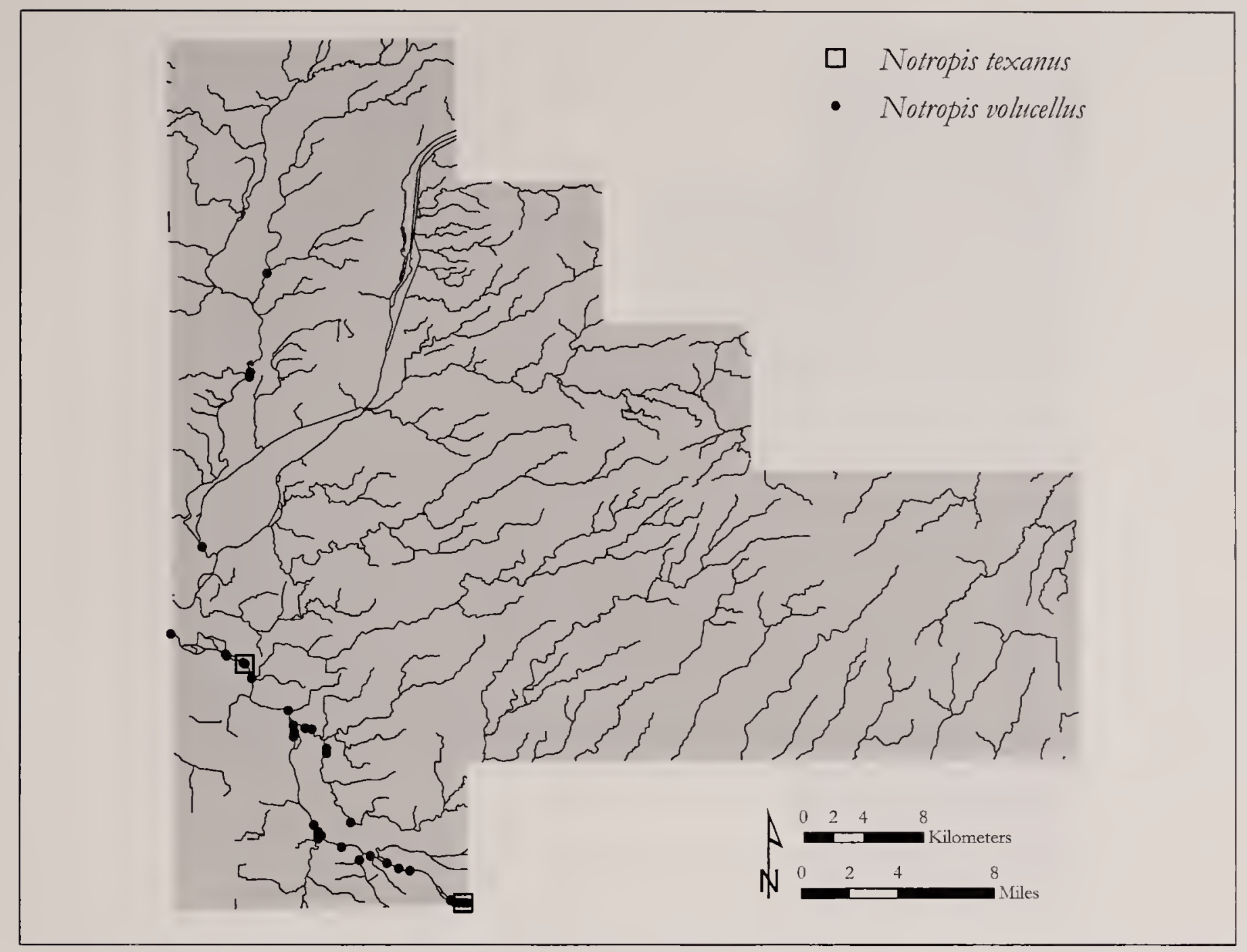

FIG. 41. Distribution of Notropis texanus (Weed Shiner) and Notropis volucellus (Mimic Shiner) in Will County, Illinois.

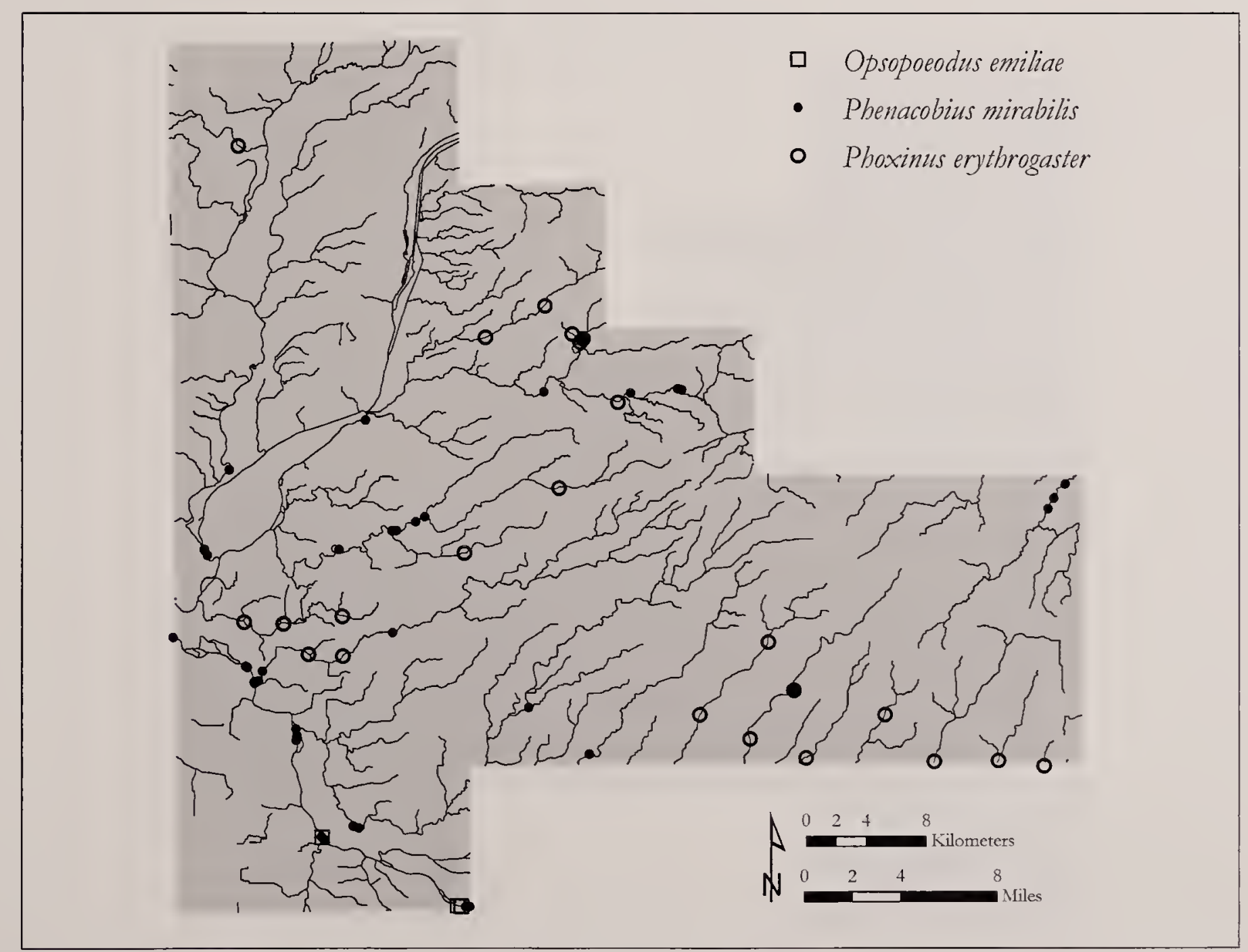

FIg. 42. Distribution of Opsopoeodus emiliae (Pugnose Minnow), Phenacobius mirabilis (Suckermouth Minnow), and Phoxinus erytlirogaster (Southern Redbelly Dace) in Will County, Illinois. 


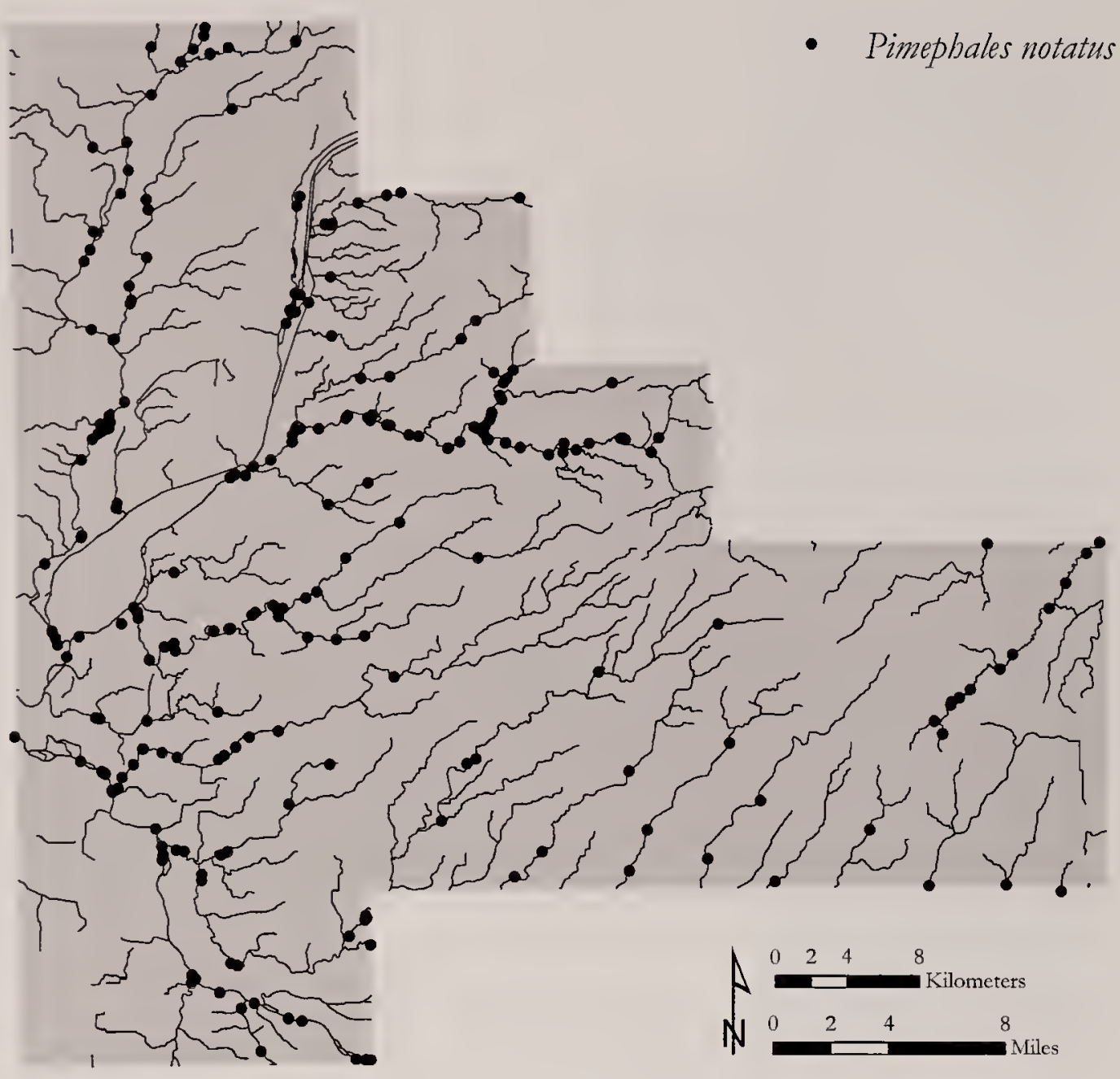

Fig. 43. Distribution of Pimephales notatus (Bluntnose Minnow) in Will County, Illinois.

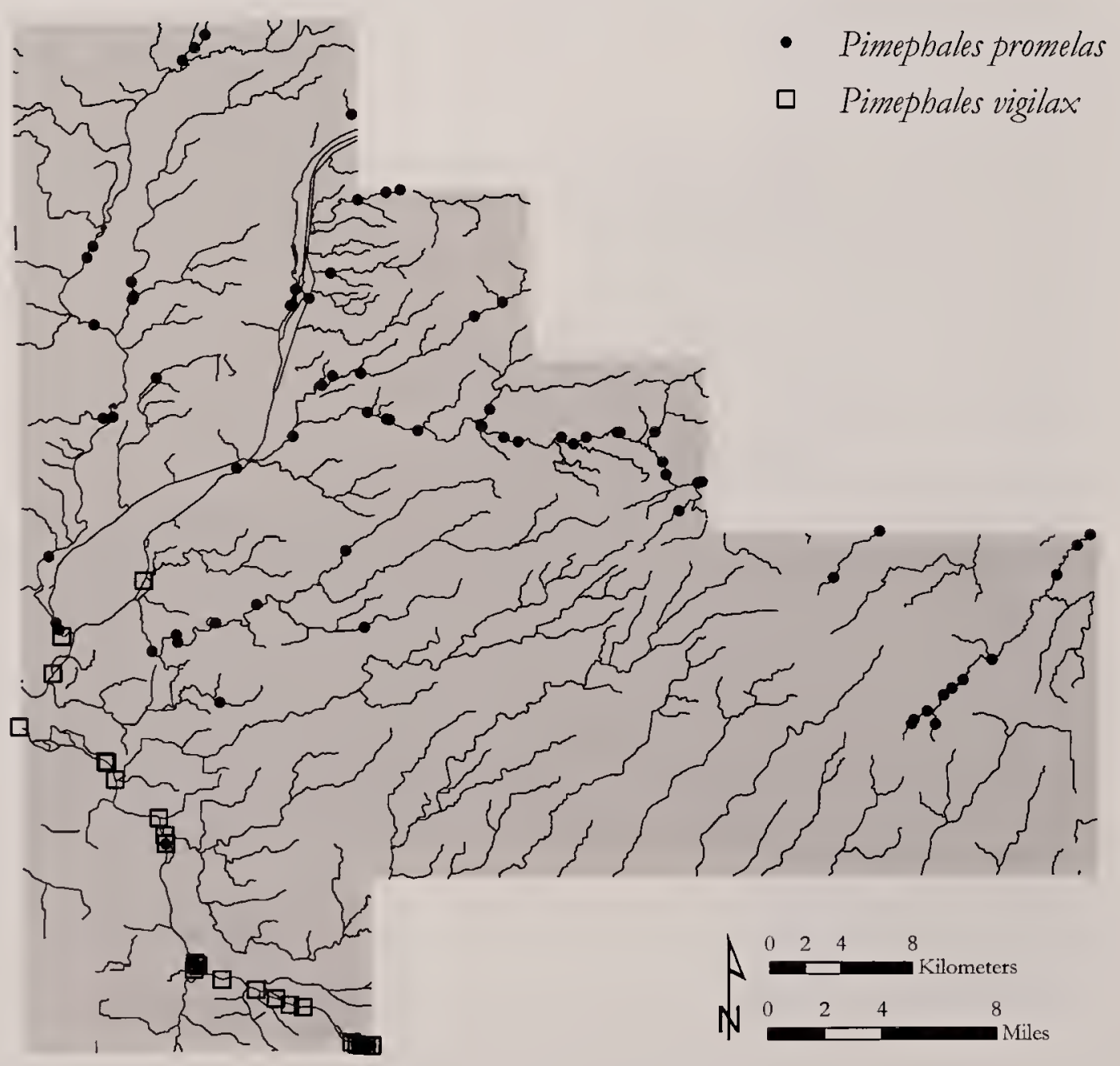

FIG. 44. Distribution of Pimephales promelas (Fathead Minnow) and Pimephales vigilax (Bullhead Minnow) in Will County, Illinois. 


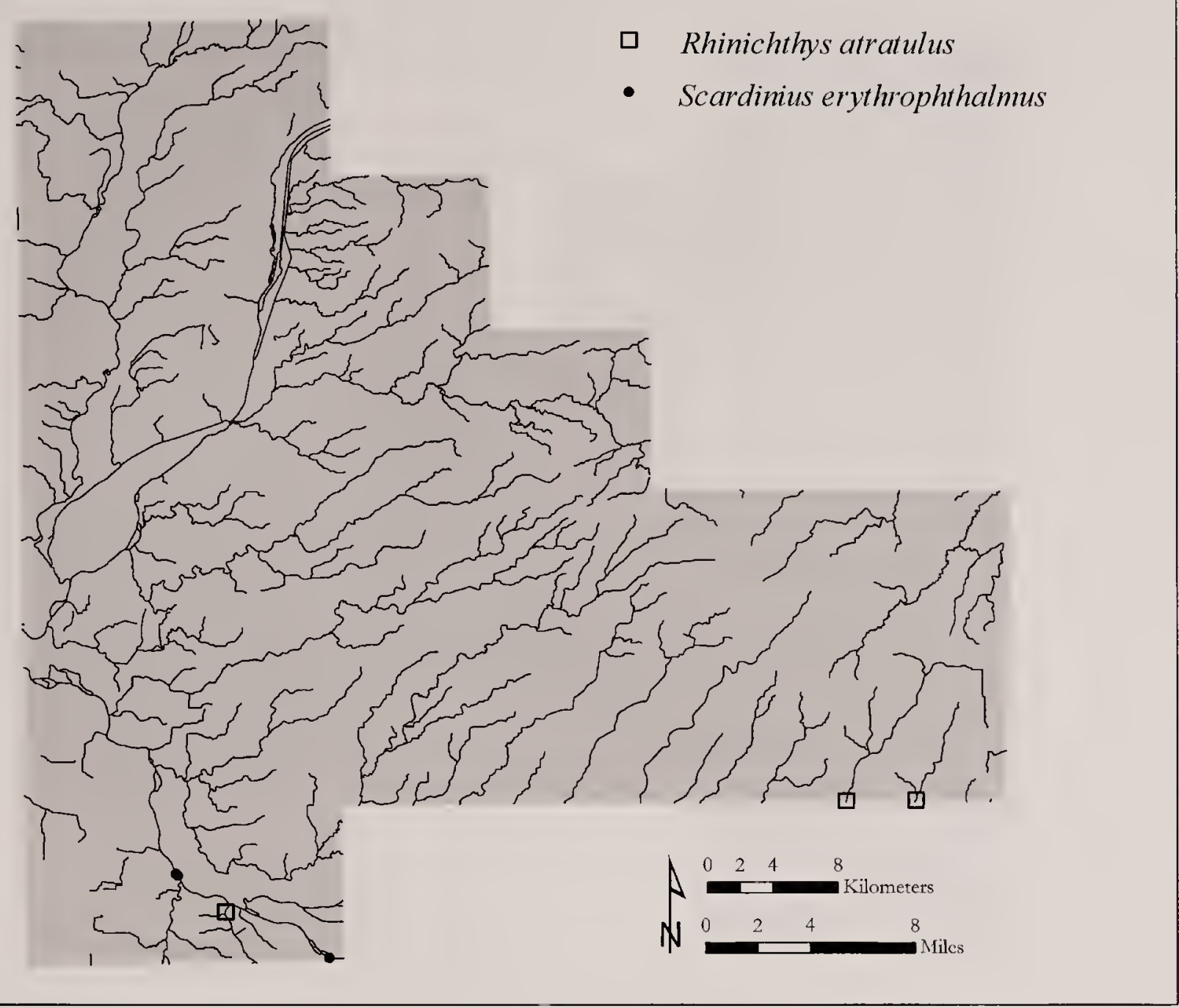

FIG. 45. Distribution of Rhinichthys atratulus (Blacknose Dace) and Scardinius erythrophthalnius (Rudd) in Will County, Illinois.

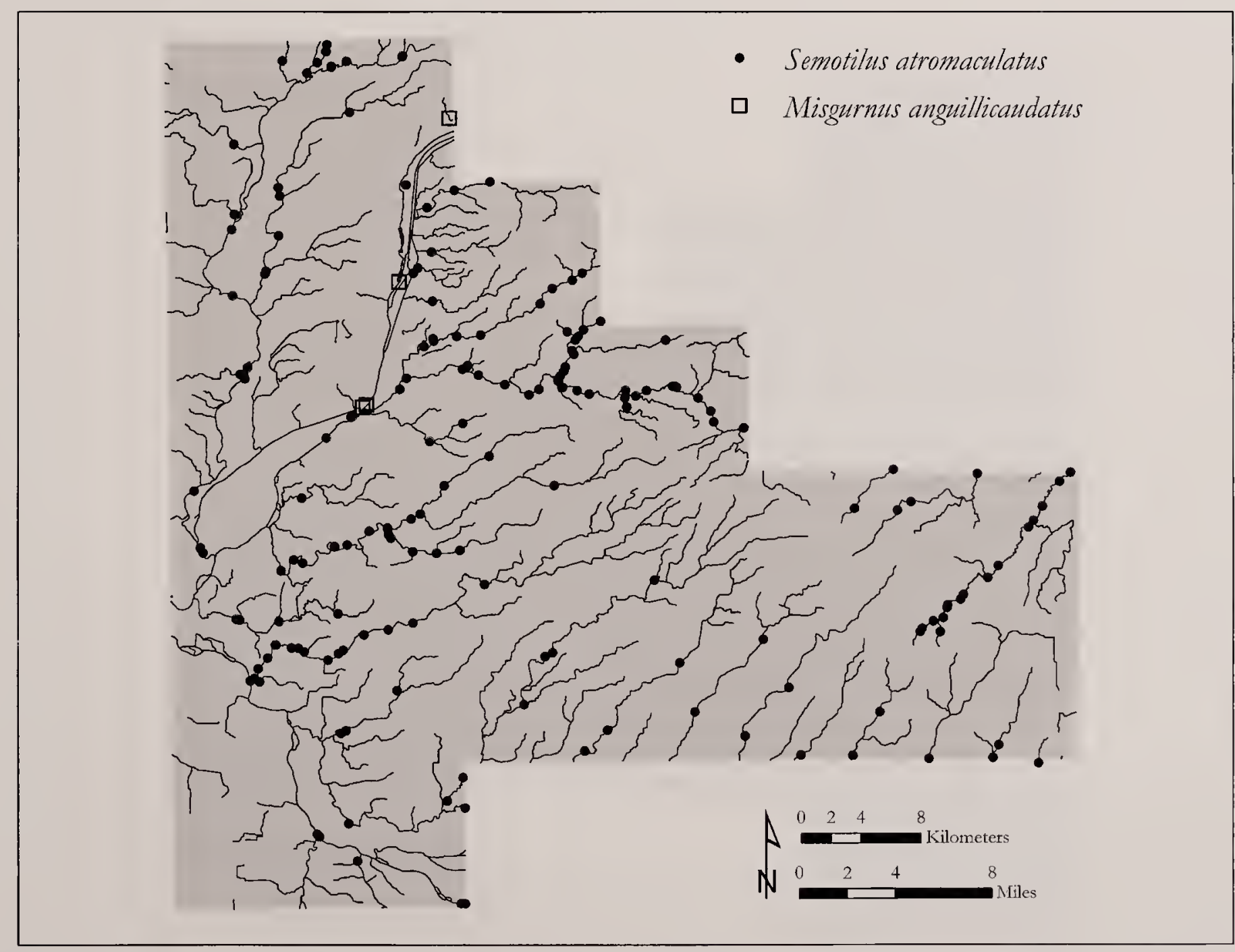

FIG. 46. Distribution of Sellotilus atrollaculatus (Creek Chub) and Misgurmus allguillicaudatus (Oriental Weatherfish) in Will County, Illinois. 


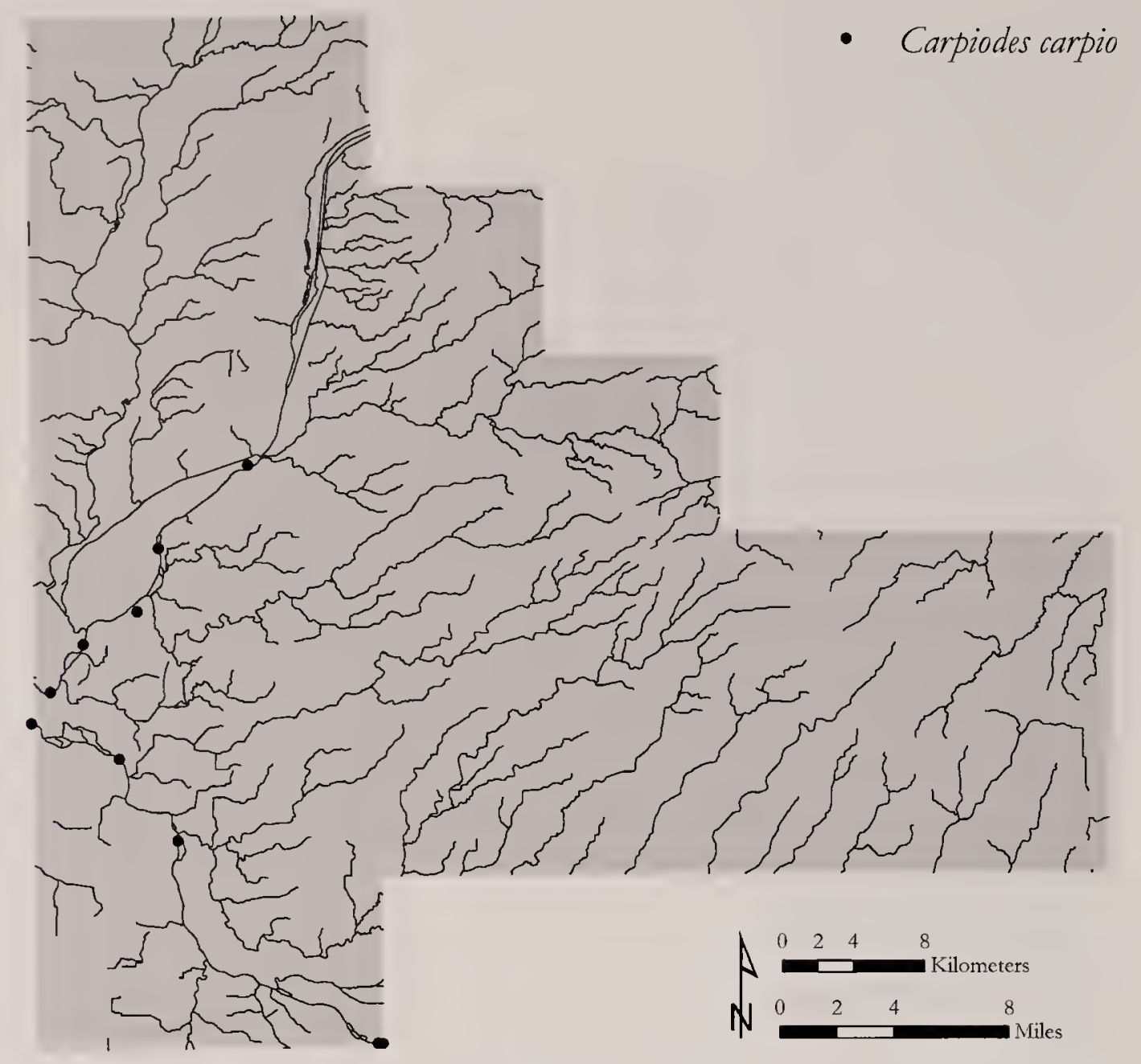

F1G. 47. Distribution of Carpiodes carpio (River Carpsucker) in Will County, Illinois.

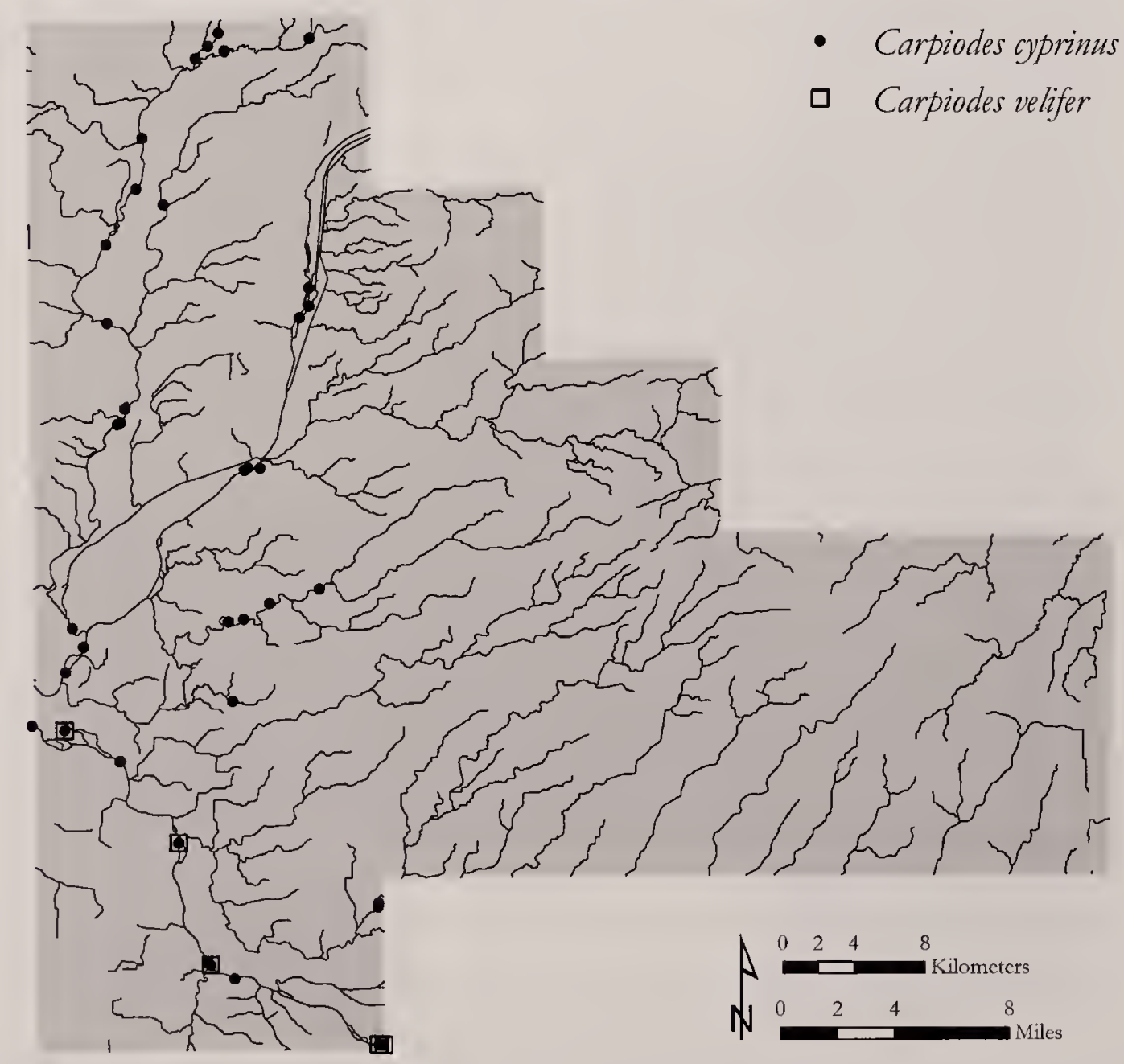

FIG. 48. Distribution of Carpiodes cyprinus (Quillback) and Carpiodes velifer (Highfin Carpsucker) in Will County, Illinois. 


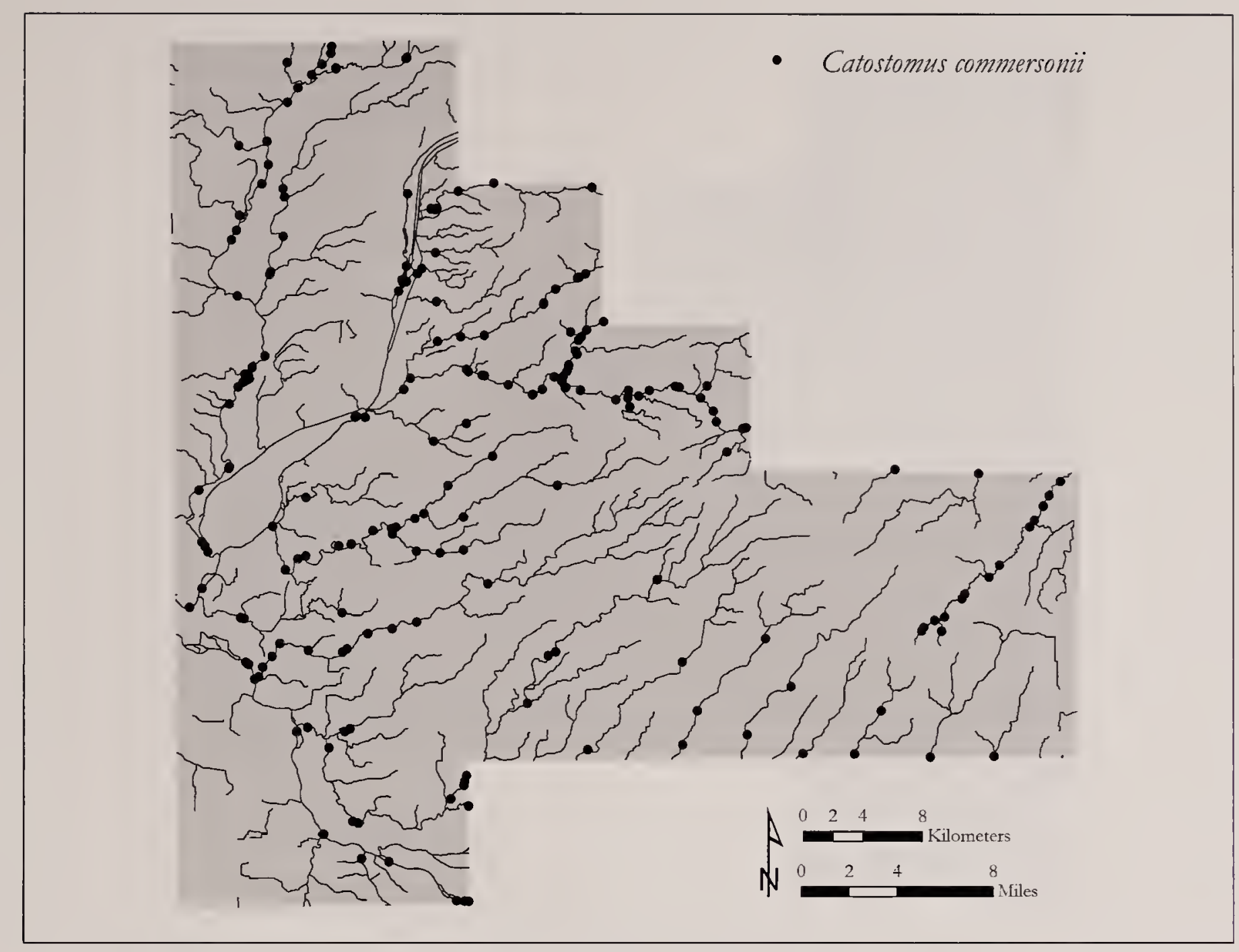

FIG. 49. Distribution of Catostomus commersonii (White Sucker) in Will County, Illinois.

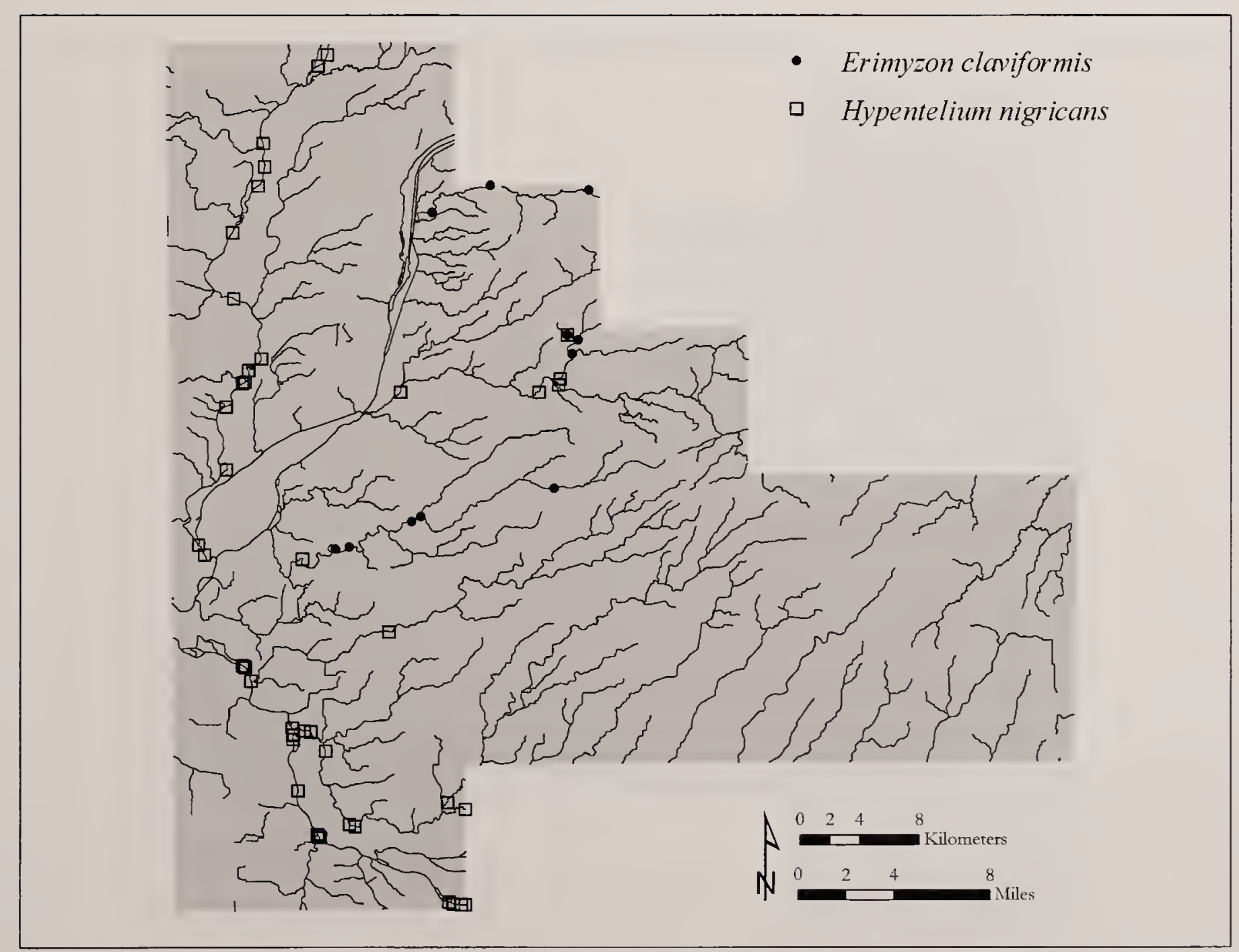

FIG. 50. Distribution of Erimyzon claviformis (Western Creek Chubsucker) and Hypentelium nigricans (Northern Hog Sucker) in Will County, Illinois. 


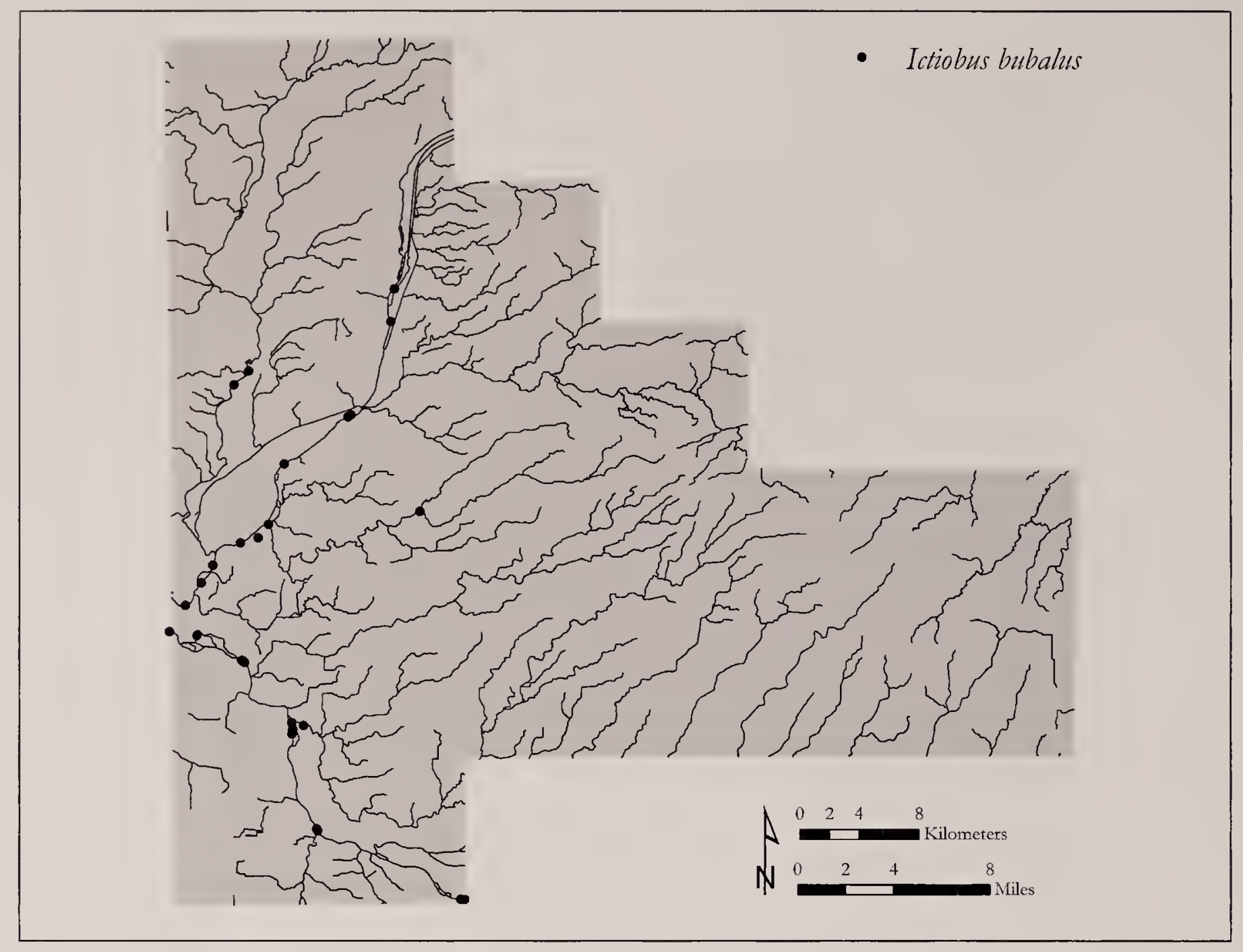

FIG. 51. Distribution of Ictiobus bubalus (Smallmouth Buffalo) in Will County, Illinois.

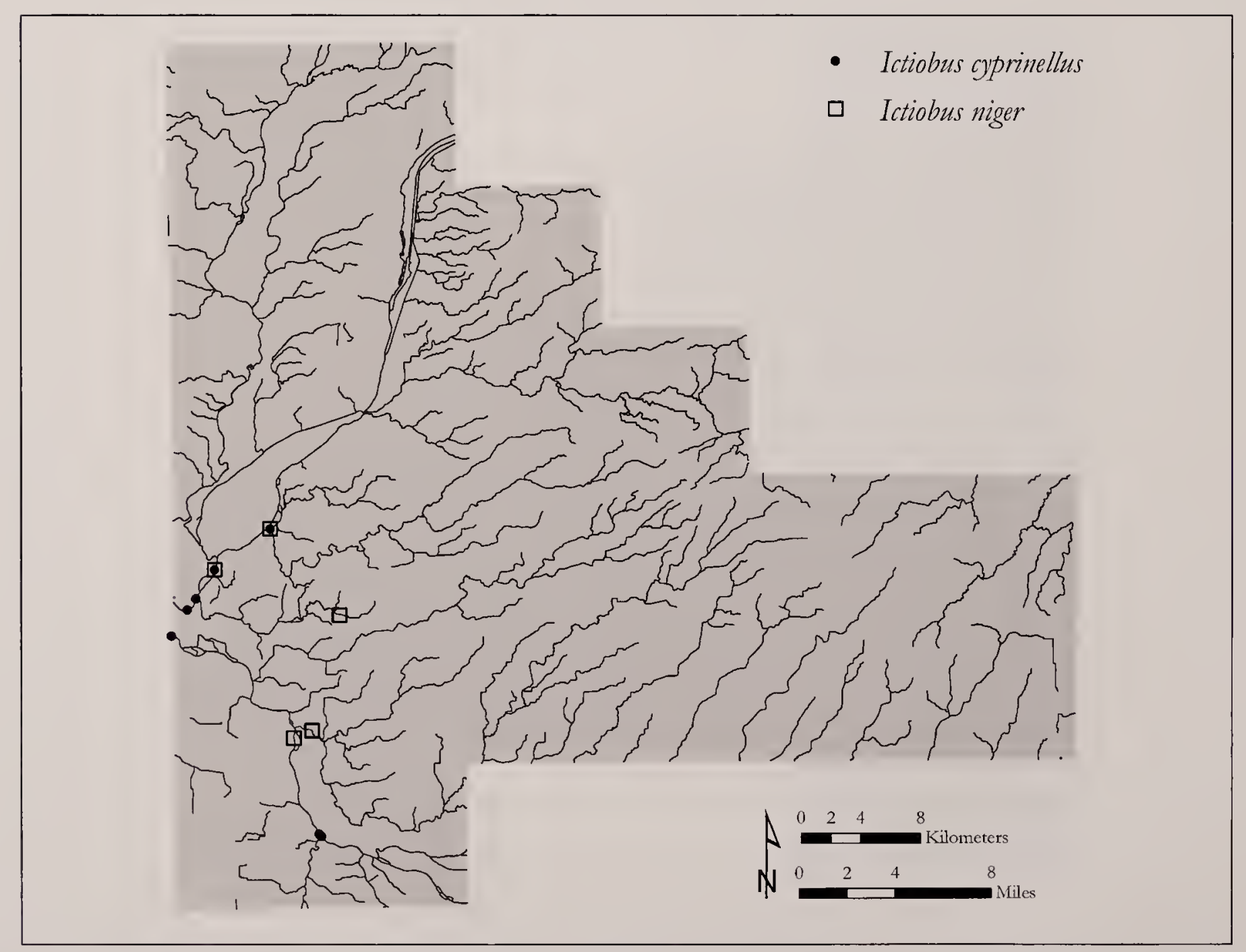

FIG. 52. Distribution of Ictiobus cyprinellus (Bigmouth Buffalo) and Ictiobus niger (Black Buffalo) in Will County, Illinois. 


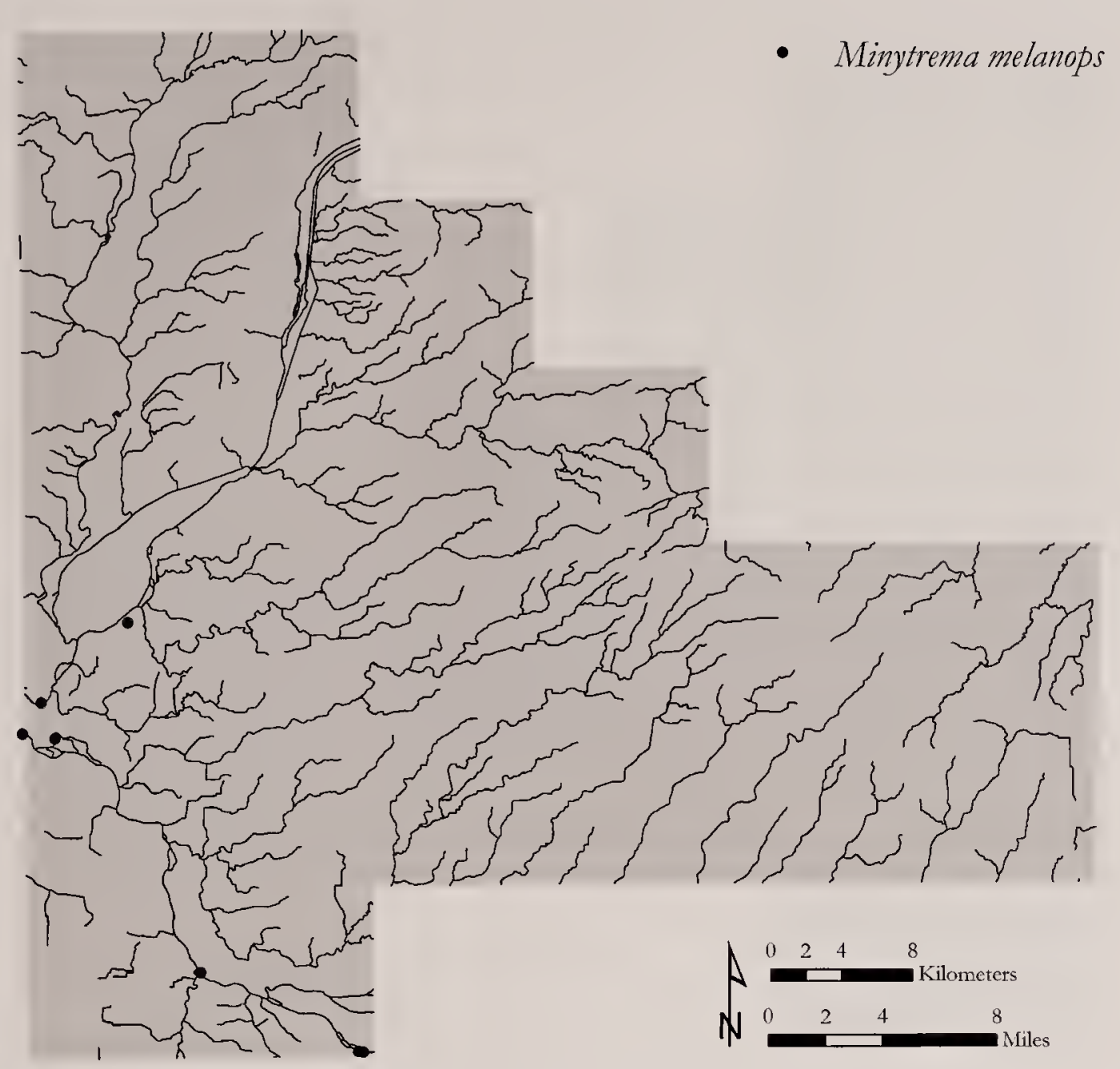

Fig. 53. Distribution of Minytrema melanops (Spotted Sucker) in Will County, Illinois.

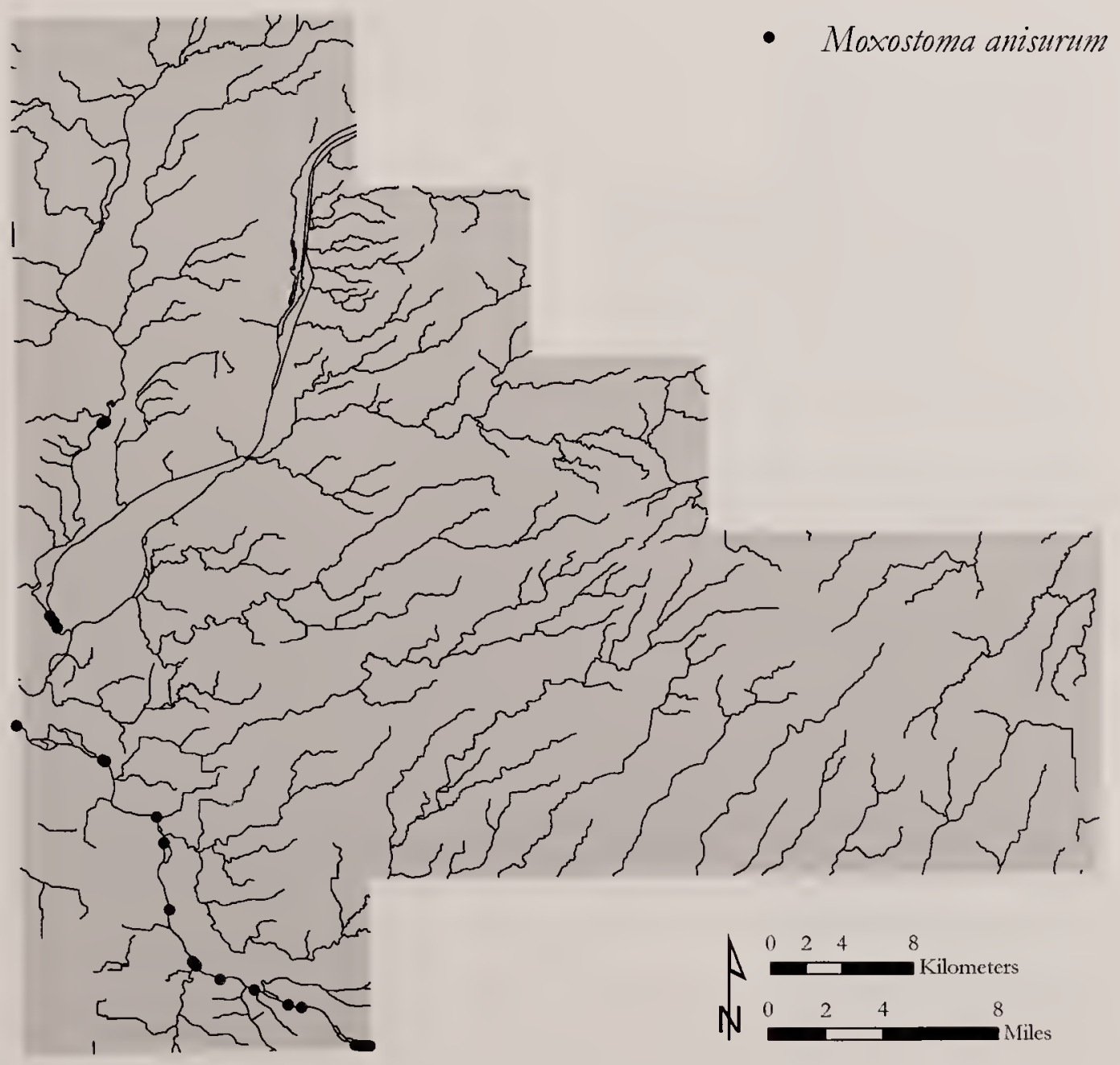

Fig. 54. Distribution of Moxostoma anisurum (Silver Redhorse) in Will County, Illinois. 


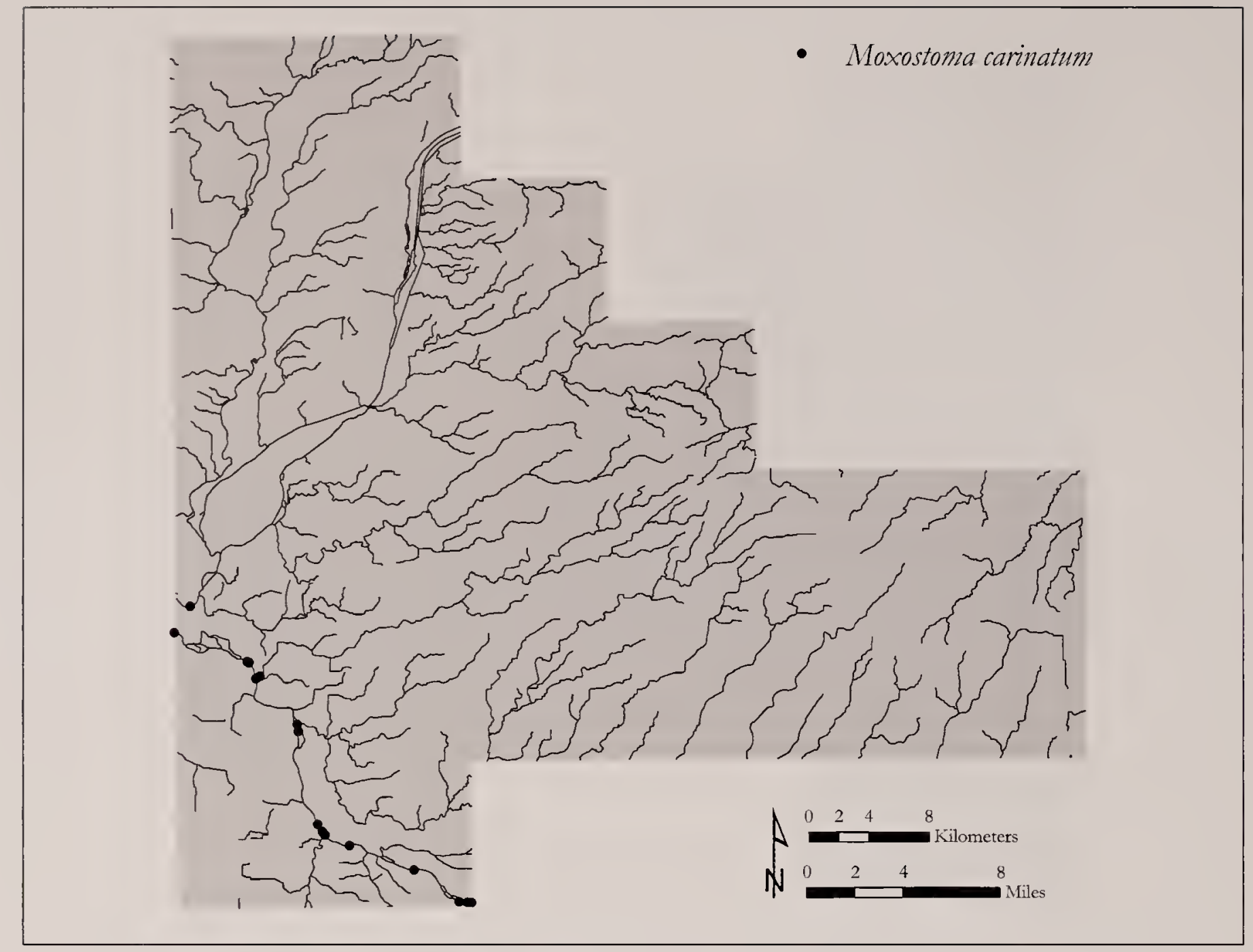

FIG. 55. Distribution of Moxostoma carinatum (River Redhorse) in Will County, Illinois.

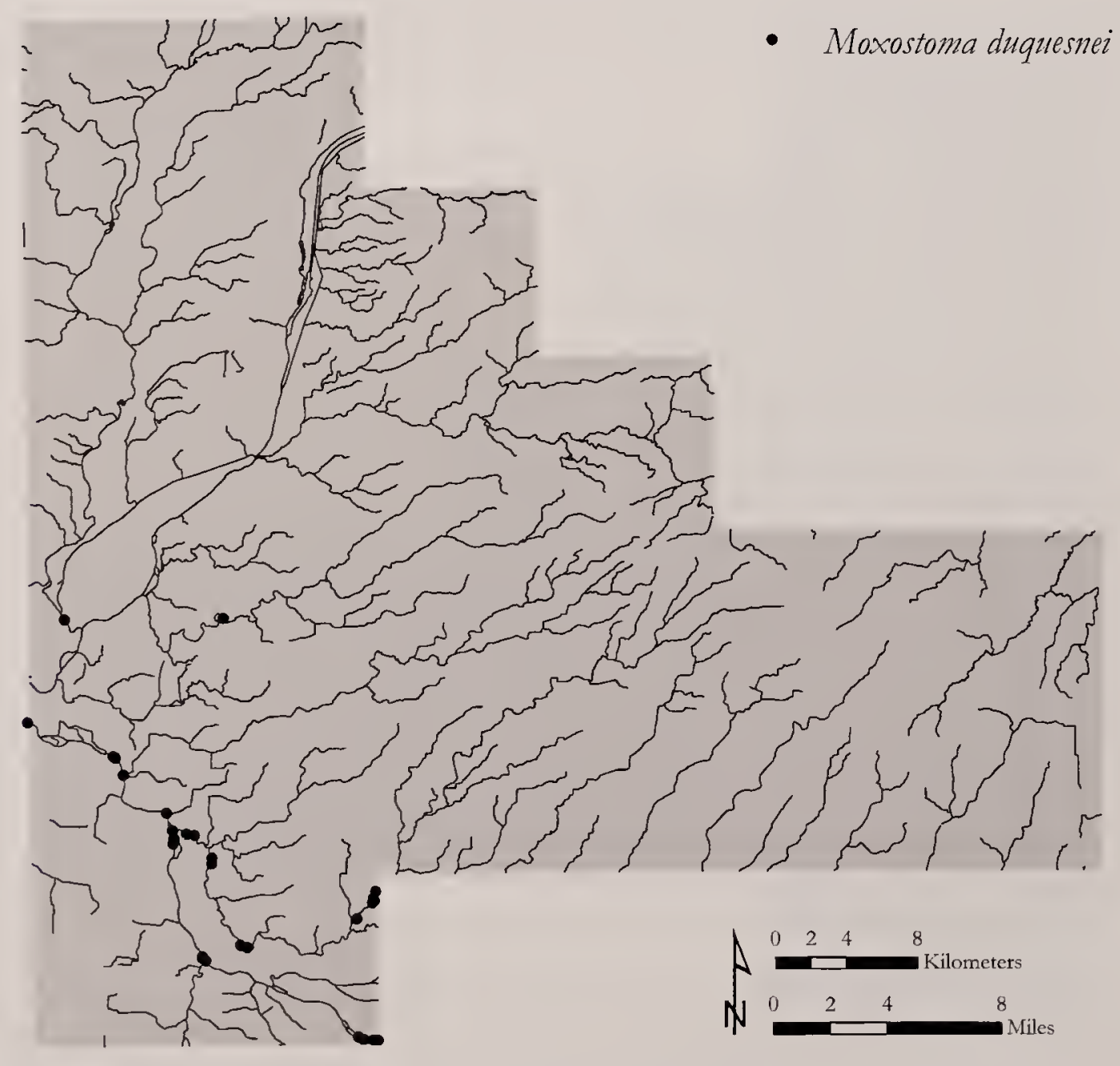

FIG. 56. Distribution of Moxostoma duquesnei (Black Redhorse) in Will County, Illinois. 


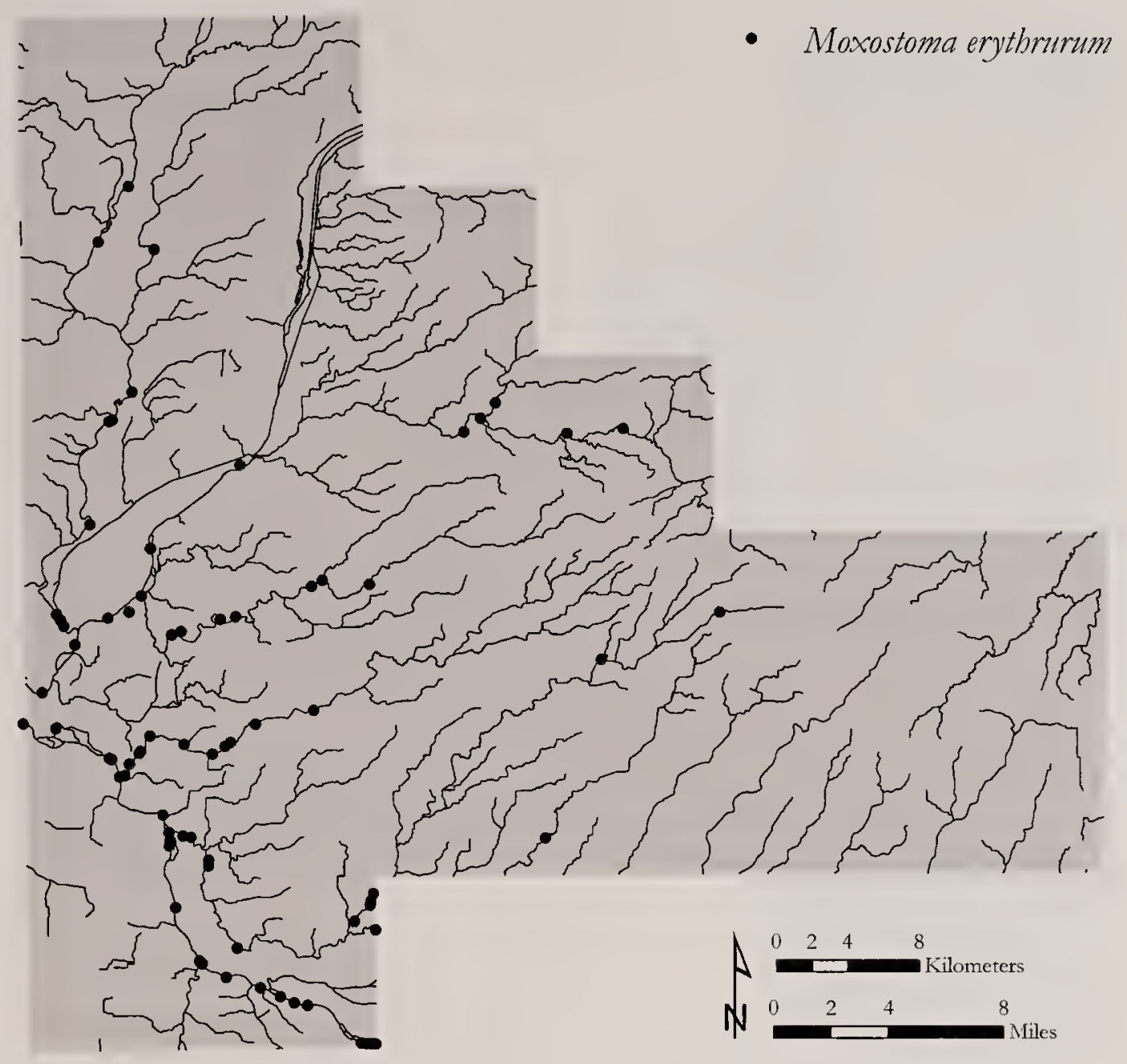

FIG. 57. Distribution of Moxostoma erythrurum (Golden Redhorse) in Will County, Illinois.

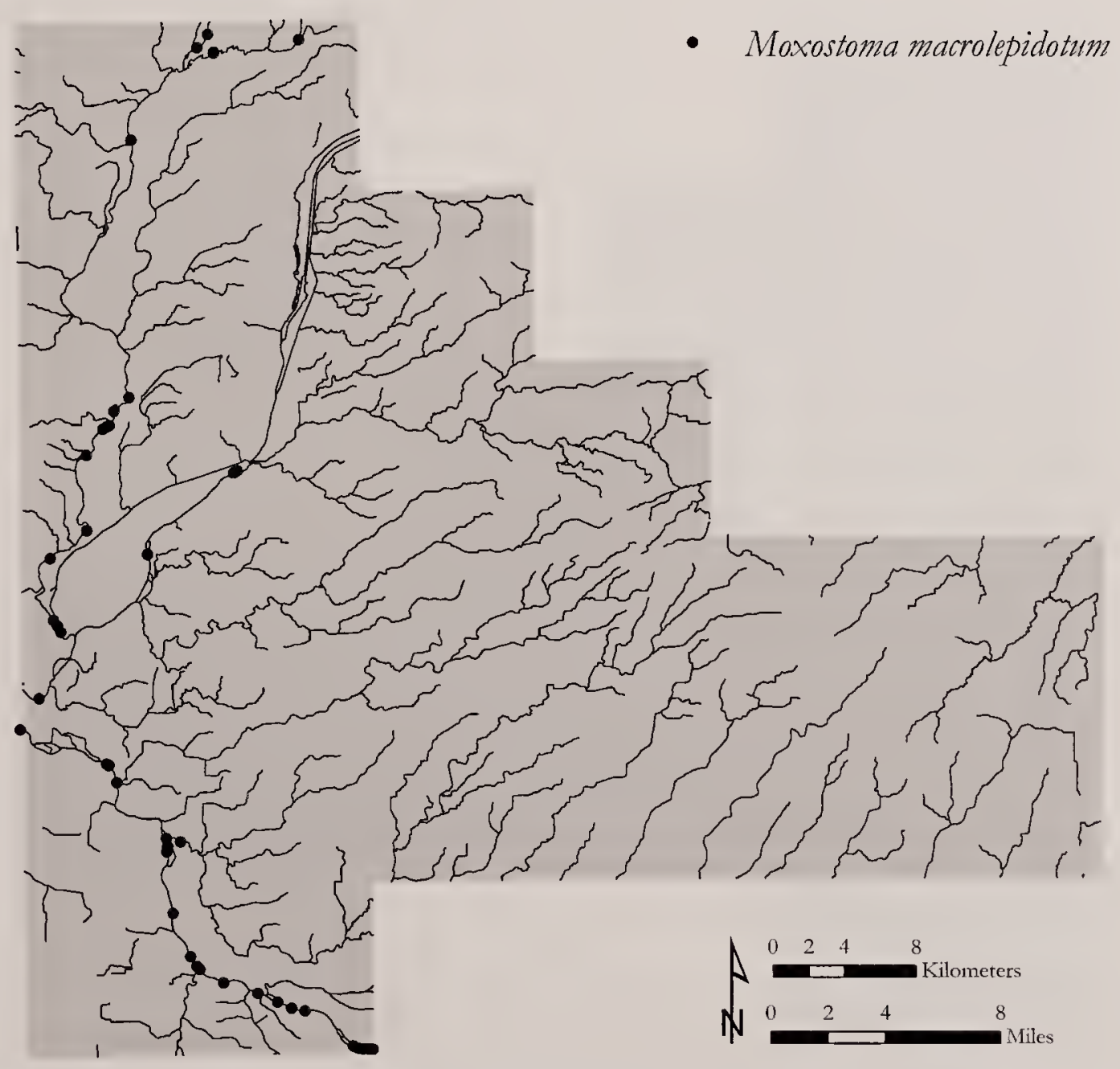

Fig. 58. Distribution of Moxostoma macrolepidotum (Shorthead Redhorse) in Will County, Illinois. 


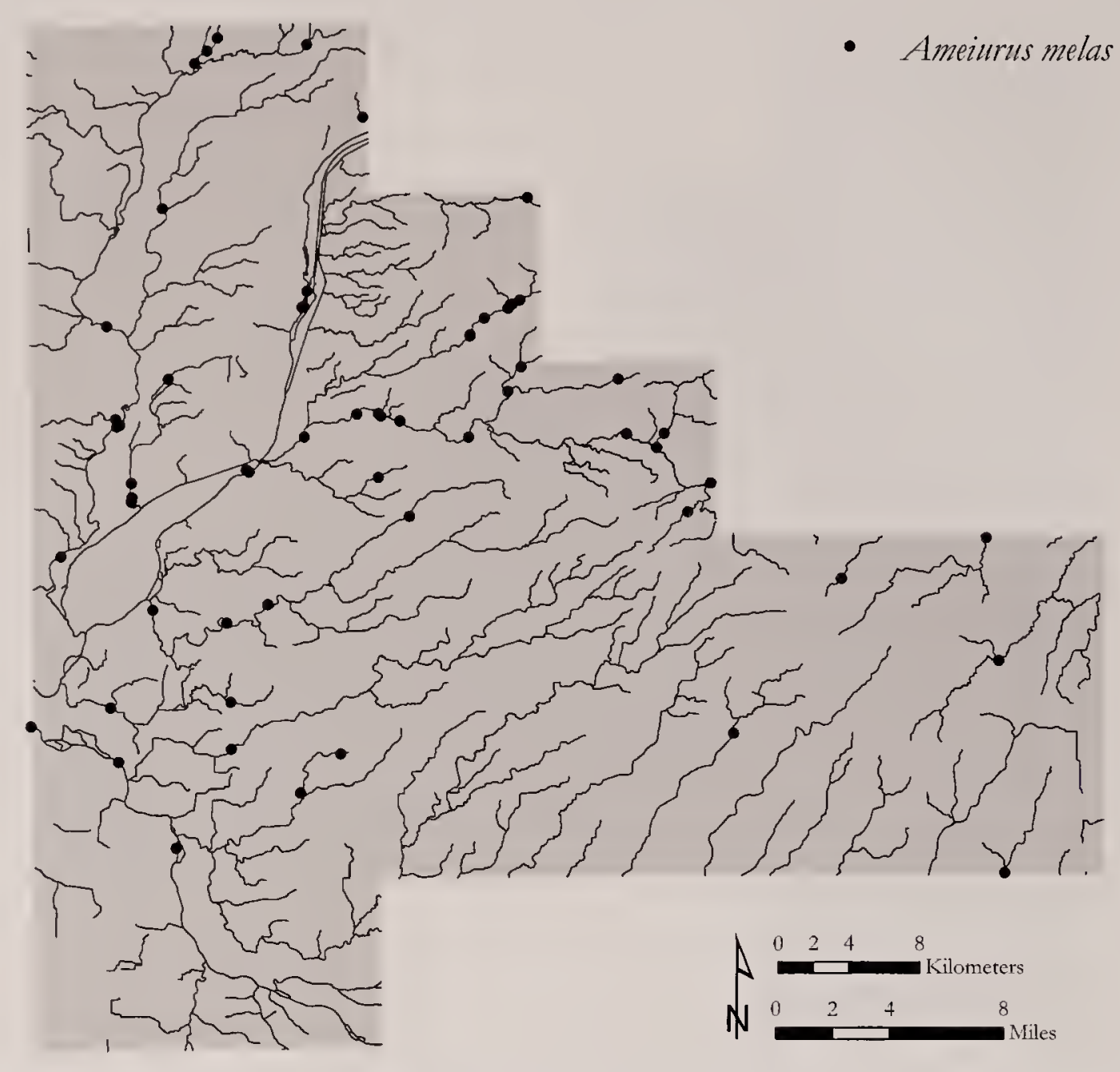

FIG. 59. Distribution of Ameinlus melas (Black Bullhead) in Will County, Illinois.

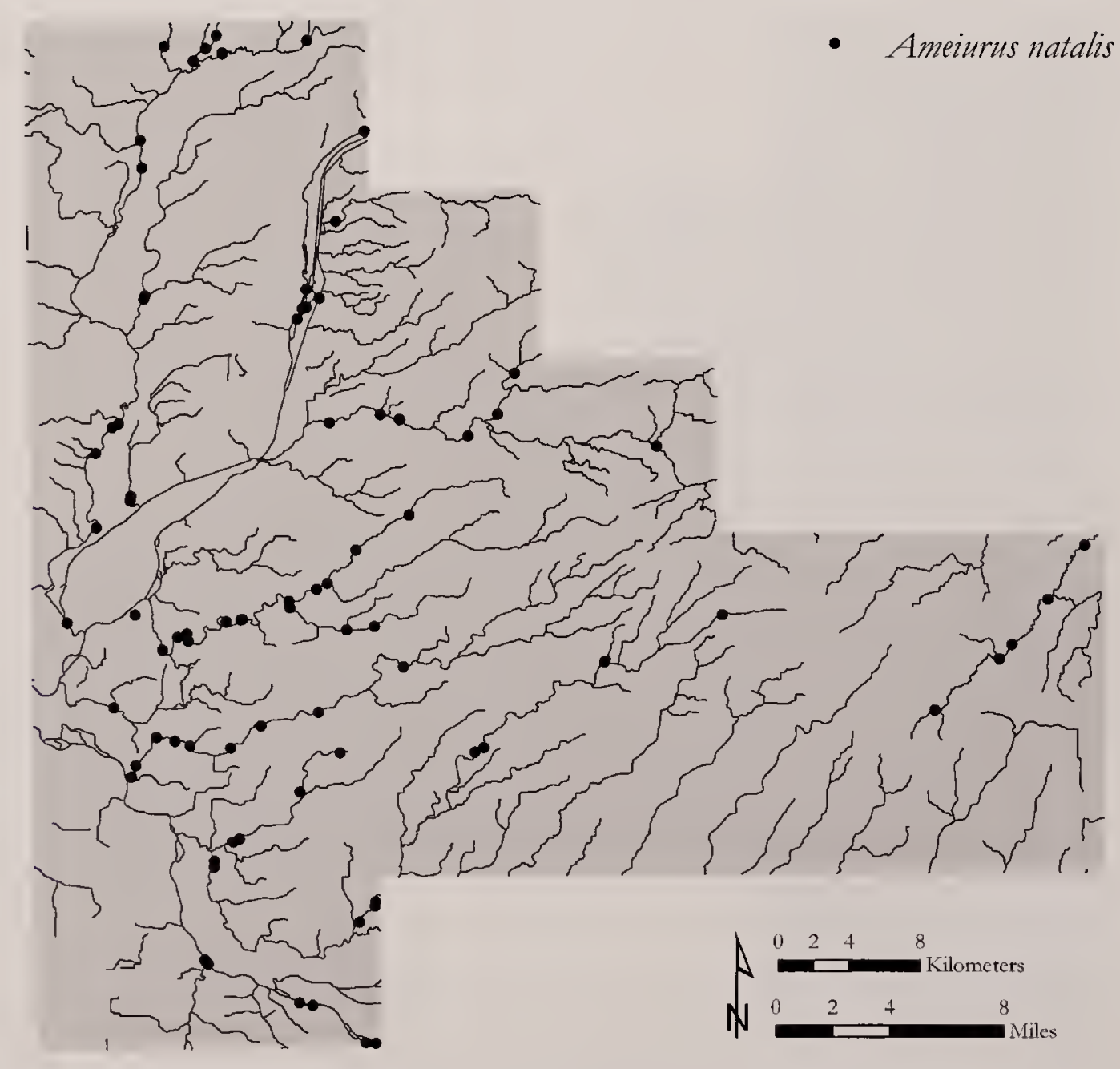

FIG. 60. Distribution of Ameiurus natalis (Yellow Bullhead) in Will County, Illinois. 


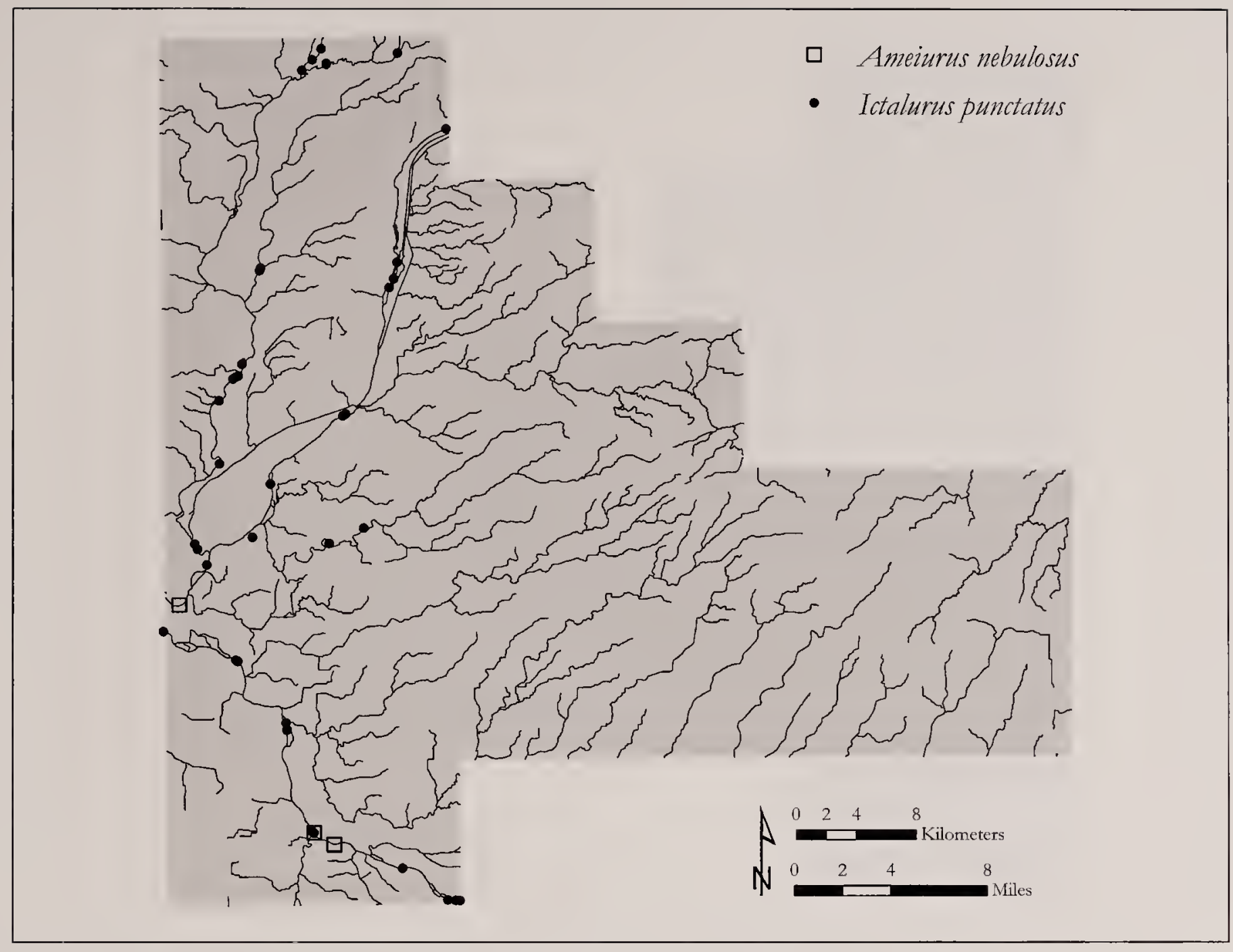

FIG. 61. Distribution of Ameiurus nebulosus (Brown Bullhead) and Ictalurus punctatus (Channel Catfish) in Will County, Illinois.

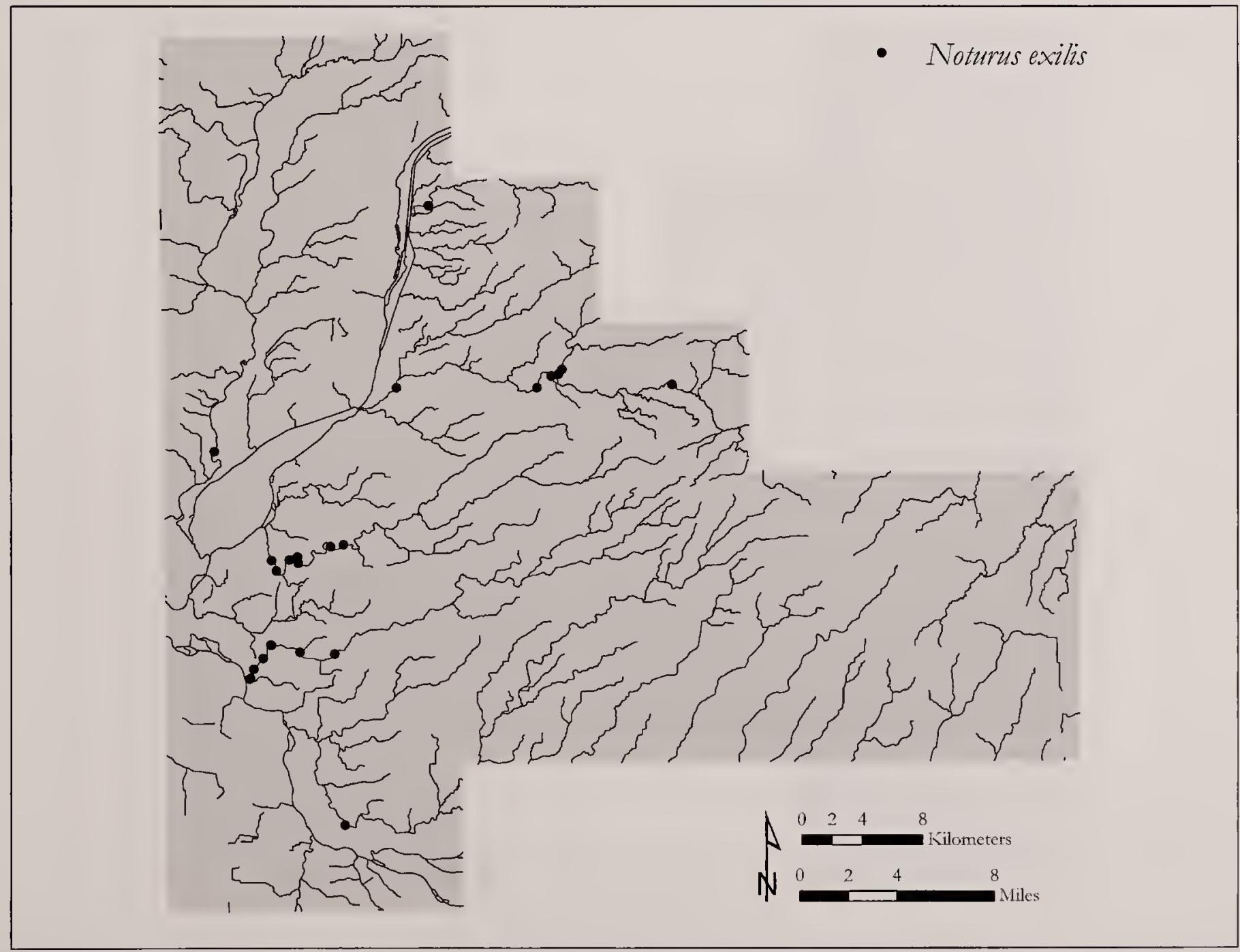

FIG. 62. Distribution of Noturus exilis (Slender Madtom) in Will County, Illinois. 


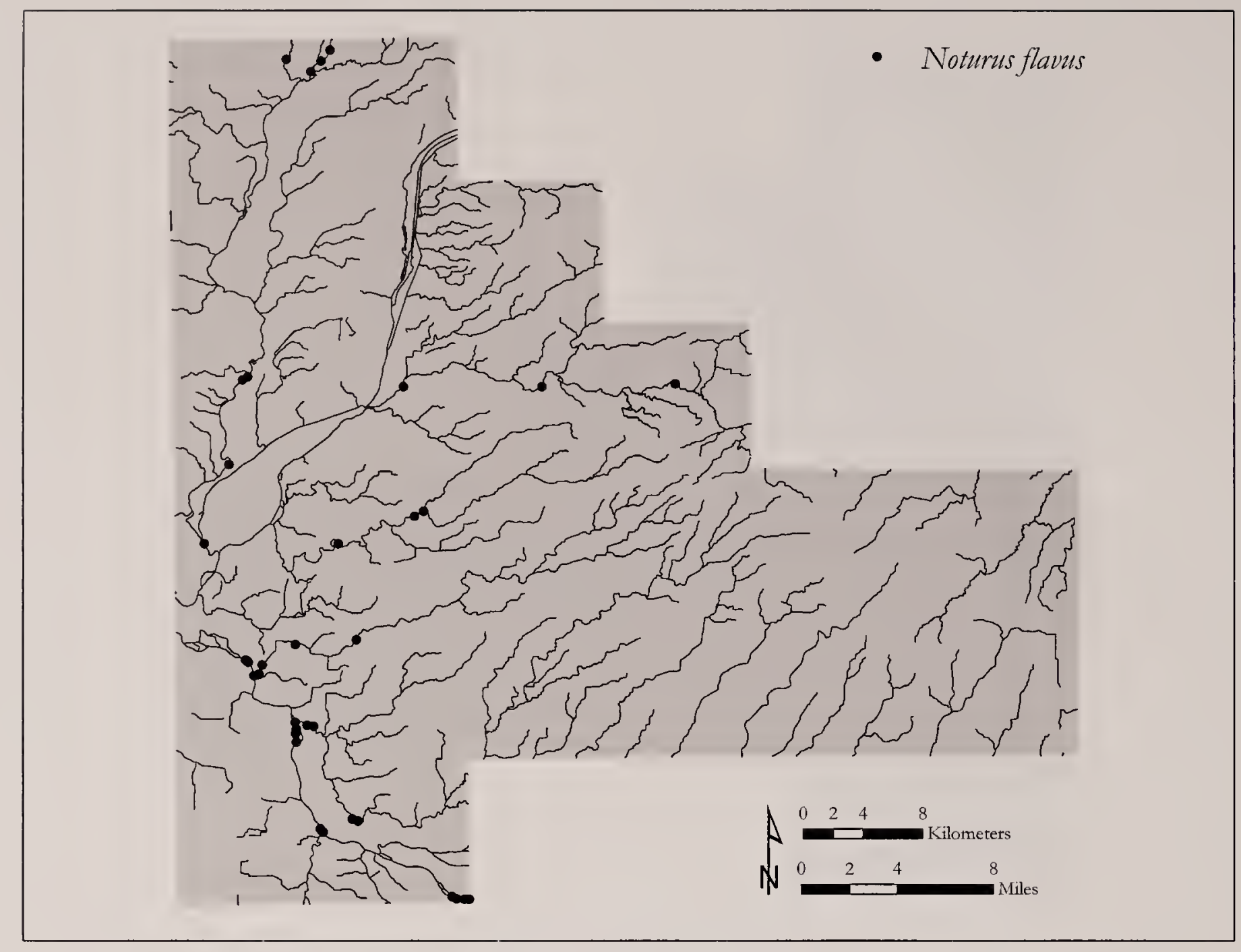

FIG. 63. Distribution of Noturus flavus (Stonecat) in Will County, Illinois.

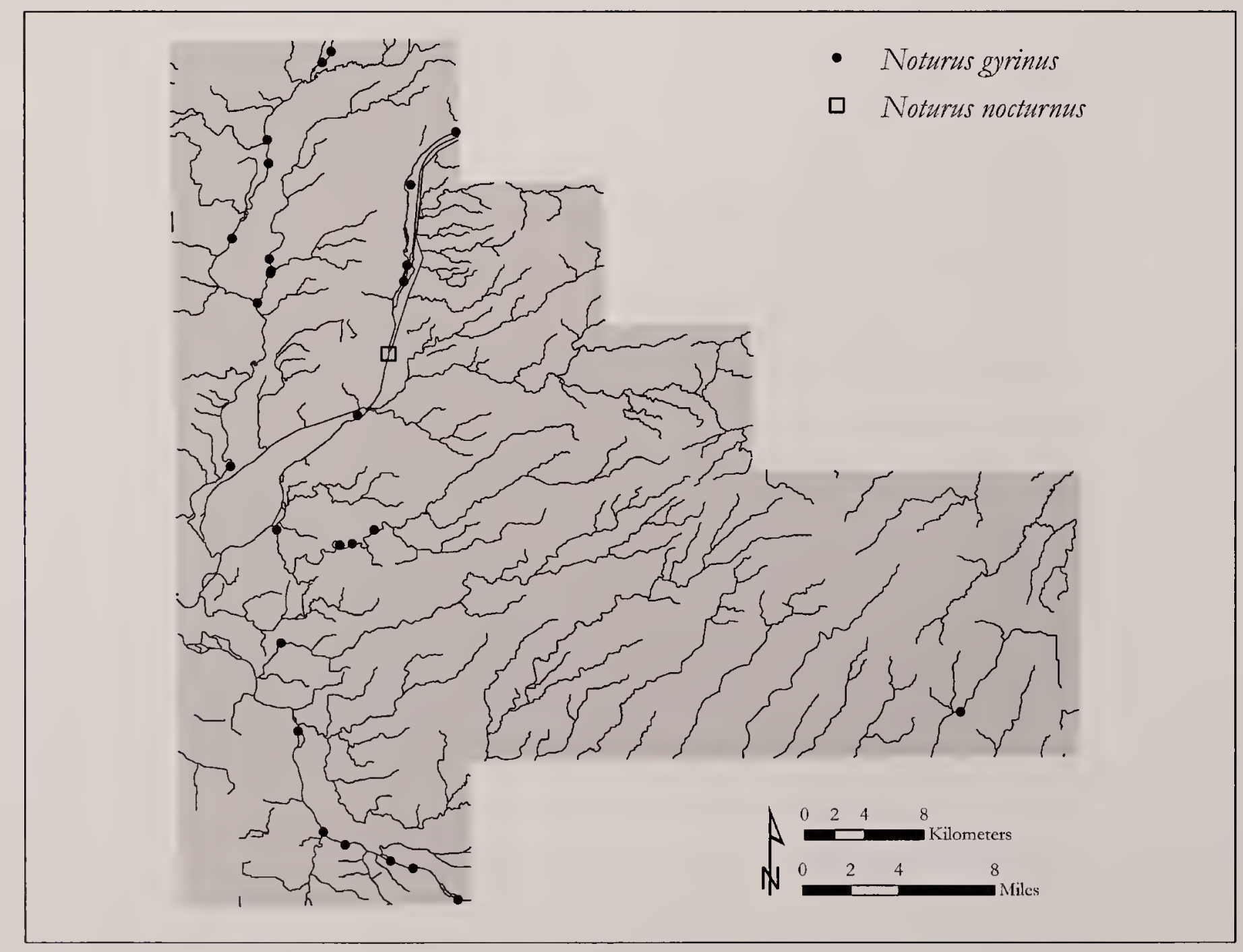

FIG. 64. Distribution of Noturus gyrinus (Tadpole Madtom) and Noturus nocturnus (Freckled Madtom) in Will County, Illinois. 


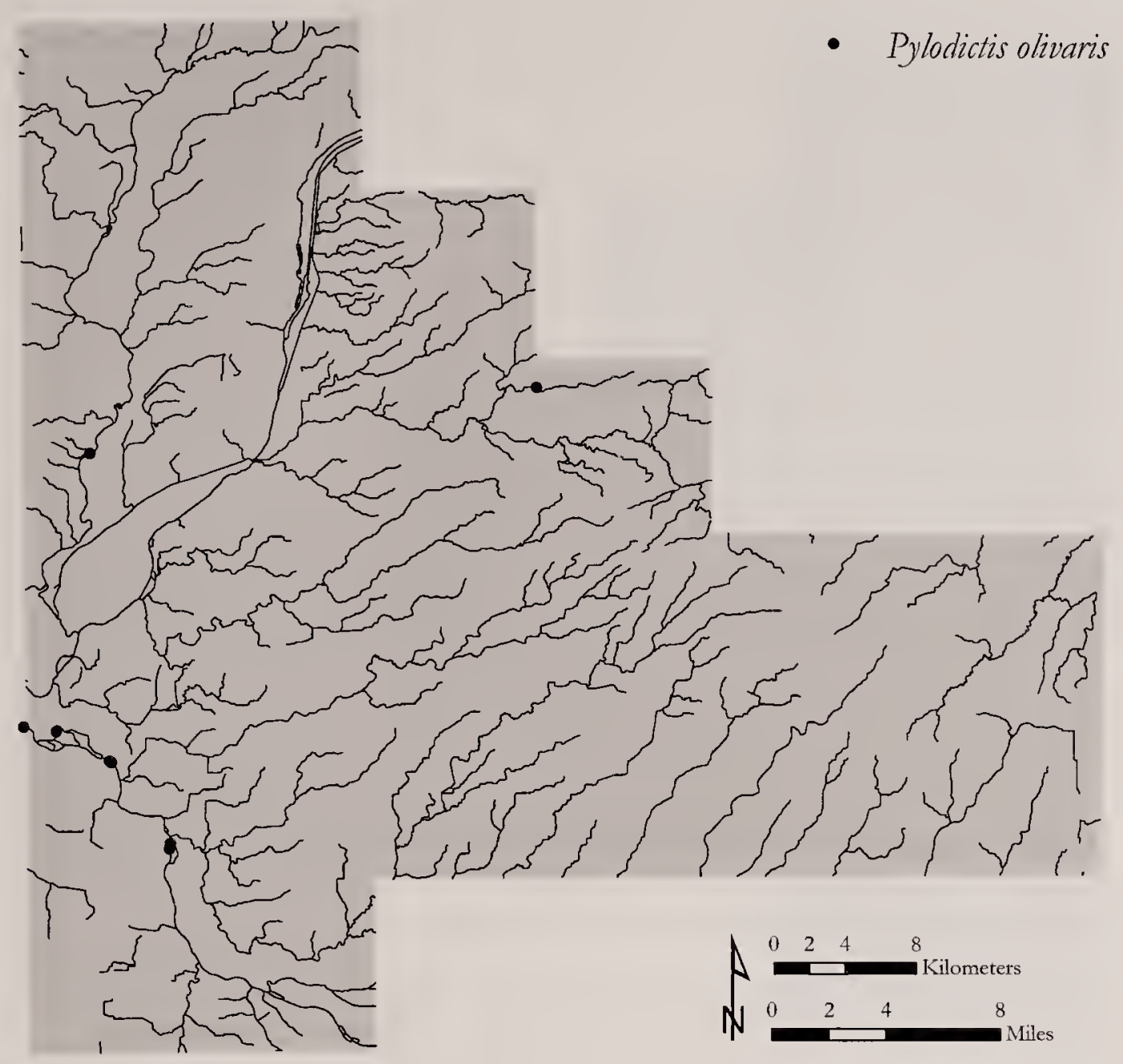

FIG. 65. Distribution of Pylodictis olivaris (Flathead Catfish) in Will County, Illinois.

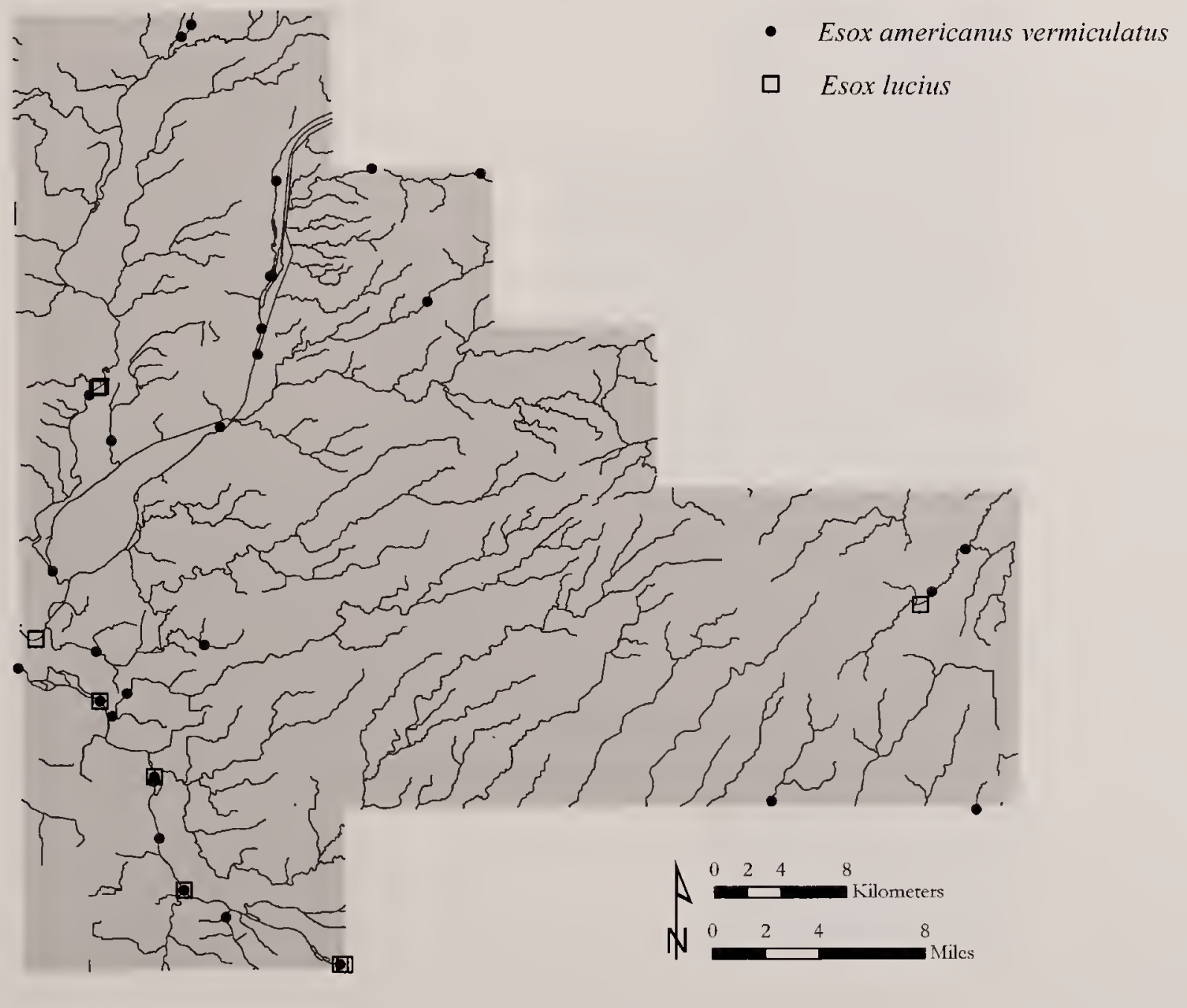

FIG. 66. Distribution of Esox americanus vermiculatus (Grass Pickerel) and Esox lucius (Northern Pike) in Will County, Illinois. 


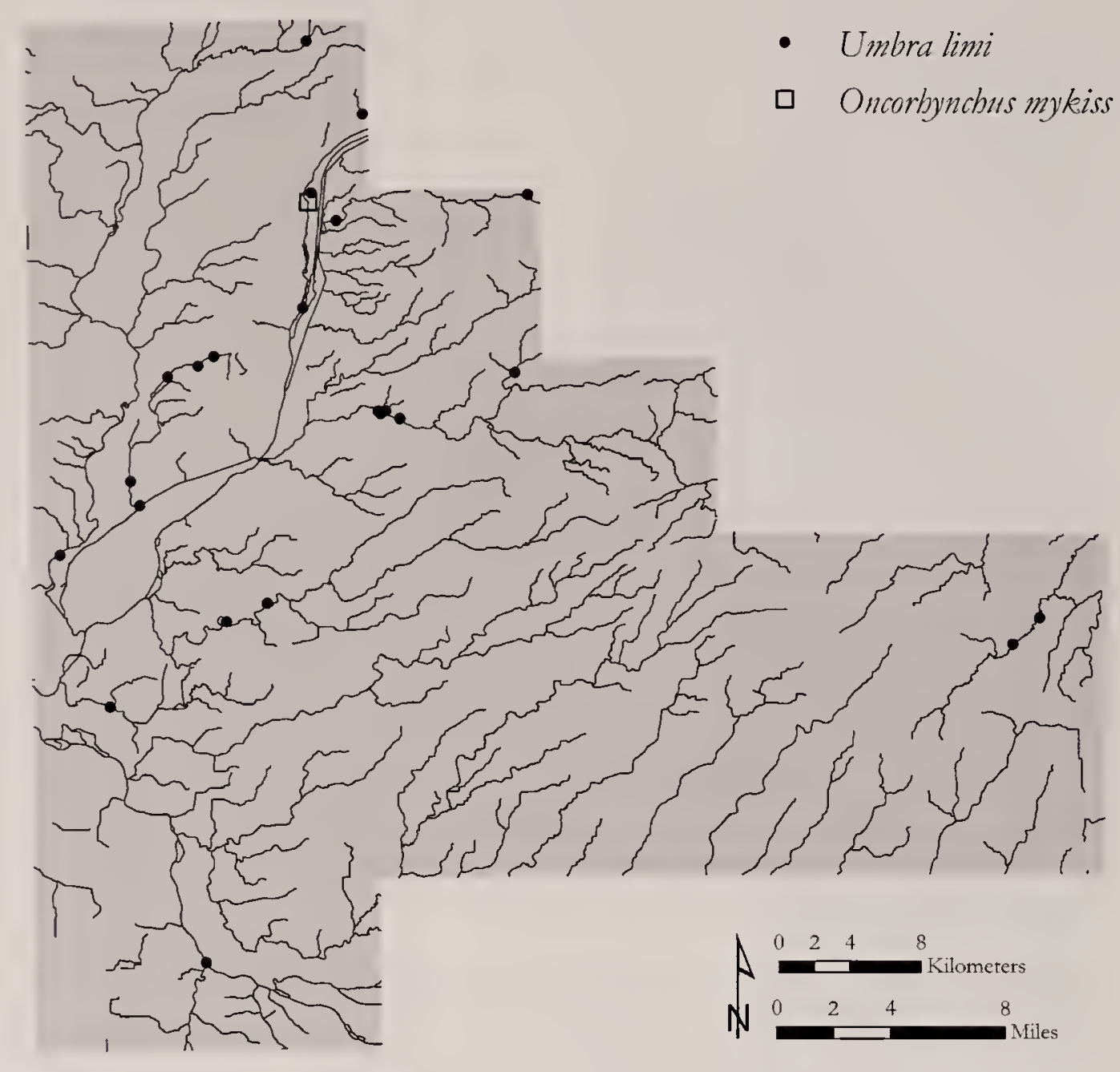

FIG. 67. Distribution of Ullbba limi (Central Mudminnow) and Oncorllynclus nlykiss (Rainbow Trout) in Will County, Illinois.

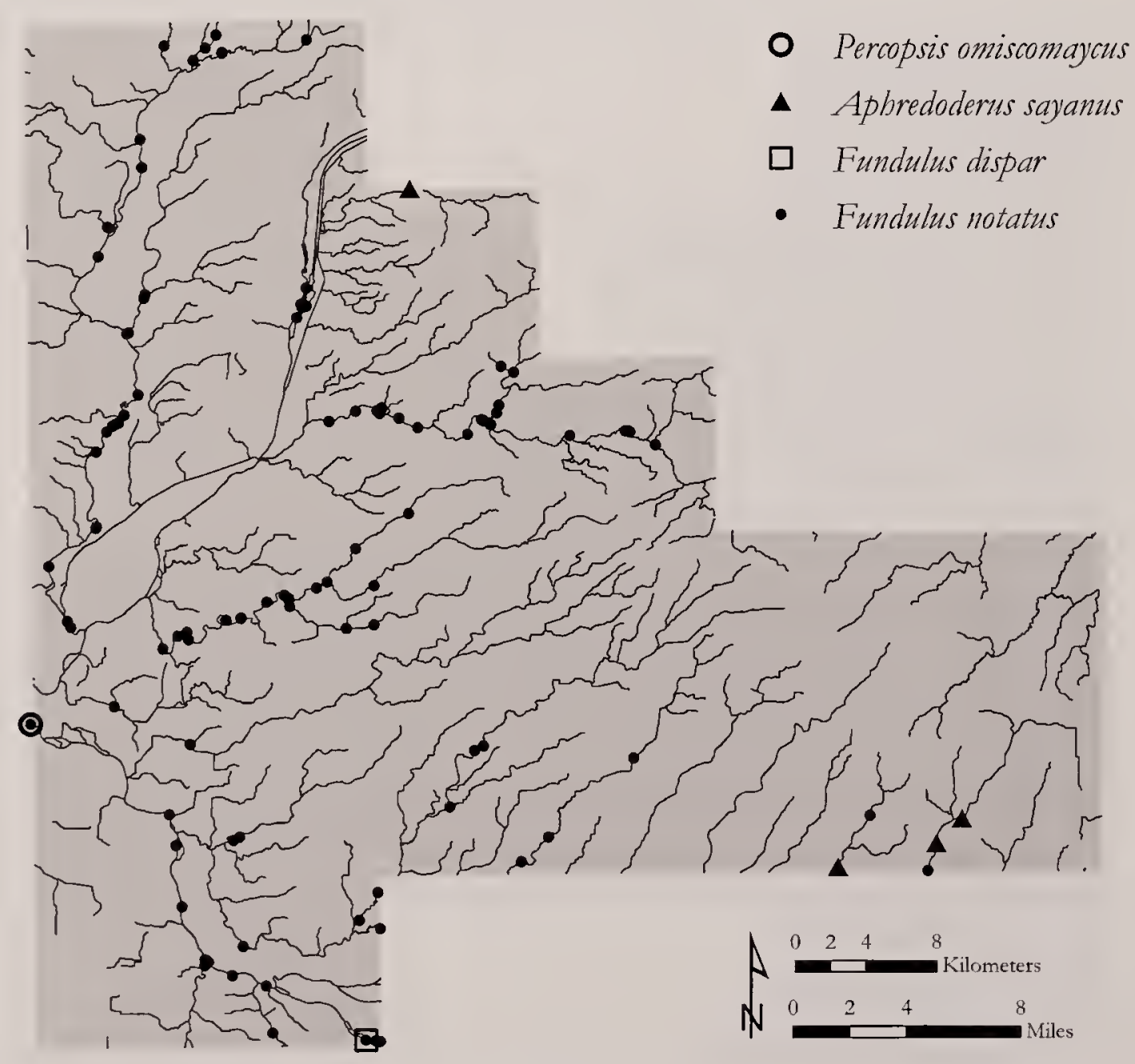

FIG. 68. Distribution of Percopsis omisconaycus (Trout-Perch), Apluredoderus sayanus (Pirate Perch), Fundlulus dispar (Starhead Topminnow), and Fundulus uotatus (Blackstripe Topminnow) in Will County, Illinois. 


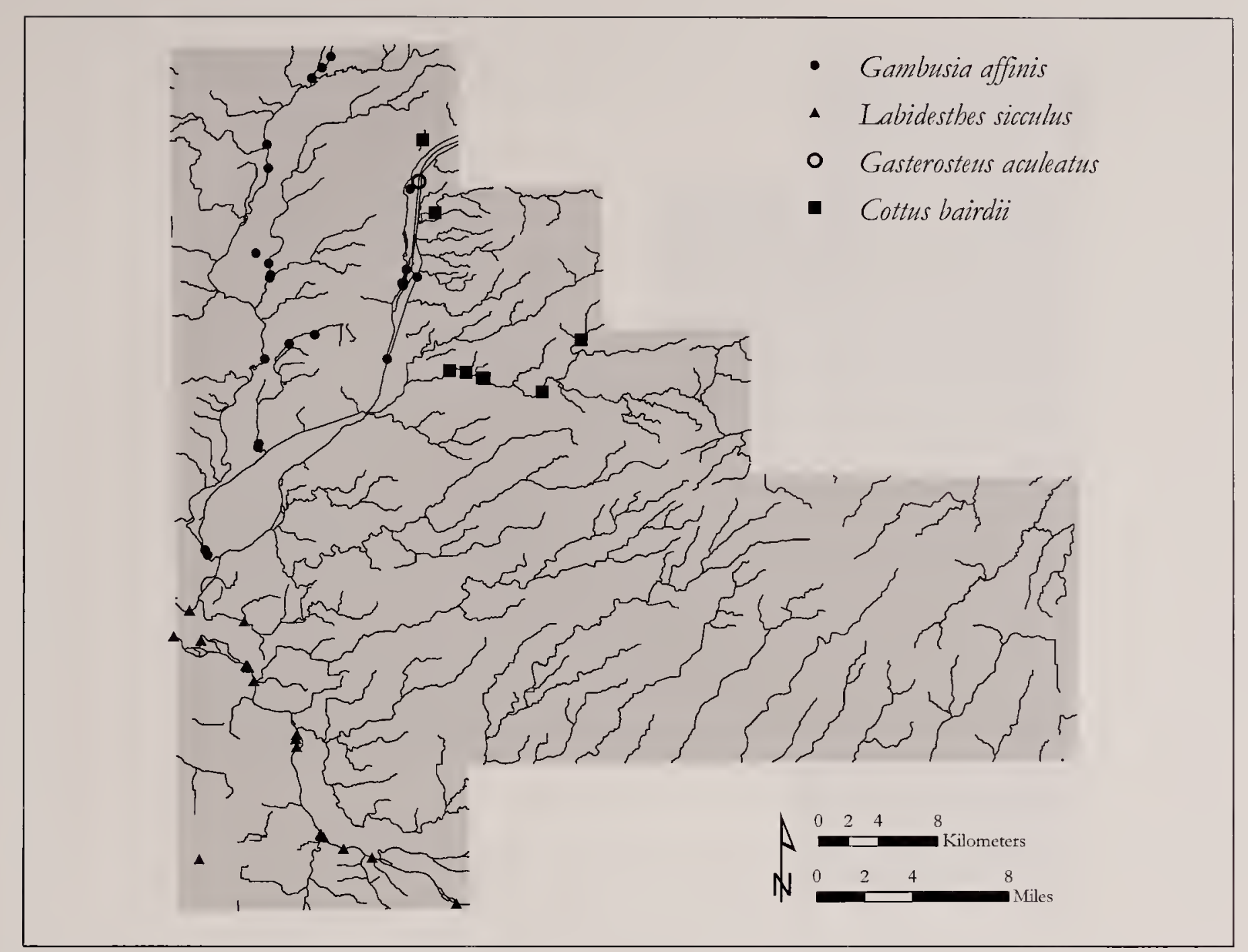

FIG. 69. Distribution of Gambusia affinis (Mosquito Fish), Labidesthes sicculus (Brook Silverside), Gasterostells aculeatus (Threespine Stickleback), and Cottus bairdii (Mottled Sculpin) in Will County, Illinois.

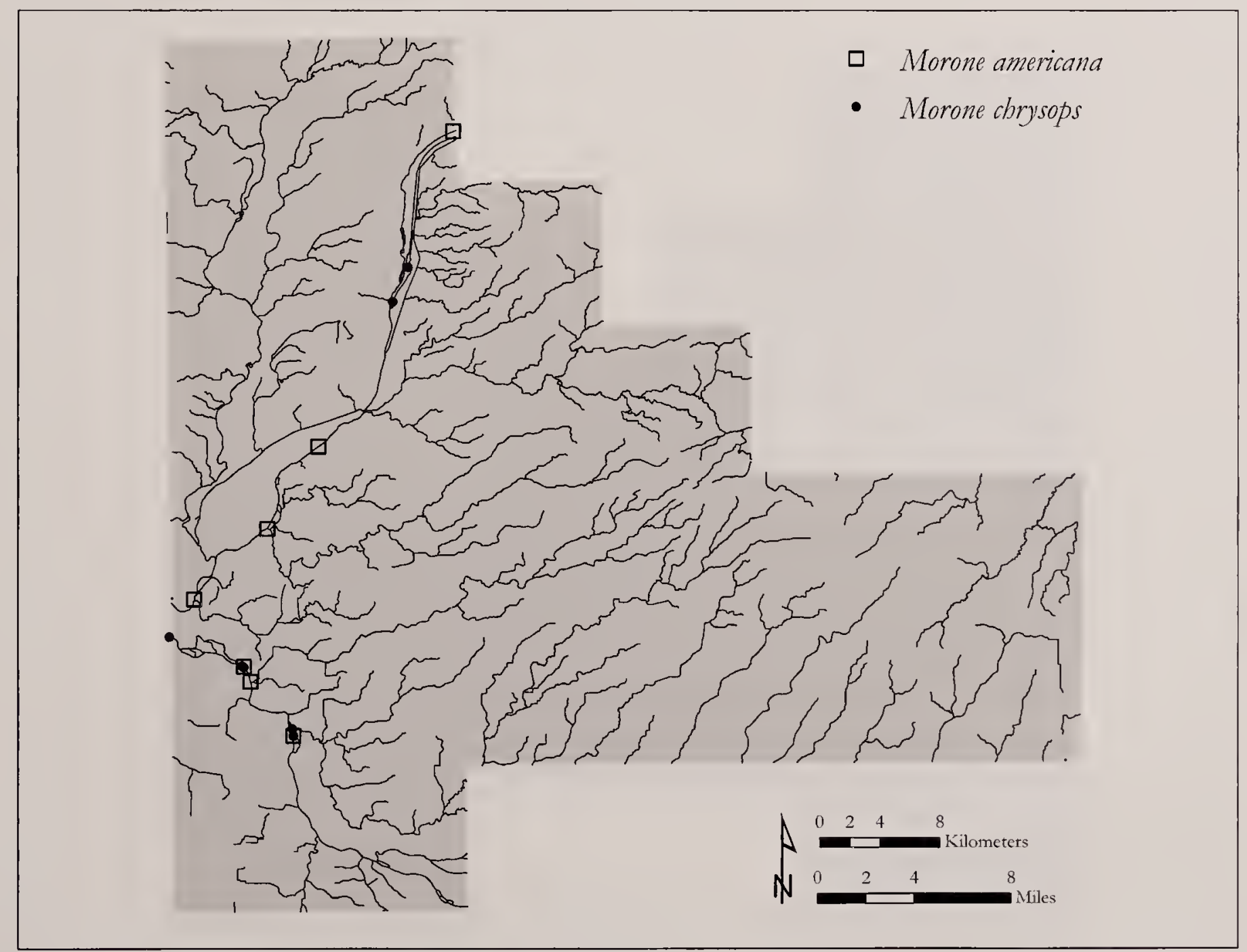

FIG. 70. Distribution of Morone anericana (White Perch) and Morone clerysops (White Bass) in Will County. Illinois. 


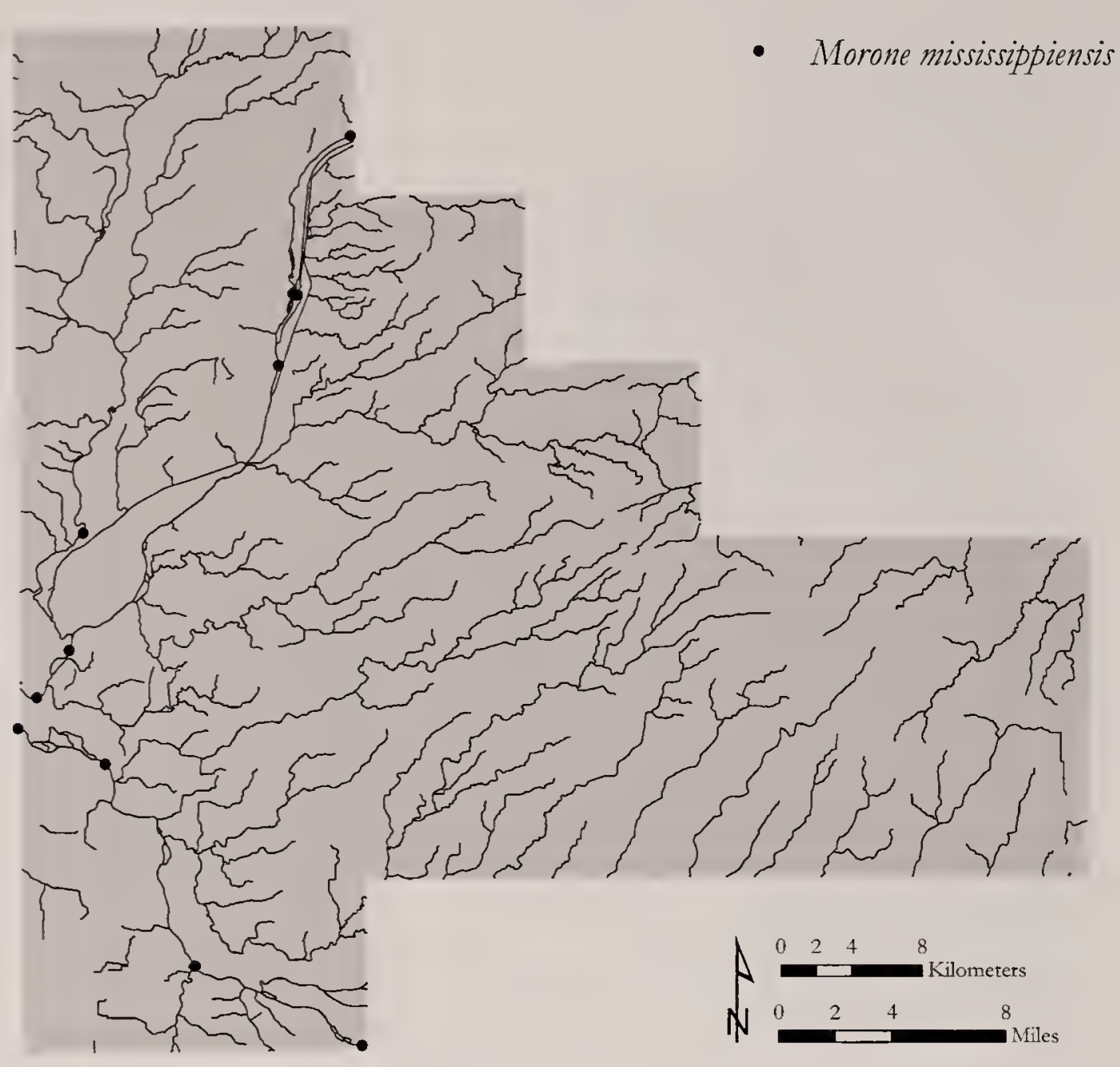

FIG. 71. Distribution of Morone mississippiensis (Yellow Bass) in Will County, Illinois.

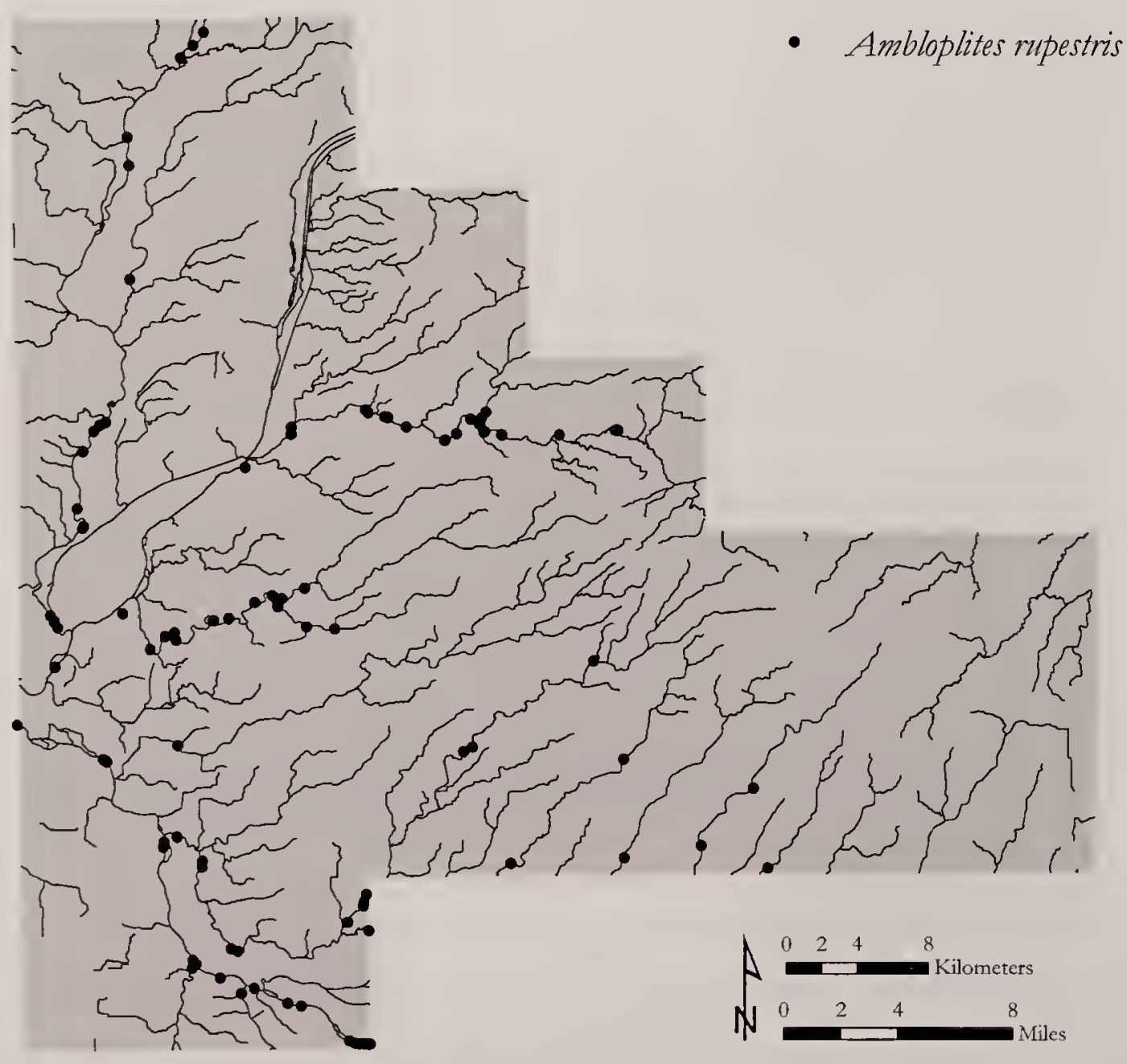

FIG. 72. Distribution of Ambloplites rupestris (Rock Bass) in Will County, Illinois. 


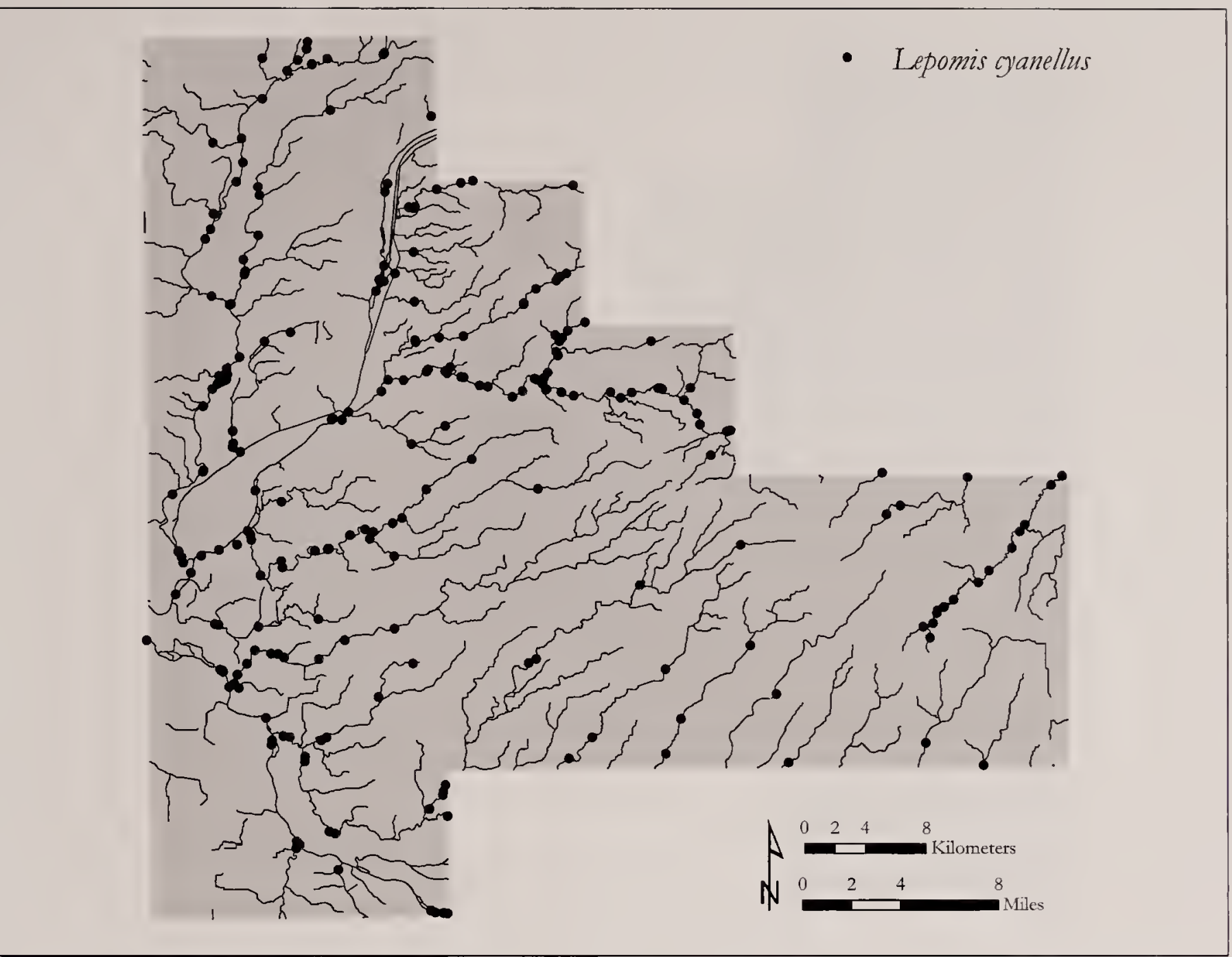

FIG. 73. Distribution of Lepomis cyanellus (Green Sunfish) in Will County, Illinois.

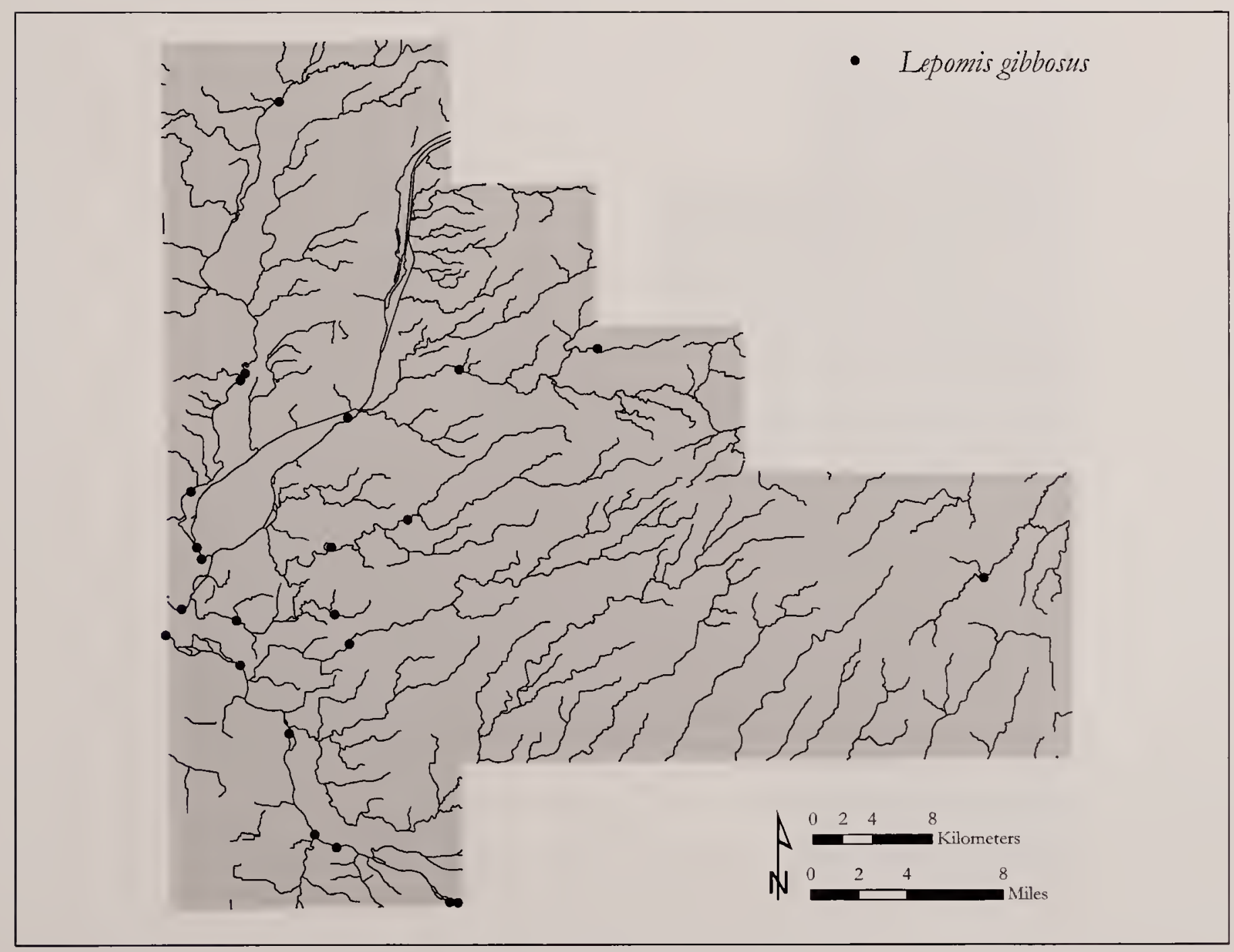

FIG. 74. Distribution of Lepomis gibbosus (Pumpkinseed) in Will County, Illinois. 


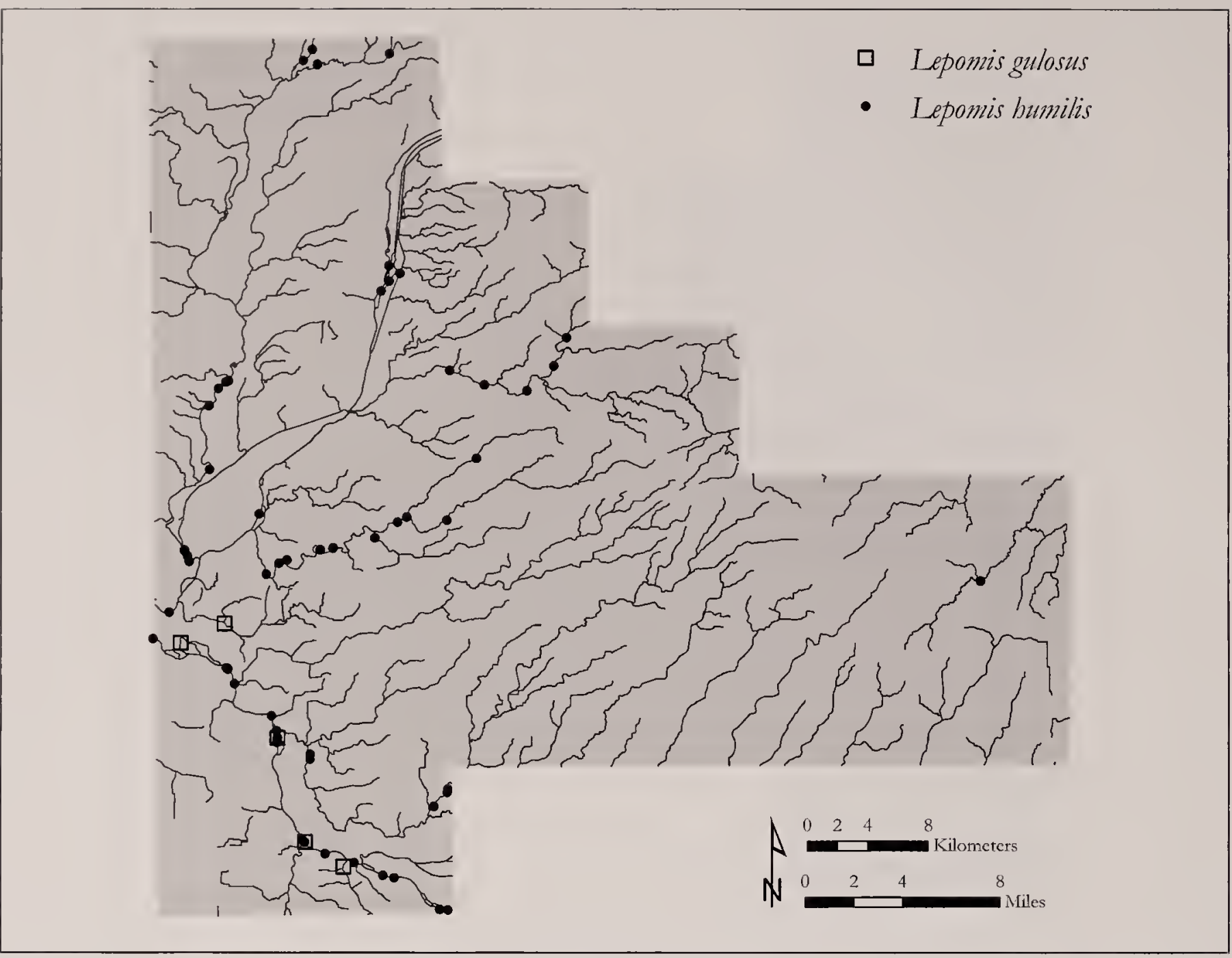

Fig. 75. Distribution of Lepomis gulosus (Warmouth) and Lepomis humilis (Orangespotted Sunfish) in Will County, Illinois.

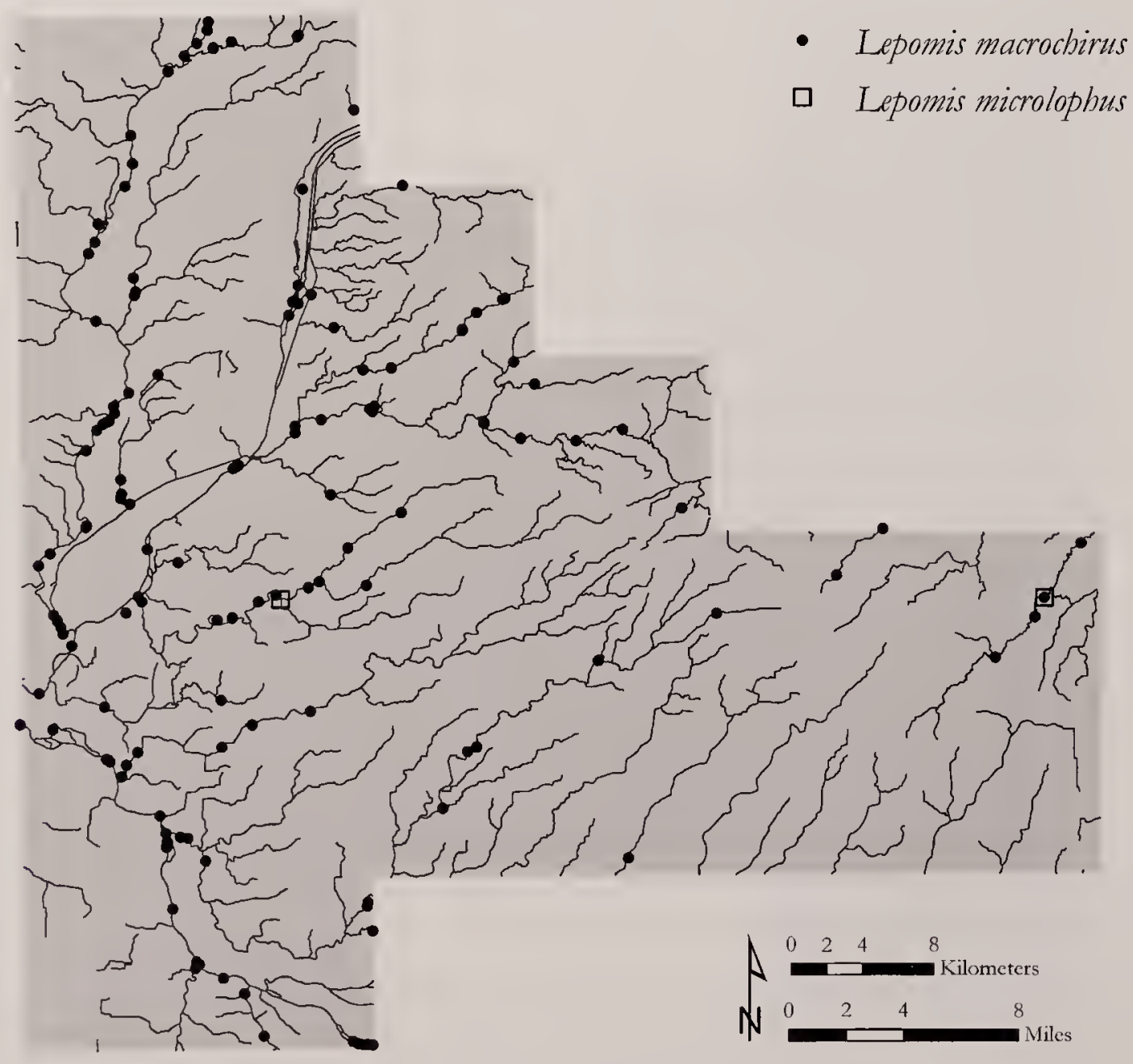

FiG. 76. Distribution of Lepomis macrochirus (Bluegill) and Leponis microlophus (Redear Sunfish) in Will County, Illinois. 


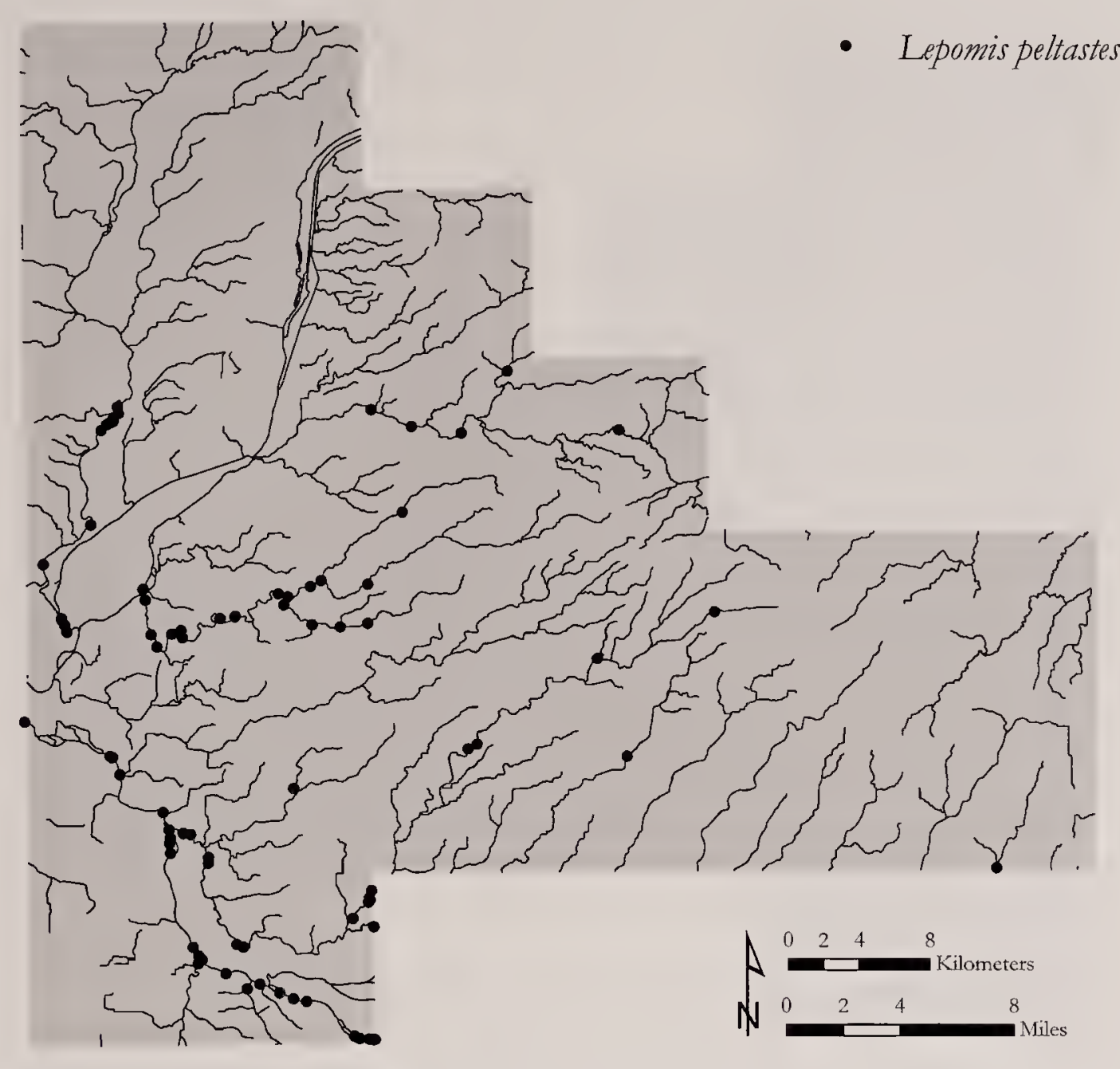

FIG. 77. Distribution of Lepomis peltastes (Northern Longear Sunfish) in Will County, Illinois.

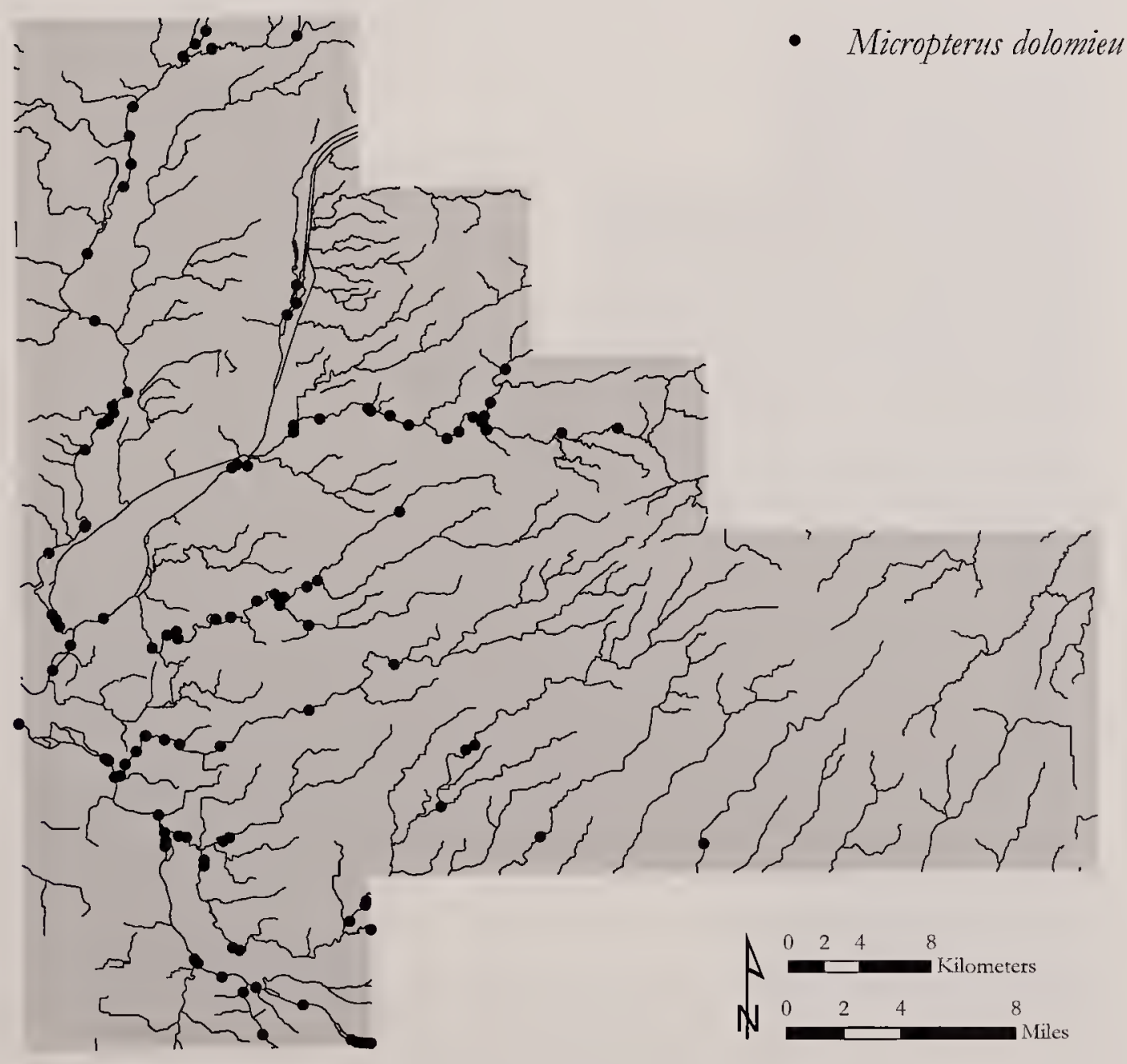

Fig. 78. Distribution of Micropterus dolomieu (Smallmouth Bass) in Will County, Illinois. 


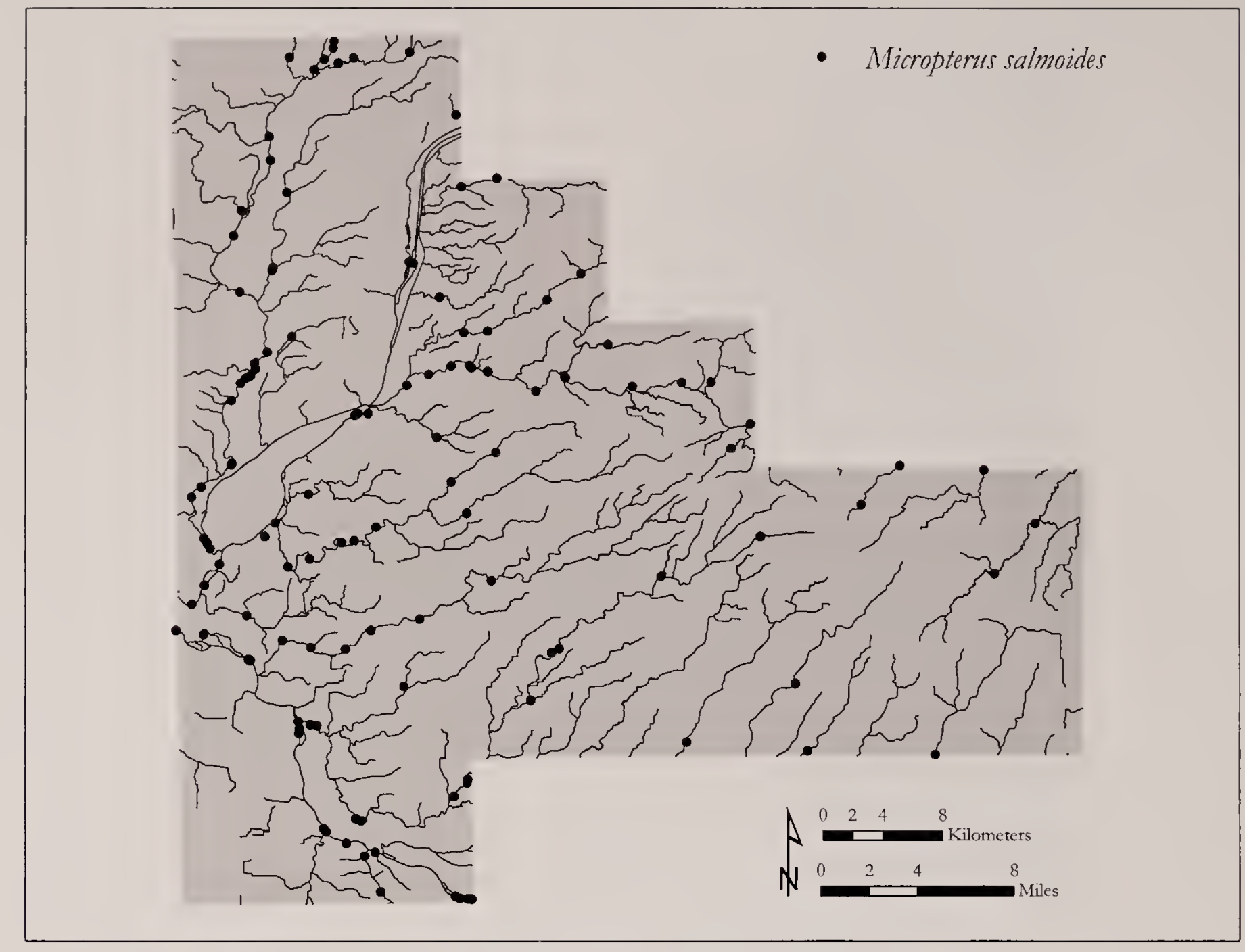

FIG. 79. Distribution of Micropterus salmoides (Largemouth Bass) in Will County, Illinois.

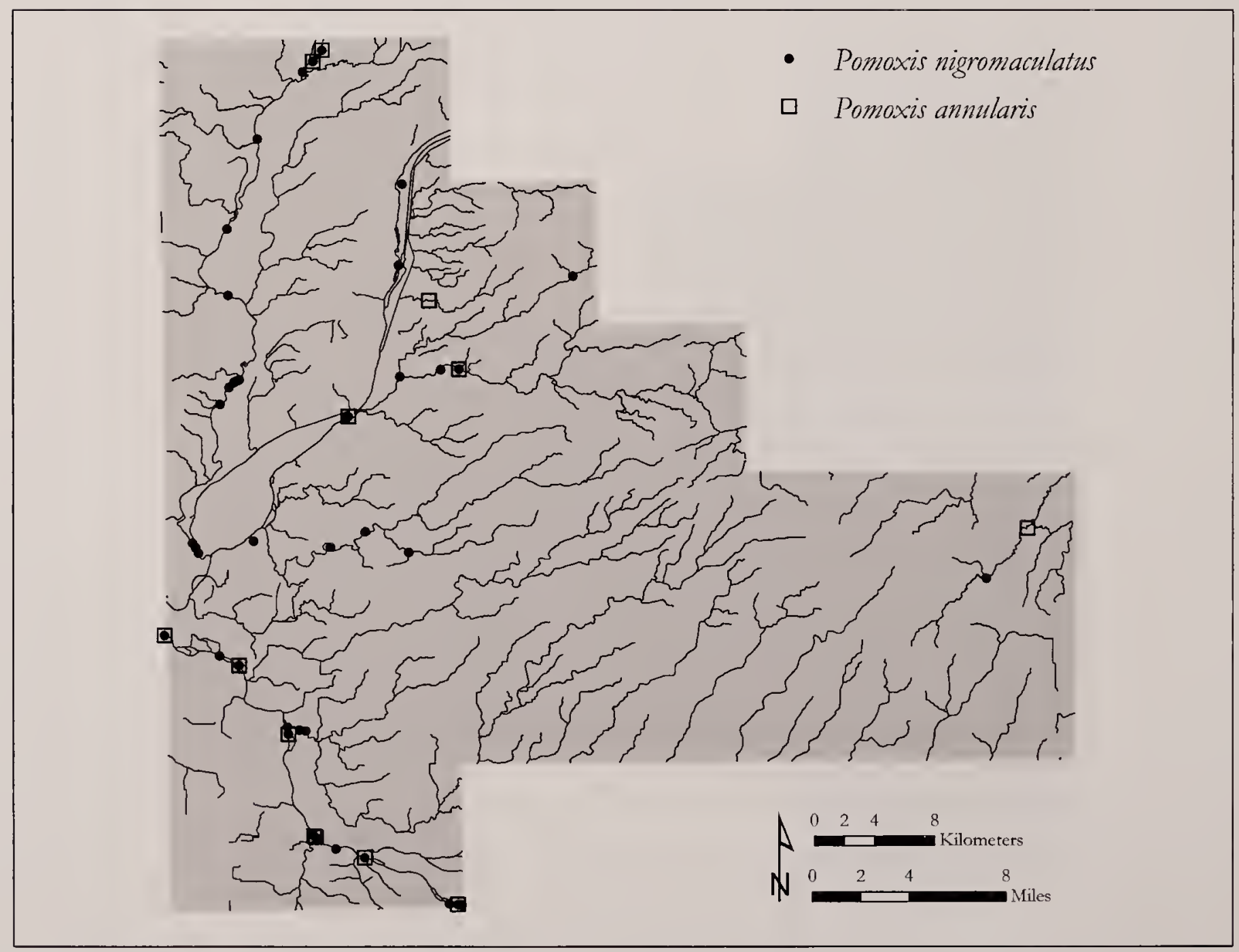

FIG. 80. Distribution of Pomoxis annularis (White Crappie) and Pomoxis nigromaculatus (Black Crappie) in Will County, Illinois. 


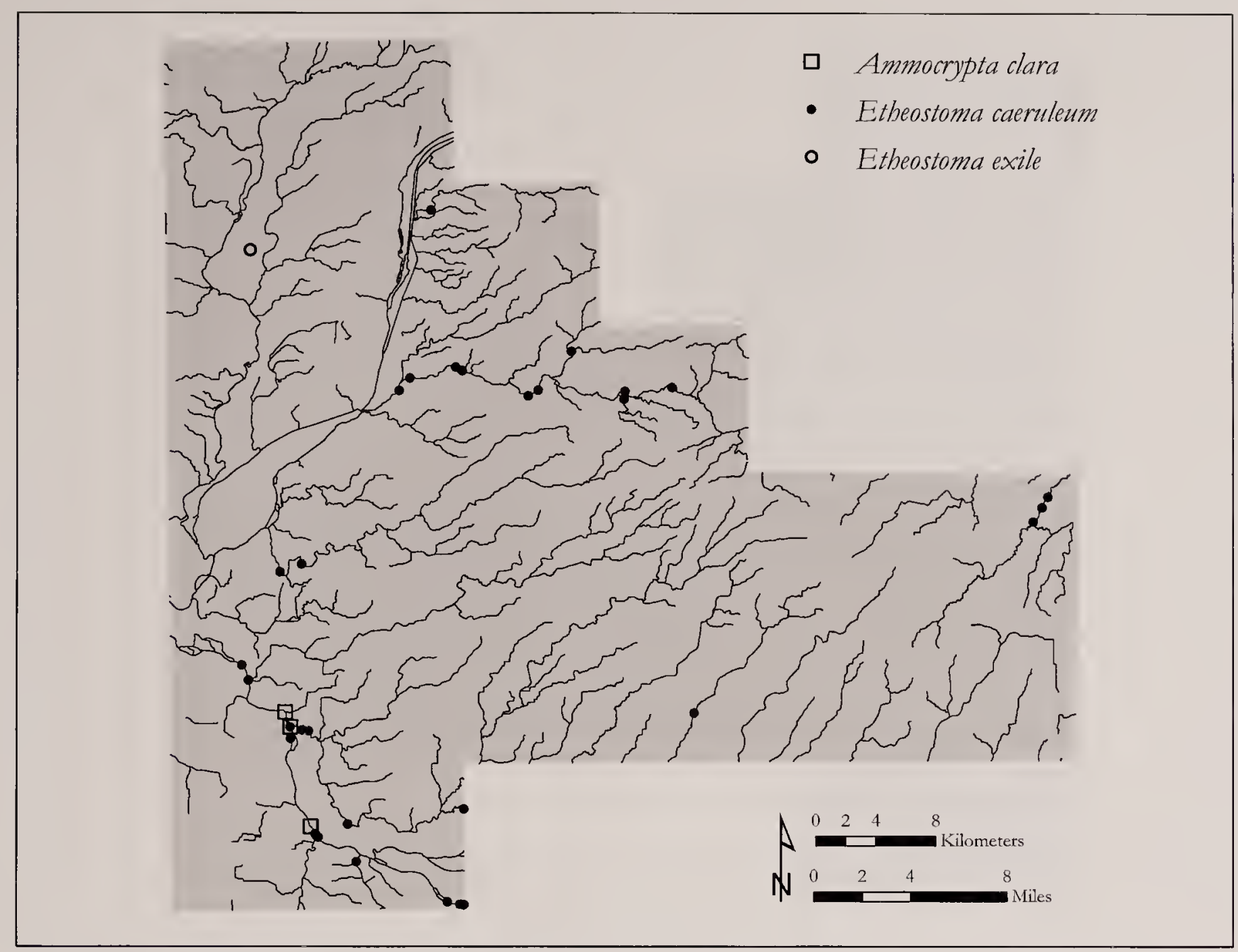

Fig. 81. Distribution of Ammocrypta clara (Western Sand Darter), Etheostoma caeruleum (Rainbow Darter), and Etheostoma exile (Iowa Darter) in Will County, Illinois.

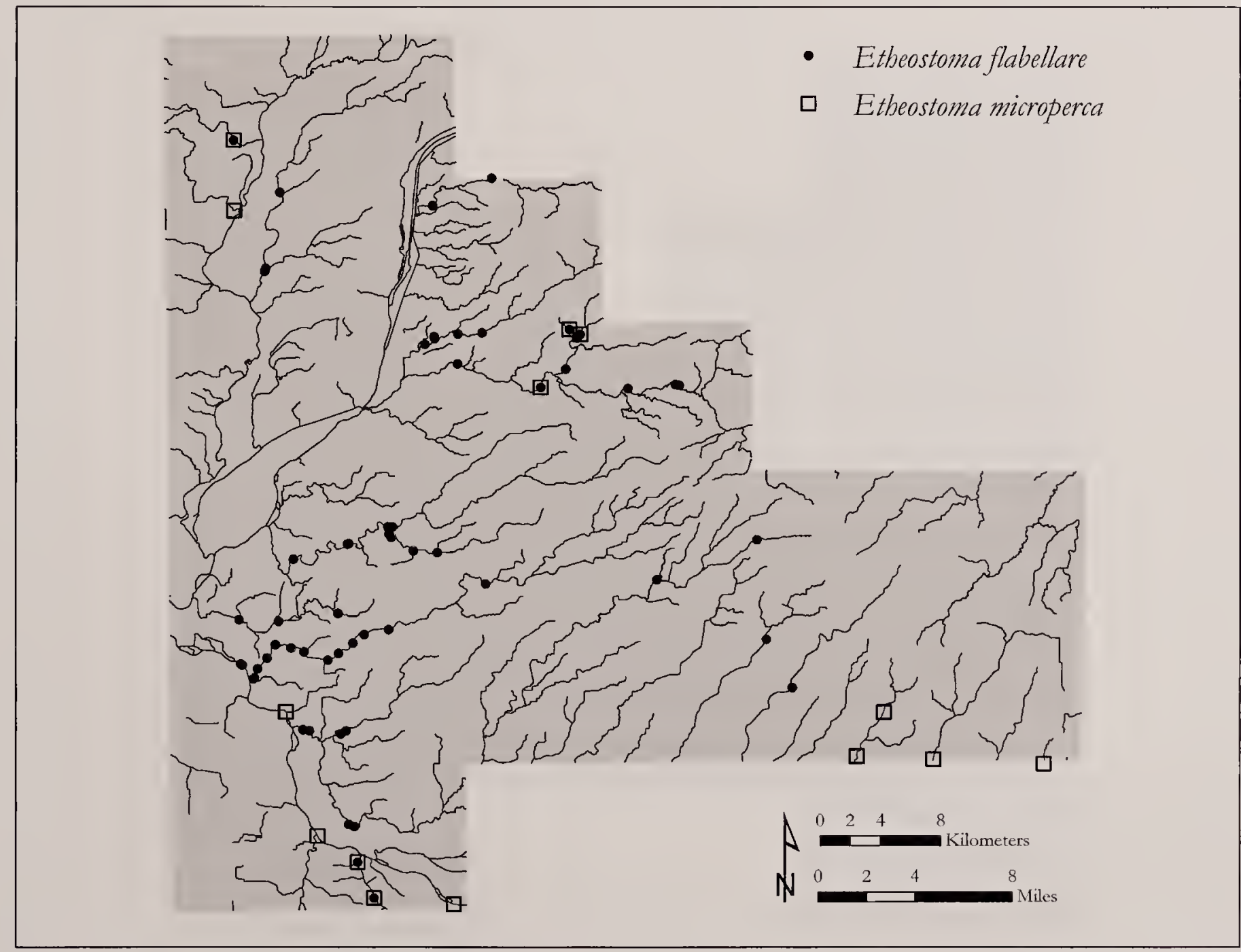

FiG. 82. Distribution of Etheostoma flabellare (Fantail Darter) and Etheostoma microperca (Least Darter) in Will County, Illinois. 


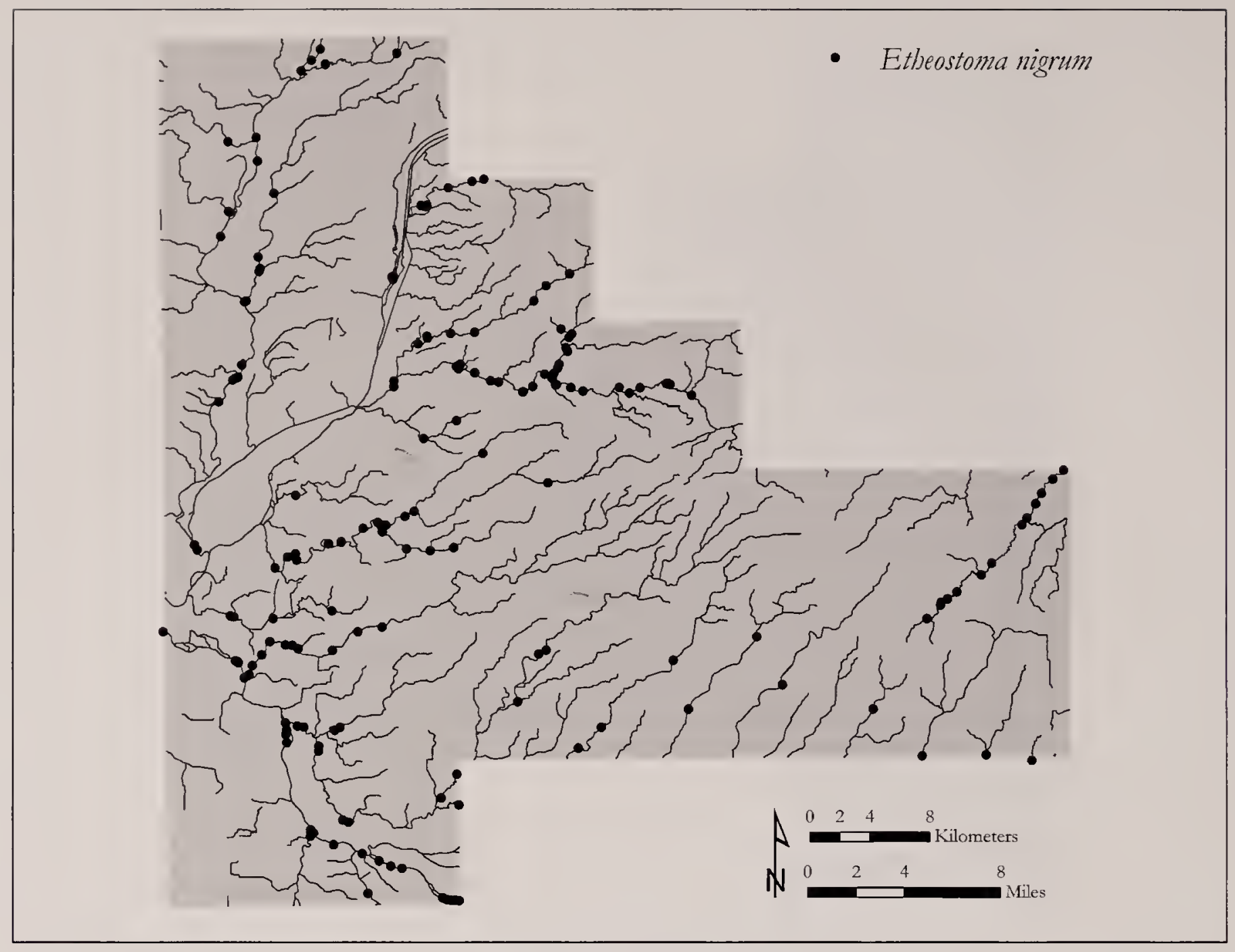

FIG. 83. Distribution of Etheostoma nigrum (Johnny Darter) in Will County, Illinois.

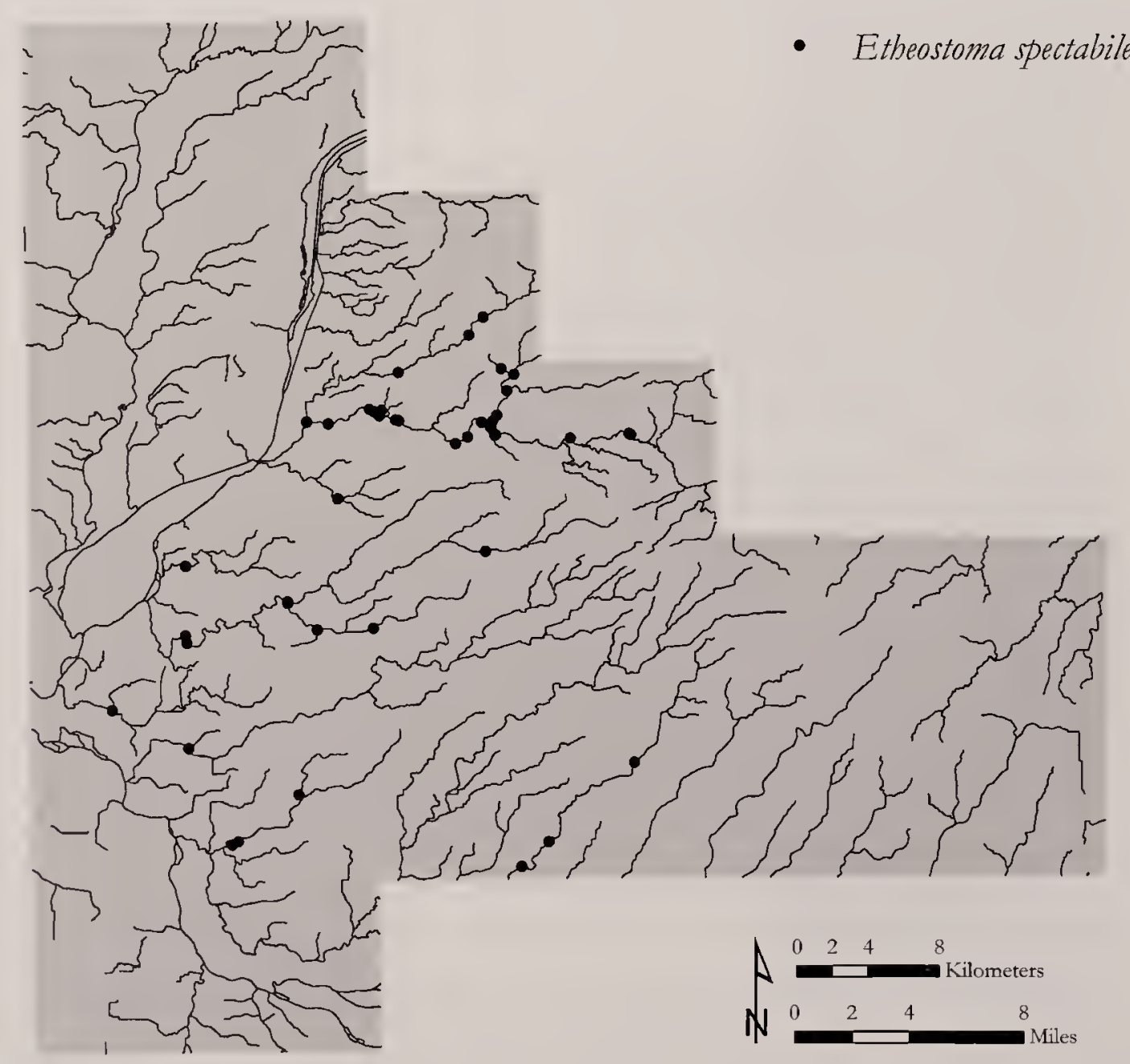

FIG. 84. Distribution of Etheostoma spectabile (Orangethroat Darter) in Will County, Illinois. 


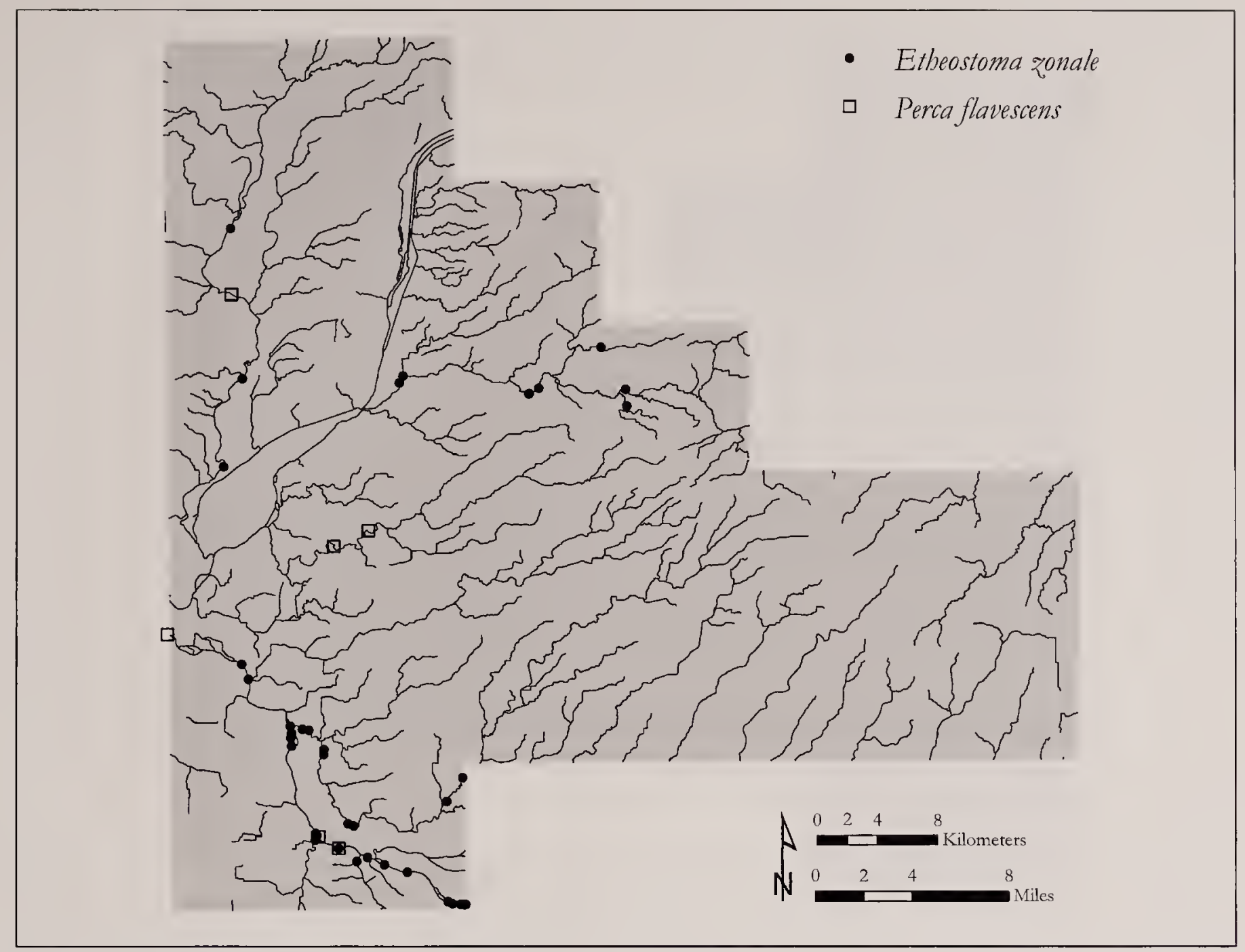

FIG. 85. Distribution of Etheostoma zonale (Banded Darter) and Perca flavescens (Yellow Perch) in Will County, Illinois.

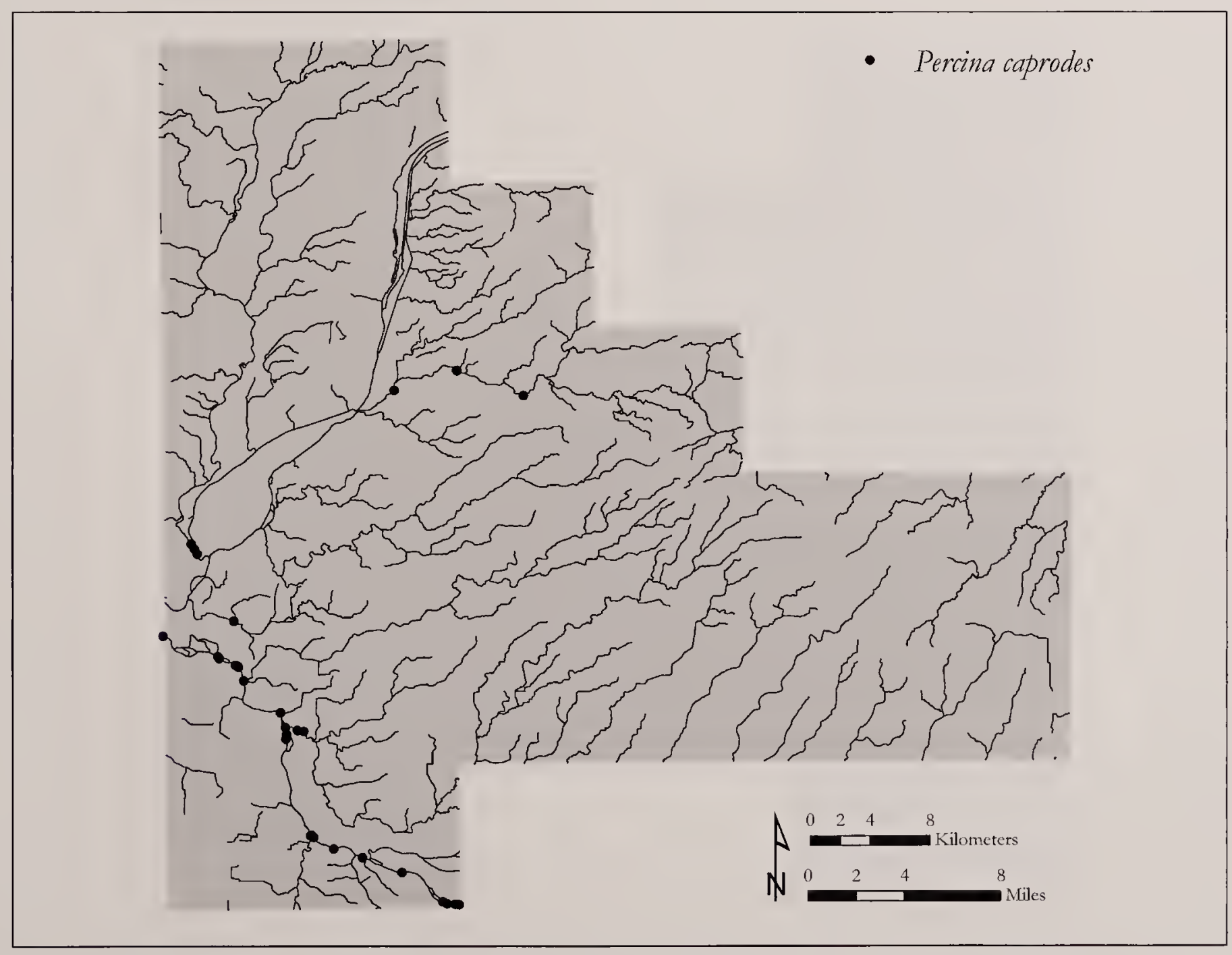

FIG. 86. Distribution of Percina caprodes (Logperch) in Will County, Illinois. 


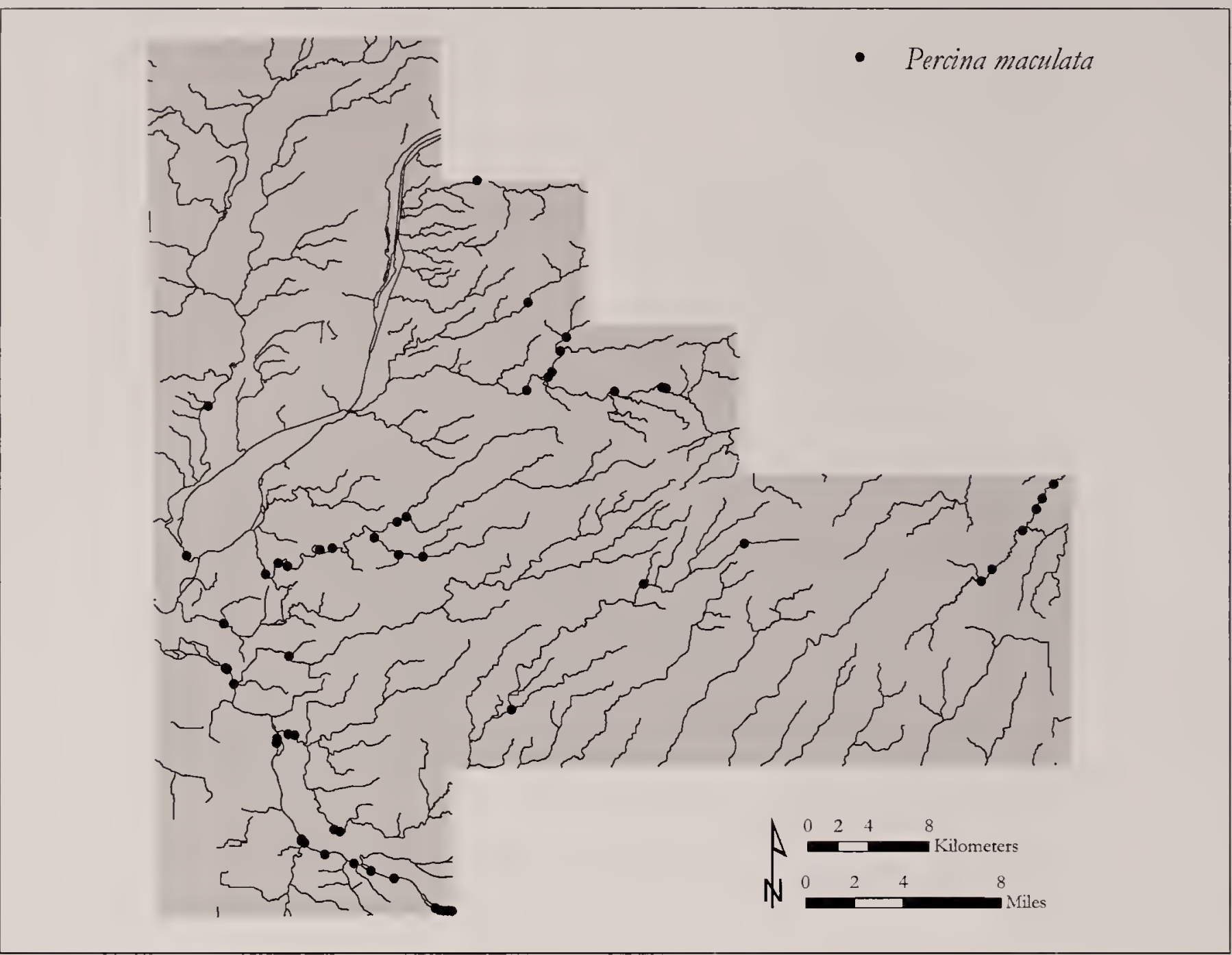

FIG. 87. Distribution of Percina maculata (Blackside Darter) in Will County, Illinois.

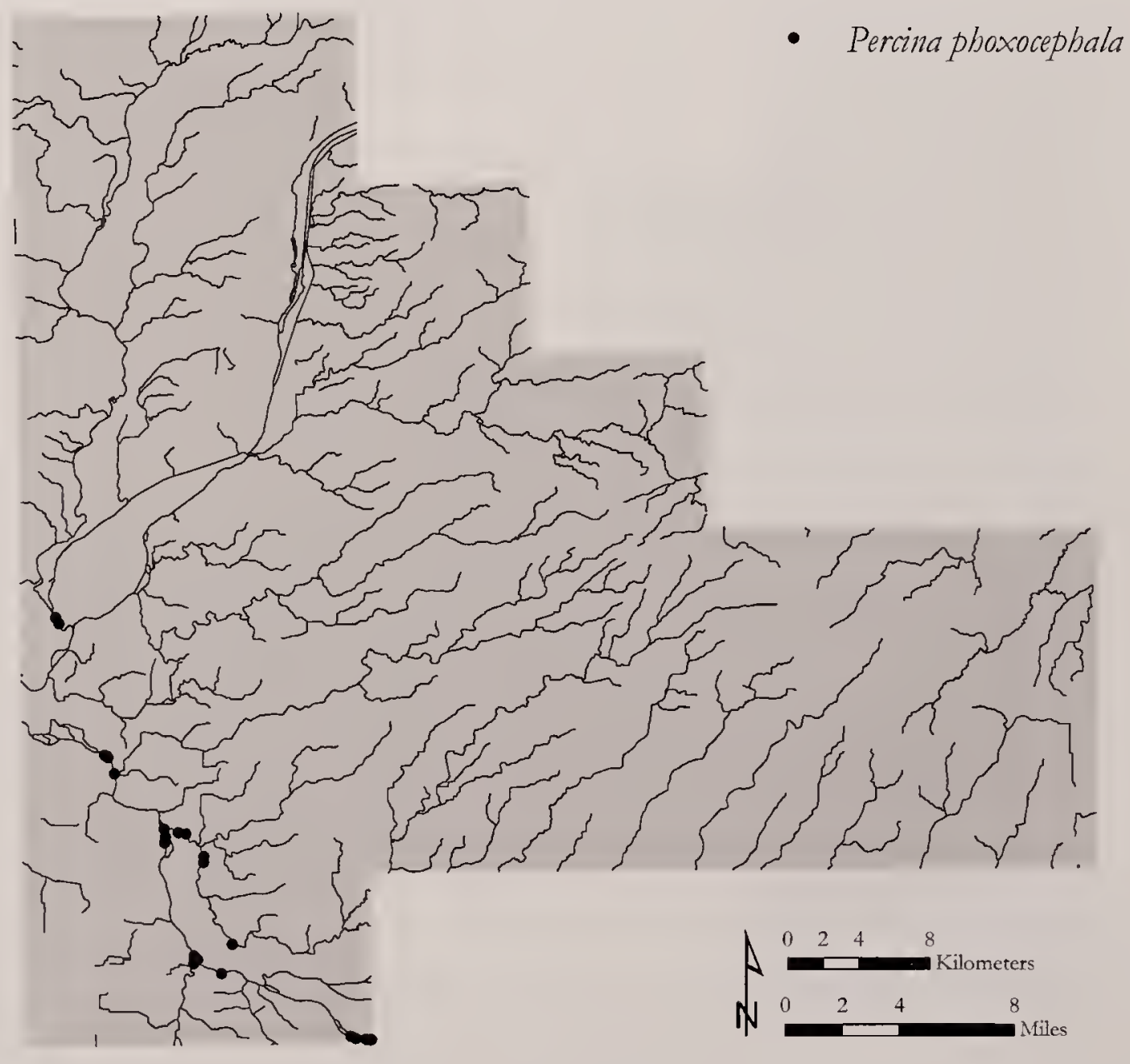

FIG. 88. Distribution of Percina phoxocephala (Slenderhead Darter) in Will County, Illinois. 


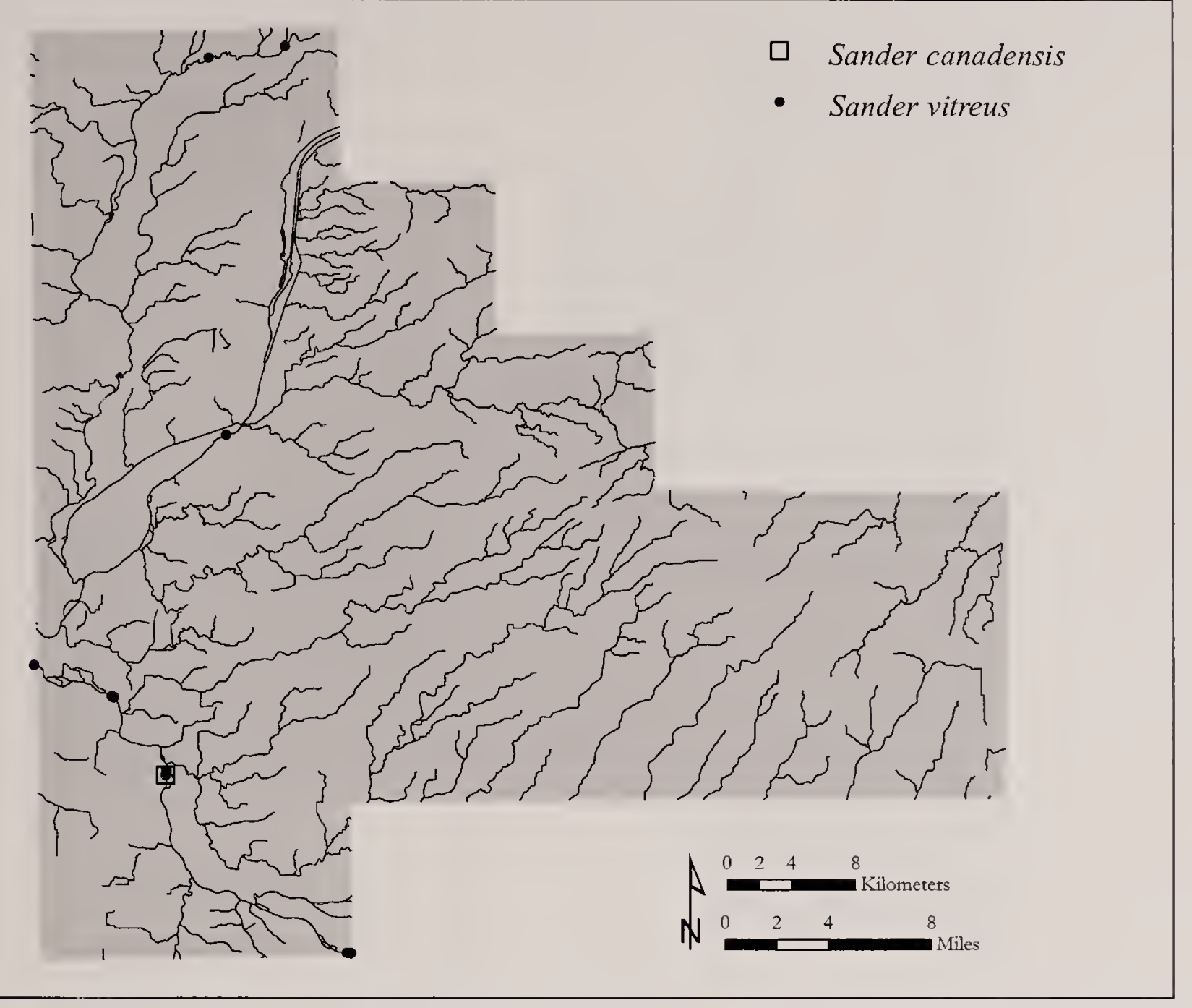

FIG. 89. Distribution of Sander canadensis (Sauger) and Sander vitreus (Walleye) in Will County, Illinois.

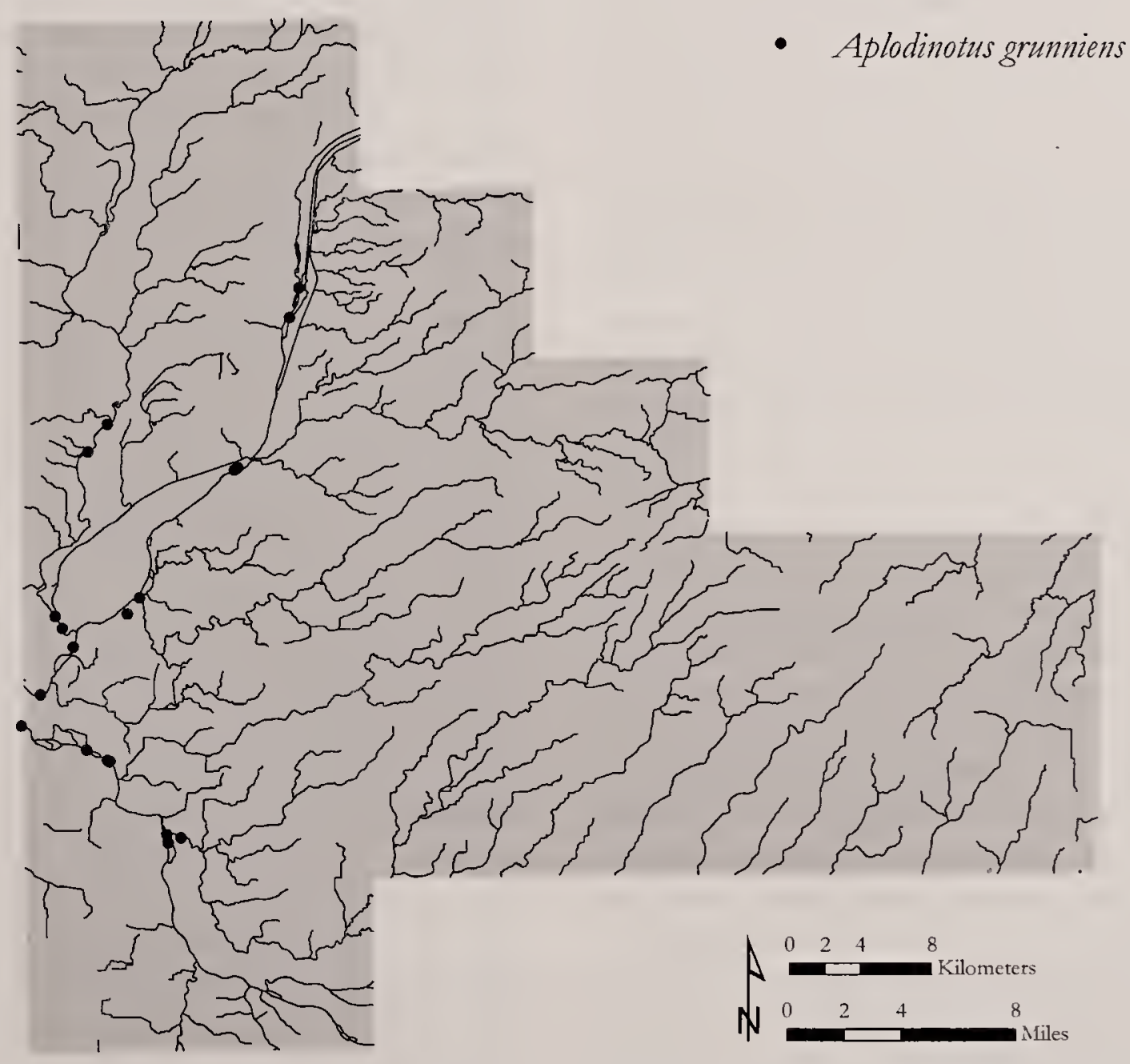

FIG. 90. Distribution of Aplodinotus grunniens (Freshwater Drum) in Will County, Illinois. 


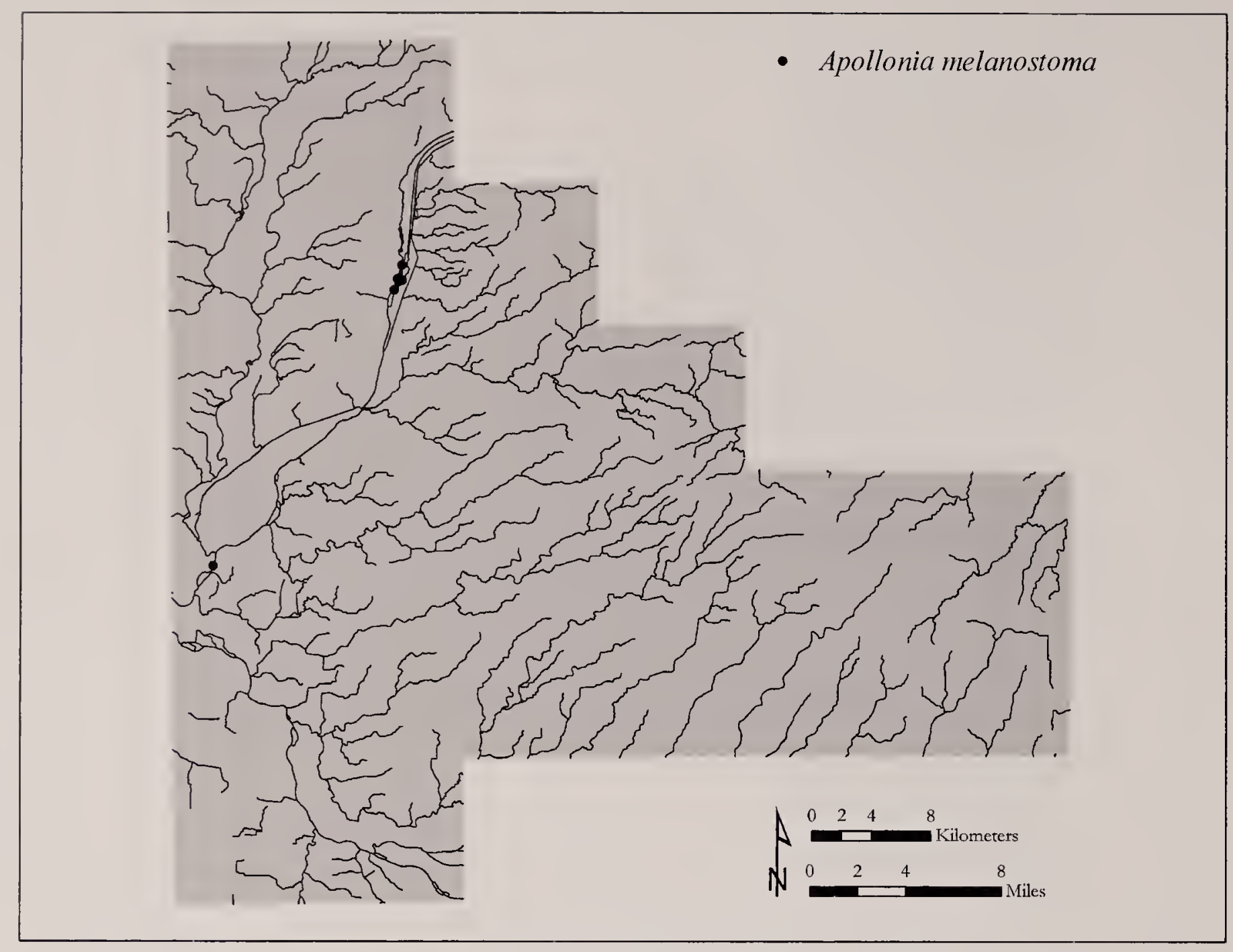

FIG. 91. Distribution of Apollonia melanostoma (Round Goby) in Will County, Illinois.

annularis White Crappie, A. melas, and Esox americanus vermiculatus Grass Pickerel.

Water levels in marshes and backwaters can fluctuate seasonally. Some backwaters dry completely, and others may have isolated pools. Only fishes that can tolerate low oxygen levels, like Umbra limi Central Mudminnow and Pimepliales promelas Fathead Minnow, survive in these pools. If the pools are large in size or are partially connected to other bodies of water, then additional species are possible, such as $E$. $a$. vermiculaus, C. commersonii, Cyprinus carpio Common Carp, Fundulus notatus Blackstripe Topminnow, A. melas, Carassiuls auratus Goldfish, Notemigonus crysoleucas Golden Shiner, and Fundulus dispar Starhead Topminnow. Juvenile fishes are common in backwaters in spring because they offer abundant food and hiding places. Most juvenile fishes leave backwaters during the early summer, before water levels drop too low.

\section{Comments on Select Watersheds}

Great Lakes Drainage-Plum Creek-The diversity of fishes in Plum Creek is above average for such a fragmented system. Many are typical creek species for the region. The darters Etheostoma nigrum and Percina maculata are present, with $E$. nigrum being particularly abundant, indicating clean gravel bottoms and limited sedimentation. Umbra limi Central Mudminnow are in the creek proper and nearby wetlands. There appears to be an isolated population of Luxilus cornutus Common Shiner in Plum Creek. Luxilus clirysocephalus Striped Shiner is the more common of these two species in Will County. The L. cornutus specimens taken from Plum Creek show possible signs of hybridization with $L$. chrysoceplatus. Leslie (1989) documented a decrease in diversity of fishes from 1980 to 1989. Flow alteration and habitat degradation were implicated as causative factors, particularly near an upstream landfill, but other factors were probably at work as well. The fish assemblage of Plum Creek is essentially isolated by the poor water quality and environmental degradation of the contiguous Hart Ditch and Little Calumet River. If the fishes of Plum Creek were eliminated, there would be no recolonization of sensitive species, and they would be replaced by common species. Nocomis micropogon River Chub (Illinois endangered species) has been reported from Plum Creek, but we were unable to verify this record and believe it is a likely misidentification of Nocomis biguttatus Hornyhead Chub.

Des Plaines River Drainage-Des Plaines River-The diversity of fishes in the Des Plaines River is respectable but not as high as we would expect given the river's variety of habitats. This is possibly due to pollution and habitat degradation. However, water quality appears to be improving, and fishes are slowly returning. This is exemplified by the collection of Noturus nocturnus Freckled Madtom (FMNH Z19815) in 2005 by Francis Veraldi and James Ladonski. It is the first time in over 100 years that this madtom catfish has been found this close to Chicago and is hopefully a harbinger of a bright future for the Des Plaines River (Bowman, 2005; Retzer, 2005; Parker, 2006; Willink et al., 2006). Wetlands, like Lockport Prairie, are particularly critical because they act as nurseries for fishes and hence provide the "seeds" that will repopulate the rest of the watershed. Unfortunately, the invasive Apollonia melanostoma Round Goby and Misgurnus anguillicaudatus Oriental Weatherfish are established and spreading throughout the Des Plaines drainage.

DuPage River-The DuPage River has a respectable diversity of fishes but not as many as we would expect for a watershed of its size and variety of habitats. Some fishes are 
typical river species, like Carpiodes cyprinus Quillback and Dorosoma cepedianum Gizzard Shad. Other river species in the Des Plaines River are unable to access the DuPage River because of the dam near its mouth. Most fishes are creek species, like Catostomus commersonii White Sucker, Cyprinella spiloptera Spotfin Shiner, Luxilus chrysocephalus Striped Shiner, and Notropis dorsalis Bigmouth Shiner. There appears to be a stable population of Luxilus cornutus Common Shiner along the border with DuPage County. This is one of the few populations of $L$. cornutus within Will County. Highly sensitive species appear to be absent, with the exception of Etheostoma exile Iowa Darter (Illinois threatened species) reported from Lake Renwick, Lily Cache Creek drainage. This is the only know population of this species in Will County. Moderately sensitive fishes like Hypentelium nigricans Northern Hog Sucker and Moxostoma Redhorse species are present. Records of Carassius auratus Goldfish, Cyprinus carpio Common Carp, and $C$. auratus X C. carpio hybrids are an indication of poor water quality and habitat degradation. We suspect that the nonnative Apollonia melanostoma Round Goby and Misgurnus anguillicaudatus Oriental Weatherfish will colonize the DuPage River in the near future.

Hickory Creek-Hickory Creek is one of the most analyzed creeks in the Chicago region, which means that its degradation over the past 100 years is well documented. It has appeared in presentation abstracts (e.g., Bruner \& Resetar, 2001), journal articles (e.g., Meek \& Hildebrand, 1910; Shelford, 1911; Woods, 1959; Bland, 1976), books (e.g., Shelford, 1913), reports (e.g., Greenberg, 2003), and at least two master's theses (Molling \& Casey, 1975; Dorkin, 1980). It was once considered a model creek and even partially provided the basis for theories on creek succession (Shelford, 1911, 1913). Later studies found more and more changes in the watershed and fewer species of fishes (Woods, 1959; Molling \& Casey, 1975; Bland, 1976; Dorkin, 1980). Bruner and Resetar (2001) did not find a change in the number of species but did find that certain species were extirpated and replaced by other species. Woods (1959, p. 7) was so discouraged by what he saw that he exclaimed, "I predict that a survey 50 years hence will be so unproductive that no biologist is likely to be interested in making it." Hypothesized reasons for these changes are droughts and floods, channelization, siltation, impoundments, pollution, and housing developments (Woods, 1959; Molling \& Casey, 1975; Bland, 1976; Dorkin, 1980). The actual explanation is probably a mixture of these reasons. Despite the emphasis on degradation, a long history of conservation efforts continues today (Greenberg, 2003). Without these efforts, Hickory Creek could be in even worse shape than its current condition.

The diversity of fishes in Hickory Creek is currently lower than what we would expect for a creek of its size. The fishes that are present are common species that are tolerant of disturbance. Although there has been environmental degradation, there is still a respectable amount of adequate habitat. We suspect part of the explanation for the low fish diversity is that past disturbances have eliminated some species, and they are unable to recolonize from other drainages because the Pilcher Park Dam acts as a barrier to dispersal. However, the Pilcher Park Dam also prevents the invasive Apollonia melanostoma Round Goby and Misgurnus anguillicaudatus Oriental Weatherfish from entering the watershed.

A more serious problem is water quality. Several wastewater treatment plants are located within the watershed. Although
Dorkin (1980) downplayed the role of pollution, we believe this issue should be revisited. The effects of nonpoint sources and wastewater treatment plants on water quality in Hickory Creek need to be examined. Even if water quality is satisfactory, it is unlikely that the fish assemblage would improve. Native fishes would have to be restocked because currently they are unable to bypass the Pilcher Park Dam. General development in the area is the overarching threat to Hickory Creek.

The spring-fed creeks in Pilcher Park hold an interesting assortment of fishes, most notably the darters Etheostoma nigrum and Etheostoma spectabile. These creeks provided habitat for Cottus bairdii Mottled Sculpin, but this species has not been seen in many years and may have been extirpated. Notropis heterolepis Blacknose Shiner (Illinois endangered species) was once present in Hickory Creek but is believed to have been extirpated when the small scattered wetlands were drained. Notropis heterodon Blackchin Shiner (Illinois threatened species) and Notropis anogenus Pugnose Shiner (Illinois endangered species) also have been reported in Hickory Creek, but we were unable to verify these records and believe they were misidentifications of $N$. heterolepis. Nocomis micropogon River Chub (Illinois endangered species) has been reported in Hickory Creek, but we were unable to verify this record and believe it was a misidentification of Noconis biguttatus Hornyhead Chub.

Jackson Creek - The diversity of fishes in Jackson Creek is above average. It is a relatively large drainage, with a variety of habitats and decent water quality. The stream possesses typical creek species and more unusual ones, like Erimyzon claviformis Western Creek Chubsucker, that prefer clean water and abundant native vegetation. This is the last surviving population of E. claviformis in Will County. The presence of Moxostoma duquesnei Black Redhorse, Moxostoma erythrurum Golden Redhorse, and Hypentelium nigricans Northern Hog Sucker is encouraging because these species require clean gravel and sand and a steady, reliable flow of water to feed and spawn. The presence of Carpiodes cyprinus Quillback, Ictiobus bubalus Smallmouth Buffalo, and Notropis hudsonius Spottail Shiner indicates that there is direct communication with the Des Plaines River and opportunities for faunal exchange. We hope the future of Jackson Creek does not repeat what we have seen in the history of nearby Hickory Creek.

KankakeE River Drainage-Exline Slough-Unlike other creeks, it has large populations of Aphredoderus sayanus Pirate Perch and Etheostoma microperca Least Darter. These two species prefer habitats with dense aquatic vegetation, which Exline Slough has in abundance. Esox americanus vermiculatus Grass Pickerel is also present and prefers a similar habitat, but it is more common than $A$. sayanus and $E$. microperca in the county. The other fishes are typical creek fishes. Judging from the fishes and the habitat, it is apparent that Exline Slough is a relict of the Kankakee Marsh. Agricultural practices and the ditching of prairie sloughs and creeks have changed the region over the past couple hundred years. Exline Slough gives us a glimpse into the past and provides habitat for fishes that were once more widespread and common in Will County.

Kankakee River-The habitat in the Will County portion of the river is predominantly clean rubble and gravel bottom with a moderate to swift current. This is ideal for redhorses, large catfishes, and smallmouth bass, all of which are abundant. The Will County stretch of the Kankakee River holds one of the largest populations of Moxostoma carinatum River 
Redhorse (Illinois threatened species) and Hybopsis annis Pallid Shiner (Illinois endangered species) in Illinois. There is an abundance of game fishes for recreational anglers. Notropis boops Bigeyed Shiner (Illinois endangered species), Notropis texanus Weed Shiner (Illinois endangered species), and Notropis chalybaeus Ironcolor Shiner (Illinois threatened species) disperse into the Will County portion of the Kankakee River from populations in adjacent counties. The diversity of fishes in the Kankakee River is well above average.

Prairie Creek-The diversity of fishes is above average. An apparently stable population of Noturlls exilis Slender Madtom is worth noting because it is one of only two populations in Will County. Moxostoma erythrirum are present upstream of Kemery Lake Dam. This redhorse requires clean gravel and sand and a steady, reliable flow of water to feed and spawn. Its presence upstream of the Kemery Lake Dam indicates low sedimentation and little habitat degradation.

UnNatural Waterways - Illinois and Michigan CanalDespite the degraded condition, an above-average number of species can be found in the Illinois and Michigan Canal. However, these species are of the hardy, widespread variety or ones found in degraded habitats. Environmentally sensitive species are absent. The historical importance of the Illinois and Michigan Canal is that it was the first permanent connection between the Great Lakes drainage and the Mississippi drainage since the Chicago Outlet dried approximately 4.000 years ago. This connection has since been broken.

Chicago Sanitary and Ship Canal-The invasive Cyprinus carpio Common Carp and Carassius auratus Goldfish dominate the biomass of the canal. The Chicago Sanitary and Ship Canal is in a critical biogeographic position. Historically, fishes could move between the Great Lakes drainage and Mississippi drainage only through seasonally flooded wetlands. The completion of the canal created a permanent connection between these two drainages. To prevent the movement of fishes, principally invasive species like Apollonia melanostoma Round Goby, Hypophthalmichthys molitrix Silver Carp, and Hypophthalmichthys nobilis Bighead Carp, between the Great Lakes and Mississippi, an electric barrier has been constructed across the canal near Romeoville. A second barrier is being constructed near the first barrier. It is unclear how effective these barriers will be at preventing the future spread of invasive species.

\section{Concluding Remarks}

There are 112 species in 23 families recorded from within the boundaries of Will County. Eleven species are introduced or nonnative, and 101 are native. In our opinion, the greatest threat to the fishes of Will County is the continual development spreading out from Chicago. Increased development brings increased erosion, nutrification, pollution, channelization, and impoundments. Maintaining riparian vegetation, allowing creeks to meander naturally, and proper treatment of wastewater will help ease the damage caused by urbanization. Past agricultural practices (channelization, draining wetlands, erosion, pesticides) have already degraded a number of aquatic habitats. Erosion in existing agricultural areas can be significant, but riparian buffers go a long way in reducing this problem. These issues need to be addressed if we are to properly conserve and manage the biodiversity of fishes in Will County.

\section{Acknowledgments}

We gratefully acknowledge Dave Mauger, Rebecca Key, and David Robson from the Forest Preserve District of Will County for providing permits, information, copies of reports, and financial assistance. Gratitude for field collection assistance and specimen processing is imparted to Tom Anton, Chris Jones, Ian Glasspool, Eric Brossman, Eric Hilton, and N. Jolynn Willink from The Field Museum of Natural History; Melvin McLaurin from the U.S. Army Corps of Engineers; Cathy Starr; and Ralph Steinberg. We thank Brooks Burr and Jeff Stewart from Southern Illinois University-Carbondale, Michael Retzer from the Illinois Natural History Survey, and Stephen Pescitelli and Robert Rung from Illinois Department of Natural Resources for providing historical data. We also thank Mike Rizzo and Renee Thakali from Midewin National Tallgrass Prairie, John Mendelson from Governors State University, Mary Pat Holtschlager, and Steven Markulin. We finally thank J. D. Ennis for GIS support. Lawrence Page, Michael Retzer, and Janet Voight provided constructive reviews.

\section{Literature Cited}

Bland, J. 1976. Hickory Creek revisited. Field Museum of Natural History Bulletin, January, 8-10, 18-21.

Bowman, D. 2005. Freckled madtom a big catch. Chicago Sun-Times, June 22.

Brooks, K. N., P. F. Ffolliott, H. M. Gregersen, and J. L. Thames. 1991. Hydrology and the Management of Watersheds. Iowa State University Press, Ames.

Bruner, J. C., ANd A. Resetar. 2001. Fishes of Hickory Creek basin, Des Plaines River Drainage, Illinois, USA: History, politics, climate, and the need for voucher specimens, p. 54. In American Society of Ichthyologist and Herpetologists 81st Annual Meeting. Program and Abstracts. Pennsylvania State University, College Station.

Burr, B. M., V. J. Santuccl, M. E. Roberts, A. M. Davis, and M. R. WhiLEs. 2005. Conservation Status and Life History Characteristics of the Blacknose Shiner, Notropis heterolepis (Cyprinidae), and Blackchin Shiner, Notropis heterodou (Cyprinidae), with Conservation Evaluations of the Pugnose Shiner, Notropis anogenus (Cyprinidae), and Banded Killifish, Fundulus diaphanus (Fundulidae). in Illinois. Max McGraw Wildlife Foundation, Dundee, Illinois.

Charlebois, P. M., J. E. Marsden, R. G. Goettel, R. K. Wolfe, D. J. Jude, AND S. Rudnika. 1997. The round goby, Neogobius melanostomus (Pallas): A review of European and North American literature. Illinois Natural History Survey Special Publication Number 20, Champaign.

CHIPPS, S. R., AND D. H. WAHL. 2004. Development and evaluation of a western mosquitofish bioenergetics model. Transactions of the American Fisheries Society, 133: 1150-1162.

Cole, L. J. 1905. The German carp in the United States, pp. 523-641. Appendix to the Report of the Commissioner of Fisheries to the Secretary of Commerce and Labor for the Year Ending June 30, 1904.

Courtenay, W. R., and G. K. Meffe. 1989. Small fishes in strange places: A review of introduced poeciliids, pp. 319-331. In Meffe, G. K. and F. F. Snelson, eds., Ecology and Evolution of Live Bearing Fishes (Poeciliidae). Prentice Hall. Englewood Cliffs, New Jersey. 
Dennison, S. G. 1978. Fish Survey of Northeastern Illinois Streams. The Metropolitan Sanitary District of Greater Chicago, Chicago.

DoRK1N, J. L., JR. 1980. The fishes of Hickory Creek. Master's thesis, University of Illinois at Chicago.

Dowling, T. E., AND W. R. HoEH. 1991. The extent of introgression outside the contact zone between Notropis cormitus and Notropis chrysocephalus (Teleostei: Cyprinidae). Evolution, 45: 944-956.

Etnier, D. A., and W. C. Starnes. 1993. The Fishes of Tennessee. University of Tennessee Press, Knoxville.

Frank1e, W. T., and R. S. Nelson. 2003. Guide to the Geology of the Joliet Area Including the Midewin National Tallgrass Prairie and the Des Plaines and MazonialBraidwood State Fish and Wildlife Areas, Will and Portions of Grundy and Kankakee Counties, Illinois. Illinois State Geological Survey, Champaign.

Greenberg, J. 2002. A Natural History of the Chicago Region. University of Chicago Press, Chicago.

. 2003. Current Events: The Lessons of Hickory Creek. Center for Neighborhood Technology and the Gaylord and Dorothy Donnelley Foundation, Chicago.

HiLl, L. 2000. The Chicago River: A Natural and Unnatural History. Lake Claremont Press, Chicago.

Hudbis, C. L., AND K. F. LAGLER. 2004. Fishes of the Great Lakes Region. Revised by G. R. Smith. University of Miehigan Press, Ann Arbor.

JANSEN, J., AND D. J. JUDE. 2001. Recruitment failure of mottied sculpin Cottus bairdi in Calumet Harbor, southern Lake Michigan, induced by the newly introduced round goby Neogobius melanostomus. Journal of Great Lakes Research, 27: 263-266.

Jenkins, R. E., AND N. M. Burkhead. 1994. Freshwater Fishes of Virginia. American Fisheries Society, Bethesda, Maryland.

Kolar, C. S., D. C. Chapman, W. R. Courtenay, Jr., C. M. Housel, J. D. Williams, And D. P. Jennings. 2007. Bighead Carps: A Biological Synopsis and Environmental Risk Assessment. American Fisheries Society Special Publication 33, Bethesda, Maryland.

LAiRd, C. A., AND L. M. PAGE. 1996. Non-native fishes inhabiting the streams and lakes of Illinois. Illinois Natural History Survey Bulletin, 35: 1-51.

Leslie, K. 1989. Changes in fish fauna on Plum Creek over a nine year period. Undergraduate thesis, Governors State University, University Park, Illinois.

MeEk, S. E., ANd S. F. Hildebrand. 1910. A synoptic list of the fishes known to occur within fifty miles of Chicago. Field Museum of Natural History Publication, Zoology Series, 7: 223-338.

Mrller. 1998. 1997 fish population survey report for Monee Reservoir. Illinois Department of Natural Resources, Division of Fisheries, Springfield.

1999. 1998 fish population survey report for Monee Reservoir. Illinois Department of Natural Resources, Division of Fisheries, Springfield.

- 2000. 1999 fish population survey report for Monee Reservoir. Illinois Department of Natural Resources, Division of Fisheries, Springfield.

2002. 2001 fish population survey report for Monee Reservoir. Illinois Department of Natural Resources, Division of Fisheries, Springfield.

2004. 2003 fish population survey report for Monee Reservoir. Illinois Department of Natural Resources, Division of Fisheries, Springfield.

Molling, D. A., AND J. L. CASEY. 1975. A study of the animal communities in Hickory Creek eompared to an original study of Victor E. Shelford in 1937, with emphasis on the causes and effects of enrichment. Master's thesis, Saint Mary's College, Winona, Minnesota.

Nelson, E. W. 1876. A partial catalogue of the fishes of Illinois. Illinois Museum of Natural History Bulletin, 1: 33-56.
1878. Report of the Commissioner for 1875-1876: Part IV: Fisheries of Chicago and vicinity, pp. 783-800. United States Commission of Fish and Fisheries, Washington D.C.

OKadA, Y. 1960. Studies on the freshwater fishes of Japan. II. Special part. Journal of the Faculty of Fisheries, Prefectural University of Mie, 4: 267-588.

Page, L. M., AND B. M. Burr. 1991. A field guide to freshwater fishes of North America north of Mexico. Peterson Field Guide Series No. 42. Houghton Mifflin Company, Boston.

PArker, D. 2006. Science reacquaints Chicago Wilderness with freckled madtom. Chicago Wilderness Magazine, Fall, 43.

RETZER, M. E. 2005. Changes in the diversity of native fishes in seven basins in Illinois, USA. American Midland Naturalist, 153: 128--141.

Retzer, M. E., ANd B. BAtTen. 2005. Fishes of the Chicago Region: A review of the Dennison and Illinois Natural History Survey Collections. Transactions of the Illinois State Academy of Science, 98: 63-73.

Retzer, M. E., And C. R. KowaliK. 2002. Recent changes in the distribution of river redhorse (Moxostoma carinatum) and greater redhorse (Moxostoma valenciennesi) (Cypriniformes: Catostomidae) in Illinois and comments on their nature history. Transactions of the Illinois State Academy of Science, 95: 327-333.

RunG, R. 1996. 1995 fish population survey report for Monee Reservoir. Illinois Department of Natural Resources, Division of Fisheries, Springfield.

1997. 1996 fish population survey report for Monee Reservoir. Illinois Department of Natural Resources, Division of Fisheries, Springfield.

Rung, R. C., And S. M. Pescitelli. 2007. Status of fish communities and stream quality in Prairie Creek and Grant Creek watersheds, August 2005. Illinois Department of Natural Resources, Division of Fisheries, Springfield.

Savitz, J., C. Aiello, and C. L. Bardygula. 1989. The first reeord of the white perch (Morone americana) in Illinois waters of Lake Michigan. Transactions of the Illinois Academy of Science, 82: $57-58$.

Shelford, V. E. 1911. Ecological succession, I. Stream fishes and the method of physiographic analysis. Biological Bulletin, 21: 9-35.

. 1913. Animal Communities in Temperate America: As Illustrated in the Chicago Region, A Study in Animal Ecology. The Geographic Society of Chicago Bulletin No. 5. University of Chicago Press, Chicago.

SMrth, P. W. 1979. The Fishes of Illinois. Illinois Natural History Survey, University of Illinois Press, Urbana.

Sullivan, J. 2003. Chicago Wilderness: An Atlas of Biodiversity Chicago Region Biodiversity Council, Chieago.

Trautman, M. B. 1957. The Fishes of Ohio. Ohio State University Press, Columbus.

WigGERs, R. 1997. Geology Underfoot in Illinois. Mountain Press Publishing Company, Missoula, Missouri.

WiLlink, P. W. 2002. Function and variation of gill rakers in the fish family Catostomidae, with comments on phylogenetic tests of natural selection. PhD dissertation, University of Michigan, Ann Arbor.

Willink, P. W., F. M. Verald1, AND J. B. LADONSK1. 2006 Rediscovery of the freckled madtom Noturus nocturnus Jordan \& Gilbert in the Des Plaines River, Illinois. Transactions of the Illinois Academy of Science, 99: 169-173.

Willman, H. B. 1971. Summary of the geology of the Chicago area. Illinois State Geological Survey Circular, 460: 1-77.

Woods, L. P. 1959. A survey of fishes in an Illinois stream. Chicago Natural History Museum Bulletin, January, 6-7.

__. 1960. The alewife. Chicago Natural History Museum Bulletin, 31: 6-8. 


\begin{tabular}{|c|c|c|}
\hline Family and species name & Common name & Endangered/threatened/invasive \\
\hline Lepisosteidae & Gars & \\
\hline Lepisosteus osseus & Longnose Gar & \\
\hline Lepisosteus platostomus & Shortnose Gar & \\
\hline Amiidae & Bowfins & \\
\hline Amia calva & Bowfin & \\
\hline Hiodontidae & Mooneyes & \\
\hline Hiodon alosoides & Goldeye & \\
\hline Hiodon tergisus & Mooneye & \\
\hline Clupeidae & Herrings and shads & \\
\hline Alosa chrysochloris & Skipjack Herring & \\
\hline Dorosoma cepedianum & Gizzard Shad & \\
\hline Dorosoma petenense & Threadfin Shad & Invasive \\
\hline Cyprinidae & Carps and minnows & \\
\hline Campostoma anomalum & Central Stoneroller & \\
\hline Campostoma oligolepis & Largescale Stoneroller & \\
\hline Carassius auratus & Goldfish & Invasive \\
\hline Cyprinella lutrensis & Red Shiner & \\
\hline Cyprinella spiloptera & Spotfin Shiner & \\
\hline Cyprinus carpio & Common Carp & Invasive \\
\hline Hybopsis amnis & Pallid Shiner & Endangered \\
\hline Hypoplutlaalmichtlyys molitrix & Silver Carp & Invasive \\
\hline Hypophthalmichthys nobilis & Bighead Carp & Invasive \\
\hline Luxilus chrysoceplaalus & Striped Shiner & \\
\hline Luxilus cornutus & Common Shiner & \\
\hline Lythrurus umbratilis & Redfin Shiner & \\
\hline Noconis biguttatus & Hornyhead Chub & \\
\hline Notemigonus crysoleucas & Golden Shiner & \\
\hline Notropis atherinoides & Emerald Shiner & \\
\hline Notropis blennius & River Shiner & \\
\hline Notropis boops & Bigeyed Shiner & Endangered \\
\hline Notropis buccatus & Silverjaw Minnow & \\
\hline Notropis buchanani & Ghost Shiner & \\
\hline Notropis clialybaeus & Ironcolor Shiner & Threatened \\
\hline Notropis dorsalis & Bigmouth Shiner & \\
\hline Notropis heterolepis & Blacknose Shiner & Endangered \\
\hline Notropis hudsonius & Spottail Shiner & \\
\hline Notropis rubellus & Rosyface Shiner & \\
\hline Notropis stramineus & Sand Shiner & \\
\hline Notropis texanus & Weed Shiner & Endangered \\
\hline Notropis volucellus & Mimic Shiner & \\
\hline Opsopoeodus emiliae & Pugnose Minnow & \\
\hline Phenacobius mirabilis & Suckermouth Minnow & \\
\hline Phoxinus erythrogaster & Southern Redbelly Dace & \\
\hline Pimephales notatus & Bluntnose Minnow & \\
\hline Pimepliales promelas & Fathead Minnow & \\
\hline Pimepluales vigilax & Bullhead Minnow & \\
\hline Rhinichtly's atratulus & Blacknose Dace & \\
\hline Scardinius erythrophthalmus & Rudd & Invasive \\
\hline Semotilus atromaculatus & Creek Chub & \\
\hline Cobitidae & Loaches & \\
\hline Misgurnus anguillicaudatus & Oriental Weatherfish & Invasive \\
\hline Catostomidae & Suckers & \\
\hline Carpiodes carpio & River Carpsucker & \\
\hline Carpiodes cyprinus & Quillback & \\
\hline Carpiodes velifer & Highfin Carpsucker & \\
\hline Catostomus commersonii & White Sucker & \\
\hline Erimyzon claviformis & Western Creek Chubsucker & \\
\hline Hypentelium nigricans & Northern Hog Sucker & \\
\hline Ictiobus bubalus & Smallmouth Buffalo & \\
\hline Ictiobus cyprinellus & Bigmouth Buffalo & \\
\hline Ictiobus niger & Black Buffalo & \\
\hline Minytrema melanops & Spotted Sucker & \\
\hline Moxostoma anisurum & Silver Redhorse & \\
\hline Moxostonia carinatum & River Redhorse & Threatened \\
\hline Moxostoma duquesnei & Black Redhorse & \\
\hline Moxostoma erythrurum & Golden Redhorse & \\
\hline Moxostoma macrolepidotum & Shorthead Redhorse & \\
\hline Ictaluridae & Bullhead catfishes & \\
\hline Ameiurus melas & Black Bullhead & \\
\hline Ameiurus natalis & Yellow Bullhead & \\
\hline Ameiurus nebulosus & Brown Bullhead & \\
\hline Ictalurus punctatus & Channel Catfish & \\
\hline
\end{tabular}


Appendix. Continued.

\begin{tabular}{|c|c|c|}
\hline Family and species name & Common name & Endangered/threatened/invasive \\
\hline Noturus exilis & Slender Madtom & \\
\hline Noturus flavus & Stonecat & \\
\hline Noturus gyrinus & Tadpole Madtom & \\
\hline Noturus nocturnus & Freckled Madtom & \\
\hline Pylodictis olivaris & Flathead Catfish & \\
\hline Esocidae & Pikes & \\
\hline Esox americanus vermiculatus & Grass Pickerel & \\
\hline Esox lucins & Northern Pike & \\
\hline Umbridae & Mudminnows & \\
\hline Umbra limi & Central Mudminnow & \\
\hline Salmonidae & Salmons & \\
\hline Oncorlyynchus mykiss & Rainbow Trout & Invasive \\
\hline Percopsidae & Trout-perches & \\
\hline Percopsis omiscomaycus & Trout-Perch & \\
\hline Aphredoderidae & Pirate perch & \\
\hline Apliredoderus sayanus & Pirate Perch & \\
\hline Fundulidae & Killifishes & \\
\hline Fundulus dispar & Starhead Topminnow & Threatened \\
\hline Fundulus notatus & Blackstripe Topminnow & \\
\hline Poeciliidae & Livebearers & \\
\hline Gambusia affinis & Mosquito Fish & \\
\hline Atherinopsidae & Silversides & \\
\hline Labidestles sicculus & Brook Silverside & \\
\hline Gasterosteidae & Sticklebacks & \\
\hline Gasterosteus aculeatus & Threespine Stickleback & Invasive \\
\hline Cottidae & Sculpins & \\
\hline Cottus bairdii & Mottled Sculpin & \\
\hline Moronidae & Striped basses & \\
\hline Morone americana & White Perch & Invasive \\
\hline Morone chrysops & White Bass & \\
\hline Morone mississippiensis & Yellow Bass & \\
\hline Centrarchidae & Sunfishes and basses & \\
\hline Ambloplites rupestris & Rockbass & \\
\hline Lepomis cyanellus & Green Sunfish & \\
\hline Lepomis gibbosus & Pumpkinseed & \\
\hline Lepomis gulosus & Warmouth & \\
\hline Lepomis humilis & Orangespotted Sunfish & \\
\hline Lepomis macrochirus & Bluegill & \\
\hline Lepomis microlophus & Redear Sunfish & Invasive \\
\hline Lepomis peltastes & Northern Longear Sunfish & \\
\hline Micropterus dolomieu & Smallmouth Bass & \\
\hline Micropterus salmoides & Largemouth Bass & \\
\hline Ponoxis anmularis & White Crappie & \\
\hline Pomoxis nigromaculatus & Black Crappie & \\
\hline Percidae & Perches and darters & \\
\hline Ammocrypta clara & Western Sand Darter & Endangered \\
\hline Etheostoma caeruleum & Rainbow Darter & \\
\hline Etheostoma exile & Iowa Darter & Threatened \\
\hline Etheostoma flabellare & Fantail Darter & \\
\hline Etheostona microperca & Least Darter & \\
\hline Etheostoma nigrum & Johnny Darter & \\
\hline Etheostoma spectabile & Orangethroat Darter & \\
\hline Etheostoma zonale & Banded Darter & \\
\hline Perca flavescens & Yellow Perch & \\
\hline Percina caprodes & Logperch & \\
\hline Percina maculata & Blackside Darter & \\
\hline Percina plioxocephala & Slenderhead Darter & \\
\hline Sander canadensis & Sauger & \\
\hline Sander vitreus & Walleye & \\
\hline Sciaenidae & Drums & \\
\hline Aplodinotus grunniens & Freshwater Drum & \\
\hline Gobiidae & Gobies & \\
\hline Apollonia melanostoma & Round Goby & Invasive \\
\hline
\end{tabular}




Field Museum of Natural History

1400 South Lake Shore Drive Chicago, Illinois 60605-2496

Telephone: (312) 665-7769 